\title{
Phylogenetic relationships and morphological reappraisal of Chaetothyriales
}

\author{
Tian $\mathbf{Q}^{1,2}$, Chomnunti $\mathrm{P}^{1,2}$, Lumyong $\mathrm{S}^{3}$, Liu $\mathrm{JK}^{4}$ and Hyde $\mathrm{KD}^{1,3,5}$ \\ ${ }^{1}$ Center of Excellence in Fungal Research, Mae Fah Luang University, Chiang Rai 57100, Thailand \\ ${ }^{2}$ School of Science, Mae Fah Luang University, Chiang Rai 57100, Thailand \\ ${ }^{3}$ Research Center of Microbial Diversity and Sustainable Utilization, Chiang Mai University, Chiang Mai 50200, \\ Thailand \\ ${ }^{4}$ School of Life Science and Technology, Center for Informational Biology, University of Electronic Science and \\ Technology of China, Chengdu 611731, People's Republic of China \\ ${ }^{5}$ Innovative Institute of Plant Health, Zhongkai University of Agriculture and Engineering, Haizhu District, \\ Guangzhou, Guangdong 510225, People's Republic of China
}

Tian Q, Chomnunti P, Lumyong S, Liu JK, Hyde KD 2021 - Phylogenetic relationships and morphological reappraisal of Chaetothyriales. Mycosphere 12(1), 1157-1261, Doi 10.5943/mycosphere/12/1/15

\begin{abstract}
The order Chaetothyriales, are mainly epiphytes, often with the appearance of sooty moulds and are found adpressed to the surface of leaves and stems, gaining nutrients from sugary exudates. Others can be saprobes growing on decaying wood or pathogens on plants, mushrooms and animals, including humans. This group has other ecologies, such as being associated with ants, rocks and lichens. Most species of Chaetothyriales are delimited exclusively by morphology. There has been very little molecular reassessment of the group. We revisit the recently listed genera in Chaetothyriales as in the Outline of the Fungi 2020. Currently, the families, Chaetothyriaceae, Coccodiniaceae, Cyphellophoraceae, Epibryaceae, Herpotrichiellaceae, Lyrommataceae, Microtheliopsidaceae, Paracladophialophoraceae, Pyrenotrichaceae and Trichomeriaceae, with 55 genera are accepted in Chaetothyriales. Four genera have not been resolved and are placed in Chaetothyriales genera incertae sedis. A checklist and a backbone tree of Chaetothyriales based on ITS and LSU sequence data are provided. Illustrations, line drawings, and descriptions are provided based on the examination of types and the literature.
\end{abstract}

Key words - Checklist - Phylogeny - Revision - Taxonomy - Types

\section{Introduction}

Chaetothyriales M.E. Barr was introduced by Barr (1987) and is characterized by erumpent to superficial ascomata with periphysate ostioles formed on a subiculum (Kirk et al. 2008). The unique character of this group is bitunicate asci with an ocular thickening in the apical region. They share similarities characteristic of bitunicate asci with taxa in Dothideomycetes O.E. Erikss. \& Winka, and thus, Eriksson (1982), placed Chaetothyriaceae Hansf. ex M.E. Barr with Herpotrichiellaceae Munk in Dothideales Lindau. Barr (1987) placed Chaetothyriaceae in Chaetothyriales and incorporated eight families. However, the relationships of poorly studied Chaetothyriaceae in the order is unclear due to lack of molecular data. Phylogenetically, Chaetothyriales is closely related to Eurotiales and was therefore transferred to Eurotiomycetes O.E. Erikss. \& Winka (Spatafora et al. 1995, Berbee 1996, Winka et al. 1998, Haase et al. 1999). The taxonomic placement of Chaetothyriales has been confirmed 
in recent molecular studies (Lutzoni et al. 2004, Miadlikowska \& Lutzoni 2004, Reeb et al. 2004, Schoch et al. 2006, Chen et al. 2015, Liu et al. 2015, Quan et al. 2020).

Chaetothyriales, presently comprises Chaetothyriaceae Hansf. ex M.E. Barr, Coccodiniaceae Höhn. ex O.E. Erikss., Cyphellophoraceae Réblová \& Unter., Epibryaceae S. Stenroos \& Gueidan, Herpotrichiellaceae Munk, Lyrommataceae Lücking, Microtheliopsidaceae O.E. Erikss., Paracladophialophoraceae Crous, Pyrenotrichaceae Zahlbr. and Trichomeriaceae Chomnunti \& K.D. Hyde (Geiser et al. 2006, Kirk et al. 2008, Chomnunti et al. 2012a, 2014, Flakus \& Farkas 2013, Réblová et al. 2013, Gueidan et al. 2014, Wijayawardene et al. 2020). The inclusion of Herpotrichiellaceae was clarified by Haase et al. (1999), while Cladophialophora Borelli is unclear, despite having similar, long coherent, conidial chains. Chaetothyriaceae is also poorly understood since genera in this family have rarely been investigated (Winka et al. 1998, Liu \& Hall 2004, Lumbsch et al. 2005, Badali et al. 2008, Gueidan et al. 2008, Chomnunti et al. 2012b). Collections of Trichomeriaceae from Thailand revealed a monophyletic group of foliar epiphytes, similar to sooty molds, confirming their placement within Chaetothyriales (Chomnunti et al. 2012a). Recent phylogenetic delimitations of Trichomeriaceae resulted in many paraphyletic, undetermined taxa. We therefore, broaden the delimitation of the family to comprise taxa of Bradymyces Hubka et al., Knufia L.J. Hutchison \& Unter., and Metulocladosporiella Crous et al. (Crous et al. 2006, Tsuneda et al. 2011, Hubka et al. 2014). Epibryaceae with a single genus is thought to be phylogenetically distinct from other families in Chaetothyriales (Réblová et al. 2013, Gueidan et al. 2014).

Ecological habitats of species of Chaetothyriales are highly diverse. Typically, Chaetothyriaceae, Coccodiniaceae, Trichomeriaceae are epiphytes having the appearance of sooty moulds and mostly grow on the surface of living leaves, apparently gaining nutrients from sugary exudates of insects in the Order Hemitera (Barr 1987, Chomnunti et al. 2014). Species are characterized by dark mycelium adpressed to the surface of leaves and stems, but not penetrating the host tissues (Batista \& Ciferri 1962, 1963, Eriksson 1981, Chomnunti et al. 2012a, 2014). Species of Cyphellophoraceae are known from individual reports from plants, but are mostly endophytes on plants and animals, including human pathogens (Vries 1962, de Hoog et al. 1999, 2000, Lopez et al. 2007, Li et al. 2011, Feng et al. 2012, Gao et al. 2015, Yang et al. 2018, Phookamsak et al. 2019, Rashmi et al. 2019, Vu et al. 2019). Inconspicuous immersed mycelium is found in the asexual morphs of Herpotrichiellaceae which mostly grow on decayed wood or mushrooms (Barr 1987, Untereiner \& Naveau 1999, Untereiner 2000, Sun et al. 2019). Both sexual and asexual morphs of Herpotrichiellaceae have been reported, while most of the asexual morphs are opportunistic animal or human pathogens (Haase et al. 1999, Prenafeta-Boldú et al. 2006, Crous et al. 2007, Réblová et al. 2013). However, this group also occupies other habitats, such as being symbiotic ant-associated (Little \& Currie 2007, Defossez et al. 2009, Mayer \& Voglmayr 2009, Untereiner et al. 2011, Nepel et al. 2014), lichenicolous (Untereiner et al. 2011, Diederich et al. 2013) and rock-inhabiting (Sterflinger et al. 1999, Ruibal et al. 2005, 2008, Gueidan et al. 2008). Species in Epibryaceae include saprobes on plants and biotrophic parasites of algae, mosses, or asymptomatic on lichens (Döbbeler 1978, U'Ren et al. 2010, Gueidan et al. 2014, Döbbeler, 2016, Muggia et al. 2016, Darmostuk \& Khodosovtsev 2019). Members of Lyrommataceae, Microtheliopsidaceae and Pyrenotrichaceae are known as lichenicolous fungi (Riddle 1917, Engler \& Prantl 1926, Eriksson 1981, 2006, Eriksson et al. 2004, Herrera-Campos et al. 2005, Lücking 2008, Flakus \& Farkas 2013) Members of Trichomeriaceae are mostly rock colonizers or epiphytes as sooty moulds on plants (Chomnunti et al. 2012a, 2014, Zakharova et al. 2013).

Species of Chaetothyriales are exclusively delimited by morphology and have generally not been reassessed using molecular data and are normally highly homoplastic (Staiger 2002, Miller \& Huhndorf 2004, 2005). Therefore, molecular data is needed to verify their natural classification.

The life cycles of taxa of Chaetothyriaceae, Coccodiniaceae and Trichomeriaceae are similar to sooty moulds. Spores are usually spread by wind or raindrops and insects probably serve as vectors (Nelson 2008, He et al. 2013). After germination on honeydew, the mycelium grows on the surface (Hughes 1976, Reynolds 1999, Nelson 2008). Colonies develop and often amass with the same or other species and form biofilms covering entire leaves or stems, even whole plants (Hughes 1983, Laemmlen 2011). Asexual morphs appear first, while sexual morphs may also develop in mature colonies. Asexual 
and sexual morphs may not appear at the same time, and only $70 \%$ were found to produce asexual states by Chomnunti et al. (2014).

This study aims to reappraise the placement of genera in Chaetothyriales based on phylogenetic analyses and morphological characteristics and provides a backbone tree for these taxa, as well as a checklist. This will enhance the future study of species in the group.

\section{Material \& Methods}

\section{Herbarium Examination}

Herbarium specimens, including type specimens, were loaned from B, BPI, BR, E, FH, G, GZU, H, HIRO, IMI, K, M, MA, NY, PC, PDD, S and W fungaria (see http://sweetgum.nybg.org/ih/index.php for full names). Ascomata were rehydrated in 5\% $\mathrm{KOH}$ and stained with cotton blue or India ink if necessary before examination. The cotton blue stain was used to verify the septation of ascospores and internal elements of the hamathecium. India ink was added to water mounts to visualize gelatinous sheaths and ascospore appendages. Permanent slides were prepared by mounting material in lactoglycerol and sealing the coverslips with clear nail polish. Fruiting bodies were examined with a stereomicroscope (Olympus SZH10), micromorphology was determined with a Nikon ECLIPSE 80i compound microscope and images were captured with a Canon EOS 600D digital camera. Measurements were made with Tarosoft (R) Image FrameWork version 0.9.7. Photographic plates were prepared in Adobe Photoshop version CS6 (Adobe Systems, The United States).

Terminologies mainly follow Ulloa \& Hanlin (2000) and Zhang et al. (2009, 2012). In addition, ascomata size is defined as small: $<300 \mu \mathrm{m}$ diam., medium: from $300 \mu \mathrm{m}$ to $600 \mu \mathrm{m}$ diam., large: $>600 \mu \mathrm{m}$ diam.

\section{Phylogenetic Analyses}

The taxa of Eurotiomycetes and alined strains used in the analyses were obtained from GenBank (Table 1). The multiple alignments were made by MAFFT v. 7.036 (Katoh \& Standley 2013) and adjusted manually for improvement where necessary using BioEdit v. 7.2 (Hall 1999) and ClustalX v. 1.83 (Thompson et al. 1997).

MODELTEST v. 2.0 (Nylander 2004) following Akaike Information Criterion was used to determine the best-fit model of evolution for each data set for Bayesian and Maximum likelihood analyses.

Maximum-likelihood (ML) analysis was performed in RAxML (Stamatakis 2008) implemented in raxmlGUI v.0.9b2 (Silvestro \& Michalak 2011). One thousand non-parametric bootstrap iterations were employed with the available models of generalized time-reversible (GTR model) and a discrete gamma distribution (Stamatakis et al. 2008, Liu et al. 2011). Maximum likelihood bootstrap values equal to or greater than $70 \%$ were given as the first set of numbers above the nodes.

A Bayesian analysis was conducted with MrBayes v. 3.1.2 (Huelsenbeck \& Ronqvist 2001) to evaluate Posterior probabilities (PP) (Rannala \& Yang 1996, Zhaxybayeva \& Gogarten 2002) by Markov Chain Monte Carlo sampling (BMCMC). Six simultaneous Markov chains were run for $1,000,000$ generations and trees were sampled every 100th generation and 10,000 trees were obtained. The first 2,000 trees, representing the burn-in phase of the analyses, were discarded, while the remaining 8,000 trees were used for calculating posterior probabilities in the majority rule consensus tree (critical value for the topological convergence diagnostic is 0.01) (Cai et al. 2006). Bayesian Posterior Probabilities (BYPP) equal to or greater than 0.90 were given below or above each node.

Table 1 Taxa used in the phylogenetic analysis and their corresponding GenBank numbers

\begin{tabular}{llrc}
\hline \multirow{2}{*}{ Species } & \multirow{2}{*}{ Voucher/Strain } & \multicolumn{2}{c}{ GenBank accession numbers } \\
\cline { 3 - 4 } & & LSU & \multicolumn{1}{c}{ ITS } \\
\hline 'Anthracinomyces petraeus' & CGMCC:3.17315 & KP174924 & KP174843 \\
Aculeata aquatica & MFLUCC 11-0529 & MG922575 & MG922571 \\
\hline
\end{tabular}


Table 1 Continued.

\begin{tabular}{|c|c|c|c|}
\hline \multirow{2}{*}{ Species } & \multirow{2}{*}{ Voucher/Strain } & \multicolumn{2}{|c|}{ GenBank accession numbers } \\
\hline & & LSU & ITS \\
\hline Adautomilanezia caesalpiniae & HUEFS 216632 & NG_058594 & NR_153560 \\
\hline Aequabiliella effusa & CBS 120883 & NG_056966 & NR_132005 \\
\hline Agonimia tristicula & Palice 5651 & AY3000828 & / \\
\hline Aleuria aurantia & AFTOL-ID 65 & AY544654 & DQ491495 \\
\hline Amaurascopsis perforata & FMR 388 & I & AJ390377 \\
\hline Amauroascus verrucosus & CBS 181.70 & MH871325 & MH859546 \\
\hline Anthopsis catenata & CBS 492.81 & MF479749 & MH861371 \\
\hline Anthopsis deltoidea & CBS 263.77 & KX447683 & KX447684 \\
\hline Anthracocarpon virescens & M. Prieto 530 & GU228948 & l \\
\hline Anthracothecium nanum & AFTOL-ID 1649 & FJ358271 & KT232207 \\
\hline Anzia colpodes & Lumbsch 4.VI.04 & DQ923651 & DQ980000 \\
\hline Aphanoascus mephitalis & ATCC 22144 & NG_056949 & NR_154665 \\
\hline Aphanophora eugeniae & CBS 124105 & FJ839652 & FJ839617 \\
\hline Apinisia graminicola & CBS 721.68 & NG_056945 & I \\
\hline Apiospora bambusae & ICMP 6889 & DQ368630 & l \\
\hline Arachniotus ruber & CBS 352.90 & MH873901 & MH862216 \\
\hline Arachnomyces nitidus & IFO 32048 & $\mathrm{AB} 075351$ & / \\
\hline Arachnotheca glomerata & CBS 349.71 & MH871926 & MH860158 \\
\hline Armillaria mellea & AFTOL-ID 449 & AY700194 & AY789081 \\
\hline Arthrocladium caudatum & CBS 457.67 & KT337443 & MH859032 \\
\hline Arthroderma curreyi & CBS 353.66 & MH870459 & MH858822 \\
\hline Arthrophiala arthrospora & CPC 19480 & KX447144 & KY173474 \\
\hline Arthropsis cirrhata & CBS 628.83 & HG004549 & I \\
\hline Arthropsis hispanica & UTHSC 10-2389 & HE965763 & HE965762 \\
\hline Arthropsis truncata & CBS 584.82 & NG_056973 & NR_159641 \\
\hline Ascobolus crenulatus & AFTOL-ID 181 & AY 544678 & DQ491504 \\
\hline Ascocalvatia alveolata & ATCC 22147 & NG_056946 & 1 \\
\hline Ascocoryne sarcoides & AFTOL-ID 1834 & FJ176886 & l \\
\hline Ascodesmis sphaerospora & AFTOL-ID 920 & FJ176858 & l \\
\hline Ascosphaera apis & CBS 402.96 & l & MH862580 \\
\hline Aspergillus bisporus & NRRL 3693 & NG_057328 & NR_135377 \\
\hline Aspergillus nidulans & NRRL 187 & EF652427 & EF652427 \\
\hline Aspicilia caesiocinerea & AFTOL-ID 653 & DQ986778 & HQ650636 \\
\hline Atla alpina & SS193 & EU697732 & EU697725 \\
\hline Atrokylindriopsis setulosa & HMAS245592 & KP337329 & KP337330 \\
\hline Auxarthron californiense & ATCC 15600 & NG_056947 & NR_121259 \\
\hline Auxarthronopsis bandhavgarhensis & NFCCI 2185 & NG_057012 & NR_153515 \\
\hline Baeomyces placophyllus & $\mathrm{T} 1364$ & KU844631 & KU844777 \\
\hline Bagliettoa limborioides & CG1750 & l & KM371454 \\
\hline Bettsia fastidia & CBS 493.91 & MH873953 & MH862271 \\
\hline Blastomyces dermatitidis & CBS 673.68 & KT155306 & KT155961 \\
\hline Botryolepraria lesdainii & Spribille17964 & GU181264 & GU181263 \\
\hline Botrytis cinerea & AFTOL-ID 59 & AY544651 & DQ491491 \\
\hline Bradymyces oncorhynchi & CCF 4369 & HG426063 & NR_132843 \\
\hline Brunneocarpos banksiae & CPC 29841 & KX228352 & NR_147648 \\
\hline Brycekendrickomyces acaciae & CBS 124104 & FJ839641 & FJ839606 \\
\hline Buellia frigida & AFTOL-ID 889 & DQ883695 & HQ650628 \\
\hline Bulgaria inquinans & AFTOL-ID 916 & DQ470960 & 1 \\
\hline Byssoonygena ceratinophila & ATCC 64724 & NG_058608 & l \\
\hline Caliciopsis pinea & CBS 139.64 & DQ678097 & KP881691 \\
\hline Calicium salicinum & CBS 100898 & KF157982 & l \\
\hline Calicium viride & Soechting 7475 & AF356670 & / \\
\hline Calycina herbarum & KUS-F51458 & JN086693 & JN033390 \\
\hline Calyptrozyma arxii & CBS 354.92 & l & NR_137141 \\
\hline Camptophora hylomeconis & CBS 113311 & EU035415 & KC455241 \\
\hline Candelaria concolor & AFTOL-ID 1706 & DQ986791 & l \\
\hline Candelariella aurella & Hermansson 10056 & AY853361 & l \\
\hline
\end{tabular}


Table 1 Continued.

\begin{tabular}{|c|c|c|c|}
\hline \multirow{2}{*}{ Species } & \multirow{2}{*}{ Voucher/Strain } & \multicolumn{2}{|c|}{ GenBank accession numbers } \\
\hline & & LSU & ITS \\
\hline Canoparmelia caroliniana & AFTOL-ID 6 & AY584634 & DQ782833 \\
\hline Capnodium coffeae & CBS 147.52 & DQ247800 & MH856967 \\
\hline Capronia pilosella & AFTOL-ID 657 & DQ823099 & DQ826737 \\
\hline Castanedomyces australiensis & FMR 5484 & / & $\mathrm{AJ} 131785$ \\
\hline Catapyrenium cinereum & MA16301 & GQ344587 & GQ344598 \\
\hline Celerioriella dura & CBS 120882 & NG_058775 & NR_132004 \\
\hline Celothelium cinchonarum & F $17105 \mathrm{f}$ & DQ329020 & / \\
\hline Ceramothyrium ficus & MFLUCC 15-0228 & KT588599 & KT588601 \\
\hline Ceramothyrium thailandicum & MFLUCC 10-0008 & HQ895835 & HQ895838 \\
\hline Chaenotheca brachypoda & CBS 100900 & KF157983 & l \\
\hline Chaenotheca phaeocephala & CBS 100906 & KF157984 & l \\
\hline Chaenotheca trichialis & CBS 113986 & KF157985 & / \\
\hline Chaenotheca xyloxena & CBS 100907 & KF157986 & l \\
\hline Chaenothecopsis khayensis & H:JR 04G058 & HQ172895 & JX122785 \\
\hline Chaenothecopsis resinophila & H:JR 000424 & JX122782 & JX122780 \\
\hline Chaetomium globosum & AFTOL-ID 217 & AY545729 & DQ518179 \\
\hline Chaetothyriales sp. & Trii4 & KX822551 & KX822551 \\
\hline Chaetothyriales sp. & CBS 128963 & KX822328 & l \\
\hline Chaetothyriales sp. & CBS 128959 & KX822542 & KX822542 \\
\hline Chaetothyriales sp. & T9 & KF614780 & KF614780 \\
\hline Chaetothyriales sp. & CBS 128943 & KX822485 & KX822485 \\
\hline Chaetothyriales sp. & CBS 129047 & KX822533 & KX822533 \\
\hline Chaetothyriales sp. & A933 & KT270641 & l \\
\hline Chaetothyrium agathis & MFLUCC 12-0113 & KP744480 & KP744437 \\
\hline Cheilymenia stercorea & AFTOL-ID 148 & AY544661 & DQ491500 \\
\hline Chlamydosauromyces punctatus & UAMH 9990 & 1 & NR_165613 \\
\hline Chlorociboria aeruginosa & AFTOL-ID 151 & AY544669 & DQ491501 \\
\hline Chrysosporium echinulatum & CBS 141178 & MH878205 & 1 \\
\hline Chrysosporium submersum & CBS 101575 & MH874348 & KT155673 \\
\hline Cirrosporium novae-zelandiae & CBS 125236 & HQ878612 & l \\
\hline Cladophialophora carrionii & CBS 160.54 & NG_055741 & EU137266 \\
\hline Cladosporium herbarum & CBS 121621 & MH874676 & MH863124 \\
\hline Clavascidium umbrinum & AFTOL-ID 2274 & EF643749 & / \\
\hline Coccidioides immitis & CBS 120936 & MH874654 & MH863096 \\
\hline Coccodinium bartschii & CPC 13861 & EU019265 & EU019265 \\
\hline Cordyceps militaris & OSC 93623 & AY184966 & JN049825 \\
\hline Corynelia uberata & PREM 61207 & 1 & NR_153903 \\
\hline Ctenomyces serratus & CBS 187.61 & NG_058765 & NR_144890 \\
\hline Cudoniella clavus & AFTOL-ID 166 & DQ4̄70944 & DQ49 91502 \\
\hline Cylindroconidiis aquaticus & MFLUCC 11-0294 & MH236579 & MH236576 \\
\hline Cyphellophora guyanensis & CBS 129342 & $\mathrm{KC} 455253$ & KC455240 \\
\hline Cyphellophora laciniata & CBS 190.61 & FJ358239 & JQ766423 \\
\hline Cyphellophoriella pruni & CPC 25120 & l & KR611878 \\
\hline Dendrographa minor & AFTOL-ID 355 & AF279382 & DQ842015 \\
\hline Dermatocarpon miniatum & Sohrabi 4609 & KY773247 & KY697126 \\
\hline Dermea acerina & AFTOL-ID 941 & DQ247801 & AF141164 \\
\hline Diaporthe eres & AFTOL-ID 935 & AF408350 & DQ491514 \\
\hline Diatrype disciformis & AFTOL-ID 927 & DQ470964 & l \\
\hline Disciotis venosa & AFTOL-ID 179 & AY544667 & DQ491503 \\
\hline Dissoconium aciculare & CBS 204.89 & GU214419 & AY725520 \\
\hline Dolabra nepheliae & CBS 122120 & GU332517 & l \\
\hline Dothidea hippophaes & CBS 188.58 & DQ678048 & MH857750 \\
\hline Dothidea insculpta & CBS 189.58 & DQ247802 & AF027764 \\
\hline Dothiora cannabinae & AFTOL-ID 1359 & DQ470984 & l \\
\hline Elaphomyces aculeatus & IC10041103 & KX238880 & KX238844 \\
\hline Elaphomyces cyanosporus & LIP-0001137 & KX238874 & KX238826 \\
\hline Eleutherascus lectardii & AFTOL-ID 933 & DQ470966 & / \\
\hline Emergomyces pasteurianus & CBS 101426 & KT154983 & KT155671 \\
\hline
\end{tabular}


Table 1 Continued.

\begin{tabular}{|c|c|c|c|}
\hline \multirow{2}{*}{ Species } & \multirow{2}{*}{ Voucher/Strain } & \multicolumn{2}{|c|}{ GenBank accession numbers } \\
\hline & & LSU & ITS \\
\hline Emmonsia crescens & UAMH 3008 & l & NR_132795 \\
\hline Emmonsiellopsis terrestris & UAMH 2304 & / & NR_153965 \\
\hline Endocarpon pusillum & CG470 & l & KY769556 \\
\hline Endothia gyrosa & AFTOL-ID 1223 & DQ470972 & KT225530 \\
\hline Epibryon bryophilum & M2 & EU940090 & / \\
\hline Epibryon plagiochilae & M187 & EU940124 & l \\
\hline Epidermophyton floccosum & CBS 457.65 & MH870307 & MH858667 \\
\hline Eremascus albus & CBS 975.69 & FJ358283 & MH859498 \\
\hline Exophiala salmonis & CBS 157.67 & AY213702 & JF747137 \\
\hline Extremus antarcticus & CCFEE 451 & GU250360 & KF309978 \\
\hline Flakea papillata & AFTOL-ID 1041 & KT232216 & KT232210 \\
\hline Fonsecaea pedrosoi & CBS 271.37 & KJ930166 & AB114127 \\
\hline Fumagopsis stellae & CBS 145078 & NG_066293 & NR_161138 \\
\hline Geoglossum nigritum & AFTOL-ID 56 & AY 544650 & DQ4̄91490 \\
\hline Gnomonia gnomon & AFTOL-ID 952 & AF408361 & DQ491518 \\
\hline Granulopyrenis seawardii & CBS 109025 & EF411062 & 1 \\
\hline Guarromyces ceretanicus & CBS 269.89 & MF893224 & MF926403 \\
\hline Gymnascella aurantiaca & ATCC 22394 & AY176747 & HМ991267 \\
\hline Gymnoascus reesii & CBS 409.72 & MH872223 & MH860506 \\
\hline Gyromitra californica & AFTOL-ID 176 & AY544673 & / \\
\hline Hamigera avellanea & CBS 295.48 & l & NR_156333 \\
\hline Henrica melaspora & AA62248 & / & KY7̄69557 \\
\hline Heteroplacidium imbricatum & AFTOL-ID 2281 & EF643756 & l \\
\hline Histoplasma capsulatum & CBS 287.54 & MH868877 & MH857336 \\
\hline Hyaloscypha hepaticola & M339 & EU940150 & EU940226 \\
\hline Hydropunctaria maura & AMNH:LA31903 & KY773249 & KY697129 \\
\hline Involucropyrenium waltheri & JH59126 & KF959809 & KF959781 \\
\hline Knufia cryptophialidica & DAOM 216555 & JN040500 & JN040501 \\
\hline Kraurogymnocarpa trochleospora & CBS 591.71 & MH872035 & MH860277 \\
\hline Lacazia loboi & human skin & / & MN403304 \\
\hline Lachnum virgineum & AFTOL-ID 49 & AY544646 & DQ491485 \\
\hline Lagenulopsis bispora & PREM 57232 & NG_060325 & NR_154120 \\
\hline Lasallia pustulata & AFTOL-ID 554 & DQ 883690 & HM-̄161456 \\
\hline Lasiobolidium spirale & AFTOL-ID 1321 & FJ176873 & / \\
\hline Lasiosphaeria ovina & SMH4605 & AY436413 & AY587923 \\
\hline Lecanactis abietina & Ertz 5068 & AY548812 & AY548804 \\
\hline Lecidea fuscoatra & AFTOL-ID 589 & DQ912332 & HQ650707 \\
\hline Lecophagus sp & AFTOL-ID 183 & DQ273799 & AY997058 \\
\hline Leiothecium ellipsoideum & CBS 607.74 & FJ358285 & NR_144922 \\
\hline Leptoxyphium fumago & CBS 123.26 & MH866361 & MH854862 \\
\hline Letrouitia domingensis & AFTOL-ID 102 & AY584648 & HQ650700 \\
\hline Leucothecium emdenii & CBS 576.73 & NG_057812 & l \\
\hline Lichenodiplis lecanorae & $\mathrm{L}$ & KT2̌-85909 & l \\
\hline Lindra thalassiae & AFTOL-ID 413 & DQ470947 & DQ491508 \\
\hline Lithophila guttulata & CCFEE 5907 & KR781061 & KP791773 \\
\hline Lithothelium immersum & AA11919 & KT808556 & KT820111 \\
\hline Lobaria scrobiculata & AFTOL-ID 128 & AY584655 & AF524913 \\
\hline Lophophyton gallinae & CBS 244.66 & MH870427 & MH858789 \\
\hline Loramyces macrosporus & AFTOL-ID 913 & DQ470957 & / \\
\hline Lulworthia fucicola & ATCC 64288 & AY878965 & l \\
\hline Malbranchea pulchella & IFM 41308 & AB359426 & AB361638 \\
\hline Mallochia echinulata & CBS 168.73 & MH878316 & / \\
\hline Marcelleina persoonii & AFTOL-ID 164 & DQ470943 & l \\
\hline Marinophialophora garethjonesii & MFLUCC 16-1449 & KY305176 & NR_164246 \\
\hline Mastodia tessellata & Schultz 16853 & / & MN952977 \\
\hline Megalospora tuberculosa & AFTOL-ID 107 & AY584650 & HQ650701 \\
\hline Melanconis marginalis & AR3442 & AF408373 & 1 \\
\hline Melanoctona tectonae & MFLUCC 12-0389 & KX258779 & KX258778 \\
\hline
\end{tabular}


Table 1 Continued.

\begin{tabular}{|c|c|c|c|}
\hline \multirow{2}{*}{ Species } & \multirow{2}{*}{ Voucher/Strain } & \multicolumn{2}{|c|}{ GenBank accession numbers } \\
\hline & & LSU & ITS \\
\hline Melnikomyces vietnamensis & CBS 136209 & NG_058087 & NR_164227 \\
\hline Meria laricis & AFTOL-ID 907 & DQ4̄70954 & $1-$ \\
\hline Metulocladosporiella musae & CBS 161.74 & DQ008161 & DQ008137 \\
\hline Microsporum audouinii & CBS 332.68 & MH870861 & MH859149 \\
\hline Microxiphium purpuraefaciens & CBS 201.30 & MH866560 & MH855112 \\
\hline Microxiphium theae & CBS 202.30 & MH866561 & MH855113 \\
\hline Minimelanolocus rousselianus & CBS 126086 & / & MH863784 \\
\hline Minutiella tardicola & CBS 121757 & NG_057826 & NR_132006 \\
\hline Mollisia cinerea & AFTOL-ID 76 & DQ4770942 & DQ491498 \\
\hline Monascus ruber & CBS 135.60 & МH869468 & MH857924 \\
\hline Moristroma japonicum & BN1674 & AY254052 & AY254052 \\
\hline Moristroma quercinum & BN1678 & AY254051 & AY254051 \\
\hline Muellerella erratica & Ertz 20485 & MN241079 & / \\
\hline Mycocalicium americanum & Kalb \& Nash & / & AY795879 \\
\hline Mycocalicium hyaloparvicellulum & MFLUCC 14-0169 & KR920005 & KR920004 \\
\hline Mycosphaerella graminicola & AFTOL-ID 1615 & DQ678084 & / \\
\hline Myriodontium keratinophilum & CBS 947.73 & NG_063938 & NR_157454 \\
\hline Nadsoniella nigra & CBS 535.94 & NG_059253 & NR_154974 \\
\hline Nannizzia incurvata & CBS 174.64 & NG_057715 & NR_155473 \\
\hline Nannizziopsis chlamydospora & strain 1824 & KR0̄63660 & KRㅡㄴㄱ4ㄴ \\
\hline Nannizziopsis crocodili & UAMH 9666 & / & KF477204 \\
\hline Nannizziopsis pluriseptata & UTHSC 10-1045 & NG_042532 & NR_111524 \\
\hline Neocatapyrenium rhizinosum & AFTOL-ID 2282 & EF643757 & $1-$ \\
\hline Neocladophialophora quercina & CBS 138874 & MH877670 & KP004470 \\
\hline Neogymnomyces virgineus & DCDSL7716 & JN038186 & JN038187 \\
\hline Neophaeococcomyces aloes & СРC 21873 & KF777234 & KF777182 \\
\hline Neophaeomoniella eucalypti & CBS 139919 & NG_058174 & NR_138001 \\
\hline Neostrelitziana acaciigena & CBS:139903 & NG_058165 & NR_137987 \\
\hline Normandina pulchella & TNS:Ohmura 7853 & KF972457 & $1-1$ \\
\hline Norrlinia peltigericola & Palice 4369 & AY300845 & l \\
\hline Nullicamyces eucalypti & CPC 32942 & MH327843 & МH327807 \\
\hline Onychocola glareosa & UAMH 10000 & l & AY624315 \\
\hline Onygena equina & ATCC 22731 & AY176717 & / \\
\hline Ophidiomyces ophiodiicola & UAMH 11295 & / & KF477237 \\
\hline Ophiocordyceps gracilis & OSC 151906 & KJ878890 & / \\
\hline Ophiocordyceps sinensis & YN09-64 & JX968033 & JQ325141 \\
\hline Ophiocordyceps variabilis & OSC 111003 & EF468839 & 1 \\
\hline Ophiodiaporthe cyatheae & YMJ 1364 & JX570891 & JX570889 \\
\hline Orbilia vinosa & AFTOL-ID 905 & DQ470952 & DQ491511 \\
\hline Ovadendron sulphureoochraceum & CBS 125.81 & KT155095 & KT155767 \\
\hline Paecilomyces divaricatus & CBS 284.48 & MH867896 & MH856344 \\
\hline Parabagliettoa dufourii & CG579 & l & KM371425 \\
\hline Paracladophialophora carceris & СРC 27596 & l & NR_154360 \\
\hline Paracladophialophora cyperacearum & CPC 33046 & MH327844 & NR_160625 \\
\hline Paracoccidioides brasiliensis & CBS 372.73 & MH872413 & MH860706 \\
\hline Paranannizziopsis australasiensis & UAMH 11645 & l & KF477220 \\
\hline Paraphaeomoniella capensis & CPC 15416 & NG_057814 & NR_137711 \\
\hline Paraphyton cookei & CBS 228.58 & NG_058188 & NR_155665 \\
\hline Pectinotrichum llanense & CBS 882.71 & NG_057620 & NR_119467 \\
\hline Peltula auriculata & AFTOL-ID 892 & DQ8332330 & DQ832329 \\
\hline Peltula umbilicata & AFTOL-ID 891 & DQ832334 & DQ832333 \\
\hline Penicilliopsis clavariiformis & CBS 257.33 & MH866881 & MH855432 \\
\hline Penicillium euglaucum & CBS 323.71 & NG_067394 & NR_121517 \\
\hline Penicillium hennebertii & CBS 334.68 & NG_057625 & NR_160113 \\
\hline Peziza vesiculosa & AFTOL-ID 507 & DQ4770948 & DQ491509 \\
\hline Phacidium lacerum & AFTOL-ID 1253 & DQ470976 & l \\
\hline Phaeoannellomyces elegans & CBS 122.95 & KY115194 & NR_155687 \\
\hline Phaeocalicium curtisii & BIOUG24047-F02 & 1 & KTб̄95401 \\
\hline
\end{tabular}


Table 1 Continued.

\begin{tabular}{|c|c|c|c|}
\hline \multirow{2}{*}{ Species } & \multirow{2}{*}{ Voucher/Strain } & \multicolumn{2}{|c|}{ GenBank accession numbers } \\
\hline & & LSU & ITS \\
\hline Phaeocalicium populneum & Tibell 19286 & AY796009 & AY795874 \\
\hline Phaeococcomyces nigricans & CBS 652.72 & AF361048 & AF050278 \\
\hline Phaeosaccardinula ficus & MFLUCC 10-0009 & HQ895837 & HQ895840 \\
\hline Phialomyces macrosporus & CBS 430.64 & MH870110 & MH858478 \\
\hline Phialophora verrucosa & CBS 140325 & l & NR_146242 \\
\hline Phyllobaeis imbricate & AFTOL-ID 852 & DQ986781 & HQ650635 \\
\hline Piedraia hortae & CBS 480.64 & GU214466 & GU214647 \\
\hline Placidiopsis custnani & MA16310 & GQ344578 & GQ344604 \\
\hline Placidium michelii & M. Prieto 1356 & GU228909 & 1 \\
\hline Placocarpus schaereri & C. Gueidan 588 & 1 & EU006532 \\
\hline Plagiostoma euphorbiae & CBS 340.78 & AF408382 & DQ323532 \\
\hline Pleostigma jungermannicola & M174 & EU940119 & 1 \\
\hline Plicaria leiocarpa & AFTOL-ID 1345 & DQ842029 & l \\
\hline Polyblastia cupularis & AFTOL-ID 2239 & EF643769 & / \\
\hline Polytolypa hystricis & UAMH 7299 & NG_042396 & NR_111161 \\
\hline Potebniamyces pyri & AFTOL-ID 744 & DQ4770949 & DQ491510 \\
\hline Pseudoamauroascus australiensis & FMR 5482 & 1 & AJ131787 \\
\hline Pseudobactrodesmium aquaticum & MFLUCC 18-1015 & MN335230 & MN335228 \\
\hline Pseudophaeomoniella oleae & CBS 139191 & NG_060141 & NR_137966 \\
\hline Pseudospiromastix tentaculata & CBS 184.92 & NG_042397 & NR_111162 \\
\hline Pseudotulostoma volvatum & AMV1956 & $1-$ & КТ7̄24084 \\
\hline Pyrenula nitida & F 5929 & DQ329023 & JQ927458 \\
\hline Pyronema domesticum & AFTOL-ID 949 & DQ247805 & DQ491517 \\
\hline Pyxidiophora arvernensis & AFTOL-ID 2197 & FJ176894 & I \\
\hline Pyxine subcinerea & AFTOL-ID 686 & DQ883802 & HQ650705 \\
\hline Racodium rupestre & L346 & EU048583 & GU067666 \\
\hline Rasamsonia emersonii & CBS 266.71 & MH871885 & MH860109 \\
\hline Renispora flavissima & CBS 708.79 & KC989737 & AF299348 \\
\hline Rhinocladiella atrovirens & CBS 264.49 & EU041869 & MH856518 \\
\hline Rhizina undulata & AFTOL-ID 918 & DQ470961 & l \\
\hline Rhopalophora clavispora & CBS 637.73 & NG_058262 & KX537753 \\
\hline Rhynchostoma proteae & CBS 112051 & EU5̄52154 & NR_132824 \\
\hline Roccella fuciformis & AFTOL-ID 126 & AY584654 & DQ7̄82840 \\
\hline Rocellographa cretacea & AFTOL-ID 93 & DQ883696 & / \\
\hline Rutstroemia firma & AFTOL-ID 923 & DQ470963 & l \\
\hline Sagenomella diversispora & CBS 354.36 & MH867323 & MH855819 \\
\hline Sarcinomyces crustaceus & CBS 156.89 & GU250893 & $\mathrm{AJ} 244258$ \\
\hline Sarcoscypha coccinea & AFTOL-ID 50 & AY544647 & DQ491486 \\
\hline Sarcosoma latahense & AFTOL-ID 954 & FJ176860 & 1 \\
\hline Schaereria fuscocinerea & T1291 & KR017225 & KR017085 \\
\hline Schismatomma decolorans & Ertz 5003 & AY548815 & AY548808 \\
\hline Sclerocleista ornata & NRRL4735 & AF433095 & EF669703 \\
\hline Sclerococcum sphaerale & Ertz 17425 & JX081674 & l \\
\hline Sclerophora farinacea & Wedin 6414 & JX000095 & JX000113 \\
\hline Sclerotinia sclerotiorum & AFTOL-ID 928 & DQ470965 & / \\
\hline Scutellinia scutellata & AFTOL-ID 62 & DQ247806 & DQ491492 \\
\hline Shanorella spirotricha & CBS 304.56 & FJ358288 & MH857651 \\
\hline Sigleria carmichaelii & CBS 138264 & KP119638 & KP119626 \\
\hline Sordaria fimicola & AFTOL-ID 216 & AY545728 & DQ518178 \\
\hline Sphaerosporium equinum & MUCL 46080 & JQ434642 & JQ434578 \\
\hline Sphaerosporium lignatile & D. Haelew. F-1614a & MN749494 & MN749372 \\
\hline Sphinctrina turbinata & Tibell 23093 & DQ009001 & AY795877 \\
\hline Sporendonema casei & CBS 543.75 & MH872720 & MH860952 \\
\hline Sporodictyon schaererianum & AMNH:LA31905 & KY773252 & KY697132 \\
\hline Staurothele clopima & $\mathrm{W} 1235$ & JN573792 & / \\
\hline Stenocybe pullatula & Tibell 17117 & AY796008 & AY795878 \\
\hline Strelitziana africana & ICMP_21760 & MK210501 & MK210540 \\
\hline Strelitziana australiensis & CBS $1 \overline{2} 4778$ & GQ303326 & GQ303295 \\
\hline
\end{tabular}


Table 1 Continued.

\begin{tabular}{|c|c|c|c|}
\hline \multirow{2}{*}{ Species } & \multirow{2}{*}{ Voucher/Strain } & \multicolumn{2}{|c|}{ GenBank accession numbers } \\
\hline & & LSU & ITS \\
\hline Talaromyces macrosporus & CBS 317.63 & MH869909 & MH858299 \\
\hline Testudomyces verrucosus & CBS 500.86 & / & AJ315841 \\
\hline Thelidium pertusatii & JN1541 & l & EU249472 \\
\hline Thermoascus aurantiacus & CBS 398.64 & MH870100 & MH858464 \\
\hline Thysanorea papuana & CBS 212.96 & MH874198 & MH862572 \\
\hline Trichocoma paradoxa & CBS 103.73 & MH872339 & MH860643 \\
\hline Trichoderma viride & DAOM JBT1003 & JN938865 & JN942883 \\
\hline Trichoglossum hirsutum & AFTOL-ID 64 & AY544653 & DQ491494 \\
\hline Trichomerium foliicola & MFLUCC 10-0078 & JX313661 & JX313655 \\
\hline Trichophyton tonsurans & CBS 496.48 & MH867992 & MH856446 \\
\hline Trimmatothele perquisita & T560 & EU598695 & EU559742 \\
\hline Tripospora tripos & PREM 61202 & 1 & NR_164231 \\
\hline Umbilicaria mammulata & AFTOL-ID 645 & DQ782912 & DQ7782851 \\
\hline Uncinocarpus reesii & CBS 121.77 & MH872807 & MH861035 \\
\hline Uncispora sinensis & YMF1.03683 & KU558914 & KU173860 \\
\hline Usnea antarctica & AFTOL-ID 813 & DQ883692 & HQ650616 \\
\hline Veronaea botryosa & CBS 254.57 & EU041873 & MH857711 \\
\hline Verrucaria rupestris & SS043 & EU598724 & EU553501 \\
\hline Verruculopsis poeltiana & AFTOL-ID 2298 & EF643822 & EU010257 \\
\hline Vibrissea truncorum & AFTOL-ID 1322 & FJ176874 & / \\
\hline Vonarxia vagans & CBS 123533 & FJ839672 & FJ839636 \\
\hline Wahlenbergiella mucosa & A. Orange 16305 & FJ664875 & FJ664875 \\
\hline Willeya diffractella & Harris 44093 & / & KM371613 \\
\hline Xanthothecium peruvianum & CBS 112.54 & NG_057623 & MH857258 \\
\hline Xenocylindrosporium kirstenboschense & CBS 125545 & NG_057857 & NR_132841 \\
\hline Xerochrysium dermatitidis & CBS 132.31 & NG_058454 & KY635853 \\
\hline Xeromyces bisporus & CBS 236.71 & NG_057813 & NR_154540 \\
\hline Xylaria hypoxylon & AFTOL-ID 51 & AY $\overline{5} 44648$ & DQ491487 \\
\hline Zodiomyces vorticellarius & MG003 & KT800022 & 1 \\
\hline
\end{tabular}

\section{Results}

Outline of Chaetothyriales, as of July 2021, updated data as compared with Wijayawardene et al. (2020) are marked with an asterisk $(*)$

Eurotiomycetes Tehler ex O.E. Eriksson \& K. Winka

Chaetothyriomycetidae Doweld

Chaetothyriales M.E. Barr

Chaetothyriaceae Hansf. ex M.E. Barr

Actinocymbe Höhn. (3)

Aithaloderma Syd. \& P. Syd. (13)

Aphanophora Réblová \& Unter. (1)

Barreto (1)*

Arthrophiala (D.J. Soares, R.W. Barreto \& U. Braun) W.S. Lisboa, Meir. Silva \& R.W.

Beelia F. Stevens \& R.W. Ryan (3)

Camptophora Réblová \& Unter. (2)

Ceramothyrium Bat. \& H. Maia (36)*

Ceratocarpia Rolland (2)

Chaetothyriomyces Pereira-Carv., Inácio \& Dianese (1)

Chaetothyrium Speg. (45)*

Cyphellophoriella Crous \& A.J. Sm. (1)

Longihyalospora D.S. Tennakoon, C.H Kuo \& K.D. Hyde (2)

Nullicamyces Crous (1)

Phaeosaccardinula P. Henn. (27) 
Stanhughesia Constant. (1)

Treubiomyces Höhn. (7)

Vonarxia Bat. (2)

Coccodiniaceae Höhn. ex O.E. Erikss.

Coccodinium A. Massal. (4)

Dennisiella Bat. \& Cif. (7) = Microxiphium (Harv. ex Berk. \& Desm.) Thüm. (14)*

Limacinula Höhn. (12) *

Cyphellophoraceae Réblová \& Unter.

Anthopsis Fil. March., A. Fontana \& Luppi Mosca (2)

Cyphellophora G.A. de Vries (26)*

Epibryaceae S. Stenroos \& Gueidan

Epibryon Döbbeler (46) *

Herpotrichiellaceae Munk

Aculeata W. Dong, H. Zhang \& K.D. Hyde (1)

Atrokylindriopsis Y.R. Ma \& X.G. Zhang (1)

Brycekendrickomyces Crous \& M.J. Wingf. (1)

Capronia Sacc. (79)*

Cladophialophora Borelli (38)*

Exophiala J.W. Carmich. (51)*

Fonsecaea Negroni (8)*

Marinophialophora J.F. Li, Phook. \& K.D. Hyde (1)

Melanoctona Qing Tian, Doilom \& K.D. Hyde (1)

Metulocladosporiella Crous, Schroers, J.Z. Groenew., U. Braun \& K. Schub. (6)

Minimelanolocus R.F. Castañeda \& Heredia (34)*

Phialophora Medlar (41)*

Pleomelogramma Speg. (2)

Rhinocladiella Nannf. (17)

Sorocybe Fr. (3)

Thysanorea Arzanlou, W. Gams \& Crous (14)*

Uncispora R.C. Sinclair \& Morgan-Jones (4)*

Veronaea Cif. \& Montemart. (19)*

Lyrommataceae Lücking

Lyromma Bat. (8)*

Microtheliopsidaceae O.E. Erikss.

Microtheliopsis Müll. Arg. (4)

Paracladophialophoraceae Crous

Paracladophialophora Crous (2)

Pyrenotrichaceae Zahlbr

Pyrenothrix Riddle (2)

Neophaeococcomyces Crous \& M.J. Wingf. (4)*

Trichomeriaceae Chomnunti \& K.D. Hyde (= Strelitzianaceae Crous \& M.J. Wingf.)

Arthrocladium Papendorf (4) 
Bradymyces Hubka, Réblová, Selbmann \& M. Kolařík (3)

Knufia L.J. Hutchison \& Unter. (139)*

Lithohypha Selbmann \& Isola (3)*

Neostrelitziana Crous \& M.J. Wingf. (1)

Strelitziana Arzanlou \& Crous (8)

Trichomerium Speg. (29)*

\section{Chaetothyriales genera incertae sedis}

Bacillicladium Hubka, Réblová \& Thureborn (2)*

Euceramia Bat. \& Cif. (1)*

Lichenodiplis Dyko \& D. Hawksw. (= Laeviomyces D. Hawksw.) (13)

Melanina Grube, Muggia \& de Hoog (1)*

\section{Genera excluded from Chaetothyriales}

Microcallis Syd. (10)*

Yatesula Syd. \& P. Syd. (2)*

\section{Phylogeny}

The phylogenetic tree in Fig. 1 was constructed to verify the relationships of Eurotiomycetes in Ascomycota. The combined ITS and LSU gene analysis comprised 320 taxa with Armillaria mellea AFTOL-ID 449 as the outgroup taxon. The best scoring RAxML tree with a likelihood value is shown in Fig. 1.

The best-fit models of evolution obtained for the different datasets were ITS $=$ TVM+I+G, LSU $=$ $\mathrm{GTR}+\mathrm{I}+\mathrm{G}$, combined sequences $=\mathrm{TIM} 2+\mathrm{I}+\mathrm{G}$. No topological conflicts between the datasets were detected. Three hundred and twenty taxa were included in the combined ITS and LSU sequence analyses which comprised 1,916 characters including gaps (ITS $=1-574, \mathrm{LSU}=575-1916$ ). The best scoring RAxML tree with a final likelihood value of -106670.289774 was presented. The matrix had 1693 distinct alignment patterns, with $31.37 \%$ of undetermined characters or gaps. Estimated base frequencies were as follows, $\mathrm{A}=0.247262, \mathrm{C}=0.233934, \mathrm{G}=0.291391, \mathrm{~T}=0.227413$, substitution rates $\mathrm{AC}=1.293417, \mathrm{AG}=2.574842, \mathrm{AT}=1.517180, \mathrm{CG}=0.928081, \mathrm{CT}=5.845223, \mathrm{GT}=$ 1.000000 , gamma distribution shape parameter $\alpha=0.491701$.

The phylogenetic tree was obtained from both RAxML and Bayesian analyses, the Chaetothryirales clade comprises Trichomeriaceae, Coccodiniaceae, Chaetothyriaceae, Herpotrichiellaceae, Cyphellophoraceae, Paracladophialophoraceae and Epibryaceae. The Chaethothriaceae clade was relatively heterogeneous with 82\% ML BS, 0.93 BY PP support. The Herpotrichiellaceae clade was clearly distinct from Chaetothyriaceae, Trichomeriaceae and Coccodiniaceae. The Herpotrichiellaceae clade had 96\% ML BS, 1.00 BY PP support in both analyses. Species of this family are polyphyletic and divided into two groups. The other families, i.e. Coccodiniaceae was distinct (96\% ML BS and 1.00 BY PP) with one taxon; Coccodinium brtschii CPC13861. Cyphellophoraceae was a single, 82\% ML BS, 0.93 BY PP supported clade with Paracladophialophoraceae as a sister group.

Cyphellophoraceae comprises Cyphellophora guyanensis Decock \& G. Delgado (CBS 129342), Cy. laciniata G.A. de Vries (CBS 190.61), Anthopsis deltoidei Fil. March. et al. (CBS 263.77) and Chaetothyriales sp. (CBS 128959). Cyphellophora G.A. de Vries resembles Phialophora Medlar, but differs in conidial shape, while the type species Phialophora verrucosa, is a member of the "carrioniiclade' in Herpotrichiellaceae (de Hoog et al. 2011). In the present study, Strelitzianaceae is excluded from Chaetothyriales, and synonymized in Trichomeriaceae.

Epibryaceae comprised two strains, Epibryon plagiochilae (Gonz. Frag.) Döbbeler (ex-type strain, M187) and E. bryophilum (Fuckel) Döbbeler (M2), clustering with 100\% ML BS, 0.90 BY PP support. Fourty-seven species are accepted in Index Fungorum (2021), but only seven have sequence data in GenBank. 


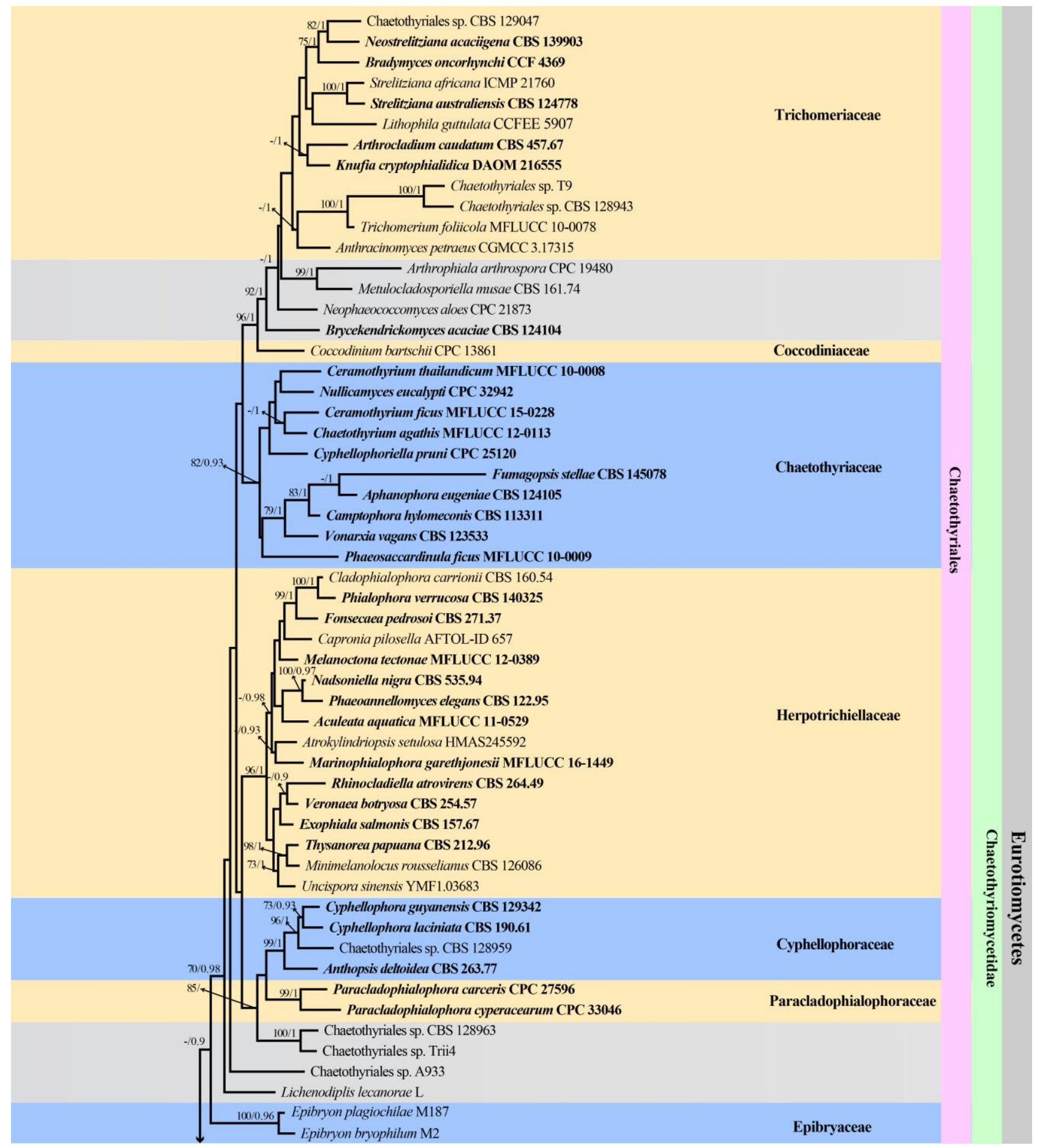

Figure 1 - Phylogenetic tree generated from maximum likelihood analysis based on combined ITS and LSU sequence data for species of Eurotiomycetes. Sequences were obtained from GenBank. Single gene analyses are carried out and compared with each species, the topology of the tree and clade stability. Armillaria mellea AFTOL-ID 449 is used as the outgroup taxon. The tree topology of the maximumlikelihood analysis is similar to the maximum parsimony analysis and the Bayesian analysis. Bootstrap support values for maximum likelihood (ML, first set) equal to or greater than $70 \%$ are given above or below the nodes. Branches with Bayesian posterior probabilities (BPP, second set) equal to or higher than 0.90 are given above or below the nodes. The hyphen ("-") indicates a value lower than $70 \%$ for ML BS or 0.90 for BY PP. Ex-type and ex-epitype strains are in bold. 


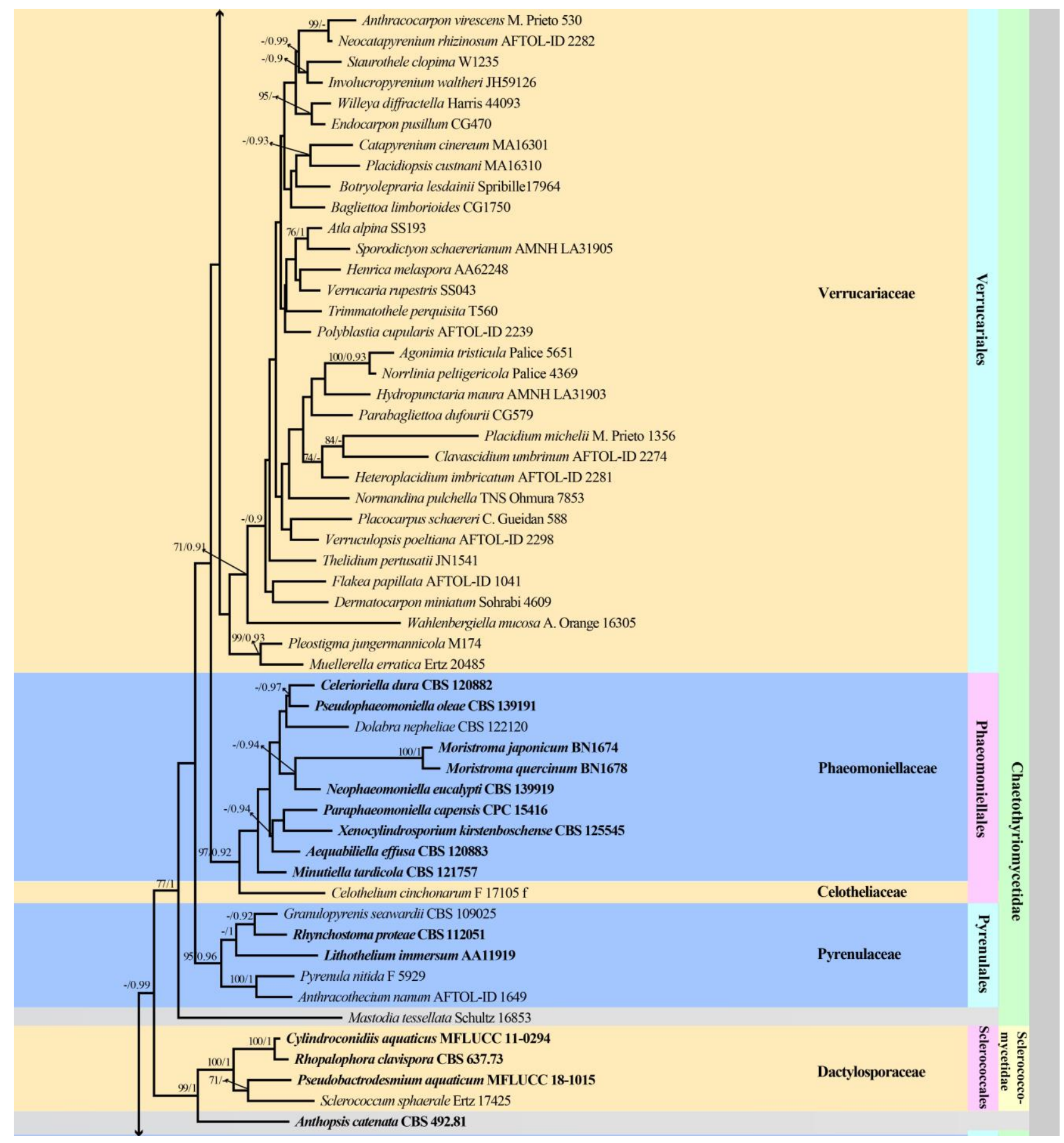

Figure 1 - Continued. 


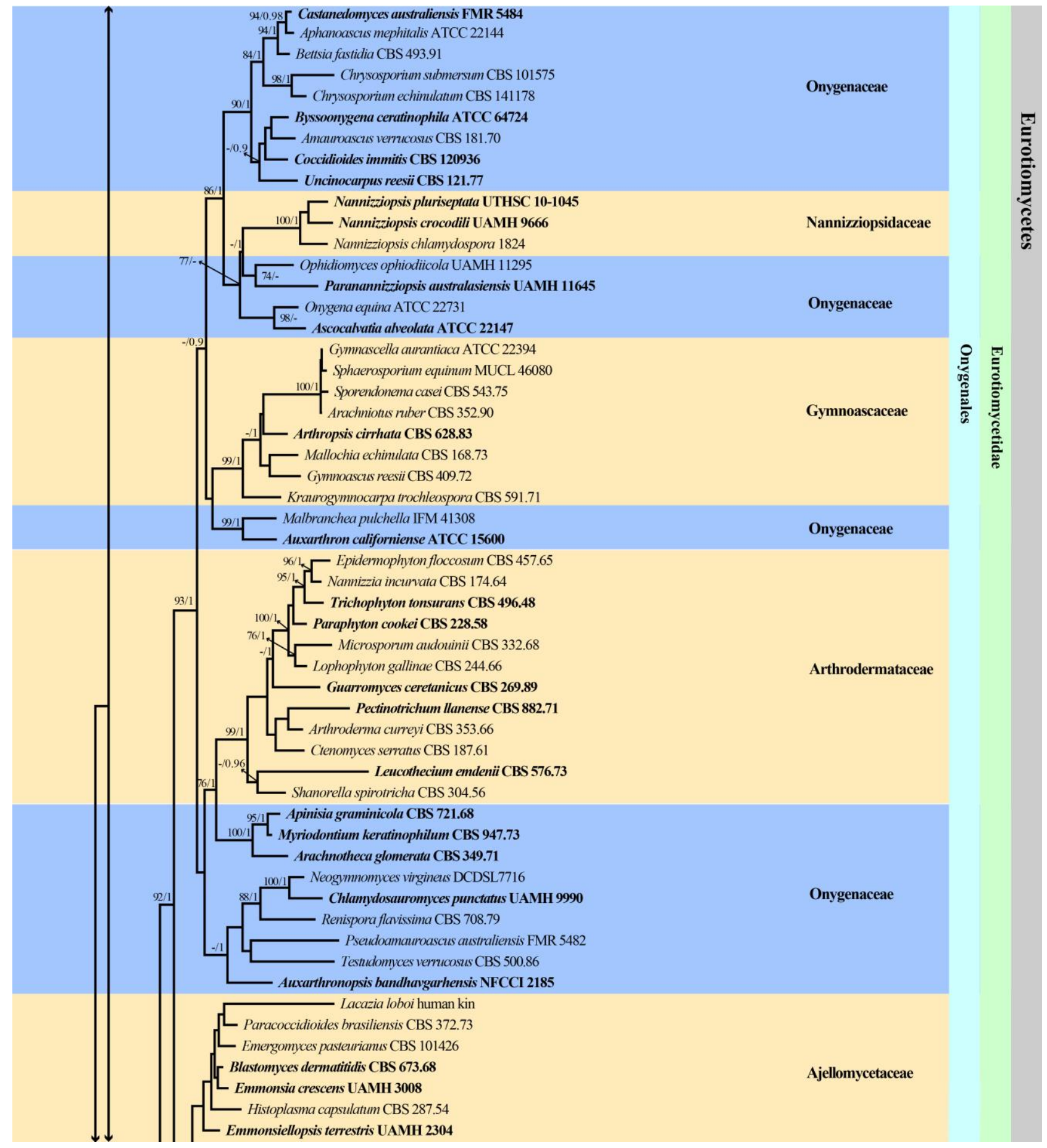

Figure 1 - Continued. 


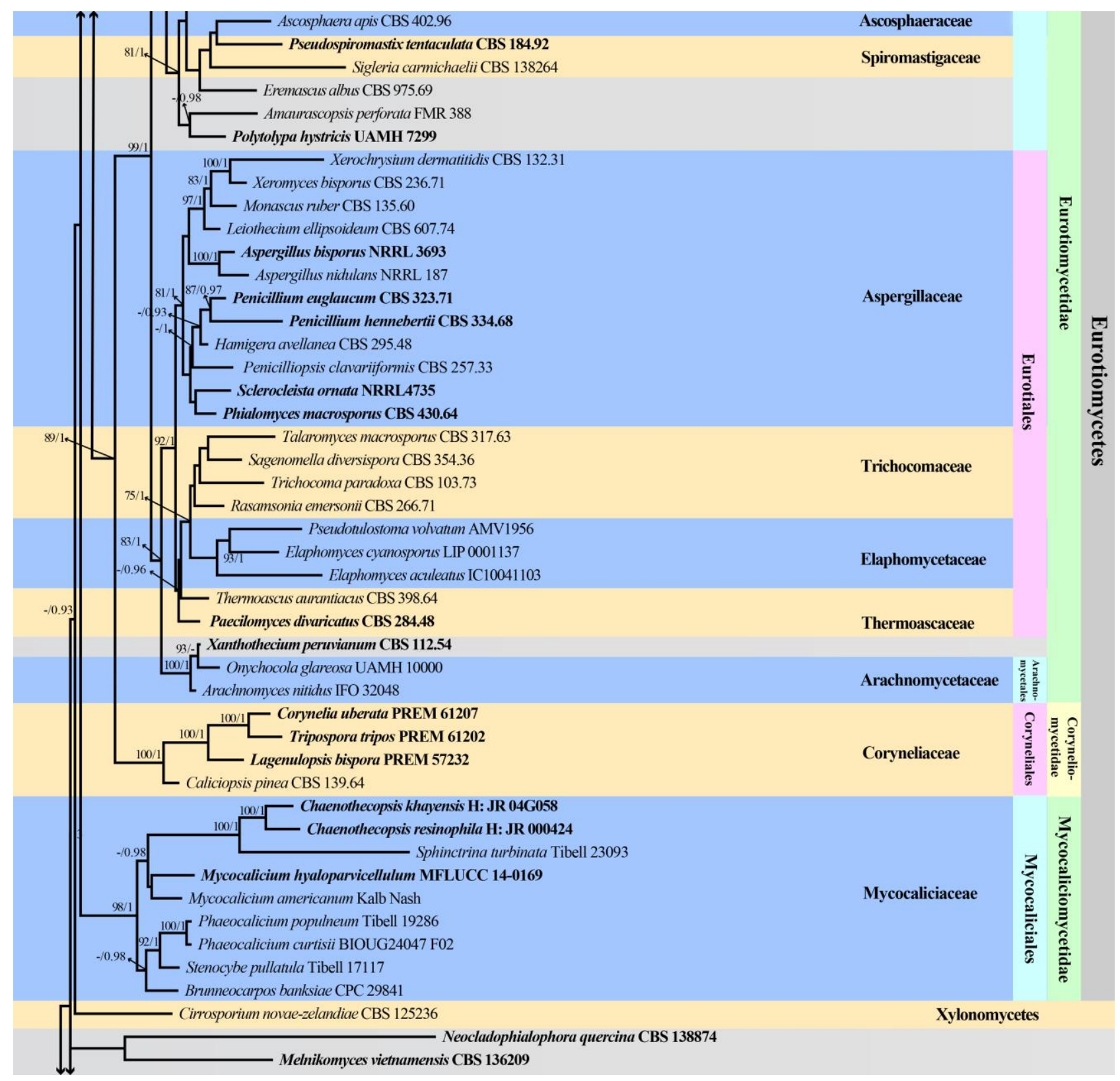

Figure 1 - Continued. 


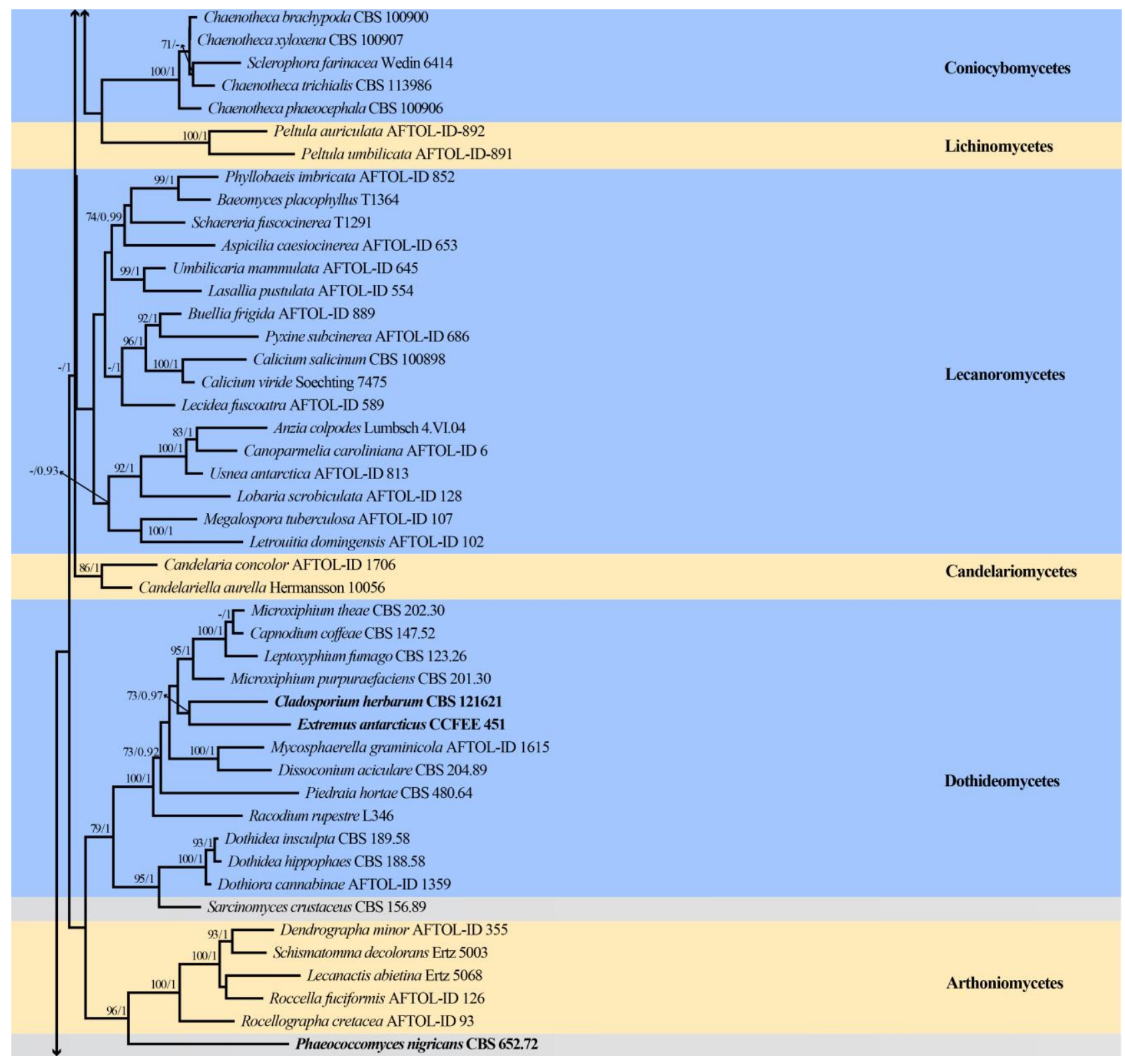

Figure 1 - Continued. 


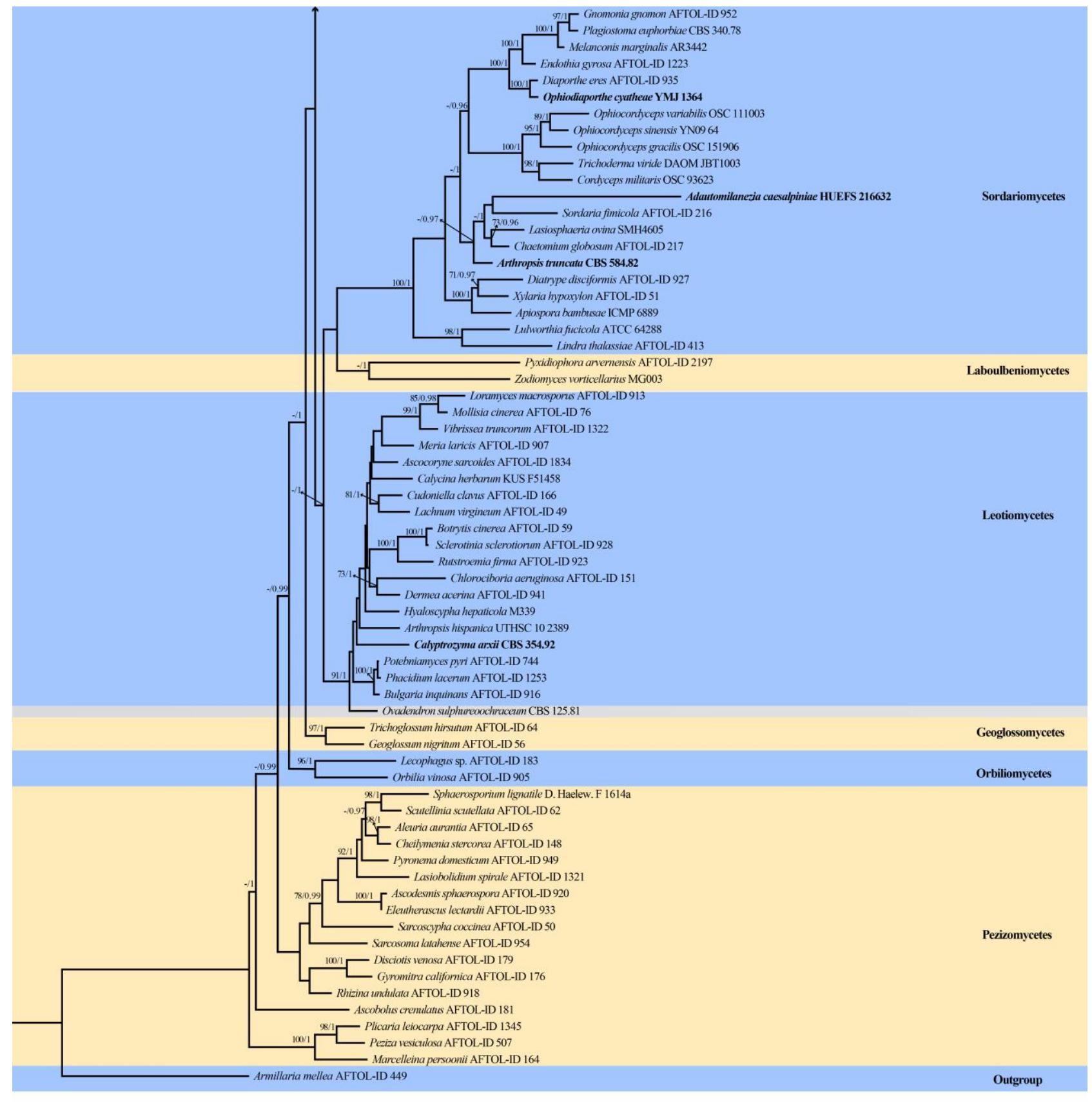

0.2

Figure 1 - Continued.

\section{Descriptions and notes on families and genera}

\section{Chaetothyriomycetidae Doweld}

Chaetothyriales M.E. Barr

Chaetothyriaceae Hansf. ex M.E. Barr, Mycologia 71(5): 943 (1979)

Index Fungorum number: IF80584; Facesoffungi number: FoF 10323

Epiphytic or saprobic on leaves and stems of various plants in terrestrial habitats. Sexual morph: Ascomata superficial, immersed to erumpent through cracking or splitting of the host tissue, solitary to gregarious, with periphysate ostioles, with or without papilla. Wall of ascoma composed of several layers, outer layers of dark brown cells, inner layers of hyaline to light brown flattened cells. Hamathecium lacking or comprising filiform, hyaline, septate paraphyses. Asci 4-8-spored, bitunicate, fissitunicate, oblong, clavate to nearly cylindrical, oval, sessile or short pedicellate, with or without an ocular chamber, forming in a basal layer, often interspersed with and covered by cellular remnants of 
interthecial tissues. Ascospores overlapping 1-multi-seriate, irregularly arranged, ellipsoid to broadly obovoid, fusiform to cylindrical, hyaline or lightly pigmented, yellowish to brownish, aseptate or 1-2trans-septate, or muriform, thin-walled, with or without a gelatinous sheath or appendages, guttulate or eguttulate. Asexual morph: coelomycetous and hyphomycetous.

Type - Chaetothyrium Speg.

Notes - Chaetothyriaceae was established by Hansford (1946) with Chaetothyrium Speg. as the type genus (type species: C. guaraniticum Speg. fide Spegazzini 1888). The family is characterized by superficial ascomata produced beneath a mycelial pellicle, with or without setae and mainly bitunicate asci (Batista et al. 1960, Batista \& Ciferri 1962, von Arx \& Müller 1975, Hughes 1976, PereiraCarvalho et al. 2009, Chomnunti et al. 2012, 2014, Tian et al. 2014, Zeng et al. 2016, Yang et al. 2018). Species of Chaetothyriaceae are mostly epiphytes, and resemble other sooty mould families, such as Capnodiaceae Höhn. ex Theiss. because of their similar morphology and habitat preferences. Species in both families are associated with insects and isolated from the same hosts (Hansford 1946, Batista \& Ciferri 1962, Chomnunti et al. 2012a, b, 2014). Most of the previous work included only brief descriptions and indistinct illustrations or simple line drawings, which not been a reliable guide to current research (Hansford 1946, Batista \& Ciferri 1962, von Arx \& Müller 1975, Hughes 1976). The placement of this family in Eurotiomycetes was clarified with high support in phylogenetic analysis (Winka et al. 1998, Chomnunti et al. 2012a, b, 2014). However, the family is still poorly circumscribed because: (1) the brief descriptions and some illustrations are not a reliable guide to current research; (2) previous studies for the arrangement of genera based on subjective morphology are hard to follow (For example, with or without setae, spore septation fide Batista \& Ciferri 1962, Hughes 1976); (3) lacking DNA sequence data. Wijayawardene et al. (2020) accepted 20 genera in Chaetothyriaceae, but only ten genera have molecular data in GenBank. Therefore, it is essential to re-examine the type species of each genus of Chaetothyriaceae and provide detailed morphological information and focus on collecting more taxa of Chaetothyriaceae to obtain molecular data towards resolving a natural classification.

Chaetothyrium Speg., Anal. Soc. cient. argent. 26(1): 46 (1888)

Index Fungorum number: IF978; Facesoffungi number: FoF 10324, 45 morphological species (Species Fungorum 2021), 2 species with molecular data.

Saprobic on leaves. Sexual morph: Ascomata appearing as black dots scattered on the upper surface, developing beneath a brown layer attached to the leaf surface, scattered, subglobose to circular, cupulate on drying, brown to dark brown, ostiole or papilla not apparent. Setae scattered, dark brown to black at the apex, erect. Wall of ascoma thicker at the apex, multi-layered, pseudoparenchymatous, comprising pigmented, thick-walled cells of textura angularis, with inner layer thinner, flattened, lightly pigmented to hyaline, thin-walled cells. Hamathecium lacking paraphyses. Asci 8-spored, bitunicate, clavate to ellipsoid, shortly pedicellate or sessile. Ascospores overlapping uni-seriate or biseriate, oblong-ellipsoid, obovoid, hyaline, septate or muriform, slightly constricted at the septa, smooth and thick-walled, lacking a gelatinous sheath or appendages. Asexual morph: Undetermined.

Type species - Chaetothyrium guaraniticum Speg. [as 'guaranticum']

Notes - Chaetothyrium is the type genus of Chaetothyriaceae. Species in Chaetothyrium are referred to as sooty moulds because of the similarity of appearance and ecology to capnodiaceous sooty moulds. The black mycelia reduce photosynthesis rates in the host. Some species in Chaetothyrium, such as $C$. vermisporum Hansf., are fly-speck taxa (forming thyriothecia on darkly pigmented blemishes and smudges on stems or leaves of living or dead hosts) which can be identified by their pellicle structures that press the thyriothecia close to the leaf (Hofmann \& Piepenbring 2006). However, other species in Chaetothyrium have perithecia on the surface of host organs (Hofmann \& Piepenbring 2006). Merismella Syd. (M. concinna Sydow, type species) has been reported as the asexual morph of Chaetothyrium (C. vermisporum) due to its similar fruiting body characters when they examined the same host specimen, while $C$. vermisporum has setae with a ring around the thyriothecia (Hofmann \& Piepenbring 2006). The sexual / asexual connection was accepted by Hyde et al. (2011), Chomnunti et al. (2012a) and Wijayawardene et al. (2012). However, Merismella has not yet been formally synonymized under Chaetothyrium. Presently, 45 species are referred to Chaetothyrium 
(Species Fungorum 2021). There is few sequence data for Chaetothyrium in GenBank (July, 2021). Winka et al. (1998) showed that Ceramothyrium linnaeae (Dearn.) S. Hughes is closely related to Chaetothyrium based on SSU rDNA sequence analysis. Chomnunti et al. (2012a) introduced a new species, $C$. bischofiicola Chomnunti et al., and included LSU and ITS rDNA sequence data for this genus and verified the position of Chaetothyrium in Chaetothyriaceae (Chaetothyriales, Eurotiomycetes). Liu et al. (2015) introduced C. agathidis Hongsanan \& K.D. Hyde and provided further sequence data for this genus. Nevertheless, further studies with more taxon sampling are needed for a better understanding of Chaetothyrium and to verify whether the genus is monophyletic (Badali et al. 2008, Gueidan et al. 2008, Untereiner et al. 2011, Chomnunti et al. 2012a). Quan et al. (2020) proposed C. agathidis (Liu et al. 2015) as the neotype of Chaetothyrium, however, Chaetothyrium agathidis resembles $C$. guaraniticum in having long setae but ascospores of $C$. agathidis are cylindrical with 3-7 septa, while in $C$. guaraniticum they are oblong-ellipsoid with 1-3-septa. Therefore, we herewith proposed to designate $C$. agathidis as a representative type of Chaetothyrium. Our combined LSU and ITS sequence data demonstrate a close relationship between $C$. agathidis and the sooty mould species Ceramothyrium ficus (66\% ML BS and 1.00 BY PP support, Fig. 1). We also provide an appropriate description and photo-plate of the type species $C$. guaraniticum Speg. from an Indian collection.

Chaetothyrium guaraniticum Speg. [as 'guaranticum'], Anal. Soc. cient. argent. 26(1): 46 (1888)

Index Fungorum number: IF569945; Facesoffungi number: FoF 10325

Fig. 2

Saprobic on Aegle marmelos. Sexual morph: Ascomata $95-185 \mu \mathrm{m}$ high $\times 80-110 \mu \mathrm{m}$ diam. $(\overline{\mathrm{x}}=$ $111 \times 90 \mu \mathrm{m}, \mathrm{n}=10$ ), perithecial, solitary, scattered, superficial, subglobose to circular, brown to dark brown, lacking an ostiole or papilla, appearing as black dots scattered on the upper surface of leaves. Setae $45-100 \times 1.8-3.6 \mu \mathrm{m}(\overline{\mathrm{x}}=78 \times 2.4 \mu \mathrm{m}, \mathrm{n}=10)$, scattered, dark brown to black at the apex, erect, rounded at the base and wider than the apex. Wall of ascoma 18-32 $\mu \mathrm{m}(\overline{\mathrm{x}}=25 \mu \mathrm{m}, \mathrm{n}=10)$, thicker at the apex, multi-layered, externally comprising pigmented, dark brown, thick-walled cells of textura angularis, with inner layer thinner, composed of irregularly-shaped, flattened, lightly pigmented to hyaline, thin-walled cells of textura angularis. Hamathecium lacking paraphyses. Asci 48-52 $\times 13-17$ $\mu \mathrm{m}(\overline{\mathrm{x}}=48 \times 15.8 \mu \mathrm{m}, \mathrm{n}=10), 8$-spored, bitunicate, fissitunicate, clavate to ellipsoid, short pedicellate or sessile, with an ocular chamber. Ascospores 18-27 $\times 3-5 \mu \mathrm{m}(\overline{\mathrm{x}}=24 \times 4.2 \mu \mathrm{m}, \mathrm{n}=10)$, overlapping uni-seriate or bi-seriate, oblong-ellipsoid, hyaline, 1-3 septate, constricted at the septa, smooth and thick-walled, lacking a gelatinous sheath or appendages. Asexual morph: Undetermined.

Material examined - India, Uttar Pradesh, on leaves of Aegle marmelos (L.) Corrêa (Rutaceae), 16 February 1962, Dwivedi R.S. (IMI 91630).

\section{Ecological and economic significance of Chaetothyriaceae}

Chaetothyriaceae species are known as epiphytes with the appearance of sooty moulds and mostly grow on the surface of living leaves apparently gaining nutrients from sugary exudates. They are characterized by dark mycelium adpressed to the surface of leaves and stems, but do not penetrate the host tissues (Batista \& Ciferri 1962, Chomnunti et al. 2012a, 2014). Sooty moulds are treated as a plant disease, growing on the surface of the plant tissues, as they can block sunlight from leaf chloroplasts and cause lower growth rates of plants and reduce yield (Nelson 2008, Laemmlen 2011). Chaetothyrium vermisporum looks like a fly-speck fungus which is identified by the pellicle structures that can press the perithecia close to the leaf (Hofmann \& Piepenbring 2006).

\section{Genera included in Chaetothyriaceae}

Actinocymbe Höhn., Sber. Akad. Wiss. Wien, Math.-naturw. Kl., Abt. 1 120: 416 (1911)

Index Fungorum number: IF60, Facesoffungi number: FoF 10326, 3 morphological species (Species Fungorum 2021), molecular data unavailable.

Type species - Actinocymbe separato-setosa (Henn.) Höhn. 


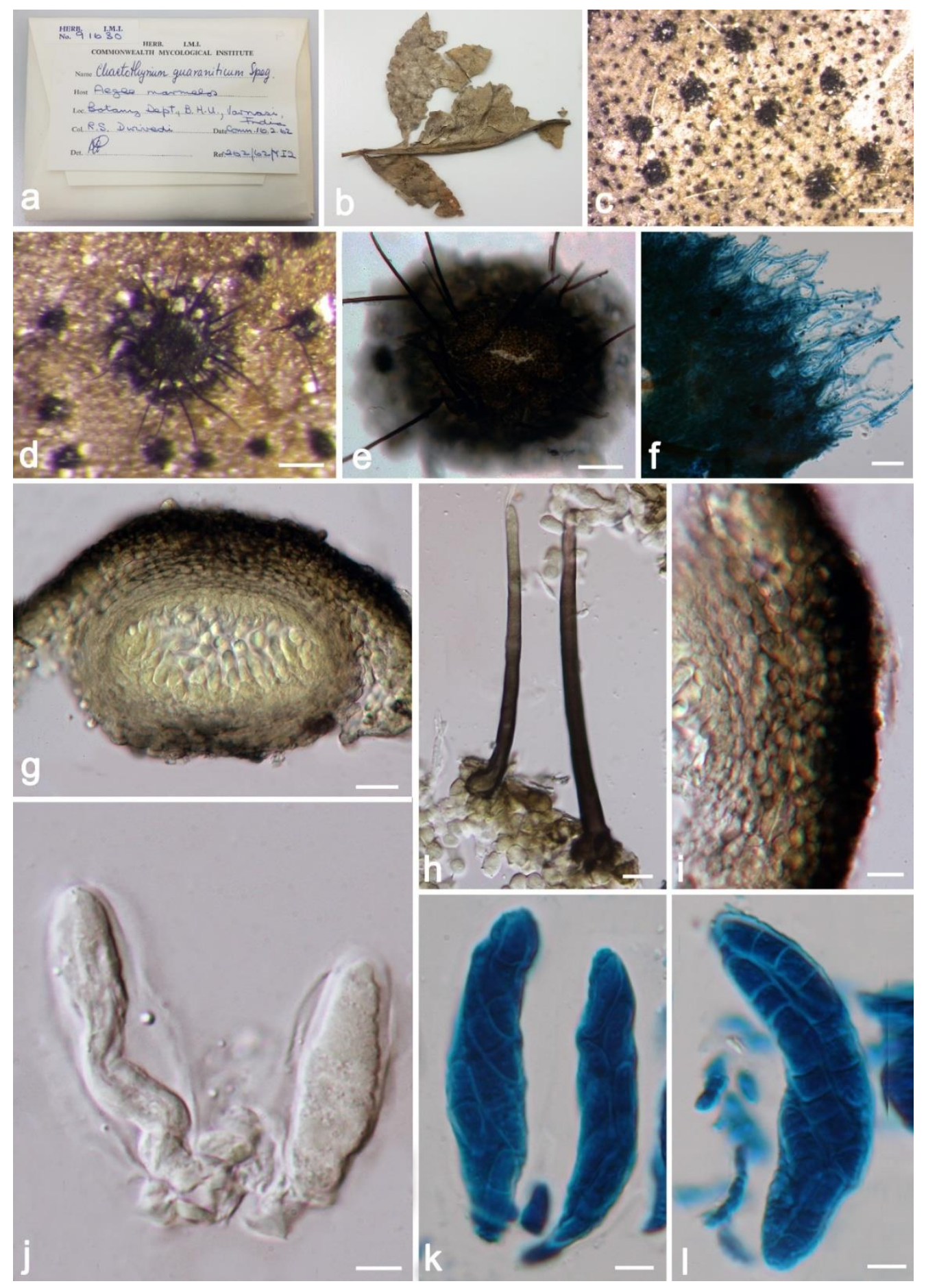

Figure 2 - Chaetothyrium guaraniticum (IMI 91630), a Envelop and collection information of Chaetothyrium guaraniticum. b Herbarium material. c Appearance of ascomata on the leaves of Aegle marmelos. d Globose ascoma with black setae. e Squash mount of ascoma. f Mycelial network attaching ascoma to the leaf surface. g Vertical sections of ascoma. h Ascomatal setae. i Vertical sections through ascoma wall. $\mathrm{j}$ Immature asci. $\mathrm{k}, 1$ Asci with ascospores, stained in lactophenol cotton blue. Scale bars: $\mathrm{c}=500 \mu \mathrm{m}, \mathrm{d}=100 \mu \mathrm{m}, \mathrm{e}, \mathrm{g}=50 \mu \mathrm{m}, \mathrm{f}=20 \mu \mathrm{m}, \mathrm{i}=10 \mu \mathrm{m}, \mathrm{h}, \mathrm{j}-\mathrm{l}=5 \mu \mathrm{m}$.

Epiphytic on the surface of leaves. Sexual morph: Mycelium branched, septate, greyish brown, appressed to the cuticle. Ascomata perithecial, solitary, scattered, superficial to erumpent, subglobose to circular, brown to dark brown, ostiolate. Ostiole open, periphysate. Setae scattered to clustered, dark brown to black, erect, rounded at the base and wider than the apex. Wall of ascoma multi-layered, externally comprising pigmented, dark brown, thick-walled cells of textura angularis, with inner layer 
thinner, composed of irregularly-shaped, lightly pigmented to hyaline, thin-walled cells. Hamathecium paraphysate. Asci 8-spored, bitunicate, fissitunicate, clavate, long pedicellate, straight to slightly curved. Ascospores overlapping multi-seriate, oblong-ellipsoid, tapering at the ends, hyaline, usually 9-septate, without constriction at the septa, smooth and thick-walled, lacking a gelatinous sheath or appendages. Asexual morph: Undetermined.

Notes - Actinocymbe separato-setosa (Henn.) Höhn, A. congensis (Henn.) Hansf. and A. indica R.K. Verma \& Kamal were added to this genus which is characterized by setose ascomata, periphysate ostioles and oblong-ellipsoid ascospores (Höhnel 1911, von Arx \& Müller 1975, Verma \& Kamal 1987). Periphyses have been illustrated as an important character to identify species in Chaetothyriaceae (von Arx \& Müller 1975). There is no culture or molecular data available in GenBank (July, 2021). We re-examined the holotype of $A$. separato-setosa to provide an updated morphology. Based on the setiferous ascomata, periphysate ostioles and oblong-ellipsoid, multi-septate ascospores, we maintain Actinocymbe in Chaetothyriaceae.

Actinocymbe separato-setosa (Henn.) Höhn., Sber. Akad. Wiss. Wien, Math. -naturw. Kl., Abt. 1 120: $416(1911)$

Fig. 3

= Actiniopsis separato-setosa Henn., Hedwigia 47: 269 (1908)

Index Fungorum number: IF811417; Facesoffungi number: FoF 10327

Epiphytic on the surface of leaves, epiphyllous or sometimes hypophyllous. Mycelium 4-6 $\mu \mathrm{m}$ wide, branched, septate, greyish brown, appressed to the cuticle. Sexual morph: Ascomata 470-680 $\mu \mathrm{m}$ diam. $(\overline{\mathrm{x}}=590 \mu \mathrm{m}, \mathrm{n}=10)$, perithecial, solitary, scattered, superficial to erumpent, subglobose to circular, brown to dark brown, ostiolate. Ostiole open, periphysate. Setae 140-180 $\times 4-6 \mu \mathrm{m}(\overline{\mathrm{x}}=168 \times$ $5 \mu \mathrm{m}, \mathrm{n}=10$ ), scattered to clustered, dark brown to black, erect, rounded at the base and wider than the apex. Wall of ascoma $26-50 \mu \mathrm{m}(\overline{\mathrm{x}}=42 \mu \mathrm{m}, \mathrm{n}=10)$, multi-layered, externally comprising pigmented, dark brown, thick-walled cells of textura angularis, with inner layer thinner, composed of irregularlyshaped, flattened, lightly pigmented to hyaline, thin-walled cells of textura prismatica. Hamathecium

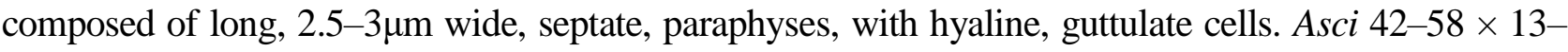
$19 \mu \mathrm{m}(\overline{\mathrm{x}}=46 \times 15 \mu \mathrm{m}, \mathrm{n}=10), 8$-spored, bitunicate, fissitunicate, clavate to ellipsoid, long pedicellate, straight to slightly curved. Ascospores $24-33 \times 4-7 \mu \mathrm{m}(\overline{\mathrm{x}}=28 \times 6 \mu \mathrm{m}, \mathrm{n}=10)$, overlapping multiseriate, oblong-ellipsoid, tapering at the ends, hyaline, usually 9-septate, without constrictions at the septa, smooth and thick-walled, lacking a gelatinous sheath or appendages. Asexual morph: Undetermined.

Material examined - Brazil, Amazonas, Rio Juruá, on leaves, May 1905, E. Ule (S-F12588, holotype).

Aphanophora Réblová \& Unter., PLoS ONE 8(5): e63547, 14 (2013)

Index Fungorum number: IF803677, Facesoffungi number: FoF 10328, 1 species with molecular data.

Type species - Aphanophora eugeniae (Crous \& Alfenas) Réblová \& Unter.

Epiphytic on the surface of living leaves. Sexual morph: Undetermined. Asexual morph: Mycelium composed of branched, septate, greenish-brown hyphae on PDA. Conidiophores lacking, reduced to conidiogenous cell. Conidiogenous cells phialidic, intercalary, hyaline, with the inconspicuous collarette, with aggregated loci. Conidia subcylindrical to cylindrical, hyaline to subhyaline, 4-6-septate, constricted at the septa, curved, smooth-walled, guttulate, each segment divided by a secondary median septum (Crous et al. 2009, Réblová et al. 2013).

Notes - Réblová et al. (2013) introduced Aphanophora Réblová \& Unter. to accommodate the type species Aphanophora eugeniae (Crous \& Alfenas) Réblová \& Unter. (Basionym: Cyphellophora eugeniae Crous \& Alfenas) with evidence from phylogenetic analysis and the morphological distinction between Aphanophora and Cyphellophora. Species of Aphanophora produce intercalary phialides and the cylindrical-elongate conidia are divided into septate segments. Aphanophora resembles Camptophora and they cluster together with high support (Réblová et al. 2013). However, the collarettes in Aphanophora are inconspicuous, and the multiple conidiogenous loci become swollen, 
while $C$. hylomeconis (Crous, de Hoog \& H.D. Shin) Réblová \& Unter. produces conspicuous phialides and has a single conidiogenous locus. In our phylogenetic analysis based on combined LSU and ITS sequence data, A. eugeniae clustered with Fumagopsis stellae Crous \& A.J. Carnegie and formed a sister group with $C$. hylomeconis (Fig. 1). However, F. stellae is distinctly based on its star-shaped conidia. Currently, no sexual morphs are linked to Aphanophora. Thus, the hyphomycetous genus Aphanophora is accepted in Chaetothyriaceae primarily based on phylogenetic analysis.

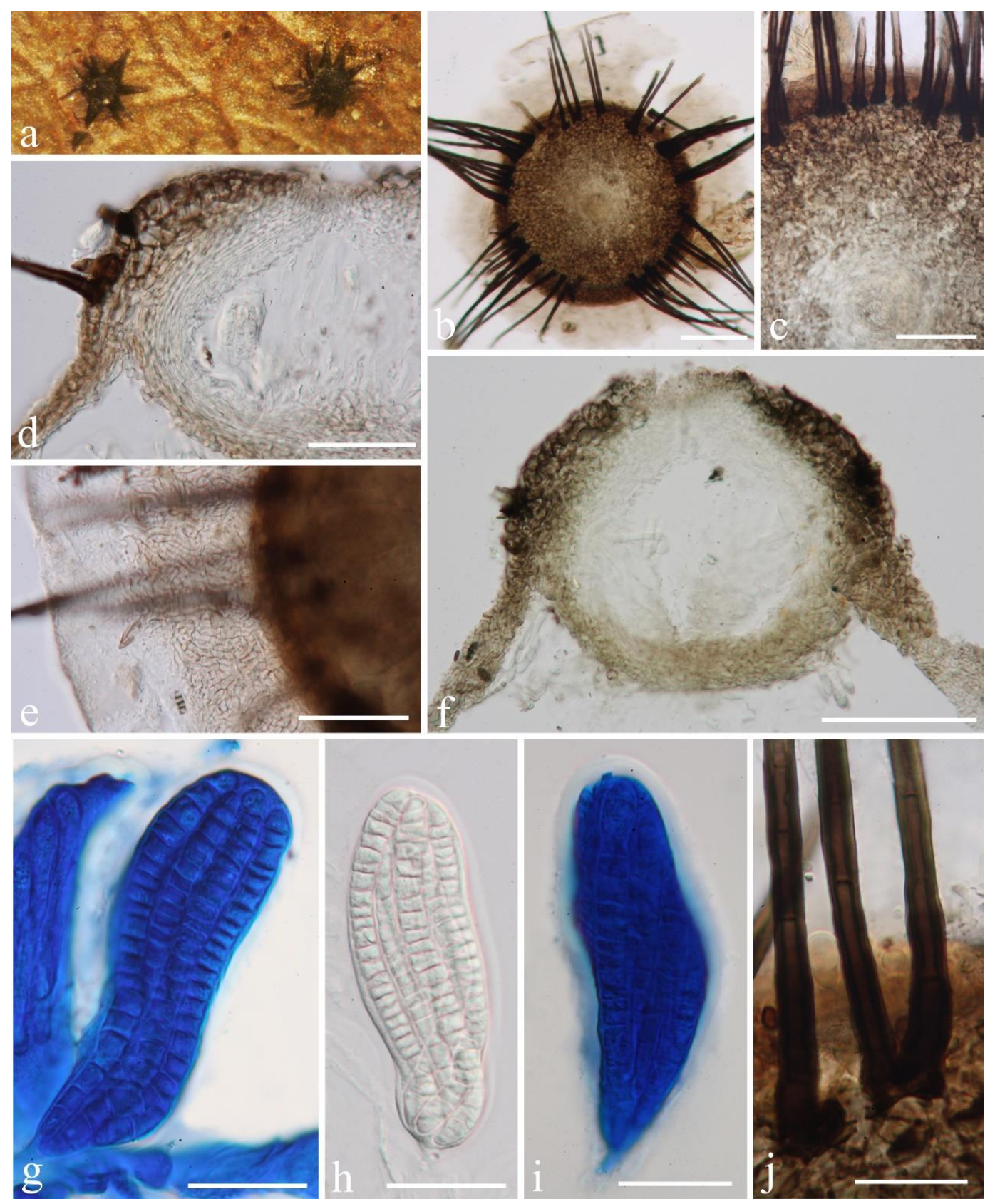

Figure 3 - Actinocymbe separato-setosa (S-F12588, holotype). a Appearance of superficial ascomata on the host. b, e Squash mount of ascoma. c Globose ascoma with black setae. d Vertical section through ascoma wall. f Vertical section of ascoma. g, i Asci with ascospores, stained in lactophenol cotton blue reagent. j Erect, septate, dark brown setae. Scale bars: $b, f=100 \mu \mathrm{m}, \mathrm{c}-\mathrm{e}=50 \mu \mathrm{m}, \mathrm{g}-\mathrm{j}=20$ $\mu \mathrm{m}$.

Aphanophora eugeniae (Crous \& Alfenas) Réblová \& Unter., PLoS ONE 8(5): e63547, 14 (2013) 
Index Fungorum number: IF803678; Facesoffungi number: FoF 10329

Description: see Réblová et al. (2013).

Type material - Brazil, Rio Grande do Sul, Guaiba, living leaves of Eugenia uniflora L. (Myrtaceae), 1 April 2008, leg. A.C. Alfenas, isol. P.W. Crous (CPC $15172=$ CBS 124105, ex-type).

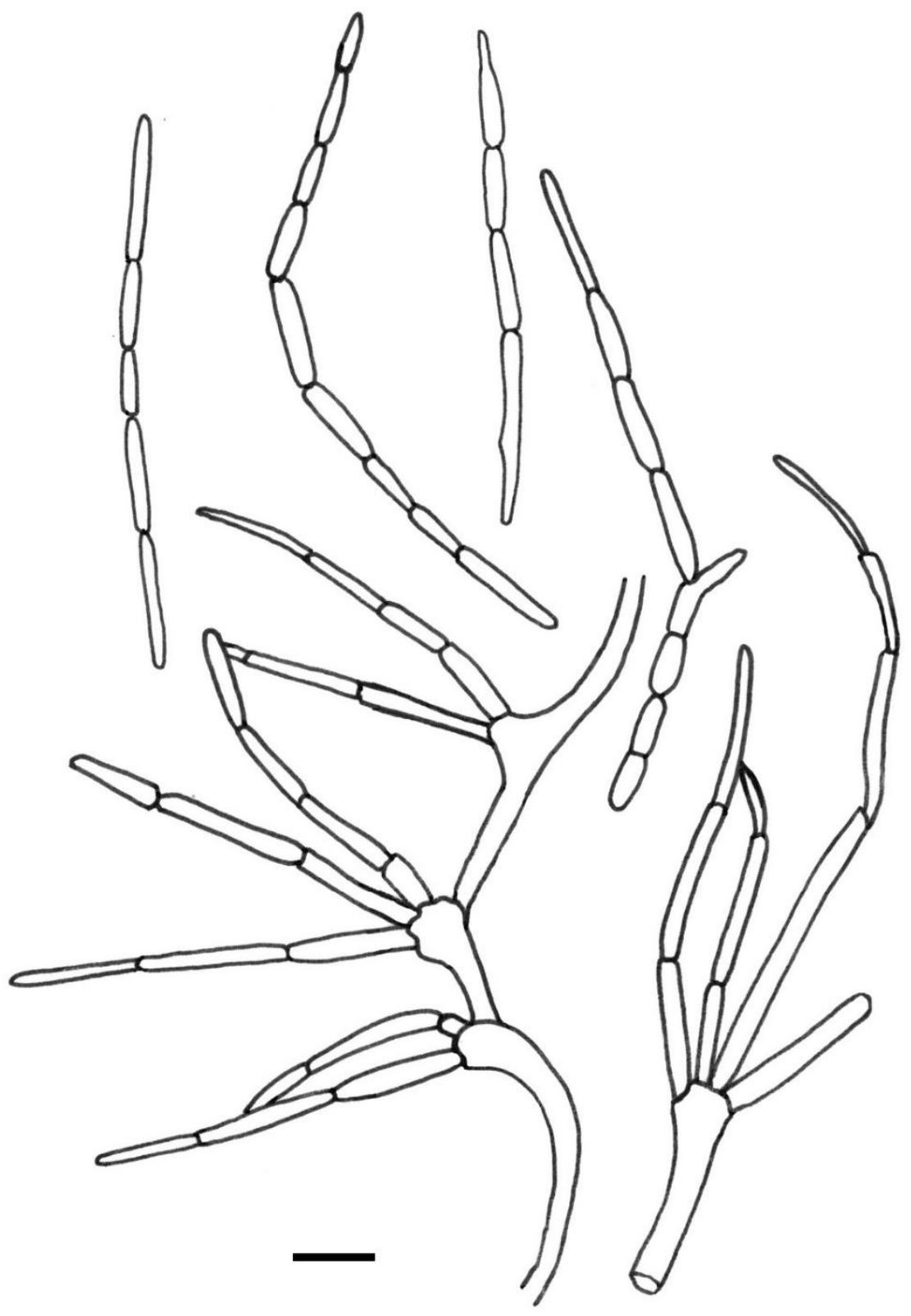

Figure 4 - Aphanophora eugeniae (CBS 124105, ex-type, redrawn from Crous et al. 2009). Conidiogenous cells with conidia. Scale bar: $10 \mu \mathrm{m}$.

Beelia F. Stevens \& R.W. Ryan, in Stevens, Bulletin of the Bernice P. Bishop Museum, Honolulu, Hawaii 19: 71 (1925)

Index Fungorum number: IF530, Facesoffungi number: FoF 10330, 3 morphological species (Species Fungorum 2021), molecular data unavailable.

Type species - Beelia suttoniae F. Stevens \& R.W. Ryan

Saprobic on the surface of leaves. Sexual morph: Ascomata superficial, immersed in darkened mycelium, globose to subglobose, black, ostiolate, periphysate. Wall of ascoma comprising two cell types, externally comprising pigmented, dark brown, thick-walled cells, with inner layer thinner and composed of hyaline, thin-walled cells. Hamathecium lacking paraphyses. Asci 8-spored, bitunicate, broadly ellipsoidal, obovate to saccate, pedicellate, with an ocular chamber. Ascospores cylindrical, 
hyaline, 5-septate, strongly constricted at each septum, smooth-walled, with a narrow mucilage sheath. Asexual morph: Undetermined.

Notes - Beelia was introduced by Stevens (1925) and typified by B. philippinensis Bat. \& C.A.A (Batista \& Costa 1959). Subsequently, B. plumeria Bat. \& Cavalc. was added to the genus (Batista et al. 1967). Beelia was accommodated in Microthyriaceae based on morphology by Stevens (1925) and confirmed by Petrak (1953). According to the dimidiate ascomata and long, brown ascospores, von Arx \& Müller (1975) transferred Beelia to Myriangiaceae. Recently, Beelia was regarded as a genus in Elsinoaceae (Hawksworth et al. 1995, Lumbsch \& Huhndorf 2007, Kirk et al. 2008). Li et al. (2011) and Hyde et al. (2013) suggested to transfer Beelia to Chaetothyriaceae because the taxon was a superficial biotroph on leaf surfaces, which fit the characters of Chaetothyriaceae. Beelia differs from other genera in this family as the ascospores are distoseptate, with a deep central constriction. Combined with important diagnostic characters of periphysate ostioles (von Arx \& Müller 1975), we retain Beelia in Chaetothyriaceae. DNA sequence data are needed to clarify the placement of Beelia.

Beelia suttoniae F. Stevens \& R.W. Ryan, Bulletin of the Bernice P. Bishop Museum, Honolulu, Hawaii 19: 71 (1925)

Fig. 5

Index Fungorum number: IF200511; Facesoffungi number: FoF 10331

Saprobic on the surface of leaves of Suttonia lanaiensis. Sexual morph: Ascomata 190-210 $\mu \mathrm{m}$ wide, 115-133 $\mu \mathrm{m}$ high, scattered, superficial, immersed in the darkened mycelial substrate, globose to subglobose, black, easily removed, ostiolate. Ostiole open, periphysate. Wall of ascoma 25-30 $\mu \mathrm{m}$ wide, up to $39 \mu \mathrm{m}$ wide at the apex, $20 \mu \mathrm{m}$ wide at the base, comprising multi-layers, externally comprising pigmented, dark brown, thick-walled cells of textura globulosa, with inner layer thinner, composed of lightly pigmented to hyaline, thin-walled cells of textura angularis. Hamathecium lacking paraphyses. Asci 70-89 × 45-55 $\mu \mathrm{m}(\overline{\mathrm{x}}=84.3 \times 51.2 \mu \mathrm{m}, \mathrm{n}=20)$, 8-spored, bitunicate, broadly ellipsoidal, obovate to saccate, thick-walled, with a small pointed pedicle, with an ocular chamber. Ascospores 38-45 $\times 13-18 \mu \mathrm{m}(\overline{\mathrm{x}}=42.8 \times 14.6 \mu \mathrm{m}, \mathrm{n}=20)$, irregularly arranged, cylindrical, hyaline, 5-septate, slightly constricted at each septum, central septum strongly constricted and upper part wider, smooth-walled, with a narrow mucilage sheath. Asexual morph: Undetermined.

Material examined - USA, Hawaii, on leaves of Suttonia lanaiensis Mez (Myrsinaceae), 1925, Lanai, no. 421, leg. Munro (BISH 499845, syntype).

Camptophora Réblová \& Unter., PLoS ONE 8(5): e63547, 14 (2013)

Index Fungorum number: IF803679, Facesoffungi number: FoF 10332, 2 species with molecular data.

Type species - Camptophora hylomeconis (Crous, de Hoog \& H.D. Shin) Réblová \& Unter.

Saprobic on sugar exudates from insects or foliar epiphytes on the upper surface of living leaves. Sexual morph: Mycelium superficial, black, composed of dark brown, reticulate-branched, hyphae, constricted at the septa. Ascomata scattered, superficial, subglobose to globose, black, with short stalk. Wall of ascoma multi-layered, inwardly hyaline of textura prismatica, dark brown towards the outside, comprised textura angularis. Asci 8-spored, bitunicate, ovoid to obpyriform, short pedicellate. Ascospores biseriate, fusiform, hyaline, phragmospores or muriform, with 3-5 transverse septa and 1-4 longitudinal septa, constricted at the septum, with guttules, narrow at the ends (Yang et al. 2018). Asexual morph: Mycelium composed of branched, septate, greenish-brown hyphae. Conidiophores lacking, reduced to a conidiogenous cell. Conidiogenous cells phialidic, intercalary, hyaline, with inconspicuous collarette, or sometimes proliferating percurrently. Conidia sickle-shaped, light brown, usually 3-septate, constricted at the septa, curved, widest in middle, apex rounded, base subtruncate, with a foot cell for germination, smooth-walled, guttulate (Crous et al. 2007, Réblová et al. 2013).

Notes - Camptophora Réblová \& Unter. was established to accommodate Camptophora hylomeconis (Crous, de Hoog \& H.D. Shin) Réblová \& Unter. transferred from Cyphellophora (Réblová et al. 2013). The genus is characterized by phialidic, intercalary, conidiogenous cells, with an inconspicuous collarette, or sometimes proliferating percurrently, and sickle-shaped conidia (Crous et 
al. 2007, Réblová et al. 2013). Phylogenetically, C. hylomeconis, Aphanophora eugeniae (Crous \& Alfenas) Réblová \& Unter. and Fumagopsis stellae Crous \& A.J. Carnegie group together within Chaetothyriaceae (Réblová et al. 2013, this study, Fig. 1). However, Camptophora has conspicuous phialides, with a single conidiogenous locus and sickle-shaped conidia, while A. eugeniae has inconspicuous collarettes, with aggregated loci and subcylindrical to cylindrical conidia, and it is apparently differentiated from $F$. stellae based on star-like conidia (Crous et al. 2007, 2018, Réblová et al. 2013). Yang et al. (2018) reported a sexual morph of $C$. schimae H. Yang \& K.D. Hyde associated with sugar exudates from insects.
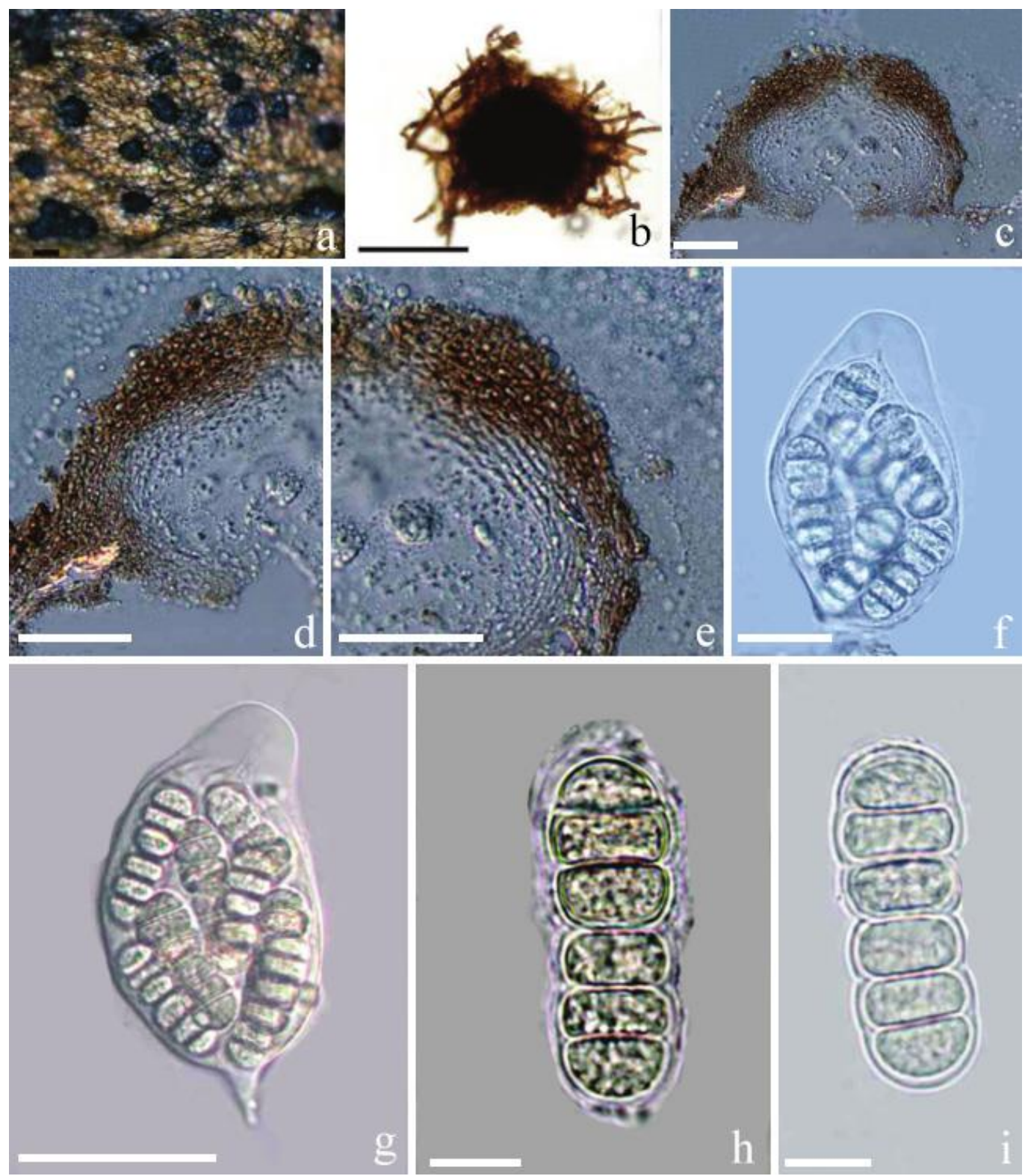

Figure 5 - Beelia suttoniae (BISH 499845, syntype). a Appearance of ascomata on host leaf with darkened mycelium. b Squash of ascoma in water. c Vertical section of ascoma. d-e Vertical section through ascoma wall. f, $g$ Asci with ascospores. h, i Ascospores. Scale bars: $b=100 \mu \mathrm{m}, \mathrm{c}-\mathrm{e}, \mathrm{g}=50$ $\mu \mathrm{m}, \mathrm{f}=25 \mu \mathrm{m}, \mathrm{h}=\mathrm{i}=10 \mu \mathrm{m}$.

Camptophora hylomeconis (Crous, de Hoog \& H.D. Shin) Réblová \& Unter., PLoS ONE 8(5): e63547, 14 (2013)

三 Cyphellophora hylomeconis Crous, de Hoog \& H.D. Shin, Stud. Mycol. 58: 200 (2007)

Index Fungorum number: IF803680; Facesoffungi number: FoF 10333

Description - see Crous et al. (2007), Réblová et al. (2013) and Yang et al. (2018) 
Type material - Korea, Yangpyeong, on leaves of Hylomecon verlance Maxim. (Papaveraceae), 4 June 2003, H.D. Shin (CBS 113311, ex-type).

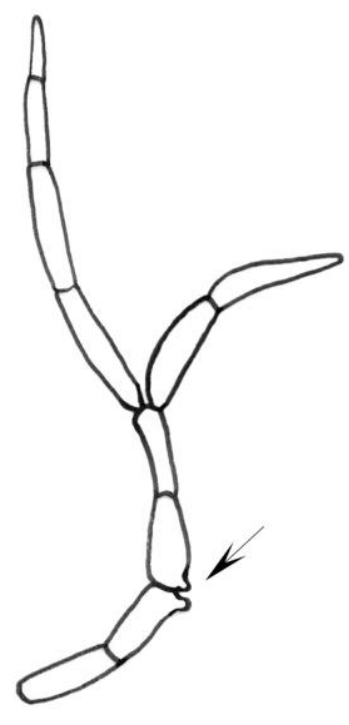

a

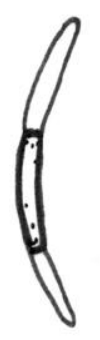

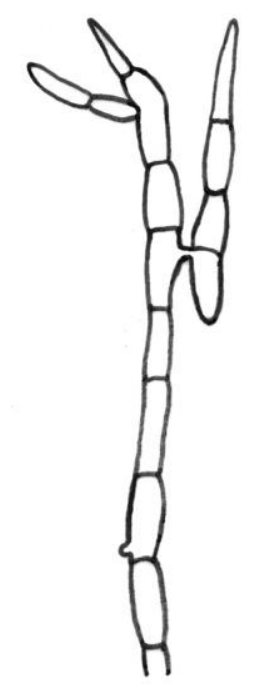

b

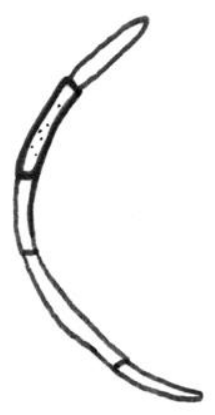

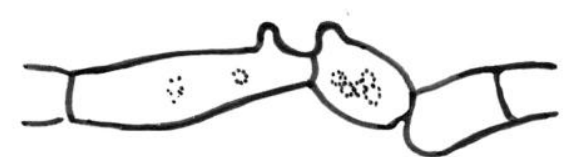

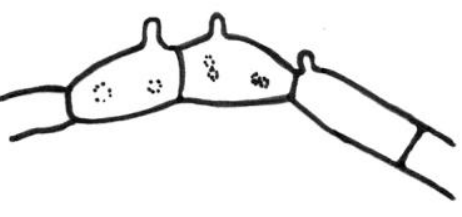

C

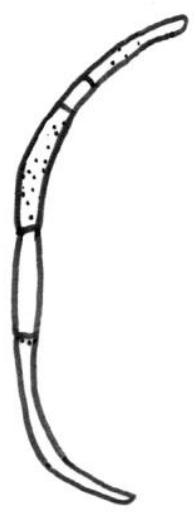

d

Figure 6 - Camptophora hylomeconis (redrawn from Crous et al. 2007, ex-type). a Phialides with conidia. b Anastomosing conidia. c Phialidic loci that can proliferate percurrently above the collarette. d Conidia. Scale bar: $10 \mu \mathrm{m}$.

Ceramothyrium Bat. \& H. Maia, Publicações Inst. Micol. Recife 23(1-3): 5 (1956)

Index Fungorum number: IF880, 36 morphological species (Species Fungorum 2021), 11 species with molecular data.

Type species - Ceramothyrium paiveae Bat. \& H. Maia

Epiphytic on leaves. Mycelium superficial, elongate, brownish, septate, with dark mycelium without penetrating host tissues. Sexual morph: Ascomata superficial, solitary, scattered, pale brown, globose to subglobose. Wall of ascoma composed of multi-layers, externally comprising pigmented, dark brown, thick-walled cells, with inner layer thinner composed of hyaline, thin-walled cells. 
Hamathecium lacking paraphyses. Asci 8-spored, bitunicate, broadly obovoid, short pedicellate, apically rounded, with an ocular chamber. Ascospores overlapping, irregularly triseriate, oblong to ellipsoid, hyaline, muriform, slightly constricted at the septa, smooth-walled, with a mucilaginous sheath. Asexual morph: Undetermined.

Notes - Ceramothyrium species have similar characters and ecological habitats to other sooty mould genera in Capnodiaceae (Chomnunti et al. 2012b, 2014). Ceramothyrium is characterized by ascomata covered by a subiculum, with a circumferential space around the maturing ascomata and at times with olivaceous to fuscous hyphae (Batista \& Maia 1956, Hughes 1976, Chomnunti et al. 2012). Ceramothyrium resembles Phaeosaccardinula but ascospores of Ceramothyrium are not muriform. Most species were introduced based solely on morphological data. Winka et al. (1998) placed Ceramothyrium in Chaetothyriaceae with molecular data and this classification was confirmed by subsequent studies (Lutzoni et al. 2004, Miadlikowska \& Lutzoni 2004, Reeb et al. 2004, Chomnunti et al. 2012a, b, 2014, Yang et al. 2014, Hongsanan et al. 2015, Zeng et al. 2016). Although there is a large number of species in Ceramothyrium with molecular data showing Ceramothyrium clusters in Chaetothyriaceae (Chaetothyriales), there is no molecular data for the type species $C$. paiveae. Hence, based on morphological comparison of collection of Ceramothyrium and phylogenetic analysis (Fig. 1), Ceramothyrium is maintained in Chaetothyriaceae.

Ceratocarpia Rolland, Bull. Soc. mycol. Fr. 12(1): 2 (1896)

Index Fungorum number: IF884, Facesoffungi number: FoF 10334, 2 morphological species (Species Fungorum 2021), molecular data unavailable.

Saprobic on branches or twigs in terrestrial habitats. Sexual morph: Ascomata dense, gregarious, sub-immersed to erumpent, globose to subglobose. Ostiole inconspicuous. Wall of ascoma comprising two cell types, externally comprising pigmented, dark brown, thick-walled cells and inner layer thinner, composed of lightly pigmented to hyaline, thin-walled cells. Hamathecium composed of filiform, long, septate pseudoparaphyses. Asci 8-spored, bitunicate, fissitunicate, clavate to broadly clavate, pedicellate. Ascospores irregularly arranged, ellipsoid to fusiform, dictyosporous, constricted at the central septum, light brown to brown, with a long germ tube-like protuberance at each end, smooth and thick-walled, lacking a gelatinous sheath or appendages. Asexual morph: Undetermined.

Type species - Ceratocarpia cactorum Rolland

Notes - Ceratocarpia is characterized by dark mycelium adpressed to the host cuticle, ascomata forming beneath an external hyphal mat, lack of setae, bitunicate or fissitunicate asci, and muriform, light brown ascospores (Rolland 1896). The genus was placed in Dothideomycetes, genera incertae sedis by Lumbsch \& Huhndorf (2010). Ceratocarpia is similar to Chaetothyrium as both have similar glabrous ascomata, muriform ascospores and evanescent pseudoparaphyses, while Ceratocarpia has light brown to brown, muriform ascospores with long germ tube-like protuberance at each end, and Chaetothyrium has hyaline, septate or muriform ascospores. Tian et al. (2014) suggested to accommodate Ceratocarpia in Chaetothyriaceae. We agree with Tian et al. (2014) and retain Ceratocarpia within Chaetothyriaceae based on morphology.

Ceratocarpia cactorum Rolland, Bull. Soc. mycol. Fr. 12(1): 2 (1896)

Fig. 7

Index Fungorum number: IF217302; Facesoffungi number: FoF 10335

Saprobic on branches of Erica sp. in terrestrial habitats. Sexual morph: Ascomata 100-235 × 110-190 $\mu \mathrm{m}(\overline{\mathrm{x}}=169 \times 128 \mu \mathrm{m}, \mathrm{n}=10)$, dense, gregarious, sub-immersed in the thallus of the dark brown or black subiculum, not easily removed, globose to subglobose. Ostiole inconspicuous. Wall of ascoma $22-35 \mu \mathrm{m}(\overline{\mathrm{x}}=31 \mu \mathrm{m}, \mathrm{n}=10)$ wide, comprising two layers, externally comprising pigmented, dark brown, thick-walled cells of textura globulosa, with inner layer thinner, composed of lightly pigmented to hyaline, thin-walled cells of textura angularis. Hamathecium $1.3-2 \mu \mathrm{m}$ in width $(\overline{\mathrm{x}}=1.5$ $\mu \mathrm{m}, \mathrm{n}=10$ ), composed of filiform, long, septate pseudoparaphyses, asci embedded in mucilage matrix. Asci 30-65 × 12-32 $\mu \mathrm{m}(\overline{\mathrm{x}}=41 \times 18 \mu \mathrm{m}, \mathrm{n}=10), 8$-spored, bitunicate, fissitunicate, clavate to broadly clavate, pedicellate, lacking a distinct ocular chamber. Ascospores $20-32 \times 8-11 \mu \mathrm{m}(\overline{\mathrm{x}}=27 \times 10 \mu \mathrm{m}$, $\mathrm{n}=10$ ), bi-seriate or multi-seriate, irregularly arranged, ellipsoid to fusiform, dictyosporous, constricted 
at the central septum, light brown to brown, with up to $4 \mu \mathrm{m}$ long germ tube-like protuberances at each end, smooth and thick-walled, lacking a gelatinous sheath or appendages. Asexual morph: Undetermined.

Material examined - France, La Molle: Var, in the branches of Erica sp. (Ericaceae), April 1911, G. Arnaud (S F46332).

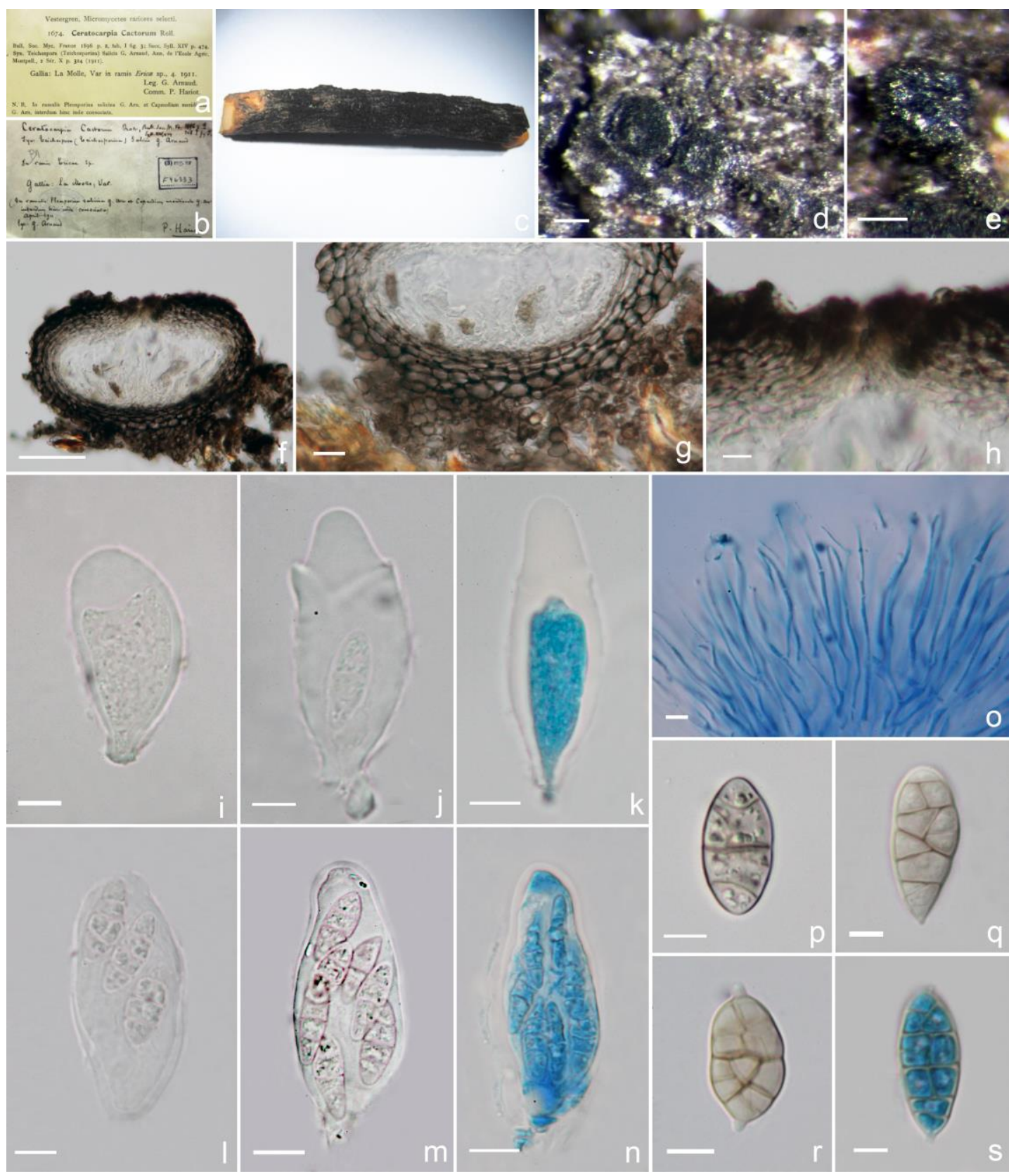

Figure 7 - Ceratocarpia cactorum (S! F46332). a, b Envelop and collection information of Ceratocarpia cactorum. c Herbarium material. d, e Appearance of ascomata on the branches of Erica sp.. f Vertical section of ascoma. g Vertical section through ascoma wall. h Vertical section through ostiole. i, j, l, m Asci with ascospores. $\mathrm{k}, \mathrm{n}$ Asci and ascospores, stained in lactophenol cotton blue reagent. o Hamathecium, stained in lactophenol cotton blue reagent. $\mathrm{p}-\mathrm{r}$ Ascospores. $\mathrm{s}$ Ascospores, stained in lactophenol cotton blue reagent. Scale bars: $\mathrm{d}, \mathrm{e}=100 \mu \mathrm{m}, \mathrm{f}=50 \mu \mathrm{m}, \mathrm{g}, \mathrm{h}=20 \mu \mathrm{m}, \mathrm{i}-\mathrm{n}=10$ $\mu \mathrm{m}, \mathrm{o}-\mathrm{s}=5 \mu \mathrm{m}$.

Chaetothyriomyces Pereira-Carv., Inácio \& Dianese, Mycotaxon 107: 484 (2009)

Index Fungorum number: IF512105, Facesoffungi number: FoF 10336, 1 species (Species Fungorum 2021), molecular data unavailable. 
Type species - Chaetothyriomyces brasiliensis Pereira-Carv.

Epiphytic on living leaves in terrestrial habitats. Colonies effuse, superficial. Mycelium superficial, branches, septate, brown to dark brown. Sexual morph: Ascomata dense, gregarious, superficial, globose to subglobose, brown to dark brown, smooth-walled. Ostiole lacking. Wall of ascoma comprising two cell types, externally comprising pigmented, dark brown, thick-walled cells of textura globulosa and inner layer thinner, composed of lightly pigmented to hyaline, thin-walled cells of textura angularis. Hamathecium lacking paraphyses. Asci 16-spored, bitunicate, fissitunicate, broadly clavate, pedicellate. Ascospores irregularly arranged, ellipsoid to fusiform, hyaline, 1-septate, smoothwalled, lacking a gelatinous sheath or appendages. Asexual morph: Undetermined (Pereira-Carvalho et al. 2009).

Notes - The monotypic genus Chaetothyriomyces was introduced by Pereira-Carvalho et al. (2009) with C. brasiliensis Pereira-Carv. et al. as the type species and accommodated in Chaetothyriaceae. Species of Chaetothyriomyces are characterized by superficial ascoma with mycelium containing septate hyphae covering, broadly clavate, 16-spored asci and ellipsoid to fusiform ascospores. No asexual morph is linked to this genus (Pereira-Carvalho et al. 2009). With the unique 16-spored asci, we maintain this genus in Chaetothyriaceae pending fresh collection and DNA sequence data.

Chaetothyriomyces brasiliensis Pereira-Carv., Inácio \& Dianese, Mycotaxon 107: 484 (2009)

Fig. 8

Index Fungorum number: IF512643; Facesoffungi number: FoF 10337

Description: see Pereira-Carvalho et al. (2009)

Type material - Brazil, Mato Grosso do Sul, Campo Grande, Reserva Ecológica da Embrapa at Depate Empaer, on living leaves of Qualea grandiflora Mart. (Vochysiaceae), 16 April 1996, M. Sanchez 1892 (UB Col. Micol. 12116, holotype).
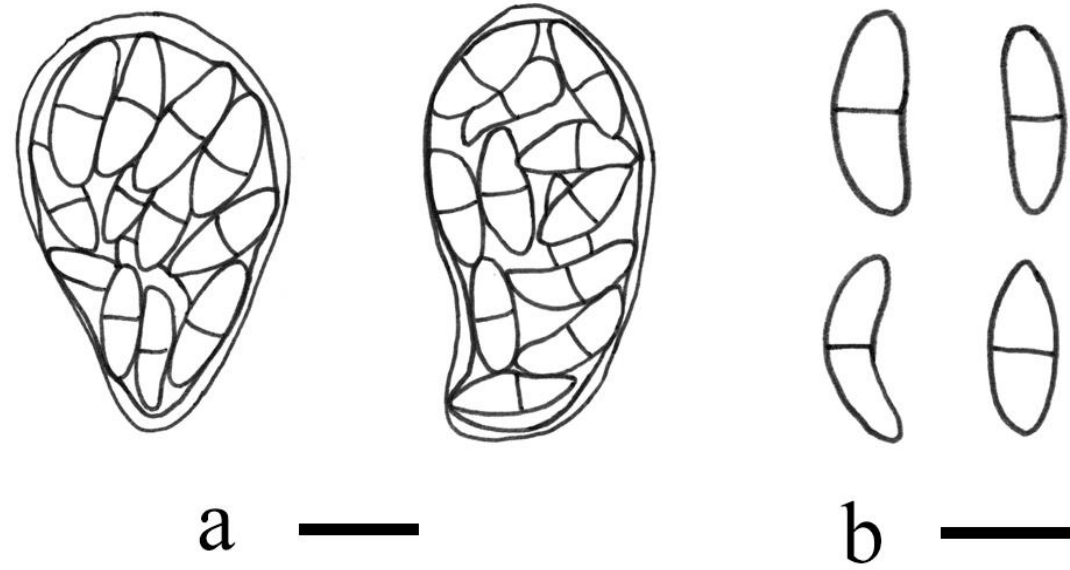

Figure 8 - Chaetothyriomyces brasiliensis (UB Col. Micol. 12116, holotype, redrawn from PereiraCarvalho et al. 2009). a Broadly clavate, 16-spored asci. b Ellipsoid to fusiform, 1-septate ascospores. Scale bars: $10 \mu \mathrm{m}$.

Cyphellophoriella Crous \& A.J. Sm., Sydowia 67: 95 (2015)

Index Fungorum number: IF812524, Facesoffungi number: FoF 10338, 1 species with molecular data.

Type species - Cyphellophoriella pruni Crous \& A.J. Sm.

Epiphytic on healthy living leaves. Sexual morph: Undetermined. Asexual morph: Mycelium composed of branched, septate, pale brown hyphae. Conidiophores reduced to conidiogenous cells on hyphae. Conidiogenous cells phialidic, in a flower-like arrangement, intercalary, brown, inconspicuous collarette, forming an outer tent-like collarette surrounding the conidiogenous cells, brown, verruculose. 
Conidia solitary, fusiform to filiform, hyaline to pale brown, curved, obtuse at the apex, truncate at the base, smooth-walled (Crous et al. 2015b).

Notes - The monotypic genus Cyphellophoriella was introduced to accommodate a cyphellophora-like species and placed in Chaetothyriaceae by Crous et al. (2015b). It is characterized by phialides formed directly on hyphae, petal-like conidiogenous cells and curved conidia (Crous et al. 2015b). The key distinction between Cyphellophoriella and other genera is its flower-like arrangement of conidiogenous cells on a mother cell. Based on the differences in ITS sequence, Cyphellophoriella was clarified as a new genus (Crous et al. 2015b). In our phylogenetic analyses combined LSU and ITS (Fig. 1), Cyphellophoriella is not congeneric to Cyphellophora (Cyphellophoraceae), but resides in Chaetothyriaceae with a distinct clade affinity to Ceramothyrium, Chaetothyrium and Nullicamyces. Thus, Cyphellophoriella is accepted as a distinct genus in Chaetothyriaceae.

Cyphellophoriella pruni Crous \& A.J. Sm., Sydowia 67: 96 (2015)

Fig. 9

Index Fungorum number: IF812525; Facesoffungi number: FoF 10339

Description - see Crous et al. (2015b)

Type material - USA, California, Berkeley, on an apparently healthy leaf of Prunus sp. (Rosaceae), 26 March 2014, A. J. Smith (CBS 140001, ex-type).

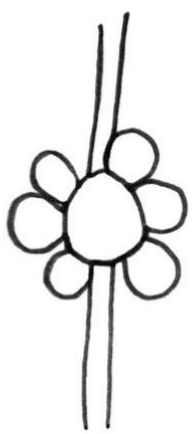

a
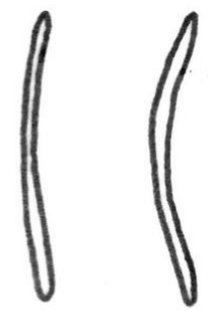
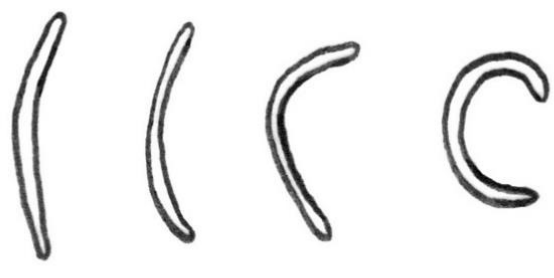

C

Figure 9 - Cyphellophoriella pruni (CBS 140001, ex-type, redrawn from Crous et al. 2015b). a Flower-like conidiogenous cells. b Subcylindrical to ampulliform conidiogenous cells with conidia. c Conidia. Scale bars: $10 \mu \mathrm{m}$.

Longihyalospora D.S. Tennakoon, C.H. Kuo \& K.D. Hyde, MycoKeys 61 (2019)

Index Fungorum number: IF556715, Facesoffungi number: FoF 06136, 2 species with molecular data.

Type species - Longihyalospora ampeli D.S. Tennakoon, C.H Kuo \& K.D. Hyde, MycoKeys 61: 100 (2019)

Description: see Tennakoon et al. (2019)

Notes - Longihyalospora was introduced by Tennakoon et al. (2019) with L. ampeli (the type species) and a new combination L. vermisporum (Hansf.) Tennakoon, C.H. Kuo \& K.D. Hyde. Species 
of Longihyalospora are characterized by a dark mycelium covering the upper leaf surface, an elongate mycelial pellicle, a ring of setae around the pellicle, broadly obovoid, short pedicellate asci and hyaline, elongate fusiform and 8-11-septate ascospores, with a thin mucilaginous sheath. Phylogenetically, Longihyalospora formed a single sub-clade with strong support (Tennakoon et al. 2019). Longihyalospora resembles Chaetothyrium, but the two genera can be distinguished by morphology, such as the colour of hyphae, size and shape of asci and ascospores (Spegazzini 1888, Hansford 1946, Tennakoon et al. 2019).

Nullicamyces Crous, Persoonia 40: 361 (2018)

Index Fungorum number: IF825417, 1 species with molecular data.

Type species - Nullicamyces eucalypti Crous, Persoonia 40: 361 (2018)

Description - see Crous et al. (2018)

Notes - The key distinction between Nullicamyces and other genera is that Nullicamyces has dimorphic morphology, forming matsushimaea-like (conidia ellipsoid, aseptate, forming acropetal chains of conidia, appearing star-shaped with radiating arms) and pseudocercospora-like (Conidia long flexuous, obclavate, multiseptate, frequently giving rise to secondary) asexual morphs in culture. Based on the differences in ITS sequence data. Nullicamyces was confirmed as a new genus (Crous et al. 2018). Nullicamyces shows a sister relationship with Ceramothyrium in Chaetothyriaceae (Fig. 1).

Phaeosaccardinula Henn., Hedwigia 44: 67 (1905)

Index Fungorum number: IF3943, Facesoffungi number: FoF 04392, 27 morphological species (Species Fungorum 2021), 4 species with molecular data.

Epiphytic on the surface of leaves forming a sooty-like coating. Mycelium superficial, black, composed of dark brown to black, reticulate to branched, septate hyphae. Sexual morph: Ascomata superficial, scattered, globose to subglobose, cupulate when dry, dark brown to black, with or without setae, thick-walled cells at the outside, ostiolate or ostiole inconspicuous. Wall of ascoma multi-layered, composed of brown, thick-walled cells outside, becoming light brown and flattened in the inner region. Hamathecium lacking paraphyses, or paraphyses hyaline, aseptate. Asci 4-8-spored, bitunicate, oblongellipsoid, clavate, subglobose to oval, sessile or short pedicellate, early evanescent, lacking an ocular chamber when mature. Ascospores overlapping 2-4-seriate, hyaline, olivaceous-green at the septa of mature ascospores, oblong-ellipsoid, muriform, constricted at the septa, with a mucilaginous sheath. Asexual morph: Undetermined.

Type species - Phaeosaccardinula diospyricola Henn.

Notes - Phaeosaccardinula is characterized by its superficial ascomata, formed beneath a layer that attaches the ascomata to the host surface and muriform ascospores. Species of Phaeosaccardinula were later transferred to Limacinula and Treubiomyces (Reynolds 1971, 1983). In our study Phaeosaccardinula ficus (MFLUCC 10-0009) clustered in Chaetothyriaceae without support. Hence, based on morphological comparison of other Phaeosaccardinula species and phylogenetic analysis (Fig. 1), the genus is retained in Chaetothyriaceae pending new sequence data.

Phaeosaccardinula diospyricola Henn., Hedwigia 44: 67 (1905)

Index Fungorum number: IF156465; Facesoffungi number: FoF 10340

Fig. 10

Epiphytic on the upper surface of living leaves of Diospyros sp. forming a sooty-like coating. Mycelium 3-6 $\mu \mathrm{m}$ wide $(\overline{\mathrm{x}}=5.2 \mu \mathrm{m}, \mathrm{n}=20)$, superficial, black, composed of dark brown to black, reticulate to branched, septate hyphae. Sexual morph: Ascomata 165-235 × 125-190 $\mu \mathrm{m}(\overline{\mathrm{x}}=197 \times$ $162 \mu \mathrm{m}, \mathrm{n}=10$ ), superficial, scattered, globose to subglobose, cupulate when dry, dark brown to black, lacking setae, thick-walled, ostiole inconspicuous. Wall of ascoma 20-35 $\mu \mathrm{m}$ wide, multi-layered, externally comprising pigmented, dark brown, thick-walled cells of textura globulosa, with inner layer thinner, composed of lightly pigmented to hyaline, thin-walled cells of textura prismatica. Hamathecium lacking paraphyses. Asci $42-58 \times 28-36 \mu \mathrm{m}(\overline{\mathrm{x}}=52 \times 32 \mu \mathrm{m}, \mathrm{n}=10)$, 6-8-spored, bitunicate, oblong-ellipsoid, clavate when young, subglobose to oval when mature, sessile or short pedicellate, early evanescent, lacking an ocular chamber when mature. Ascospores 55-62 $\times 6-9 \mu \mathrm{m}(\overline{\mathrm{x}}$ 
$=58 \times 8 \mu \mathrm{m}, \mathrm{n}=10$, overlapping 2-4-seriate, hyaline, olivaceous green at the septa of mature ascospores, oblong-ellipsoid, muriform, with 7-9 transverse septa and 3-5 longitudinal septa, constricted at the septa, with a mucilaginous sheath. Asexual morph: Undetermined.

Material examined - Peru, Rio Amazonas, Tarapoto, on leaves of Diospyros sp. (Ebenaceae), September 1902, E. Ule 6471 (S-F9582, isotype).
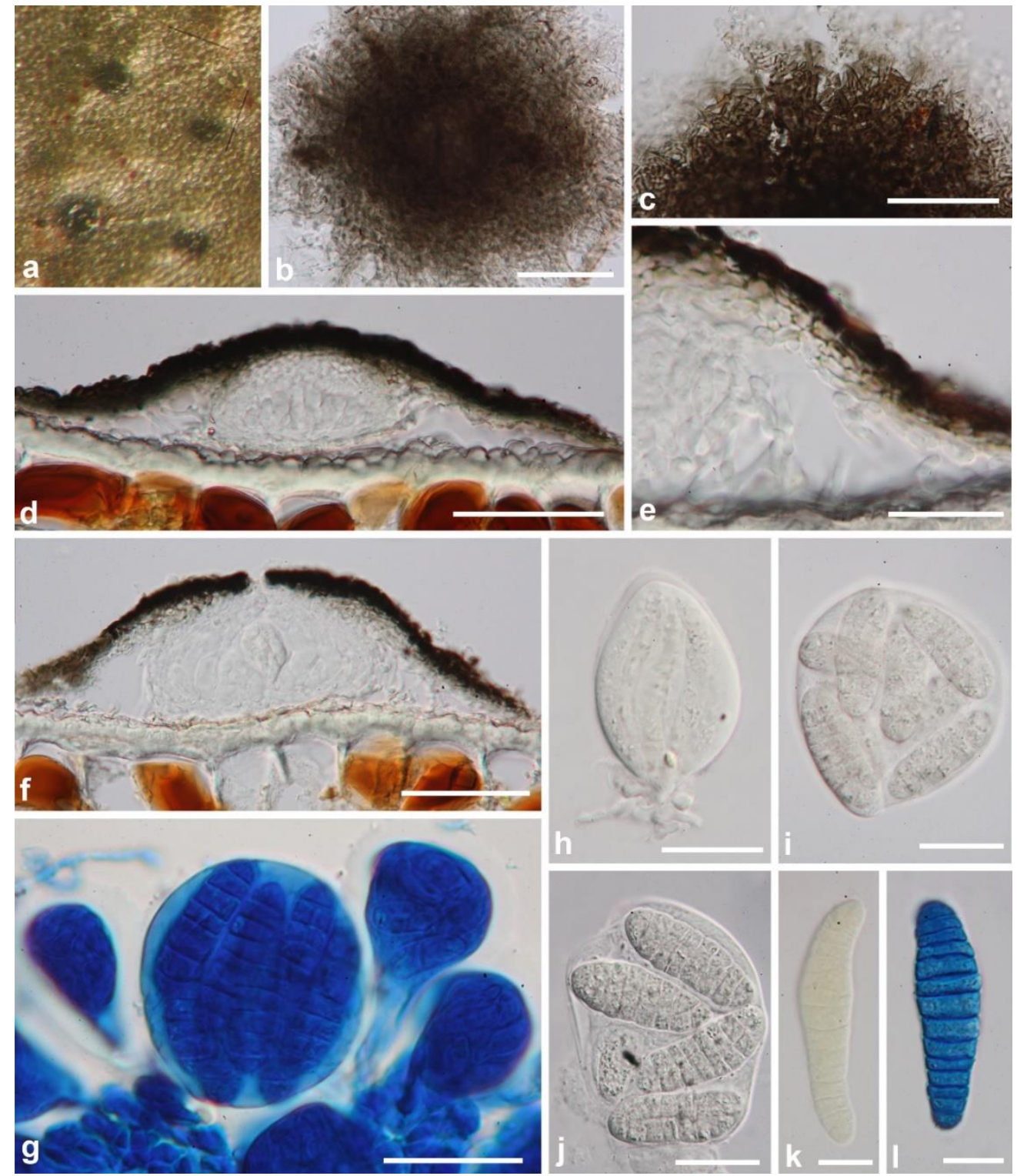

Figure 10 - Phaeosaccardinula diospyricola (S-F9582, isotype). a Appearance of superficial ascomata on the host surface. b, c Squash mount of ascoma. d, f Vertical sections of ascomata. e Vertical section through ascoma wall. g Asci with ascospores, stained in lactophenol cotton blue reagent. $\mathrm{h}-\mathrm{j}$ Asci with ascospores. $\mathrm{k}$ Ascospores. 1 Ascospores, stained in lactophenol cotton blue reagent. Scale bars: b, c, g = $50 \mu \mathrm{m}, \mathrm{d}, \mathrm{f}=100 \mu \mathrm{m}, \mathrm{e}, \mathrm{h}-\mathrm{j}=20 \mu \mathrm{m}, \mathrm{k}, \mathrm{l}=10 \mu \mathrm{m}$.

Phaeosaccardinula malloti (Rehm) Theiss., in Theissen \& Sydow, Annls mycol. 15(6): 481 (1918) [1917]

三Limacinula malloti Rehm, Philipp. J. Sci., C, Bot. 8(5): 395 (1913)

Fig. 11

For synonyms see Species Fungorum

Index Fungorum number: IF156268; Facesoffungi number: FoF 10341

Epiphytic on the upper surface of living leaves of Mallotus philippensis, forming a sooty-like coating. Mycelium 4-6 $\mu \mathrm{m}$ wide $(\overline{\mathrm{x}}=5.3 \mu \mathrm{m}, \mathrm{n}=20)$, superficial, black, composed of dark brown to black, reticulate to branched, septate hyphae. Sexual morph: Ascomata 135-250 $\mu \mathrm{m}$ diam $(\overline{\mathrm{x}}=220 \mu \mathrm{m}$, 
$\mathrm{n}=10$ ), superficial, scattered, globose to subglobose, cupulate when dry, dark brown to black, lacking setae, thick-walled, ostiolate. Ostiole in the center, periphysate or apapillate. Wall of ascoma 25-42 $\mu \mathrm{m}$ wide, multi-layered, externally comprising pigmented, dark brown, thick-walled cells of textura globulosa, with inner layer thinner, composed of lightly pigmented to hyaline, thin-walled cells of textura prismatica. Hamathecium lacking paraphyses. Asci $80-110 \times 18-32 \mu \mathrm{m}(\overline{\mathrm{x}}=103 \times 28 \mu \mathrm{m}, \mathrm{n}=$ 10), 8-spored, bitunicate, oblong-ellipsoid, broadly clavate, subglobose to oval when young, short pedicellate, early evanescent, lacking an ocular chamber when mature. Ascospores 18-24 $\times 6-9 \mu \mathrm{m}(\overline{\mathrm{x}}$ $=20 \times 8 \mu \mathrm{m}, \mathrm{n}=10$ ), overlapping 2-4-seriate, hyaline, olivaceous-green at the septa of mature ascospores, oblong-ellipsoid, muriform, with 4-7 transverse septa and 4-6 longitudinal septa, constricted at the septa, rounded at both ends, with a mucilaginous sheath. Asexual morph: Undetermined.

Material examined - Philippines, Los Baños, on leaves of Mallotus philippensis (Lam.) Müll. Arg. (Euphorbiaceae), March 1913, C. F. Baker (PC0084486, holotype).

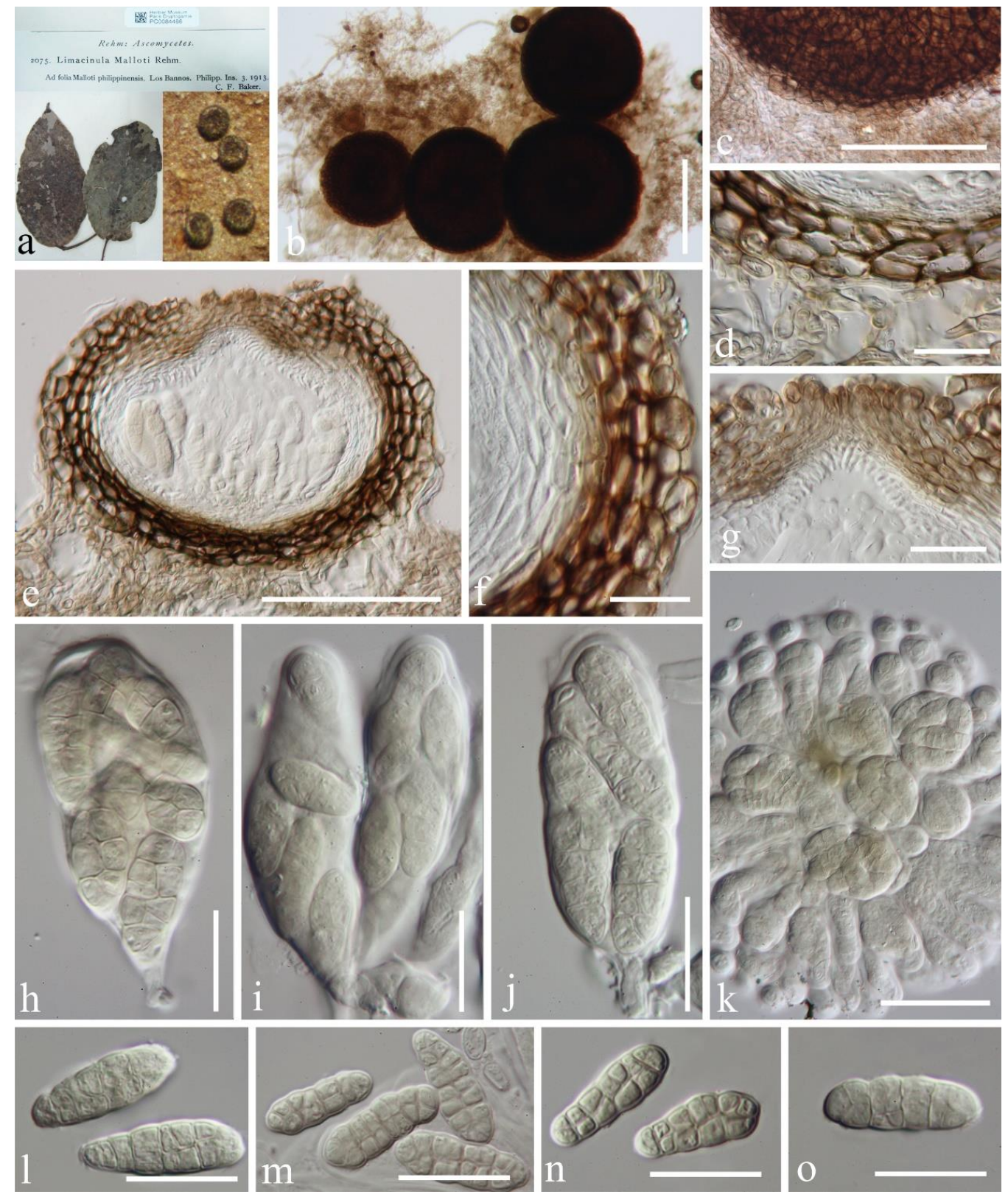

Figure 11 - Phaeosaccardinula malloti (PC0084486, holotype). a Herbarium material, with superficial ascomata on the host. b, c Squash mounts of ascomata. d, f Vertical section through peridium. e Vertical sections of ascoma. $\mathrm{g}$ Vertical section through ostiole. $\mathrm{h}-\mathrm{k}$ Asci with ascospores. $\mathrm{l}-\mathrm{O}$ Ascospores. Scale bars: $\mathrm{b}=200 \mu \mathrm{m}, \mathrm{c}, \mathrm{e}=100 \mu \mathrm{m}, \mathrm{d}, \mathrm{f}, \mathrm{g}, \mathrm{h}-\mathrm{j}, \mathrm{l}-\mathrm{o}=20 \mu \mathrm{m}, \mathrm{k}=50 \mu \mathrm{m}$. 
Treubiomyces Höhn., Sber. Akad. Wiss. Wien, Math.-naturw. Kl., Abt. 1 118: 1180 (1909)

Index Fungorum number: IF5532, Facesoffungi number: FoF 10342, 7 morphological species (Species Fungorum 2021), molecular data unavailable.

Epiphytic on leaves of various plants in terrestrial habitats. Mycelium superficial, black, composed of thin, branched to reticulate, membranous, hyaline, septate hyphae. Sexual morph: Ascostromata solitary to gregarious, globose-flattened, setose, with periphysate ostioles. Wall of ascoma composed of several layers of hyaline to light brown flattened cells of textura globulosa. Hamathecium lacking paraphyses. Asci 8-spored, bitunicate, fissitunicate, clavate, sessile, with a conspicuous refractive ring, thickened at the apex. Ascospores overlapping multi-seriate, cylindrical to oblong, hyaline, muriform, with or without a gelatinous sheath. Asexual morph: Undetermined (Batista \& Ciferri 1962, Pohlad et al. 1989).

Type - Treubiomyces pulcherrimus Höhn.

Notes - Treubiomyces is characterized by globose-flattened, setose, periphysate ostiole, bitunicate clavate asci and cylindrical to oblong, muriform ascospores (Batista \& Ciferri 1962, Pohlad \& Reynol 1974). Treubiomyces has been recognized as a genus in Capnodiaceae (Theissen 1913, Theissen \& Sydow 1917, Petrak 1929, Arnaud 1930, Fraser 1935, Eriksson 1981, Reynolds 1983). Treubiomyces pulcherritnus resembles Chaetothyrium in having superficial mycelia appressed to the host surface with globose ascomata developing beneath a mycelial shield, periphysate ostioles, and bitunicate asci, but differs in its muriform ascospores. Thus, Fisher (1939), Hansford (1946), Batista \& Ciferri (1957, 1962), Luttrell (1973), von Arx \& Müller (1975), Hughes (1976) and Barr (1979) assigned Treubiomyces to Chaetothyriaceae based on morphology. Herein, we accept Treubiomyces in Chaetothyriaceae pending epitypification. Treubiomyces is unique in this family in having muriform ascospores and setose ascomata.

Treubiomyces pulcherrimus Höhn., Sber. Akad. Wiss. Wien, Math. -naturw. Kl., Abt. 1 118: 1181 (1909)

Index Fungorum number: IF149202; Facesoffungi number: FoF 10343

Fig. 12

Type material - Indonesia, Java, on Ficus sp. (Moraceae) (holotype).

Vonarxia Bat., Publicações Inst. Micol. Recife 283: 5 (1960)

Index Fungorum number: IF10422, Facesoffungi number: FoF 10344; 2 morphological species (Species Fungorum 2021), 1 species with molecular data.

Epiphytic on leaves of various plants in terrestrial habitats. Sexual morph: Undetermined. Asexual morph: Mycelium immersed to superficial, composed of branched to reticulate, hyaline, pale to medium brown, septate hyphae. Conidiomata pycnidial, superficial, globose, setose, membranous. Setae irregularly scattered, simple, subulate with a bulbous base, dark brown, smooth to slightly roughwalled. Conidiogenous cells aggregated, doliiform to ellipsoid, hyaline or pale brown, from the upper cell of conidioma, sympodial proliferation. Conidia filiform, hyaline, aseptate or 1-septate, subcylindrical to clavate to doliiform at the base and upper three arms subcylindrical to cylindrical, 310-septate (Batista et al. 1960, Crous et al. 2009).

Type species - Vonarxia anacardii Bat. \& J.L. Bezerra

Notes - Vonarxia is characterized by pycnidial conidiomata, with subulate setae, doliiform to ellipsoid conidiogenous cells, sympodial proliferation, and filiform conidia with subcylindrical to doliiform base and upper three arms subcylindrical to cylindrical, multi-septate. Nag Raj (1977) commented that these fruiting bodies may be a sexual morph which he regarded as Kazulia. However, Kazulia was subsequently synonymized under Vonarxia (Aa van der \& van Oorschot 1985, Aa van der \& von Arx 1986). Vonarxia resembles Fumagopsis (Wu \& Sutton 1995), however, Fumagopsis has star-like conidia, while conidia in Vonarxia have three upper arms that are subcylindrical to cylindrical, and multi-septate. Besides, setae of Vonarxia are septate and have a simple, bulbous base. Based on combined LSU and ITS sequence analysis, $V$. vagans formed a single lineage as a distinct genus in Chaetothyriaceae with 79\% ML BS and 0.9 BY PP support (Fig. 1). 


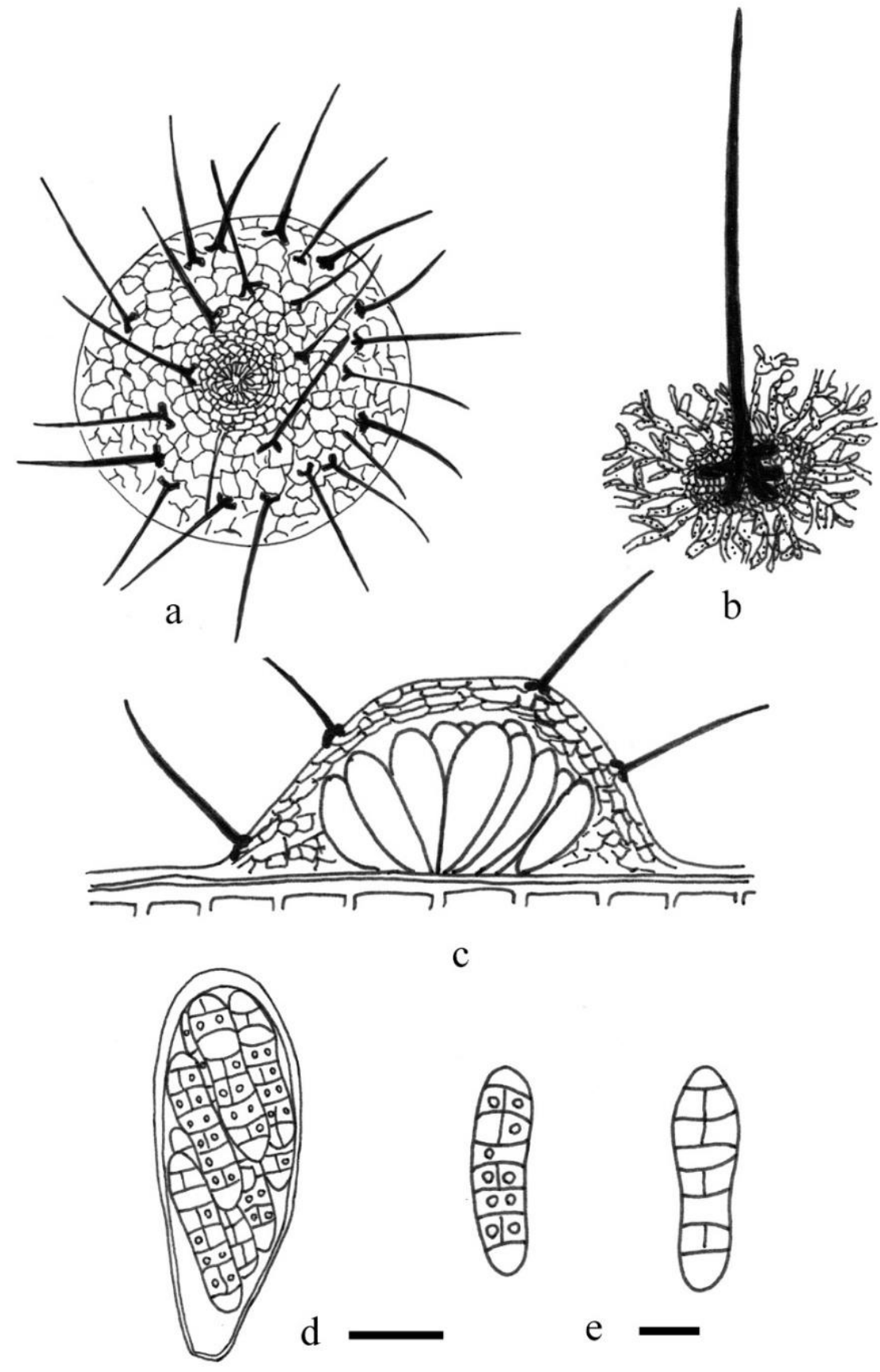

Figure 12 - Treubiomyces pulcherrimus (redrawn from Höhnel 1909, holotype). a Top view of ascoma with setae. b Seta with superficial mycelium on the host. c Vertical section through ascoma wall. d Asci. e Ascospores. Scale bars: $\mathrm{d}=20 \mu \mathrm{m}, \mathrm{e}=10 \mu \mathrm{m}$.

Vonarxia anacardii Bat. \& J.L. Bezerra, in Batista, Bezerra, Maia \& Silva, Publicações Inst. Micol. Recife 283: 7 (1960)

Fig. 13

Index Fungorum number: IF340977; Facesoffungi number: FoF 10345

Description - see Batista et al. (1960), Crous et al. (2009)

Type material - On leaves of Anacardium occidentale L. (Anacardiaceae), Hughes (18881, IMUR, holotype).

Coccodiniaceae Höhn. ex O.E. Erikss., Op. bot. Soc. bot. Lund 60: 42 (1981)

Index Fungorum number: IF80615, Facesoffungi number: FoF 10352, 23 known species

Saprobic, epiphytic or biotrophic on the branches, stems, leaves as sooty moulds and mostly adpressed to the surface of host gaining nutrients from sugary exudates. Subiculum well-developed, 
superficial, loose, comprising effuse, branched, dark brown to blackish brown, septate hyphae. Sexual morph: Ascomata superficial, embedded in subiculum or sometimes sessile on subiculum developing on the surface of the host, solitary to gregarious, globose to subglobose, cupulate when dry, uniloculate, brown to blackish brown, with periphysate ostioles, with or without papillate, covering individual hyphae, with or without setae. Wall of ascoma composed of several layers with outer layers dark brown cells to inner layers hyaline to light brown flattened cells. Hamathecium comprising filiform, hyaline, septate pseudoparaphyses or lacking. Asci 8-spored, bitunicate, fissitunicate, saccate, broadly clavate to oval, sessile or short pedicellate, lacking an ocular chamber, forming in a basal layer of ascoma wall. Ascospores overlapping 1-3-seriate, irregularly arranged, ellipsoid to broadly clavate, fusiform, hyaline to lightly pigmented, yellowish to brownish at maturity, 2-4-trans-septate, or muriform, slightly constricted at the septa, thin-walled, without a gelatinous sheath or appendages, eguttulate. Asexual morph: hyphomycetous (Hughes 1976, Barr 1987, Winka et al. 1998, Crous et al. 2007).

Type-Coccodinium A. Massal.

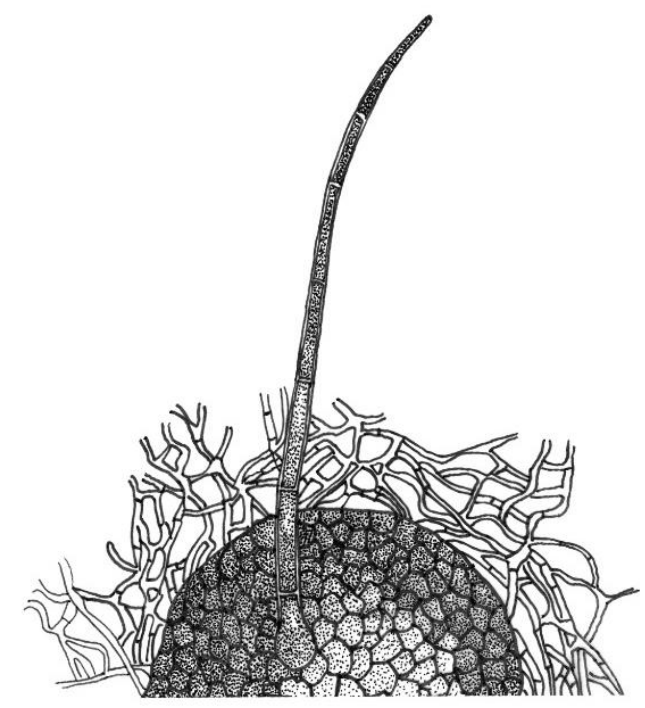

a

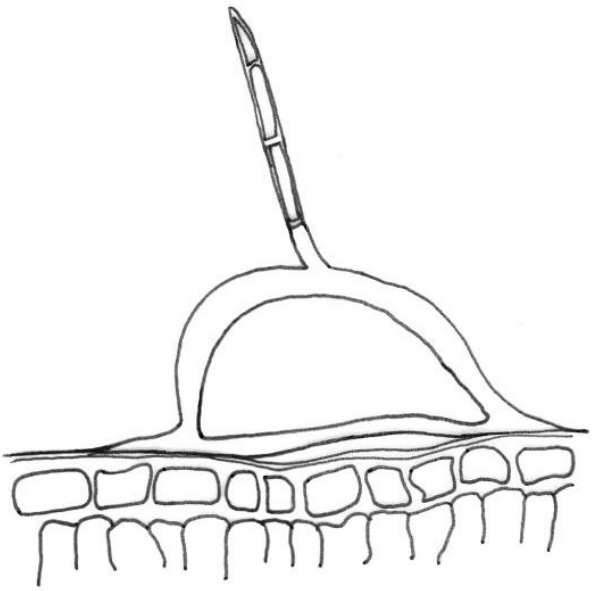

b
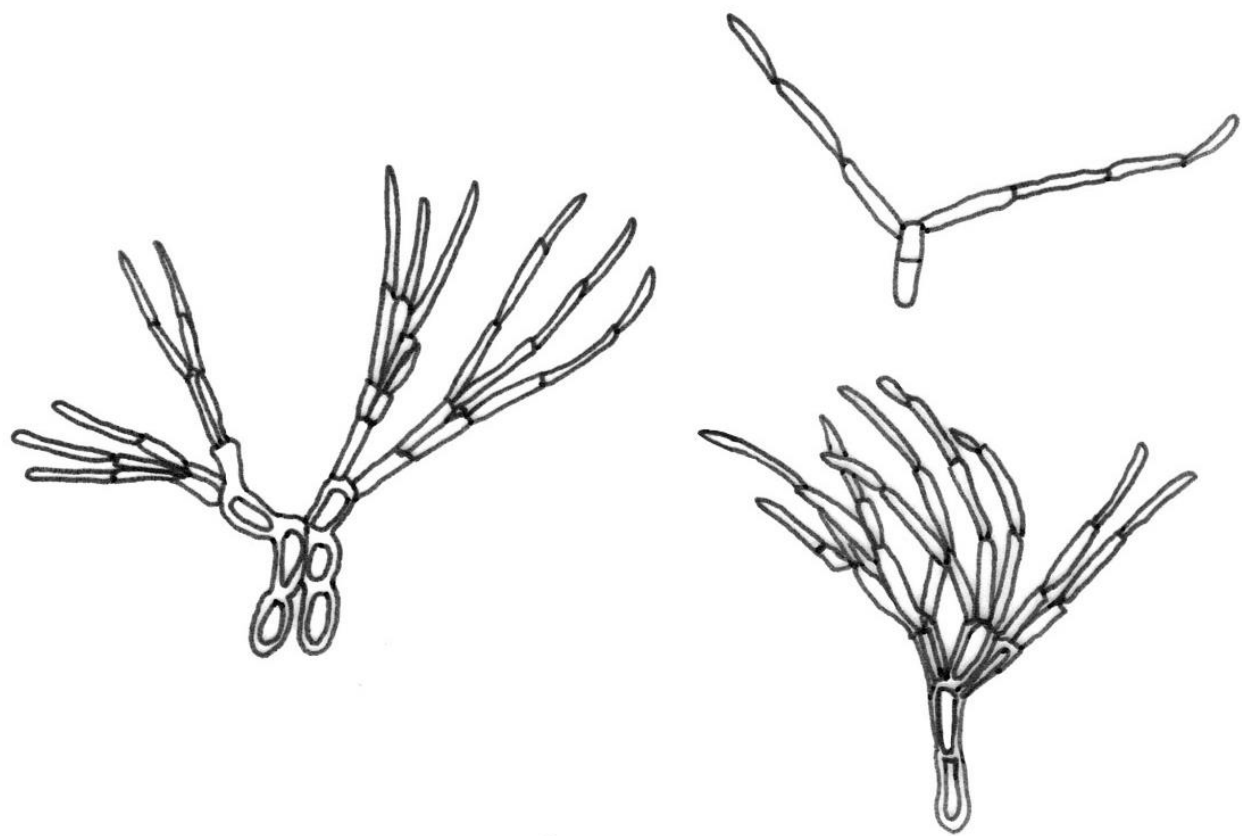

$\mathrm{C}$

Figure 13 - Vonarxia anacardii (18881, IMUR, holotype, Batista et al. 1960). a Conidioma with a seta. $\mathrm{b}$ Vertical section through peridium. $\mathrm{c}$ Conidiogenous cells and filiform conidia. Scale bars: $\mathrm{b}=20 \mu \mathrm{m}$, $\mathrm{c}=10 \mu \mathrm{m}$. 
Notes - The members of Coccodiniaceae are sooty moulds. The species of Coccodiniaceae are adpressed to the surface of leaves, branches, stems, twigs, even whole plants. They obtain nutrients and water from sugary exudates secreted by sap-feeding insects. The family was introduced by Eriksson (1981), comprising Coccodinium A. Massal. (type genus), Dennisiella Bat. \& Cif. and Limacinula Höhn. Kirk et al. (2008) added the asexual genera Bisbyopeltis Bat. \& A.F. Vital and Microxiphium (Harv. ex Berk. \& Desm.) Thüm. to Coccodiniaceae. The family comprises taxa that grow on dark superficial subicula on honeydew on plants (Eriksson 1981), have limacinuloid ascomata (a collabent ascomata on living hosts, producing on a subiculum composed of a very loose arrangement of hyaline hyphae which are individually connected as a component of the lower portion of the fruit body wall, Reynolds 1971), with the hamathecium of pseudoparaphyses. Hughes (1976) found phialidic conidiogenous cells formed in rosettes on the ascospores, and subsequently, Barr (1987) found a Microxiphium asexual state. Microxiphium was placed in Capnodiaceae based on phylogenetic analyses (Schoch et al. 2006, Crous et al. 2007, Hyde et al. 2013, Liu et al. 2017). Microxiphium is polyphyletic and the type species has already been linked to Dennisiella in Coccodiniaceae (Schoch et al. 2006, Crous et al. 2007, Ruibal et al. 2009). Winka et al. (1998) found that the asexual state shares similar characters with Capnodendron species (Antennulariellaceae). Crous et al. (2007) found that colonies of C. bartschii on MEA are slow-growing and produce the asexual state. Hyde et al. (2013) suggested further collections and sequence data are needed to sort out the confusion surrounding these taxa. In our study, we found the asexual morph around the ascomata, characterized by brown hypha with globose cells, phialidic, globoid to oblong, subhyaline to pale brown conidiogenous cells, with 1-3 conidia produced from phialides, and fusoid-ellipsoidal to clavate, 3-5-septate, brown conidia. Liu \& Hall (2004) assigned Coccodiniaceae to Chaetothyriales based on RPB2 protein sequences analysis. Subsequently, Crous et al. (2007) indicated that the type species of Coccodinium, C. bartschii clustered with $100 \%$ bootstrap support in Herpotrichiellaceae (Chaetothyriales). The phylogenetic analysis based on a combined LSU and ITS dataset showed that Coccodiniaceae forms a distinct clade with affinity to Herpotrichiellaceae and is accommodated in Chaetothyriales with 92\% ML BS and 1.00 BY PP support (Fig. 1). Coccodiniaceae is however, poorly studied phylogenetically. Sequence data from Dennisiella and Limacinula are required to resolve the generic relationships.

Coccodinium A. Massal., Atti Inst. Veneto Sci. lett., ed Arti, Sér. 3 5: 336 (1860) [1859-1860]

Index Fungorum number: IF1140, 4 morphological species (Species Fungorum 2021), 1 species with molecular data.

Type species - Coccodinium bartschii A. Massal.

Notes - Coccodinium was introduced by Massalongo (1860) and is typified by C. bartschii A. Massal. This is a sooty mould genus, occurring with other fungal taxa on the surface of plants, obtaining water and nutrition from the honey-dew of sap-feeding insects (Eriksson 1981, Lumbsch \& Huhndorf 2010, Hyde et al. 2013, Chomnunti et al. 2014). This genus is characterized by a dark brown collabent ascomata forming on well-developed subiculum attached to the host surface, periphysate ostioles, filiform, hyaline, septate pseudoparaphyses, bitunicate asci and muriform ascospores (Reynolds 1971, Eriksson 1981, Barr 1987, Hyde et al. 2013). Coccodinium resembles Naetrocymbe and was synonymized under Naetrocymbe in Arthopyreniaceae (Pleosporales, von Höhnel 1918a, b). In both genera, ascomata are superficial and frequently collabent on a well-developed dark subiculum (von Höhnel 1918a, b). Batista \& Ciferri (1957) transferred Coccodinium bartschii to Cucurbitaria, because they considered the moisture or physical conditions caused the dry, collapsed ascomata to become the full sphaerical-globose ascomata, which fit Cucurbitaria rather than Naetrocymbe. Both genera are similar in having muriform ascospores in bitunicate asci, but Naetrocymbe is different from Coccodinium by clustered ascomata on a basal hypostroma beneath the host periderm and cylindrical asci with a uni-seriate arrangement of spores (Hyde et al. 2013). Eriksson (1981) compared the type species of Coccodinium and excluded it from Naetrocymbe, establishing the new family Coccodiniaceae.

The possible asexual morph of Coccodinium is hyphomycetous. Winka et al. (1998) found that the asexual morph resembled a Capnodendron species (Antennulariellaceae). DNA was extracted from 
the culture and herbarium material of Coccodinium bartschii (UME30232). The phylogeny showed that C. bartschii can be accommodated in Dothideales. Crous et al. (2007) obtained the asexual morph from a pure culture of a sexual strain of $C$. bartschii. The parsimony analysis of the LSU region showed $C$. bartschii clustered with $100 \%$ bootstrap support with Herpotrichiellaceae (Chaetothyriales). We reexamined the herbarium specimen (ex herb IMI 370066), but setae were not observed, maybe they had fallen off as a result of long storage. However, we found the asexual morph around the ascomata which is consistent with the description of Crous et al. (2007). In our study, phylogenetic analysis based on the combined LSU and ITS dataset showed C. bartschii (CPC 13861) can be accommodated in Chaetothyriales with $92 \%$ ML BS and 1.00 BY PP support (Fig. 1).

Coccodinium bartschii A. Massal., Atti Inst. Veneto Sci. lett., ed Arti, Sér. 3 5: 336 (1860) [1859-1860]

Index Fungorum number: IF153614; Facesoffungi number: FoF 10353

Fig. 14

Epiphytic or biotrophic on the branches of Quercus macrocarpa as sooty molds and mostly adpressed to the surface of branches gaining nutrients from sugary exudates of sap-feeding insects. Subiculum well-developed, superficial, loose, comprising effuse, branched, blackish brown, septate hyphae. Sexual morph: Ascomata 220-350 $\mu \mathrm{m}$ high $\times 120-300 \mu \mathrm{m}$ diam. $(\overline{\mathrm{x}}=305 \times 245 \mu \mathrm{m}, \mathrm{n}=10)$, superficial, sessile on subiculum developing on the surface of the branch, perithecial, scattered to aggregated, globose to subglobose, circular when mature, cupulate when dry, uniloculate, brown to dark brown, with periphysate ostioles, with or without papillate, thick-walled, setose at times. Wall of ascoma $18-32 \mu \mathrm{m}(\overline{\mathrm{x}}=25 \mu \mathrm{m}, \mathrm{n}=10)$, thicker at the apex and base, multi-layered, externally comprising pigmented, dark brown, thick-walled cells of textura angularis, with inner layer thinner, composed of irregularly-shaped, flattened, lightly pigmented to hyaline, thin-walled cells of textura prismatica. Hamathecium lacking paraphyses, with numerous periphyses near the ostiole. Asci 48-52 $\times$ 13-17 $\mu \mathrm{m}(\overline{\mathrm{x}}=48 \times 15.8 \mu \mathrm{m}, \mathrm{n}=10), 8$-spored, bitunicate, fissitunicate, saccate, broadly clavate, short pedicellate, lacking a distinct ocular chamber. Ascospores $18-27 \times 3-5 \mu \mathrm{m}(\overline{\mathrm{x}}=24 \times 4.2 \mu \mathrm{m}, \mathrm{n}=10)$, overlapping bi-seriate or multi-seriate, irregularly arranged, ellipsoidal or clavate, fusiform, hyaline to brown, muriform, with 2-4 transverse septa, 1-2 longitudinal septa in the middle cells and sometimes 1-2 longitudinal septa at end cells, constricted at the septum, smooth and thick-walled, lacking a gelatinous sheath or appendages. Asexual morph: hyphomycetous. Hypha comprising of brown, globose cells, giving rise to indistinct phialides with 1-3 conidia. Conidiogenous cell 3-8 $\mu \mathrm{m}$ in diam. $(\overline{\mathrm{x}}=6 \mu \mathrm{m}, \mathrm{n}=10)$, phialidic, globoid to oblong, subhyaline to pale brown, smooth-walled. Conidia 15$22 \times 5-9 \mu \mathrm{m}(\overline{\mathrm{x}}=18 \times 6 \mu \mathrm{m}, \mathrm{n}=10)$, fusoid-ellipsoidal to clavate, widest in the upper third of the conidium, apex obtuse, base subtruncate, lightly pigmented to brown, 3-5-septate, constricted at the septa, smooth-walled, guttulate.

Material examined - Canada, Ontario, on a dead fallen branch of Quercus macrocarpa Michx. (Fagaceae), 19 July 1994, S. J. Hughes (ex herb IMI 370066).

\section{Ecological and economic significance of Coccodiniaceae}

Coccodiniaceae is a sooty mould family, lives on the surface of the host gaining water and nutrients from sugary exudates which have largely sugars and smaller amounts of amino acids, proteins, minerals, vitamins and other organic compounds (Auclair 1963). The honeydew drips cover the whole leaves, branches, stems, twigs even the whole plant tissues with a sticky sugary coating. The sooty moulds cover the sugary exudates and produce a thin or thick subiculum composed of dense, dark hyphae (Hughes 1976, Faull et al. 2002, Chomnunti et al. 2014) which block sunlight and reduces photosynthesis, may result in the death of the plant, lower growth rates and thus reduced yields (de Filho \& Paiva 2006, Nelson 2008, Laemmlen 2011, Santos et al. 2013).

\section{Genera included in Coccodiniaceae}

Dennisiella Bat. \& Cif., Beih. Sydowia 3: 37 (1962)

Index Fungorum number: IF1457, Facesoffungi number: FoF 10354, 7 morphological species (Species Fungorum 2021), molecular data unavailable. 
Type species - Dennisiella babingtonii (Berk.) Bat. \& Cif.

Notes - Dennisiella Bat. \& Cif. was established to accommodate the type species D. babingtonii (Berk.) Bat. \& Cif. and D. caucasica (Woron.) Bat. \& Cif., D. setosicola (Woron.) Bat. \& Cif. and D. theae (Sawada) Bat. \& Cif. (Batista \& Ciferri 1962). The genus is characterized by a well-developed, setose subiculum, comprising effuse, branched, septate hyphae, erect, straight, setae with bulbous base, perithecial, globose ascomata with periphysate ostiole, bitunicate, cylindrical to broadly clavate asci and fusoid, hyaline, 2-6 septate ascospores. Dennisiella resembles Coccodinium in characters of limacinuloid ascomata and hamathecium consisting of periphyses, while species of Dennisiella has ascospores only with 2-6 transverse septa, without longitudinal septa and setose hyphae. Microxiphium is polyphyletic which is clustered with Dennisiella in Coccodiniaceae (Schoch et al. 2006, Crous et al. 2007, Ruibal et al. 2009) and Capnodiaceae (Chomnunti et al. 2011, 2014, Hyde et al. 2013, Liu et al. 2017). However, the type species of Microxiphium is presently placed as a synonym of $D$. babingtonii and thus included in the Coccodiniaceae. Herein, we accept Dennisiella in Coccodiniaceae pending epitypification and neotypification.

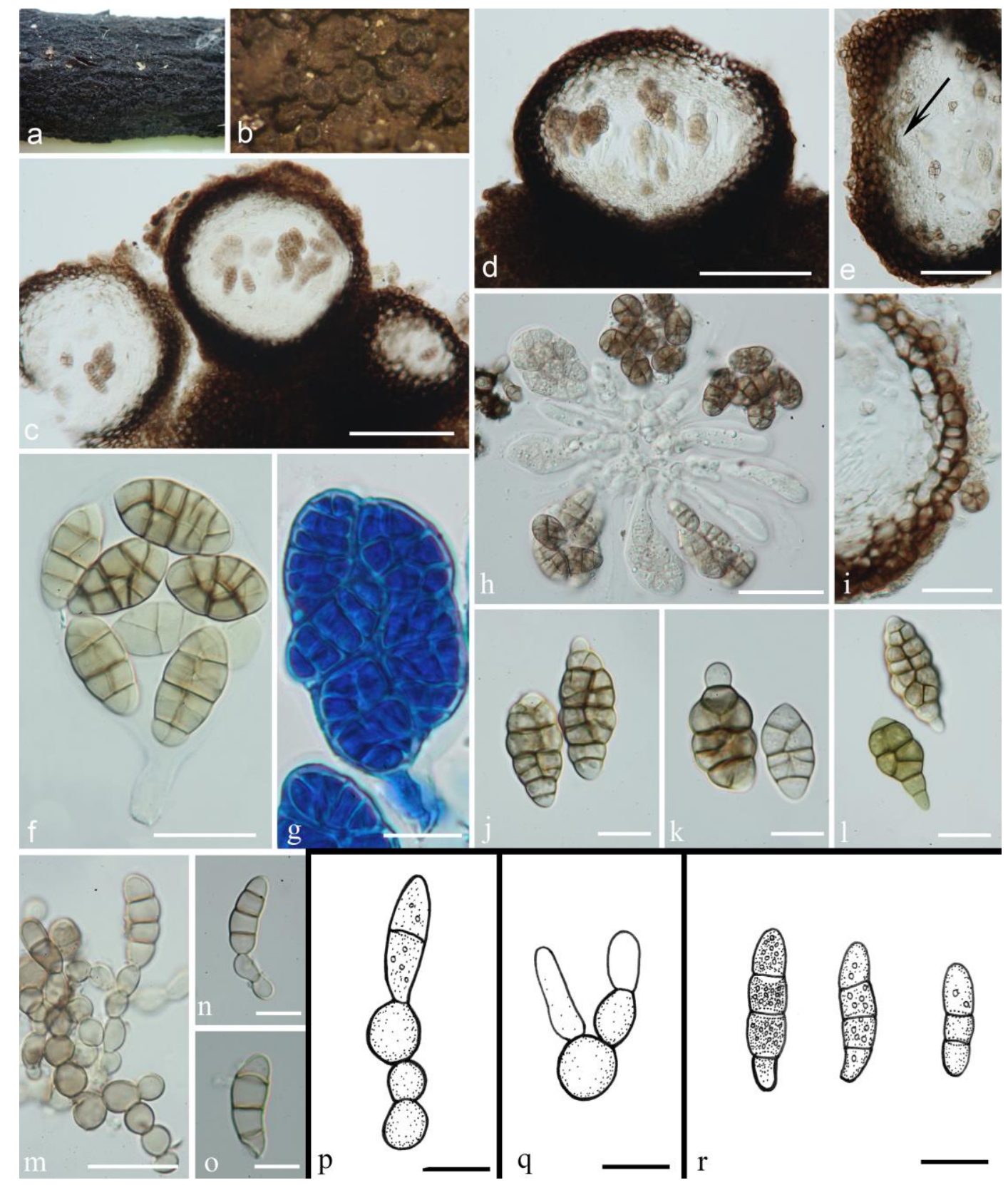

Figure 14 - Coccodinium bartschii (IMI 370066). a Herbarium material. b Appearance of ascomata on the superficial of the branch of Quercus macrocarpa. c, d Vertical sections of ascomata. e Vertical 
section through ostiole (point by an arrow). $\mathrm{f}-\mathrm{h}$ Asci with ascospores. i Vertical section through ascoma wall. $\mathrm{j}-1$ Ascospores. $\mathrm{m}, \mathrm{n}$ Conidiogenous cell giving rise to conidia. o Conidium. $\mathrm{p}-\mathrm{r}$ Redrawn from Crous et al. (2007); $p$, q show conidiogenous cell with conidia, $r$ shows conidia. Scale bars: $c, d=100$ $\mu \mathrm{m}, \mathrm{e}, \mathrm{h}, \mathrm{i}=50 \mu \mathrm{m}, \mathrm{f}, \mathrm{m}=20 \mu \mathrm{m}, \mathrm{g}, \mathrm{j}-\mathrm{l}, \mathrm{n}-\mathrm{r}=10 \mu \mathrm{m}$.

Dennisiella babingtonii (Berk.) Bat. \& Cif., Beih. Sydowia 3: 38 (1962)

Fig. 15

三Strigula babingtonii Berk., Suppl. Engl. Bot. 4: tab. 2957 (1849)

For other synonyms see Index Fungorum

Index Fungorum number: IF329804; Facesoffungi number: FoF 10355

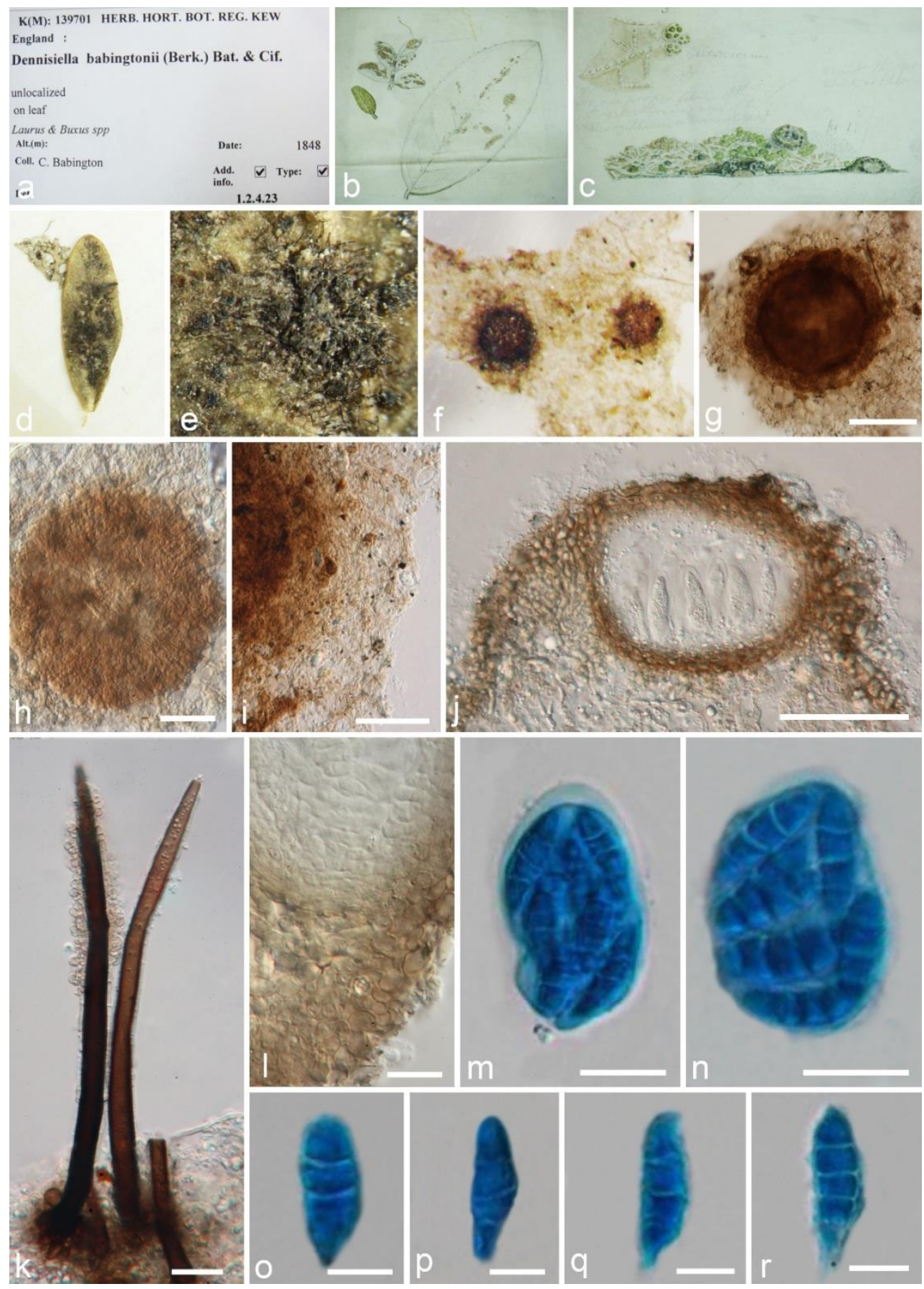

Figure 15 - Dennisiella babingtonii (K(M) 139701, holotype of Strigula babingtonii). a Envelop and collection information of Dennisiella babingtonii. b, c Drawing of ascomata on the host leaves. $\mathrm{d}$ Herbarium material. e Appearance of ascomata with setae on the superficial of the host. $\mathrm{f}-\mathrm{i}$ Squash mount of ascomata. $\mathrm{j}$ Vertical section of ascoma. $\mathrm{k}$ Setae. 1 Vertical section through ascoma wall. 
$\mathrm{m}, \mathrm{n}$ Asci with ascospores, stained in lactophenol cotton blue. o-r Ascospores, stained in lactophenol cotton blue. Scale bars: $\mathrm{g}-\mathrm{j}=50 \mu \mathrm{m}, 1, \mathrm{k}=20 \mu \mathrm{m}, \mathrm{m}, \mathrm{n}=10 \mu \mathrm{m}, \mathrm{o}-\mathrm{r}=5 \mu \mathrm{m}$.

Epiphytic or biotrophic on the leaves of Laurus spp. and Buxus spp. as sooty molds adpressed to the surface of host gaining nutrients from sugary exudates of sap-feeding insects. Subiculum welldeveloped, superficial, pelliculose, loose, blackish or grayish, comprising effuse, branched, subhyaline to olivaceous, 2-3 $\mu \mathrm{m}$, septate hyphae, setose, reticulate. Setae erect, straight, tapering to the apex, bulbose at the base (Batista \& Ciferri 1962). Sexual morph: Ascomata $85-250 \mu \mathrm{m}$ in diam. $(\overline{\mathrm{x}}=187$ $\mu \mathrm{m}, \mathrm{n}=10$ ), superficial, sessile on subiculum, perithecial, scattered to aggregated, globose, circular when dry, uniloculate, brown to black, with periphysate ostiole, thick-walled, glabrous. Wall of ascoma 32-56 $\mu \mathrm{m}(\overline{\mathrm{x}}=43 \mu \mathrm{m}, \mathrm{n}=10)$, multi-layered, externally comprising pigmented, dark brown, thickwalled cells of textura angularis, with inner layer thinner, composed of irregularly-shaped, flattened, lightly brown to hyaline, thin-walled cells of textura prismatica. Hamathecium lacking paraphyses. Asci 48-65 $\times 13-17 \mu \mathrm{m}(\overline{\mathrm{x}}=55 \times 16.2 \mu \mathrm{m}, \mathrm{n}=10), 8$-spored, bitunicate, fissitunicate, cylindrical to broadly clavate, short pedicellate or sessile, lacking a distinct ocular chamber. Ascospores $15-25 \times 4-8 \mu \mathrm{m}(\overline{\mathrm{x}}=$ $21 \times 6.8 \mu \mathrm{m}, \mathrm{n}=10$ ), overlapping bi-seriate or multi-seriate, irregularly arranged, fusoid, hyaline, $2-6$ septate, slightly constricted at the septum, smooth and thick-walled, lacking a gelatinous sheath or appendages. Asexual morph: Undetermined.

Material examined - UK, unlocalized, on leaves of Laurus (Lauraceae) and Buxus spp. (Buxaceae), 1848, C. Babington (K(M) 139701, holotype of Strigula babingtonii).

Limacinula Höhn., Sber. Akad. Wiss. Wien, Math.-naturw. Kl., Abt. 1 116: 101 (1907)

Index Fungorum number: IF2869, Facesoffungi number: FoF 10356, 12 morphological species (Species Fungorum 2021), molecular data unavailable.

Type species - Limacinula samoensis Höhn. [as 'samoënsis']

Notes - Reynolds (1971) introduced Limacinula to accommodate six species, viz., L. anomala, L. butleri, L. javanica, L. musicola, L. samoensis and L. theae. The genus is characterized by a welldeveloped, superficial subiculum composed of effuse, branched hyphae, perithecial, setose ascomata with periphysate ostiole, aparaphyses, bitunicate, clavate, obpyriform to obovoid asci and fusoid to oblong, hyaline to light brown, muriform ascospores. Limacinula and Phaeosaccardinula, have been merged in earlier studies by von Höhnel $(1909,1910)$. Reynolds (1971) distinguished Limacinula from Phaeosaccardinula as indicated by differences in ascomata anatomy, ascospore pigmentation and presence of hamathecium. Species of Limacinula are similar to Coccodinium, as both genera have limacinuloid ascomata and a hamathecium lacking paraphyses, however, the former genus has hyaline to pale brown ascospores, while in the latter the ascospores are dark brown. Considering the morphological similarities, we retain Limacinula in Coccodiniaceae, however, fresh collections and sequence data are needed to clarify the familial placement.

Limacinula samoensis Höhn. [as 'samoënsis'], Sber. Akad. Wiss. Wien, Math. -naturw. Kl., Abt. 1 118: 1200 (1909)

Index Fungorum number: IF627637, Facesoffungi number: FoF 10357

Fig. 16

Saprobic, Epiphytic or biotrophic on the leaves of Ficus elastica, mixed with other fungal taxa, as sooty molds adpressed to the surface of host gaining nutrients from sugary exudates of sap-feeding insects. Subiculum well-developed, superficial, loose, brown, comprising effuse, branched, subhyaline to brown, septate hyphae, reticulate. Sexual morph: Ascomata $135-220 \mu \mathrm{m}$ in diam. $(\overline{\mathrm{x}}=155 \mu \mathrm{m}, \mathrm{n}=$ 10), superficial, sessile on subiculum, perithecial, scattered to aggregate, globose, collabent when mature, uniloculate, brown to black, with periphysate ostiole, thick-walled, more or less setose. Wall of ascoma $32-48 \mu \mathrm{m}(\overline{\mathrm{x}}=40 \mu \mathrm{m}, \mathrm{n}=10)$, multi-layered, externally comprising pigmented, dark brown, thick-walled cells of textura angularis, with inner layer thinner, composed of irregularly-shaped, flattened, lightly brown to hyaline, thin-walled cells of textura angularis. Hamathecium lacking paraphyses. Asci 58-115 × 22-52 $\mu \mathrm{m}(\overline{\mathrm{x}}=87 \times 38 \mu \mathrm{m}, \mathrm{n}=10), 8$-spored, bitunicate, fissitunicate, clavate when immature, obpyriform to obovoid at maturity, short pedicellate or sessile, lacking a 
distinct ocular chamber. Ascospores $22-35 \times 8-12 \mu \mathrm{m}(\overline{\mathrm{x}}=30 \times 9.5 \mu \mathrm{m}, \mathrm{n}=10)$, overlapping uniseriate to multi-seriate, irregularly arranged, fusoid to oblong, basal cells thinner than upper cells, rounded at both ends, hyaline to light brown, muriform, with 6-8 transverse septa, 3-6 longitudinal septa, constricted at the septum, slightly constricted at the septum, smooth and thick-walled, lacking a gelatinous sheath or appendages. Asexual morph: Undetermined.

Material examined - Indonesia, Java, on leaves of Ficus elastica Roxb. ex Hornem. (Moraceae), 1908, von Höhnel (K, Ex Herbarium von Höhnel).
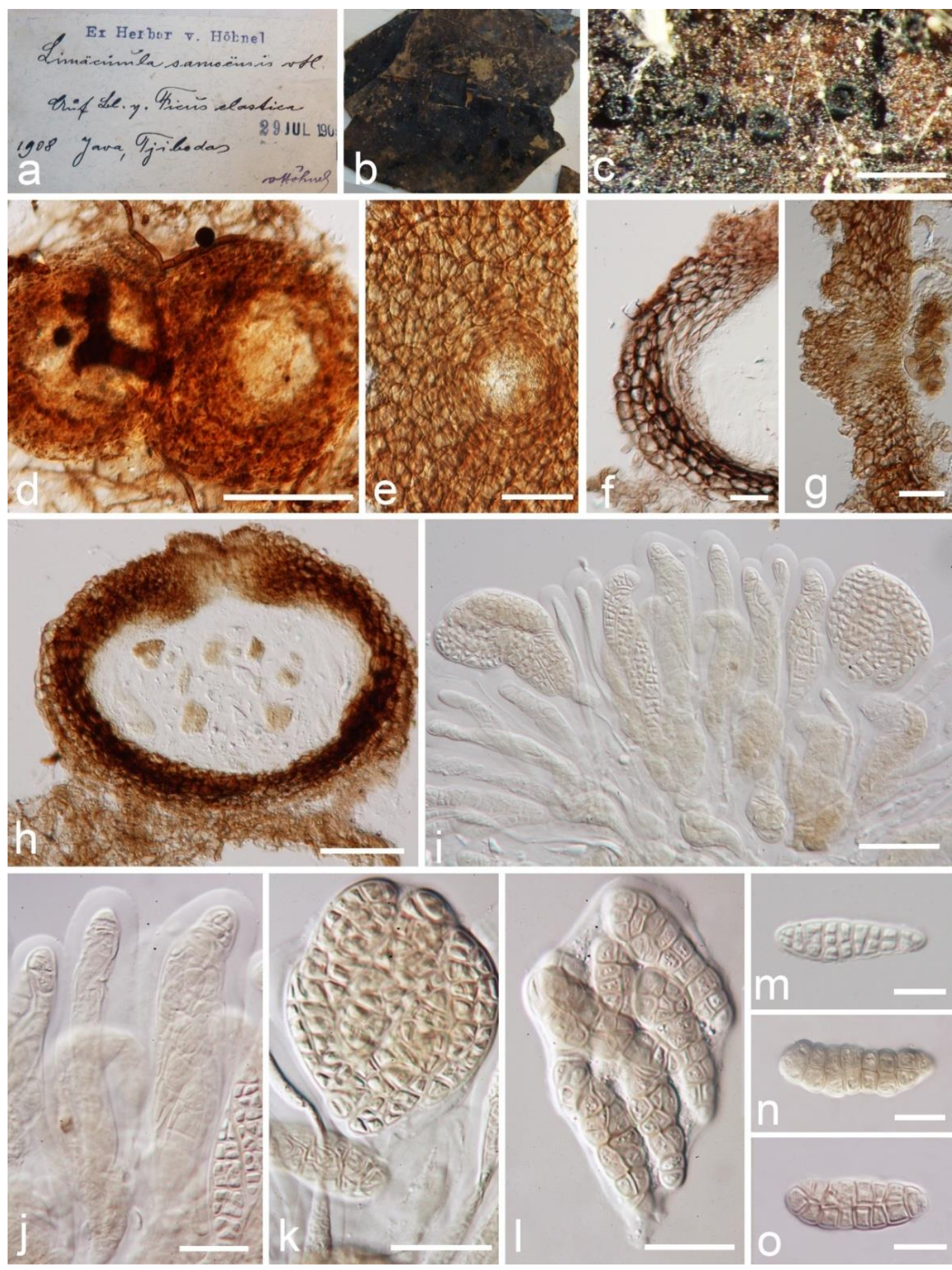

Figure 16 - Limacinula samoensis (K, Ex Herbarium von Höhnel). a Envelop and collection information of Limacinula samoensis. b Herbarium material. c Appearance of ascomata on the superficial of the host. d, e Squash mounts of ascoma. f Vertical section through ascoma wall. g Vertical section through ostiole. $\mathrm{h}$ Vertical section of ascoma. i-l Asci with ascospores. $\mathrm{m}-\mathrm{o}$ Ascospores. Scale bars: $\mathrm{c}=500 \mu \mathrm{m}, \mathrm{d}=100 \mu \mathrm{m}, \mathrm{e}, \mathrm{h}=50 \mu \mathrm{m}, \mathrm{f}, \mathrm{g}, \mathrm{i}=25 \mu \mathrm{m}, \mathrm{j}-\mathrm{l}=20 \mu \mathrm{m}, \mathrm{m}-\mathrm{o}=10 \mu \mathrm{m}$. 
Cyphellophoraceae Réblová \& Unter., PLoS ONE 8(5): e63547, 10 (2013)

Index Fungorum number: IF803682, Facesoffungi number: FoF 10358, 26 known species.

Epiphytic, saprobic or pathogenic on a range of hosts worldwide. Colonies mostly growing slowly, pale grey-brown in the center, cream-colored, light mouse grey to dark grey, loose, cottony, woolly-velvety, margin entire, flat, straight or sharp, dark brown to olivaceous black, reverse olivaceous black, somewhat moist. Vegetative hyphae hyaline initially, pale brown or grey olivaceous when mature, septate, constrictions at the septa, straight or undulate, smooth-walled, guttulate or aguttulate, with or without oil droplets. Sexual morph: Ascomata scattered, subglobose to globose, dark brown, glabrous, thick-walled, ostiolate or ostiole inconspicuous, with or without dark superficial hyphae. Wall of ascoma multi-layered, comprising brown to hyaline cells of textura angularis and textura globulosa. Asci 8-spored, bitunicate, ellipsoidal to cylindrical, ovoid to ampulliform, with a short pedicel. Ascospores 2-3-seriate, ellipsoidal to fusiform, hyaline, 1-3-septate, not constricted at the septa, narrowly round at the ends, with or without a guttule in each cell (Yang et al. 2018, Phookamsak et al. 2019). Asexual morph: hyphomycetous. Conidiophores absent or rarely reduced to a short cell basal to the conidiogenous cells. Conidiogenous cells enteroblastic, phialidic, short cylindrical to flask-shaped, ampulliform, intercalary, lateral or terminal, sometimes arising at short side branches of hyphae, with indistinct sessile collarettes or short and flaring to funnel-shaped collarettes, sub-hyaline to pale olivaceous brown, producing subsequent conidia in more or less sympodial order, thin-walled. Conidia aggregated, oblong-fusoid or oblong-ovoid or triangular, 1-multi-septate or aseptate, constrictioned at the septa, hyaline to brown, straight or sometimes concave, smooth-walled, guttulate or aguttulate, with or without oil droplets, without a gelatinous sheath or appendages. Spermatial state absent. Chlamydospores absent.

Type - Cyphellophora G.A. de Vries

Notes - Réblova et al. (2013) introduced Cyphellophoraceae Réblová \& Unter. to accommodate the type genus Cyphellophora G.A. de Vries with eight species from Cyphellophora and six species from Phialophora Medlar based on morphology, secondary structure data and phylogenetic analysis which formed a distinct lineage within Chaetothyriales. Anthopsis was formally established in Cyphellophoraceae by Moussa et al. (2016). Thus, the definition of Cyphellophoraceae was extended to include flask-shaped or ampulliform phialides or phialide-like cells with indistinct sessile collarettes or short and flaring to funnel-shaped collarettes, and oblong-fusoid to oblong-ovoid or triangular conidia with or without septa. Currently, two sexual morph species are accepted, viz. Cyphellophora jingdongensis H. Yang \& K.D. Hyde and C. filici Hongsanan et al. isolated from plant material (Yang et al. 2018, Phookamsak et al. 2019).

Cyphellophora G.A. de Vries, Mycopath. Mycol. appl. 16(1): 47 (1962)

Index Fungorum number: IF7885, Facesoffungi number: FoF 10359, 26 morphological species (Species Fungorum 2021), 22 species with molecular data.

Epiphytic, saprobic and pathogenic on a range of hosts worldwide. Colonies mostly growing slowly, pale grey-brown in the center, loose, cottony, woolly-velvety, margin entire, flat, straight or sharp, dark brown to olivaceous black, reverse olivaceous black, somewhat moist. Vegetative hyphae hyaline initially, pale brown in older hyphae, septate, constrictions at the septa, straight or undulate, smooth-walled, guttulate or aguttulate, with or without oil droplets. Sexual morph: Ascomata scattered, subglobose to globose, dark brown, glabrous, thick-walled, ostiolate or ostiole inconspicuous, with or without dark superficial hyphae. Wall of ascoma multi-layered, comprising brown to hyaline cells of textura angularis and textura globulosa. Asci 8-spored, bitunicate, ellipsoidal to cylindrical, ovoid to ampulliform, with a short pedicel. Ascospores 2-3-seriate, ellipsoidal to fusiform, hyaline, 1-3 septate, not constricted at the septa, narrowly rounded at the ends, with or without a guttule in each cell (Yang et al. 2018, Phookamsak et al. 2019). Asexual morph: Hyphomyctous. Conidiophores absent or rarely reduced to a short cell, basal to the conidiogenous cells. Conidiogenous cells enteroblastic, phialidic. short cylindrical to flask-shaped, intercalary, lateral or terminal, sometimes arising at short side branches of hyphae, with indistinct sessile collarettes or short and flaring to funnel-shaped collarettes, sub-hyaline to pale olivaceous brown, producing subsequent conidia in more or less sympodial order, 
thin-walled. Conidia aggregated, oblong-fusoid or oblong-ovoid, 1-multi-septate, constrictioned at the septa, hyaline to brown, straight or curved, smooth-walled, guttulate or aguttulate, with or without oil droplets, without a gelatinous sheath or appendages. Spermatial state absent. Chlamydospores absent (de Vries 1962, Feng et al. 2014).

Type species - Cyphellophora laciniata G.A. de Vries

Notes - Cyphellophora G.A. de Vries is widespread and is ecologically important. Species of Cyphellophora comprise; (1) mostly human and animal pathogens, such as $C$. laciniata G.A. de Vries (type species), C. europaea (de Hoog, Mayser \& Haase) Réblová \& Unter. and C. pluriseptata G.A. de Vries which were isolated from nails or skin of humans (de Vries 1962, de Hoog et al. 2000a, Feng et al. 2012, 2014), C. phyllostachysdis G.Y. Sun \& Liu Gao, C. europaea, from a human or mammal eyes, resulting in infection of hyperkeratosis (de Hoog et al. 2000a); (2) saprobes, such as $C$. filici isolated from dead fronds of a fern, without superficial dark hyphae (Phookamsak et al. 2019), C. oxyspora (W. Gams) Réblová \& Unter. isolated from a decaying leaf of Clerodendron monahassa (Vu et al. 2019); (3) epiphytes, such as $C$. jingdongensis which can reduce photosynthesis, but does not cause plant disease (Chomnunti et al. 2014, Yang et al. 2018), and (4) plant pathogens, such as C. phyllostachysdis G.Y. Sun \& Liu Gao and C. sessilis (de Hoog) Réblová \& Unter. causing sooty blotch and flyspeck disease of bamboo, resulting in economic damage (de Hoog et al. 2000, Decock et al. 2003, Zhuang et al. 2010, Gleason et al. 2011, Gao et al. 2015).

To date, 26 species are accepted in Cyphellophora, with two sexual morph species, C. jingdongensis isolated from living leaves of Alnus nepalensis (Yang et al. 2018) and C. filici isolated on dead fronds of a fern (Phookamsak et al. 2019). There are nine species reported from plant material, namely as $C$. artocarpi G.Y. Sun \& Liu Gao, C. filici, C. guyanensis Decock \& G. Delgado, $C$. jingdongensis, C. musae, C. olivacea (W. Gams) Réblová \& Unter., C. oxyspora, C. phyllostachydis and C. sessilis (Gams \& Holubová-Jechová 1976, de Hoog et al. 1999, Decock et al. 2003, Gao et al. 2015, Yang et al. 2018, Phookamsak et al. 2019).

The asexual morphs of Cyphellophora are recognized as black yeasts which are difficult to identify solely based on morphology. Cyphellophora resembles black yeasts, such as Phialophora Medlar and Pseudomicrodochium B. Sutton, but they differ from each other in having different conidia and thallus colours (Decock et al. 2003, de Hoog et al. 2011, Réblová et al. 2013). Thus, a combination of morphology, ecological traits and phylogenetic analyses provide accurate generic and species delimitation in Cyphellophora. Phylogenetic studies have shown that Cyphellophora clustered in a well-supported clade within Chaetothyriales (Feng et al. 2014, Gao et al. 2015, Yang et al. 2018, Phookamsak et al. 2019).

Cyphellophora laciniata G.A. de Vries, Mycopath. Mycol. appl. 16(1): 47 (1962)

Fig. 17

Index Fungorum number: IF329520; Facesoffungi number: FoF 10360

Pathogenic on skin scales of a human patient. Colonies woolly-velvety, grey, margin entire, reverse olivaceous black to black. Vegetative hyphae 2-3 $\mu \mathrm{m}$ wide, hyaline initially, pale brown in older hyphae, septate, constrictions at the septa, straight or undulate, smooth-walled, with inflated cells, sometimes with dark brown excrescences in older hyphae, guttulate when young, the older hyphae with many oil droplets. Sexual morph: Undetermined. Asexual morph: hyphomycetous. Conidiophores absent or rarely reduced to a short cell basal to the conidiogenous cells. Conidiogenous cells enteroblastic, phialidic, short cylindrical to flask-shaped, intercalary, lateral or terminal, sometimes arising at short side branches of hyphae, with a short flaring collarette, sub-hyaline to pale olivaceous brown, thin-walled. Conidia 11-25 × 2-5 $\mu \mathrm{m}$, oblong-fusoid or oblong-ovoid, 1-3-transverse-septate, constrictioned at the septa, hyaline to brown, straight or curved, smooth-walled, guttulate when young, with many oil droplets in the older hyphae, without a gelatinous sheath or appendages. Spermatial state is absent. Chlamydospores absent (Description modified according to de Vries 1962, Feng et al. 2014).

Type material - Switzerland, Basel, probably as a contaminant, from skin scales of a human patient, 1954, Wissel K.M. (Centraalbureau voor Schimmelcultures, holotype). 


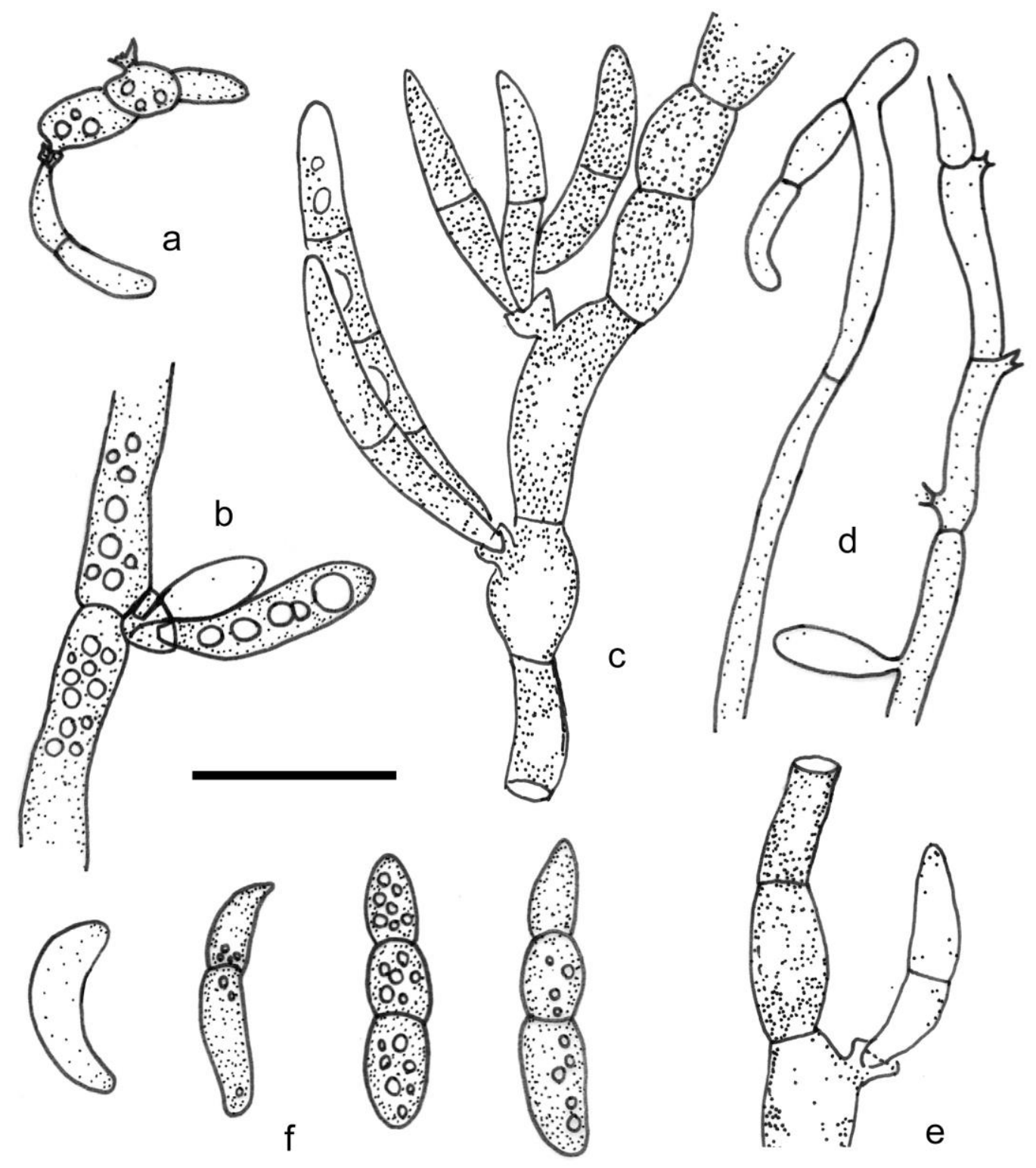

Figure 17 - Cyphellophora laciniata (Centraalbureau voor Schimmelcultures, holotype, redrawn from de Vries 1962). a-e Conidiogenous cells with conidia. f Conidia. Scale bar: $20 \mu \mathrm{m}$.

\section{Ecological and economic significance of Cyphellophoraceae}

Species of Cyphellophoraceae are cosmopolitan and comprise saprobes, epiphytes and plant and animal (including humans) pathogens from a variety of habitats. Anthopsis deltoidei, Cyphellophora laciniata, C. europaea, C. oxyspora, C. pauciseptata, C. pluriseptata, C. phyllostachysdis, C. reptans, C. suttonii, $C$. vermispora, $C$. suttonii and $C$. fusarioides have been reported from animals including human clinical samples causing infection or human phaeohyphomycosis (de Vries 1962, Ajello et al. 1980, Sutton et al. 1991, Perfect \& Schell 1996, de Hoog et al. 1999, 2000, Feng et al. 2012). Anthopsis catenata, A. deltoidei, A. microspora, Cyphellophora europaea, C. reptans, C. laciniata and C. suttonii have been reported from nonclinical sources from environmental samples in humid environments (i.e., foam of a river, soil samples, bathrooms, washing machines and food) (Marchisio et al. 1977, Gams \& Holubová-Jechová 1976, Sutton et al. 1991, Lopez et al. 2007, Li et al. 2011). Cyphellophora filici and C. oxyspora was found on dead fronds and decaying leaves respectively (Phookamsak et al. 2019, Vu et al. 2019). Cyphellophora jingdongensis is a sooty mould species that reduce photosynthesis rates in the host (Yang et al. 2018). Cyphellophora phyllostachysdis and C. sessilis are plant pathogens that cause 
sooty blotch and flyspeck (Gao et al. 2015). Therefore, most species of Cyphellophoraceae have ecological and economic significance being harmful to the animals (including humans) and plants or beneficial.

\section{Genera included in Cyphellophoraceae}

Anthopsis Fil. March., A. Fontana \& Luppi Mosca, Can. J. Bot. 55(2): 117 (1977)

Index Fungorum number: IF7173, Facesoffungi number: FoF 10361, 3 morphological species (Species Fungorum 2021), 2 species with molecular data.

Type species - Anthopsis deltoidea Fil. March., A. Fontana \& Luppi Mosca

Saprobic on soil, foam of a river, or pathogenic on human subcutaneous infection. Colonies cream-colored, light mouse grey to dark grey, velvety-woolly. Hyphae grey olivaceous when mature, septate, constrictions at the septa, smooth-walled, guttulate or aguttulate, with or without oil droplets. Sexual morph: Undetermined. Asexual morph: hyphomycetous. Conidiophores absent or rarely reduced to a short cell basal to the conidiogenous cells. Conidiogenous cells enteroblastic, inverted, phialidic, clustering as two to eight ampulliform phialides, arising from a hyphal swelling, with distinct sessile collarettes at the base, near the point where the phialide is inserted on the hypha, forming disk flowers of a capitulum, sometimes integrated, with a sessile collarette, sub-hyaline to pale olivaceous. Conidia aggregated, but easily dispersed, ellipsoidal or pyriform, mature conidia deltoid, sometimes ellipsoidal to subspherical in chains, aseptate, hyaline to pale brown, grey olivaceous, straight at one side or sometimes concave, smooth-walled, aguttulate, without oil droplets, without a gelatinous sheath or appendages. Spermatial state absent. Chlamydospores absent (Rayner 1970, Moussa et al. 2016)

Notes - Marchisio et al. (1977) introduced Anthopsis Fil. March. et al. to accommodate Anthopsis deltoidei Fil. March. et al. which was isolated from soil in Italy. Subsequently, A. catenata Oorschot et al. and A. microspora K. Ando \& Tubaki were added, but represented by only one or two strains with a brief description (van Oorschot et al. 1982, Ando \& Tubaki 1985, Moussa et al. 2016). Anthopsis is reported from Germany, Italy, and Japan and are isolated from soil and foam in stream (A. catenata, A. deltoidei and A. microspora) and a human pathogen causing phaeohyphomycosis (A. deltoidei) (Marchisio et al. 1977, van Oorschot et al. 1982, Ando \& Tubaki 1985). Species are dematiaceous hyphomycetes with melanized filamentous thalli, inverted, ampulliform phialides with conidiogenous loci, flower-shaped phialides and collarettes and triangular conidia, sometimes in chains. The conidiogenous cells resemble Phialophora Medlar, but Anthopsis has unique triangular conidia. The type species A. deltoidei clustered with Cyphellophora G.A. de Vries in phylogenetic analysis and was transferred to Cyphellophoraceae (Moussa et al. 2016, this study, Fig. 1). However, The LSU sequence of Anthopsis catenata (CBS 492.81) is shown that is not related to any species of Cyphellophoraceae (Moussa et al. 2016 and this study). Thus, our tree does not include the unrelated sequence and the placement of Anthopsis in Cyphellophoraceae is confirmed based on the asexual morph species, Anthopsis deltoidei and A. microspora.

Anthopsis deltoidea Fil. March., A. Fontana \& Luppi Mosca, Can. J. Bot. 55(2): 117 (1977)

Fig. 18

Index Fungorum number: IF308727; Facesoffungi number: FoF 10362

Description: see Marchis et al. (1977)

Type material - Italy, Botanical Garden of the University of Turin, isolated from a horticultural soil, June 1974, Ceruti and Luppi Mosca (CMT 11 11.74, holotype).

Epibryaceae S. Stenroos \& Gueidan, Mycol. Progr. 13(4): 1037 (2014)

Index Fungorum number: IF808432; Facesoffungi number: FoF 10363

Saprobic on or between hairy leaves or leaf lamellae of hosts. Sexual morph: Ascomata perithecioid, superficial, solitary, subglobose to globose, ovoid or pyriform, light to dark brown to black, ostioles without periphyses, apapillate, setose. Setae simple, arising at the upper part, usually, apex rounded, occasionally tapering towards the apex, dark brown, straight or curved, septate, slightly 
constricted at the septa. Wall of ascoma multi-layered, comprising brown to dark brown cells of textura angularis, apex cells darker and thicker walls, lacking interascal tissue cells. Hamathecium lacking paraphyses. Asci 8-spored, bitunicate, oblong to ovoid, ellipsoid, to nearly subcylindrical, without a pedicel, apex rounded, with or without apical structures, sometimes hymenial jelly reddish in Lugol's solution, embedded in a gelatinous matrix. Ascospores overlapping 2-3-seriate, ellipsoid to fusiform, sub-clavate, tapering towards both ends, hyaline or pale grey to lightly brown, 0 to trans-septate, not constricted or slightly constricted at the septa, thin-walled, with or without gelatinous sheath, guttulate. Asexual morph: Undetermined.

Type - Epibryon Döbbeler

Notes - Gueidan et al. (2014) established Epibryaceae to accommodate most Epibryon species, including the type species E. plagiochilae, and Leptomeliola ptilidii, Cladophialophora minutissima and some rock-inhabiting taxa. The key characters of Epibryaceae are globose to subglobose, setose ascomata and oblong to fusiform to sub-clavate ascospores. The family contains a single genus Epibryon with sexual morphs and asexual collections are from rocks and vascular plants (Gueidan et al. 2014).

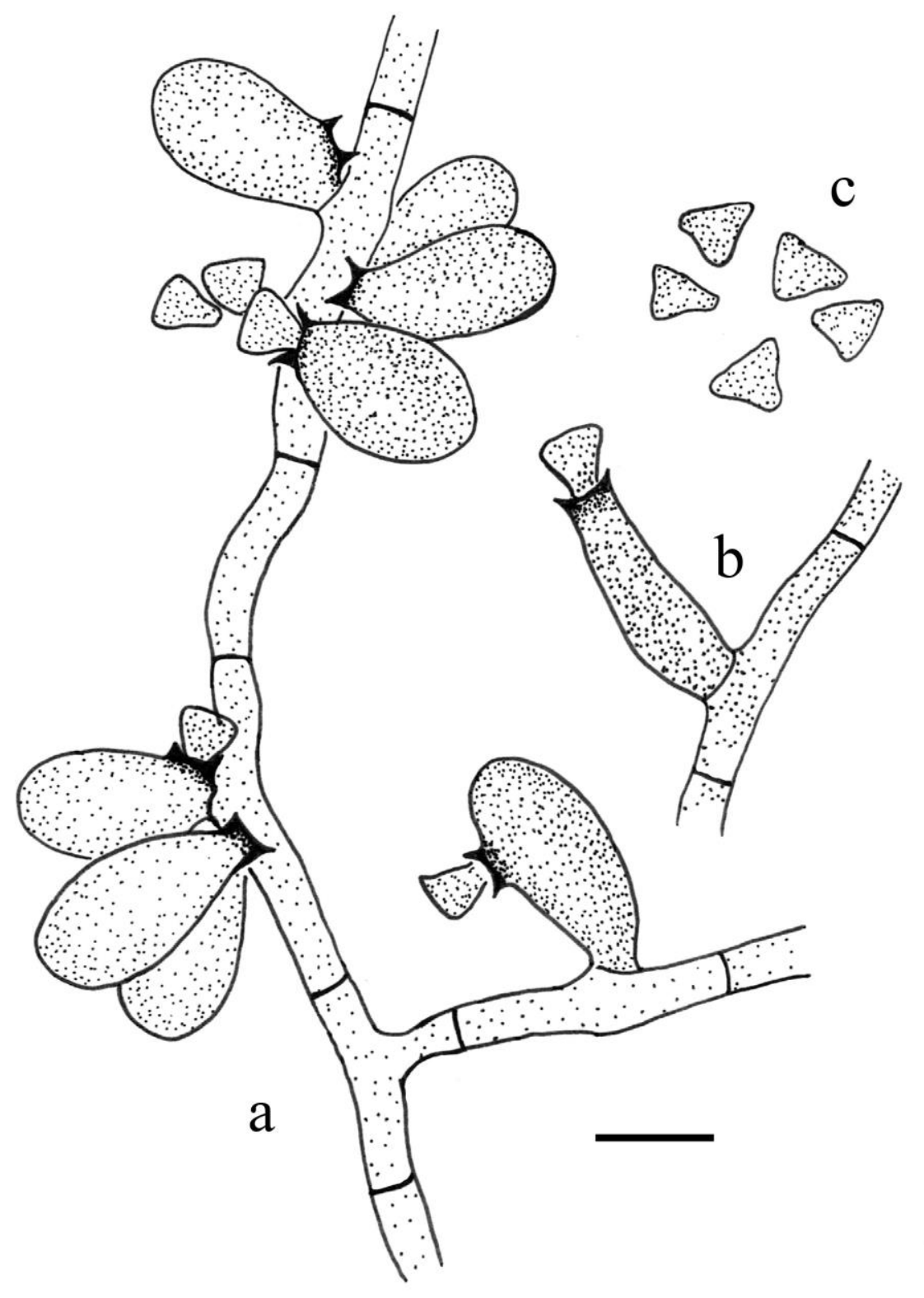

Figure 18 - Anthopsis deltoidea (redrawn from Seifert et al. 2011). a, b Conidiogenous cells have a typical basal collarette. c Conidia. Scale bar: $5 \mu \mathrm{m}$. 
Epibryon Döbbeler, Mitt. bot. StSamml., Münch. 14: 260 (1978)

Index Fungorum number: IF1855, Facesoffungi number: FoF 10366, 46 morphological species (Species Fungorum 2021), 7 species with molecular data.

Saprobic on or between hairy leaves or leaf lamellae of hosts. Sexual morph: Ascomata perithecioid, superficial, solitary, subglobose to globose, ovoid or pyriform, light to dark brown to black, ostioles without periphyses, apapillate, setose. Setae simple, arising at the upper part, usually, apex rounded, occasionally tapering towards the apex, dark brown, straight or curved, septate, slightly constricted at the septa. Wall of ascoma multi-layered, comprising brown to dark brown cells of textura angularis, apical cells darker and thicker walls, lacking interascal tissue cells. Hamathecium lacking paraphyses. Asci 8-spored, bitunicate, oblong to ovoid, ellipsoid, to nearly subcylindrical, without a pedicel, apex rounded, with or without apical structures, sometimes hymenial jelly reddish in Lugol's solution, embedded in a gelatinous matrix. Ascospores overlapping 2-3-seriate, ellipsoid to fusiform, tapering towards both ends, hyaline or pale grey to lightly brown, 0-multi-trans-septate, not constricted or slightly constricted at the septa, thin-walled, with or without gelatinous sheath, guttulate. Asexual morph: Undetermined.

Type species - Epibryon plagiochilae (Gonz. Frag.) Döbbeler

Notes - The monotypic Epibryon Döbbeler was introduced by Döbbeler (1978) to accommodate E. plagiochilae (Gonz. Frag.) Döbbeler, which has globose or subglobose, setose ascomata and hyaline to brown ascospores; the hymenium gel stains red in Lugol's solution (Döbbeler 1978). Döbbeler (1978) proposed that Epibryon is a polyphyletic assemblage of morphologically diverse species. Epibryon has been placed in Pseudoperisporiaceae (Dothideomycetes) by morphological characters (Lumbsch \& Huhndorf 2007, Hyde et al. 2013, Wijayawardene et al. 2014). Subsequently, Stenroos et al. (2010) and Gueidan et al. (2014) regarded Epibryon as a polyphyletic genus based on molecular data. Phylogenetically, most species of Epibryon, together with the type species E. plagiochilae formed a highly supported distinct clade in Chaetothyriales (Gueidan et al. 2014). Members of Epibryon are mostly biotrophic parasites of bryophytes such as Sphagnum and non-symptomatic lichens, and sometimes are saprobes (Döbbeler 1978, U'Ren et al. 2010, Gueidan et al. 2014, Döbbeler 2016, Muggia et al. 2016, Darmostuk \& Khodosovtsev 2019). Epibryon comprises 46 species (Species Fungorum 2021) with sexual morphs, and some melanized asexual morphs isolated from rocks or plants.

Epibryon plagiochilae (Gonz. Frag.) Döbbeler, Mitt. bot. StSamml., Münch. 14: 293 (1978)

三 Coleroa casaresii var. plagiochilae Gonz. Frag. [as 'casaresi'], Mém. R. Soc. Española Hist. Nat. 11(3): 108 (1919)

Index Fungorum number: IF313925, Facesoffungi number: FoF 03720

Description: see Boonmee et al. (2017)

Material examined - Austria, Steiermark, Grazer Bergland, Dürrbachgraben östlich GrazAndritz, reichlich, on leaves of Plagiochilae asplenioidis (L. em. Tayl.) Dum. (Plagiochilaceae), July 1972, J. Poelt, Inv. Nr. 88-89 (DigiBota ID 266896, GZU 000291905).

\section{Ecological and economic significance of Epibryaceae}

Species in Epibryaceae have a widespread distribution in Australia, Europe, Japan, New Zealand and North and South America and include saprobes on plants that play important roles in the recycling of organic matter. Most species are regarded as biotrophic parasites of algae, mosses, or asymptomatic on lichens (Döbbeler 1978, U'Ren et al. 2010, Gueidan et al. 2014, Döbbeler, 2016, Muggia et al. 2016, Darmostuk \& Khodosovtsev 2019). Taxa decompose the lower parts of plants.

Herpotrichiellaceae Munk, Dansk bot. Ark. 15(no. 2): 131 (1953)

Index Fungorum number: IF80856

Type - Herpotrichiella Petr.

Notes - Munk (1953) introduced Herpotrichiellaceae to accommodate Herpotrichiella based on the type species $H$. moravica. The family Herpotrichiellaceae has the largest number of species in 
Chaetothyriales (Wijayawardene et al. 2017, Quan et al. 2020). Species of Herpotrichiellaceae are characterized by superficial, setose, ostiolate, small ascomata with short and extending periphyses near or over the ostiole, bitunicate asci with a thickened endotunica and greenish-grey to brown, 1-multi transversely septate ascospores, rarely with longitudinal septa (von Arx \& Müller 1975, Barr 1976, 1991, Samuels \& Müller 1978, Müller et al. 1987, Untereiner et al. 1995). The asexual morphs of Herpotrichiellaceae are dematiaceous, black yeasts (Müller et al. 1987, Untereiner et al. 1995, Untereiner \& Naveau 1999, Crous et al. 2007, Untereiner et al. 2008, de Hoog et al. 2011, Réblová et al. 2013, Gueidan et al. 2014, Liu et al. 2015, Dong et al. 2018, Untereiner 2020). It is difficult to distinguish species, especially the dematiaceous asexual morphs, based on limited features, and therefore molecular sequences are essential for species delimitation.

Before molecular data, the systematics of Herpotrichiellaceae was confused. Munk (1953) recognized that species in Herpotrichiellaceae should be similar to species in Coenosphaeria and Trichometasphaeria in Dothideomycetes. Müller \& von Arx (1962) and Bigelow \& Barr (1963) rejected the classification of Herpotrichiellaceae and placed the type genus Herpotrichiella in Pleosporales, Dothideomycetes. Herpotrichiellaceae was considered to be related to Capnodiales and Dothideales in Dothideomycetes, until Barr (1976, 1987) and Sivanesan (1984) regarded Herpotrichiellaceae is closely related to Chaetothyriales. In this study, 18 recognized genera are accepted in this family.

Petrak (1914) introduced Herpotrichiella with $H$. moravica as the type species. Untereiner et al. (1995) compared two collections CBS 125.88 and CBS 522.79 (identified as H. moravica), and found that they are morphologically indistinguishable. Subsequently, H. moravica was considered as a synonym of Capronia pilosella (Untereiner 1997). Thus, Quan et al. (2020) synonymized Herpotrichiella under the older name Capronia with the type species Capronia sexdecimspora. In their study, because of the lack of molecular data of Capronia sexdecimspora, they considered C. pilosella (AFTOL 657) as a reference for the family. We follow Quan et al. (2020) to synonymize Herpotrichiella under the older name Capronia.

\section{Other genera included:}

Aculeata W. Dong, H. Zhang \& K.D. Hyde, Mycol. Progr. 17(5): 622 (2018)

Index Fungorum number: IF554259, Facesoffungi number: FoF 04111, 1 morphological species (Species Fungorum 2021), 1 species with molecular data.

Type species - Aculeata aquatica W. Dong, H. Zhang \& K.D. Hyde

Saprobic on submerged wood. Colonies sporodochial, scattered, punctiform, black, granular, glistening. Mycelium mostly immersed in the substratum, consisting of branched, septate, subhyaline to pale brown, smooth hyphae. Sexual morph: Undetermined. Asexual morph: Conidiophores indistinct. Conidiogenous cells monoblastic, holoblastic, integrated, terminal, determinate, hyaline to light olive, pyriform or obovoid. Conidia acrogenous, solitary, subhyaline to light olive, vesiculate, smooth at first, progressively becoming olive, crucially septate, finally becoming olive to brown, muriform, moderately constricted at the septa, darker and thicker at septa, aculeate, bearing densely packed, subulate, obtuse, brown to black spines around conidia, ellipsoid or oval in surface view, clavate in lateral view, composed of a light-colored, cuneiform basal cell, thick-walled (Dong et al. 2018).

Notes - Aculeata W. Dong et al. was introduced to accommodate A. aquatica W. Dong et al. which has short or indistinct conidiophores and oval, muriform conidia. The asexually typified genera in Herpotrichiellaceae, i.e. Cladophialophora, Fonsecaea, are dematiaceous black yeasts with unicellular conidia in chains, or fused and bent in chains and may be related to Aculeata (Dong et al. 2018). Aculeata resembles Melanoctona in having short conidiophores and muriform conidia, while species of Aculeata have a vesiculate wall with densely packed spines versus being smooth-walled in Melanoctona (Tian et al. 2016, Dong et al. 2018).

Aculeata aquatica W. Dong, H. Zhang \& K.D. Hyde, Mycol. Progr. 17(5): 622 (2018) Index Fungorum number: IF554261, Facesoffungi number: FoF 04112 
Description: see Dong et al. 2018

Type material - Thailand, Chiang Rai, Pong Phra Bat, on submerged wood, 10 May 2011, Huang Zhang, i21 (MFLU 11-1094, holotype), ex-type living culture MFLUCC 11- 0529.

Atrokylindriopsis Y.R. Ma \& X.G. Zhang, Mycol. Progr. 14: 2 (2015)

Index Fungorum number: IF811416, Facesoffungi number: FoF 10367, 1 morphological species (Species Fungorum 2021), 1 species with molecular data.

Saprobic on dead branches of an unidentified broadleaf tree in terrestrial habitats. Colonies effuse, hairy, brown. Mycelium immersed to superficial, composed of branched, pale brown to brown, septate, smooth-walled hyphae. Sexual morph: Undetermined. Asexual morph: hyphomycetous. Conidiophores macronematous, erect, unbranched, cylindrical, brown, septate, straight or slightly flexuous, smooth-walled, thick-walled. Conidiogenous cells terminal, integrated, enteroblastic, phialidic, brown, smooth-walled. Conidia solitary, acrogenous, broadly cylindrical or rounded-cubical, pale brown to brown, longitudinally 3-euseptate, straight or curved, with a setula at each corner, attached to the conidiogenous locus at the midpoint of their long side and giving the appearance of a 'T', smooth-walled (Ma et al. 2015).

Type - Atrokylindriopsis setulosa Y.R. Ma \& X.G. Zhang, Mycol. Progr. 14: 3 (2015)

Index Fungorum number: IF811417; Facesoffungi number: FoF 10368

Notes - Atrokylindriopsis Y.R. Ma \& X.G. Zhang was established by Ma et al. (2015) to accommodate A. setulosa Y.R. Ma \& X.G. Zhang associated with dead branches of an unidentified broadleaf tree in China. It is characterized by monophialidic conidiogenous cells and pigmented, septate, setulate conidia that are attached to conidiophores at the midpoint of their long side during conidiogenesis, giving the appearance of a ' $\mathrm{T}$ '. Ma et al. (2015) suggested placing Atrokylindriopsis in Chaetothyriales, but no family was assigned. Wijayawardene et al. (2020) placed this genus in an uncertain phylogenetic position in Chaetothyriales genera incertae sedis. Quan et al. (2020) showed that A. setulosa clustered with Capronia fungicola in Herpotrichiellaceae. In our study, we include the type species of Atrokylindriopsis and the combined ITS and LSU phylogenetic analysis shows that A. setulosa (HMAS245592) forms a sister group with Marinophialophora garethjonesii (MFLUCC 16-1449) with 0.93 BY PP support in Herpotrichiellaceae (Fig. 1).

Brycekendrickomyces Crous \& M.J. Wingf., Persoonia 22: 141 (2009)

Index Fungorum number: IF509515, Facesoffungi number: FoF 10369, 1 morphological species (Species Fungorum 2021), 1 species with molecular data.

Type species - Brycekendrickomyces acaciae Crous \& M.J. Wingf., Persoonia 22: 141 (2009)

Mycelium consisting of branched, septate, smooth, pale brown hyphae. Sexual morph: Undetermined. Asexual morph: hyphomycetous. Conidiophores solitary, erect, cylindrical, straight to somewhat flexuous, basal cell bulbous, without rhizoids, stalk medium to dark brown, smooth, transversely euseptate, upper cell giving rise to (1-)2-4(-6) conidiogenous cells. Conidiogenous cells subcylindrical to allantoid or doliiform, straight to gently curved, pale brown, polyblastic, proliferating sympodially. Conidia hyaline, aggregating in slimy mass (never in chains), ellipsoid, apex subobtuse, base subtruncate (Crous et al. 2009).

Notes - Crous et al. (2009) introduced Brycekendrickomyces Crous \& M.J. Wingf. to accommodate the type species $B$. acaciae Crous \& M.J. Wingf. which has a simple conidiophore branching system, and ellipsoid conidia which are not in chains. Crous et al. (2009) compared the morphology of Brycekendrickomyces with Argopericonia (Incertae sedis), Haplographium (Hyaloscyphaceae, Helotiales, Leotiomycetes) and Lauriomyces (Lauriomycetaceae, Lauriomycetales, Incertae sedis). Brycekendrickomyces have a simple conidiophore branching system, while Haplographium and Lauriomyces have an intricate series of branched conidiophores and conidia arising in chains. Argopericonia has apical conidiogenous heads, and catenate conidia with a prominent, globose guttule (Crous et al. 2009). Phylogenetically, Brycekendrickomyces acacia (CBS 124104) 
formed a distinct clade in Chaetothyriales with 92\% ML BS, 1.00 BY PP support in this study (Fig. 1). We maintain Brycekendrickomyces in Herpotrichiellaceae pending further studies.

Brycekendrickomyces acaciae Crous \& M.J. Wingf., Persoonia 22: 141 (2009)

Fig. 19

Index Fungorum number: IF509517; Facesoffungi number: FoF 10370

Description - see Crous et al. 2009

Type material - Indonesia, Pelalawan, living leaves of Acacia auriculiformis Benth. (Leguminosae), March 2008, leg. M.J. Wingfield, isol. P.W. Crous (CBS H-20198, holotype), culture ex-type CPC $15078=$ CBS 124104 .

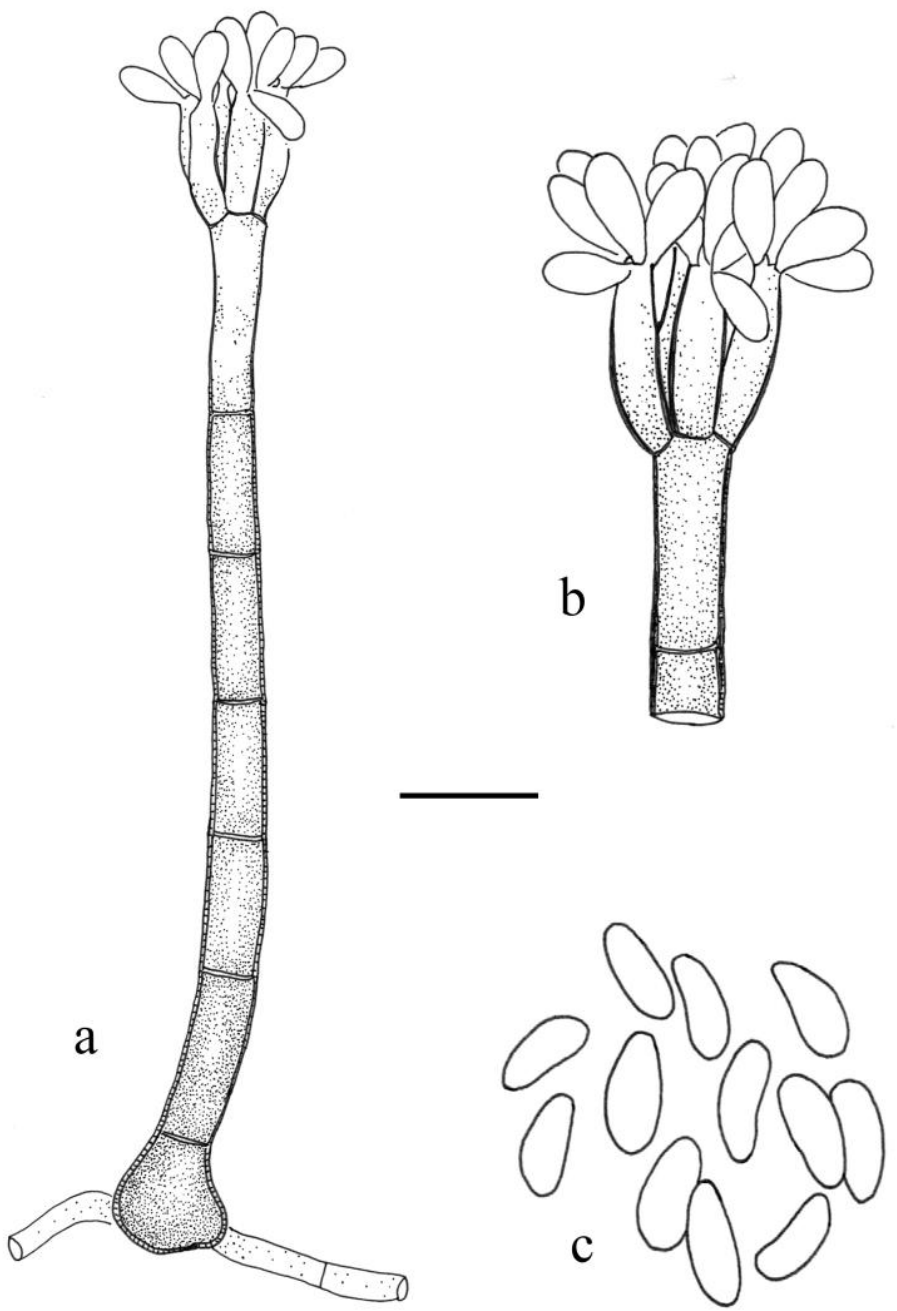

Figure 19 - Brycekendrickomyces acaciae (CBS 124104, holotype, redrawn from Crous et al. 2009). a Cylindrical, transversely euseptate conidiophore. b Subcylindrical conidiogenous cells with conidia. c Ellipsoid conidia. Scale bar: $10 \mu \mathrm{m}$.

Capronia Sacc., Syll. fung. (Abellini) 2: 288 (1883)

$=$ Herpotrichiella Petr., Annls mycol. 12(5): 472 (1914)

Index Fungorum number: IF815, Facesoffungi number: FoF 10371, 79 morphological species (Species Fungorum 2021), 18 species with molecular data.

Type species - Capronia sexdecimspora (Cooke) Sacc. [as 'sexdecemspora']

Saprobic on cone of Pinus sylvestris. Sexual morph: Ascomata perithecioid, arising singly, dispersed, superficial, immersed only at the base when mature, subglobose, black, smooth-walled, but with aseptate or 1-multi septate, unbranched, dark brown setae, arising from the upper part, ostiolate. Setae smooth-walled, rounded at the apex and hardly attenuated or tapering to the end. Ostiole lateral, 
black, flattened. Peridium thick, composed of multi-layered, hyaline to brown cells of textura angularis. Hamathecium gelatinized, lacking pseudoparaphyses. Asci 8-spored or multi-spored, bitunicate, obpyriform to broadly clavate, wall apically thickened, J-. Ascospores overlapping, irregularly biseriate, oval to fusiform, muriform, hyaline to yellow-brown or grey, 1-7-trans-septate, constricted at the septa, with or without longitudinial septa, some slightly curved, smooth-walled, with or without guttules, without a gelatinous sheath or appendages. Asexual morph: hyphomycetous.

Notes - Capronia is cosmopolitan and includes saprobes on rooting or decaying plant tissues, taxa on the thalli of lichens on Ascomycota and Basidiomycota and hypersaprobes, fungicolous and lichenicolous taxa (Cooke 1871, Munk 1957, Barr 1987, 1991, Müller et al. 1987, Untereiner 1997 , 2000, Halic1 et al. 2010, Sun et al. 2019). With the exception of C. glabra and C. episphaeria, the genus is characterized by setose ascomata with periphysate ostioles, bitunicate asci and 1-multi-septate or muriform ascospores (Barr 1991, Hsieh et al. 1997, Untereiner 1997, 2000, Halic1 et al. 2010). Asexual morphs of Capronia are black yeasts and related to species in Exophiala, Ramichloridium, the Rhinocladiella species complex and phialophora and cladophialophora-like species (Müller et al. 1987, Untereiner et al. 1995, Untereiner 2020). However, all the sexual and asexual links should be confirmed based on culture and DNA molecular sequences. Establishing the asexual and sexual morph connections should be a focus of future work.

Capronia sexdecimspora (Cooke) Sacc. [as ‘sexdecemspora'], Syll. fung. (Abellini) 2: 289 (1883)

ESphaeria sexdecimspora Cooke, Handb. Brit. Fungi 2: 860 (1871)

Fig. 20

For synonyms see Species Fungorum

Index Fungorum number: IF195056; Facesoffungi number: FoF 10372

Saprobic on cone of Pinus sylvestris. Sexual morph: Ascomata 96-150 $\mu \mathrm{m}$ diam, perithecioid, arising singly, dispersed, superficial, immersed only at the base when mature, subglobose, black, smooth-walled, but with aseptate, unbranched, dark brown setae, arising from the upper part, ostiolate. Setae 30-38 $\times 2-3 \mu \mathrm{m}(\mathrm{x}=35 \times 2.4 \mu \mathrm{m}, \mathrm{n}=10)$, smooth-walled, rounded at the apex and tapering to the ends. Ostiole lateral, black, flattened. Peridium thick, composed of multi-layered, hyaline to brown cells of textura angularis, the outermost layers brown to dark brown. Hamathecium lacking paraphyses. Asci (40-)43-63(-72) $\times(8-) 9-15(-17) \mu \mathrm{m}(\mathrm{x}=55 \times 13 \mu \mathrm{m}, \mathrm{n}=10), 8$-spored, bitunicate, obpyriform to broadly clavate. Ascospores $(7-) 8-16(-18) \times 5.5-7.5 \mu \mathrm{m}(\mathrm{x}=14.3 \times 6.2 \mu \mathrm{m}, \mathrm{n}=20)$, overlapping, irregularly biseriate, oval to fusiform, muriform, hyaline to yellow-brown, 3-septate, constricted at the septa, with a single longitudinal septum, smooth-walled, without a gelatinous sheath or appendages. Asexual morph: Undetermined.

Material examined - UK, Scotland, Perthshire, on Pinus sylvestris L. (Pinaceae), 21 June 1978, D.W. Math (IMI 230725).

Cladophialophora Borelli, Proc. 5th International Conference on Mycoses: 355 (1980)

Index Fungorum number: IF7677, Facesoffungi number: FoF 10373, 38 morphological species (Species Fungorum 2021), 12 species with molecular data.

Type species - Cladophialophora carrionii (Trejos) de Hoog, Kwon-Chung \& McGinnis

Pathogenic, lichenicolous, saprobic, parasitic, endophytic, fungicolous and rock-inhabiting on a variety of hosts. Colonies olivaceous, powdery to hairy. Sexual morph: Undetermined. Asexual morph: hyphomycetous. Fertile hyphae smooth-walled, hyaline to pale brown, irregularly septate. Conidiophores absent or present, semi-macronematous, pale olivaceous to brown, septate, oblong to cylindrical. Conidial chains forming laterally or terminally on undifferentiated hyphae, branched or unbranched, acropetal. Conidia sessile or ascending, subspherical, limoniform, fusiform, ellipsoidal to ovoidal, pale olivaceous green, aseptate, conidial scars slightly pigmented, smooth- and melanizedwalled, with pale scars at the narrow ends. Phialides (asexual genus Phialophora) absent or present, flask-shaped, funnel-shaped, collarettes occasionally present. Phialoconidia absent or present, hyaline, subspherical, aseptate. Chlamydospores, yeast cells or muriform cells absent, or occasionally present, 
thick-walled, brown (Borelli 1980, de Hoog et al. 1995, Badali et al. 2008).

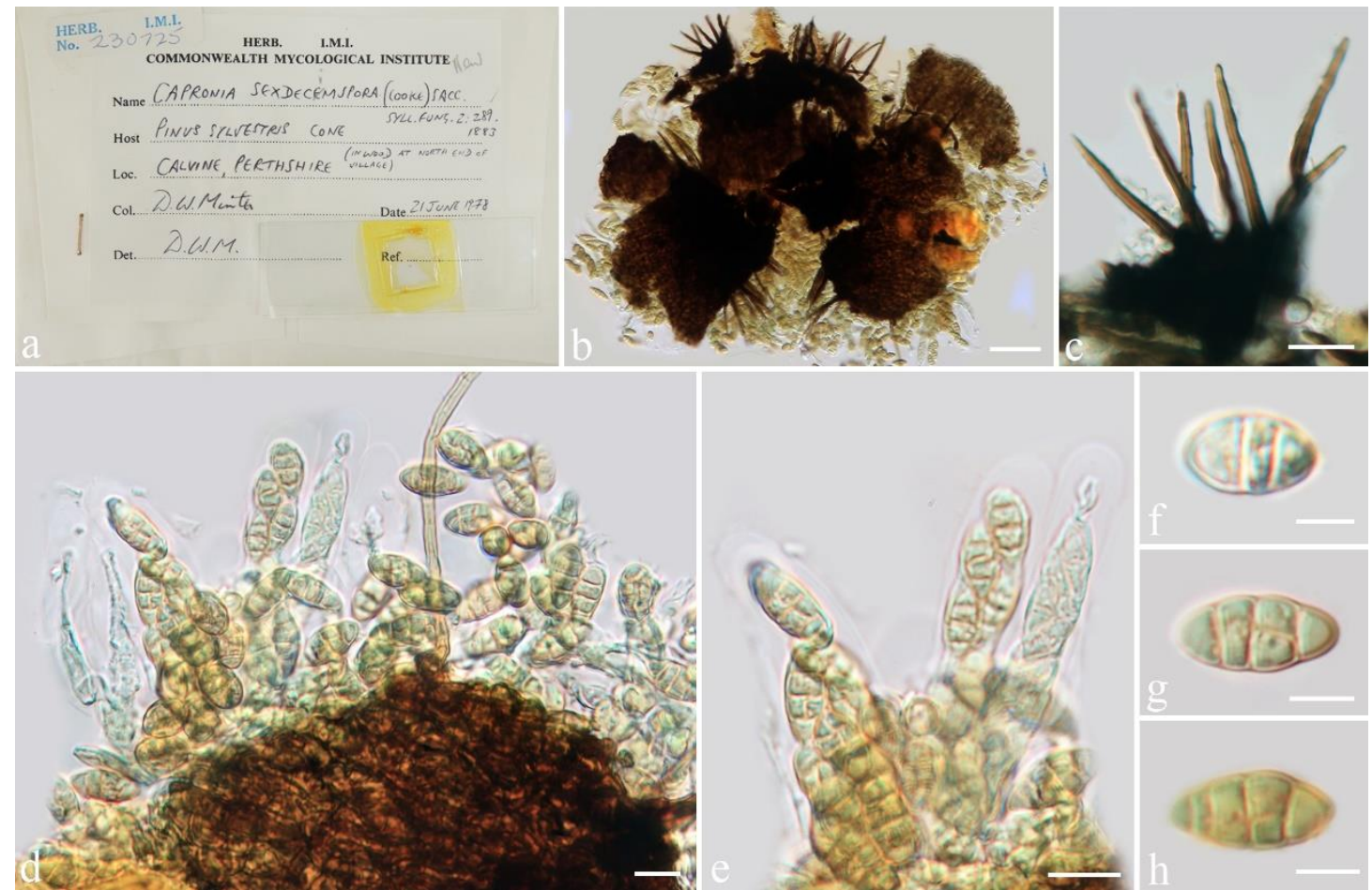

Figure 20 - Capronia sexdecimspora (IMI 230725). a Envelop, slide and collection information of Capronia sexdecimspora. b Squash mount of ascomata. c Setae. d, e Asci with ascospores. $\mathrm{f}-\mathrm{h}$ Ascospores. Scale bars: $\mathrm{b}=50 \mu \mathrm{m}, \mathrm{c}=20 \mu \mathrm{m}, \mathrm{d}, \mathrm{e}=10 \mu \mathrm{m}, \mathrm{f}-\mathrm{h}=5 \mu \mathrm{m}$.

Notes - Cladophialophora Borelli was introduced by Borelli (1980) to accommodate asexual, melanized taxa. Species of Cladophialophora have conidia which are produced in branched chains on poorly differentiated hyphae (Trejos 1954, de Hoog et al. 2007, Badali et al. 2008). The type species, $C$. carrionii, is the only species that has phialophora-like, phialidic conidiogenous cells in addition to conidial chains (Borelli 1980, de Hoog et al. 1995, Badali et al. 2008). Cladophialophora is polyphyletic in Chaetothyriales and closely related to asexually typified genera Exophiala J.W. Carmich., Fonsecaea Negroni, Knufia L.J. Hutchison \& Unter., Phialophora Medlar, and Rhinocladiella Nannf.. Species of Capronia have been recorded as the sexual morphs of Cladophialophora (de Hoog et al. 2007, Badali et al. 2008, Feng et al. 2014). Phylogenetically, the majority of species of Cladophialophora separate into two main clades (carrionii- and bantiana-clades). Cladophialophora is ecological diverse. The genus includes species causing opportunistic diseases of humans and other mammals, such as $C$. bantiana (Sacc.) de Hoog et al., C. carrionii (Trejos) de Hoog et al., C. devriesii (A.A. Padhye \& Ajello) de Hoog et al. and C. samoënsis Badali et al. (Mitchell et al. 1990, Mendoza et al. 1993, Tintelnot et al. 1995, McGinnis et al. 1999, Badali et al. 2008, 2009, Lastoria et al. 2009). Cladophialophora cladoniae (Diederich) Diederich, C. hawksworthii (Etayo \& Diederich) Diederich, C. megalosporae Diederich, C. normandinae (Diederich \& Etayo) Diederich and C. parmeliae (Etayo \& Diederich) Diederich \& Unter. are lichenicolous (Diederich 2010, Diederich et al. 2013). Cladophialophora species are also epiphytes, saprobes, pathogens, endophytes, soil and environmental inhabitants and may occupy different ecological niches (Iwatsu 1984, Crous et al. 2007, 2013, de Hoog et al. 2007, Badali et al. 2011, Park \& Shin 2011, Feng et al. 2014, Rashmi et al. 2019).

Cladophialophora carrionii (Trejos) de Hoog, Kwon-Chung \& McGinnis, Journal of Medical and Veterinary Mycology 33: 345 (1995)

$\equiv$ Cladophialophora ajelloi Borelli, Proc. 5th International Conference on Mycoses: 335 (1980)

For other synonyms see Index Fungorum

Index Fungorum number: IF412794 
Description - see Trejos (1954), de Hoog et al. (2007) and Badali et al. (2008)

Type material - Australia, isolated from human chromoblastomycosis, 1951, Chester W. Emmons, Trejos 27 (CBS H-18465, lectotype), CBS 160.54 = ATCC 16264 = CDC A-835 = MUCL 40053, ex-type.

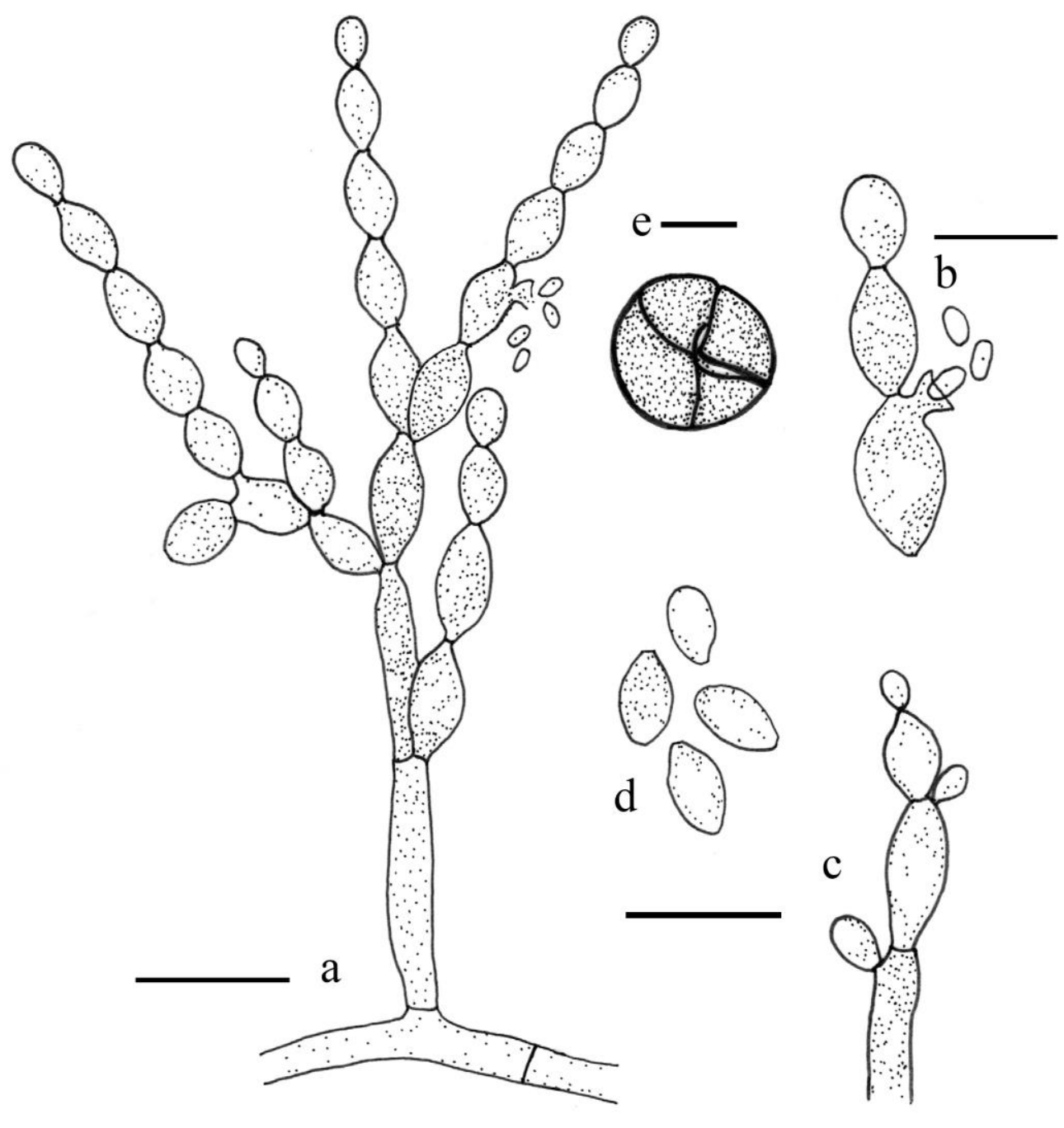

Figure 21 - Cladophialophora carrionii (CBS 160.54, ex-type, a-d redrawing from de Hoog et al. 2007, e redrawing from Badali et al. 2008). a, c Conidiophore and conidial chains. b Conidiophores with conidiogenous cells. d Conidia. e Muriform cells. Scale bar: $\mathrm{a}-\mathrm{e}=10 \mu \mathrm{m}$.

Exophiala J.W. Carmich., Sabouraudia 5: 122 (1966)

Index Fungorum number: IF8233, Facesoffungi number: FoF 10374, 51 morphological species (Species Fungorum 2021), 17 species with molecular data.

Pathogenic, saprobic, endophytic and fungicolous on a variety of hosts. Vegetative hyphae branched, unswollen, forming protruding fascicles. Hyphae hyaline to pale brown, irregularly septate, smooth-walled, thin-walled, sometimes pigmented. Sexual morph: Undetermined. Asexual morph: hyphomycetous. Conidiophores absent or present, erect, multicellular, brown, septate, oblong to cylindrical. Conidiogenous cells sympodial, lateral, intercalary or terminal, mono- or polyphialidic, ovoid to clavate, subhyaline to pale brown, septate. Conidia ellipsoidal, cylindrical, allantoid, hyaline to brown, aseptate or 1-septate, with a conspicuous conidial scar, smooth-walled, with small oil drops. Chlamydospores absent (Carmichael 1966). 
For synomyms see Species Fungorum

Index Fungorum number: IF119468; Facesoffungi number: FoF 10375

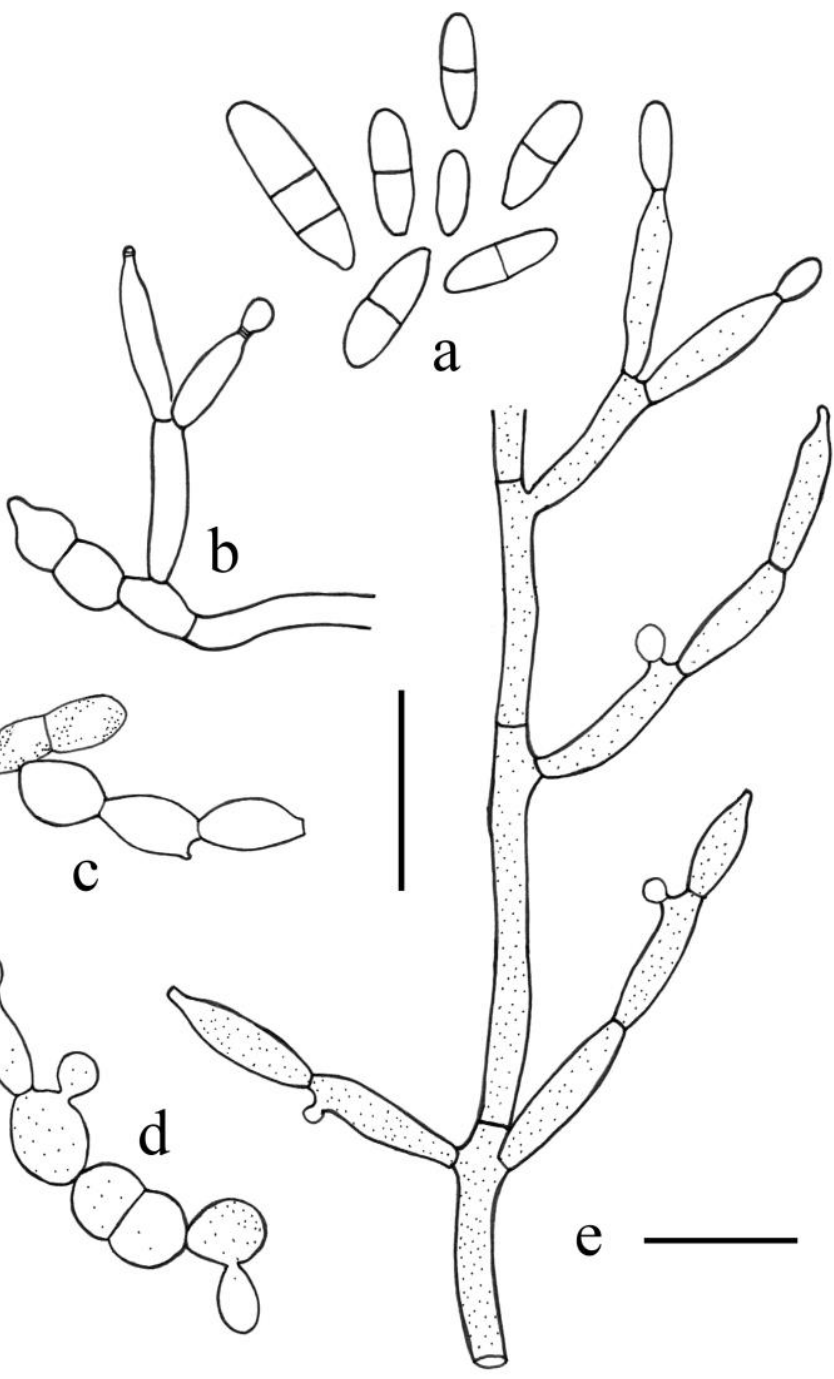

Figure 22 - Exophiala salmonis (redrawn from Seifert et al. 2011). a Conidia. b, d Conidiogenous cells. c Conidiogenous cells with conidia. e Conidiophore. Scale bar: $\mathrm{a}-\mathrm{e}=10 \mu \mathrm{m}$.

Notes - The black yeast genus Exophiala J.W. Carmich. was established by Carmichael (1966) to accommodate Exophiala salmonis J.W. Carmich. Species of Exophiala are characterized by brown, aseptate to 1-septate conidia, forming successively from the apex of the sporogenous cells and forming protruding fascicles, aggregating in slime balls (Carmichael 1966). Members of Exophiala have been linked to the sexual genus Capronia (Herpotrichiellaceae, Chaetothyriales) (Carmichael 1966, Hironaga et al. 1981, de Hoog et al. 2011).

Exophiala has remarkable ecological traits. Species of Exophiala appears to be an opportunistic pathogen of animals, including humans (Richards et al. 1978, de Hoog et al. 2011, Najafzadeh et al. 2013, Wen et al. 2016) and environmental taxa in anthropogenic habitats or natural environments (Ávila et al. 2005, Bukovská et al. 2010, de Hoog et al. 2011, Ferrari et al. 2011, Isola et al. 2013), endophytes from roots (Ali et al. 2016, Maciá-Vicente et al. 2016) and saprobes or fungicolous taxa, occurring on a wide range of substrates (Madrid et al. 2016). 
Exophiala species are difficult to identify by morphology because of the polymorphic morphology, therefore, phylogenetic affinities and ecological traits are necessary for species identification (de Hoog et al. 2011, Isola et al. 2013, Maciá-Vicente et al. 2016).

Type material - Canada, Alberta, isolated from the brain of Salmo clarkii Richardson (Salmonidae), 1966, J.W. Carmich. (CBS 157.67, ex-type).

Fonsecaea Negroni, Revista Inst. Bacteriol. 'Dr. Carlos G. Malbrán’ 7: 424 (1936)

Index Fungorum number: IF8264, Facesoffungi number: FoF 10376, 8 morphological species (Species Fungorum 2021), 8 species with molecular data.

Type species - Fonsecaea pedrosoi (Brumpt) Negroni, Revista Inst. Bacteriol. 'Dr. Carlos G. Malbrán’: 424 (1936)

三 Hormodendrum pedrosoi Brumpt, Précis Parasitol. hum., Edn 3 (Paris): 1105 (1922)

For synonyms see Species Fungorum

Pathogenic on a variety of plants, and organs of animals, including humans. Colonies restricted or moderately expanding, powdery to velvety, olivaceous brown to olivaceous black. Vegetative hyphae branched, pale olivaceous brown, septate, smooth-walled. Sexual morph: Undetermined. Asexual morph: hyphomycetous. Conidiophores absent or present, branched or unbranched, erect, slightly differentiated, oblong to cylindrical, olivaceous brown. Conidiogenous cells sympodial, lateral, intercalary or terminal, enteroblastic, phialidic, pale olivaceous, septate, with prominent denticles. Conidia ellipsoidal, cylindrical, in short chains, pale olivaceous brown, aseptate, with a conspicuous conidial brown scar, smooth-walled. Chlamydospores absent or present, globose (de Hoog et al. 2000a, Najafzadeh et al. 2010a, b).

Fonsecaea pedrosoi (Brumpt) Negroni, Revista Inst. Bacteriol. 'Dr. Carlos G. Malbrán': 424 (1936)

Index Fungorum number: IF253857; Facesoffungi number: FoF 10377

Fig. 23

Type material - Isolated from a human, 1922 (holotype).

Notes - Fonsecaea species are important clinical taxa that cause human chromoblastomycosis and phaeohyphomycosis in tropical and subtropical climates (de Hoog et al. 2007, Najafzadeh et al. 2009, 2010a, b, 2011, Xi et al. 2009, Koo et al. 2010). Fonsecaea lacks budding cells, sympodial conidiogenous cells and has conidia arranged in short chains, melanized conidiophores with cylindrical denticles and aseptate conidia (de Hoog et al. 2000a, Najafzadeh et al. 2010a, b). Fonsecaea resembles Cladophialophora and also always clusters together in phylogenetic trees, but Cladophialophora differs in having very long conidial chains. Fonsecaea species lack a known sexual morph. Currently, Fonsecaea comprises eight species, most being potential etiologic agents of human chromoblastomycosis and phaeohyphomycosis (Surash et al. 2005, Takei et al. 2007, Vicente et al. 2008, 2014, Najafzadeh et al. 2009, 2010b, Koo et al. 2010).

Marinophialophora J.F. Li, Phookamsak \& K.D. Hyde, Phytotaxa 345(1): 4 (2018)

Index Fungorum number: IF552733, Facesoffungi number: FoF 02753, 1 morphological species (Species Fungorum 2021), 1 species with molecular data.

Saprobic on a decaying mangrove wood associated with Halocyphina sp. Hyphae immersed to superficial, branched, hyaline to subhyaline, septate, smooth-walled, thin-walled. Sexual morph: Undetermined. Asexual morph: hyphomycetous. Conidiophores single or caespitose, macronematous, mononematous, unbranched, erect, oblong to cylindrical, hyaline to subhyaline, aseptate, arising from hyphae. Conidiogenous cells integrated, terminal or intercalary, enteroblastic, phialidic, globose to ellipsoidal, hyaline to subhyaline, without a conspicuous collarette. Conidia globose to subglobose, hyaline to subhyaline, aseptate, borne basipetally, developing in unbranched or branched chains, smooth-walled. Chlamydospores absent (Li et al. 2018).

Type species - Marinophialophora garethjonesii J.F. Li, Phookamsak, Dayar. \& K.D. Hyde, Phytotaxa 345(1): 4 (2018)

Index Fungorum number: IF552734 

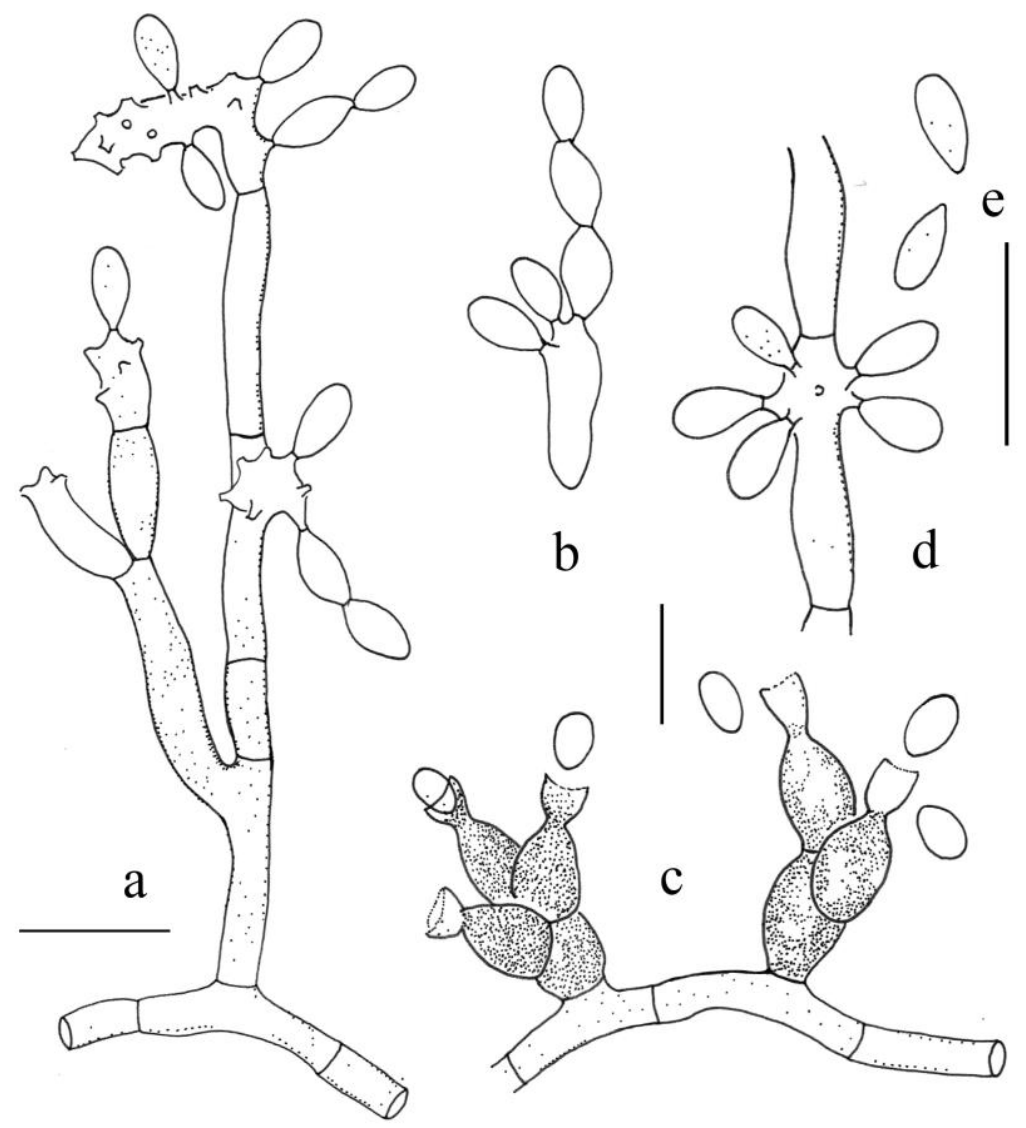

Figure 23 - Fonsecaea pedrosoi (redrawn from Seifert et al. 2011). a Conidiophore. b, d Conidiogenous cells with conidia. c Phialides. e Conidia. Scale bar: $\mathrm{a}-\mathrm{e}=10 \mu \mathrm{m}$.

Notes - Marinophialophora J.F. Li et al. was introduced by Li et al. (2018) to accommodate M. garethjonesii J.F. Li et al. based on morphology and phylogenetic analysis. It was associated with Halocyphina from marine habitats in Thailand. This genus is characterized by mononematous, macronematous conidiophores, hyaline, phialidic conidiogenous cells without conspicuous collarettes and subhyaline, aseptate conidia. Marinophialophora is a monotypic genus and resembles Cladophialophora and Phialophora (Herpotrichiellaceae, Chaetothyriales) in having similar conidiophores, phialidic conidiogenous cells and conidia in chains. Marinophialophora mainly differs in having conidia borne in basipetally, branched chains and septate conidiophores. Marinophialophora garethjonesii (MFLUCC 16-1449) clusters with Atrokylindriopsis setulosa (HMAS245592) in Herpotrichiellaceae (Chaetothyriales) with high statistical support (1.00 BYPP) (Fig. 1).

Melanoctona Qing Tian, Doilom \& K.D. Hyde, Cryptog. Mycol. 37(4): 487 (2016)

Index Fungorum number: IF552157, Facesoffungi number: FoF 02225, 1 morphological species (Species Fungorum 2021), 1 species with molecular data.

Saprobic on decaying wood in terrestrial habitats. Colonies superficial, effuse, scattered, dark brown to black. Sexual morph: Undetermined. Asexual morph: hyphomycetous. Conidiophores mononematous, macronematous, unbranched, erect, straight or flexuous, smooth, dark brown. Conidiogenous cells integrated, sympodially proliferating, terminal and intercalary, enteroblastic, phialidic, pale brown or subhyaline. Conidia acrogenous, brown to black, ovoid, muriform, rounded at base and apex, smooth-walled.

Type species - Melanoctona tectonae Qing Tian, Doilom \& K.D. Hyde 
Notes - Melanoctona was introduced to accommodate an asexual species in Herpotrichiellaceae and is typified by M. tectonae which forms a distinct clade (Tian et al. 2016). To date, the asexual morphs of Herpotrichiellaceae are predominantly black yeasts with holoblastic, conidiogenous cells which proliferate percurrently and aseptate or septate conidia, and include Cladophialophora, Exophiala, Fonsecaea, Phialophora, Ramichloridium and Rhinocladiella species (Müller et al. 1987, Untereiner et al. 1995, Crous et al. 2007, Gueidan et al. 2014, Liu et al. 2015), and undetermined pyricularia-like taxa (Klaubauf et al. 2014). Species of Exophiala are characterized by brown, aseptate to 1-septate conidia, forming successively from the apex of the sporogenous cell and aggregating in slime balls (Carmichael 1966). Phialophora produces hyaline to pigmented, aseptate conidia, forming from flask-shaped to straight phialides (Harrington \& Mcnew 2003). Cladophialophora has aseptate, hydrophobic conidia and is mostly isolated as clinical fungi (Badali et al. 2011). Fonsecaea has melanized conidiophores with cylindrical denticles and aseptate, acrogenous conidia (de Hoog et al. 2000a). Melanoctona however, has dark brown to black, muriform or multi-septate, acrogenous, conidia. Melanoctona tectonae was isolated from a dead branch of Tectona grandis as a saprobe, while other asexual morphs in Herpotrichiellaceae have been isolated as human pathogens (such as human chromoblastomycosis) (de Hoog et al. 2007). Melanoctona was collected on decaying wood of Tectona grandis in Chiang Rai Province, Thailand and phylogenetic analyses of combined ITS, LSU sequence data place Melanoctona in a distinct lineage in Herpotrichiellaceae (Fig. 1).

Melanoctona tectonae Qing Tian, Doilom \& K.D. Hyde, Cryptog. Mycol. 37(4): 487 (2016)

Index Fungorum number: IF552158; Facesoffungi number: FoF 02226

Fig. 24

Saprobic on decaying wood of Tectona grandis L.f. in terrestrial habitat. Colonies superficial, effuse, scattered, dark brown to black. Sexual morph: Undetermined. Asexual morph: hyphomycetous. Conidiophores $3-6 \mu \mathrm{m}(\overline{\mathrm{x}}=5.2 \mu \mathrm{m}, \mathrm{n}=7)$ wide, mononematous, macronematous, unbranched, erect, straight or flexuous, smooth, dark brown. Conidiogenous cells integrated, sympodially proliferating, terminal and intercalary, enteroblastic, phialidic, pale brown or subhyaline. Conidia $28-39 \times 43-49 \mu \mathrm{m}(\overline{\mathrm{x}}=34.5 \times 47.3 \mu \mathrm{m}, \mathrm{n}=10)$, acrogenous, light brown to black, ovoid, muriform, rounded at base and apex, smooth-walled.

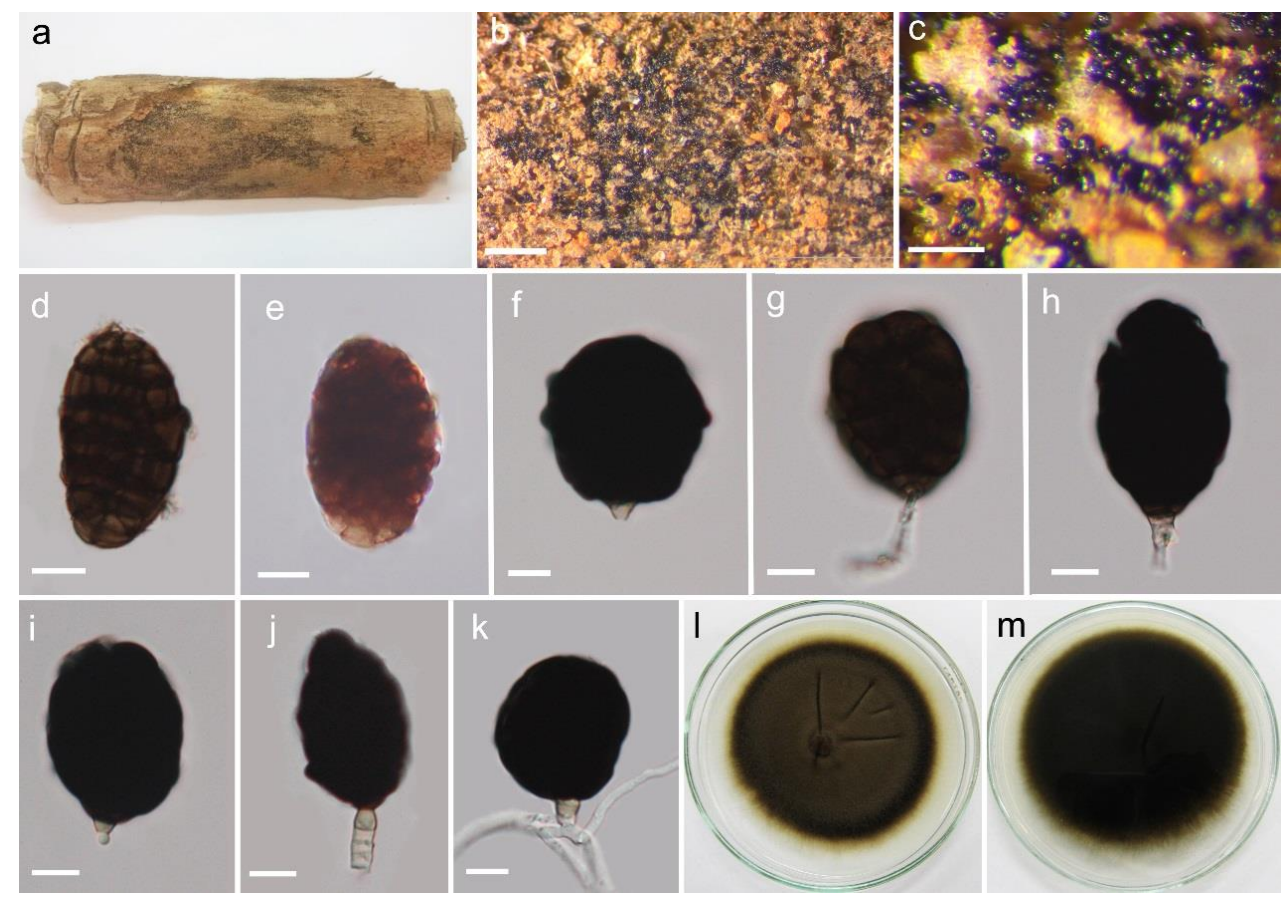

Figure 24 - Melanoctona tectonae (MFLU 15-3528, holotype). a Appearance of fungus on a dead branch of Tectona grandis. b, c Conidia scattered on the surface of the wood. d, e Conidia. 
$\mathrm{f}-\mathrm{j}$ Conidiophores with conidia. $\mathrm{k}$ Germinating conidium. 1 Surface view of culture on PDA. $\mathrm{m}$ Reverse view of culture on PDA. Scale bars: $\mathrm{b}=1000 \mu \mathrm{m}, \mathrm{c}=200 \mu \mathrm{m}, \mathrm{d}-\mathrm{k}=10 \mu \mathrm{m}$.

Culture characteristics - Conidia germinating on PDA within $12 \mathrm{~h}$ and germ tubes produced from both ends. Colonies on PDA, fast-growing, reaching up to $15 \mathrm{~mm}$ diam. in 14 days at $25^{\circ} \mathrm{C}$. Mycelium superficial, circular, hairy, with an entire edge, brown, dark brown at the periphery, completely dark brown from below.

Material examined - Thailand, Chiang Rai Province, Mae Chan District, on a dead branch of Tectona grandis L.f. (Lamiaceae), 1 July 2012, M. Doilom MKT062 (MFLU 15-3528, holotype), ibid., (HKAS 94893, isotype), ex-type living culture, MFLUCC 12-0389, KUMCC 16-0009.

Metulocladosporiella Crous, Schroers, J.Z. Groenew., U. Braun \& K. Schub., Mycol. Res. 110(3): 269 (2006)

Index Fungorum number: IF500224, Facesoffungi number: FoF 10378, 6 morphological species (Species Fungorum 2021), 6 species with molecular data.

Epiphytic on living leaves. Hyphae immersed to superficial, branched, septate, hyaline, subhyaline to pale olivaceous, thin-walled. Sexual morph: Undetermined. Asexual morph: hyphomycetous. Conidiophores macronematous, mononematous, solitary or aggregated, erect, subcylindrical, arising from hyphae, smooth-walled. Conidiogenous cells integrated, terminal, occasionally intercalary, sympodial, polyblastic, with or without conidial scars, subdenticulate, truncate. Conidia in simple and branched chains, ellipsoid, ovoid, subcylindrical, fusiform, subhyaline to pale olivaceous, 0-1-septate, thin-walled, smooth-walled, conidial secession schizolytic. Chlamydospores absent (Crous et al. 2006).

Type species - Metulocladosporiella musae (E.W. Mason) Crous, Schroers, J.Z. Groenew., U. Braun \& K. Schub., Mycol. Res. 110(3): 269 (2006)

Fig. 25

三Cladosporium musae E.W. Mason, in Martyn, Mycol. Pap. 13: 2 (1945)

For synonyms see Species Fungorum

Index Fungorum number: IF500185

Type material - Jamaica, on Musa sp., 7 September 1942, E. B. Martyn [slide ex type coll.] (IMI 7521) - lectotypus hic designates; Honduras, on Musa sp., R.H. Stover (CBS herb. 14788-epitypus hic designatus; culture ex-epitype CBS 161.74 1/4 ATCC 36973).

Notes - Metulocladosporiella Crous et al. was established by Crous et al. (2006) to accommodate Cladosporium musae E.W. Mason which is the causal agent of speckle disease on the banana in Herpotrichiellaceae. The genus is characterized by frequently branched, pigmented conidiophores, holoblastic, subconspicuous to conspicuous conidiogenous loci and subhyaline conidia formed in acropetal, often branched chains (Crous et al. 2006). The phylogenetic analysis based on the ITS and LSU sequence data demonstrates that Metulocladosporiella musae (E.W. Mason) Crous et al. (CBS 161.74) formed a sister group with Arthrophiala arthrospora (D.J. Soares, R.W. Barreto \& U. Braun) W.S. Lisboa et al. (CPC 19480) with 99\% ML BS, 1.00 BYPP support representing as a distinct clade in Chaetothyriales (Fig. 1). In morphology, Metulocladosporiella resembles Cladophialophora in Herpotrichiellaceae. However, Cladophialophora has unbranched, micro- to semimacronematous conidiophores while Metulocladosporiella has branched, macronematous, mononematous conidiophores (Crous et al. 2006). Thus, we maintain Metulocladosporiella in Herpotrichiellaceae pending further studies.

Minimelanolocus R.F. Castañeda \& Heredia, Cryptog. Mycol. 22(1): 7 (2001)

Index Fungorum number: IF28574; Facesoffungi number: FoF 10379, 34 morphological species (Species Fungorum 2021), 10 species with molecular data.

Saprobic on decaying wood in aquatic habitats. Mycelium superficial or partly immersed, comprising septate, pale brown to brown hyphae, smooth-walled hyphae. Colonies superficial on the host, effuse, scattered, hairy, brightly colored, glistening. Sexual morph: Undetermined. Asexual morph: hyphomycetous. Conidiophores mononematous, macronematous, unbranched, 
erect, dark brown and gradually paler towards the apex, straight or flexuous, cylindrical, smooth, septate. Conidiogenous cells holoblastic, integrated, sympodial proliferating, terminal, pale brown to brown or subhyaline to hyaline. Conidia acrogenous, oblong or clavate to fusiform, with or without obtuse ends, hyaline to pale brown or brown, solitary, sometimes with secondary conidia, immature conidia aseptate, multi-septate at maturity, dry, smooth-walled. Conidial secession schizolytic.

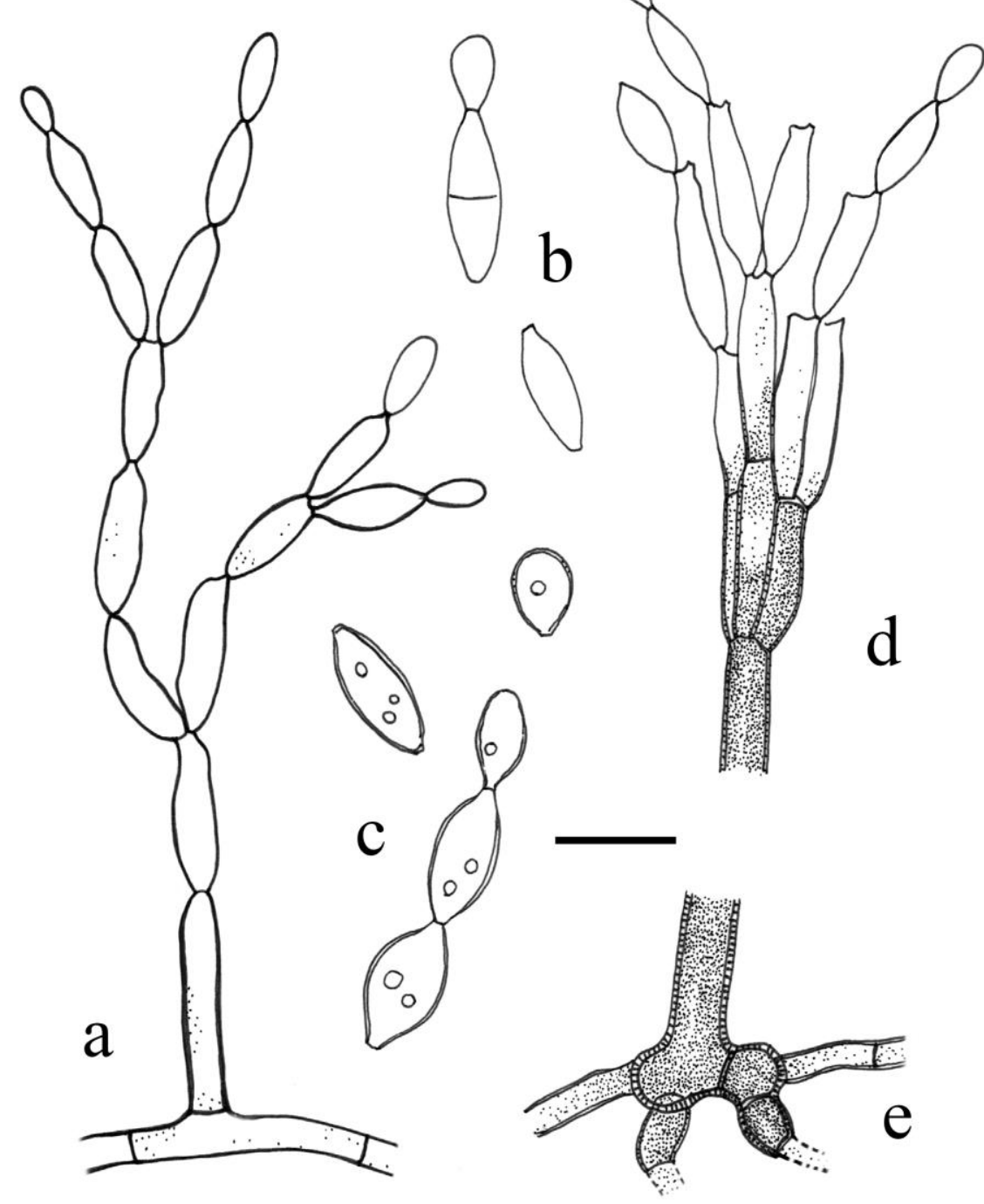

Figure 25 - Metulocladosporiella musae (CBS 161.74, ex-epitype, redrawn from Crous et al. 2006). a Conidiophore. b, d Conidiogenous cells with conidia. c Conidia. e Base of conidiophore on hypha. Scale bar: a-e $=10 \mu \mathrm{m}$.

Type species - Minimelanolocus navicularis (R.F. Castañeda) R.F. Castañeda, in Castañeda Ruiz, Heredia, Reyes, Arias \& Decock, Cryptog. Mycol. 22(1): 9 (2001)

三 Pseudospiropes navicularis R.F. Castañeda, Fungi Cubenses II (La Habana): 10 (1987)

Index Fungorum number: IF474516

Type material - Cuba, Havana, Instituto de Investigaciones Fundamentales en Agricultura Tropical "Alejandro de Humboldt", on fallen leaves of Gesneria sp. (Gesneriaceae), 1987 (Holotype). 
Notes - Minimelanolocus was introduced by Castañeda-Ruiz et al. (2001) and typified by $M$. navicularis based on segregation of some atypical species from Pseudospiropes. The genus is characterized by conspicuous, mononematous, solitary or fasciculate, septate, erect, straight or flexuous, smooth or verrucose, cylindrical, sinuate or geniculate, brown to dark brown conidiophores, with a melanized base and hyaline to brown, oblong, cylindrical, clavate to fusiform, euseptate, acropleurogenous conidia (Castañeda-Ruiz et al. 2001, Hernández-Restrepo et al. 2013, Xia et al. 2014). Pseudospiropes species have comparatively smaller, ellipsoidal and distoseptate conidia (Castañeda-Ruiz et al. 2001, Ma et al. 2011a). Minimelanolocus is a wellstudied genus, which has been described from a wide range of hosts (Zhang et al. 2009, 2010, Ma et al. 2011a, b, Hernández-Restrepo et al. 2013, Xia et al. 2014). Presently, 34 species epithets are listed under Minimelanolocus (Index Fungorum 2021). The members of Minimelanolocus have a worldwide distribution, and most are saprobes on rotten leaves or dead twigs, wood and bark in aquatic habitats. In this study, Minimelanolocus rousselianus (Mont.) R.F. Castañeda \& Heredia (CBS 126086) aligned with Thysanorea papuana (Aptroot) Arzanlou et al. (CBS 212.96) with 98\% ML BS, 1.00 BY PP support in Herpotrichiellaceae (Fig. 1) based on combined LSU and ITS analysis.

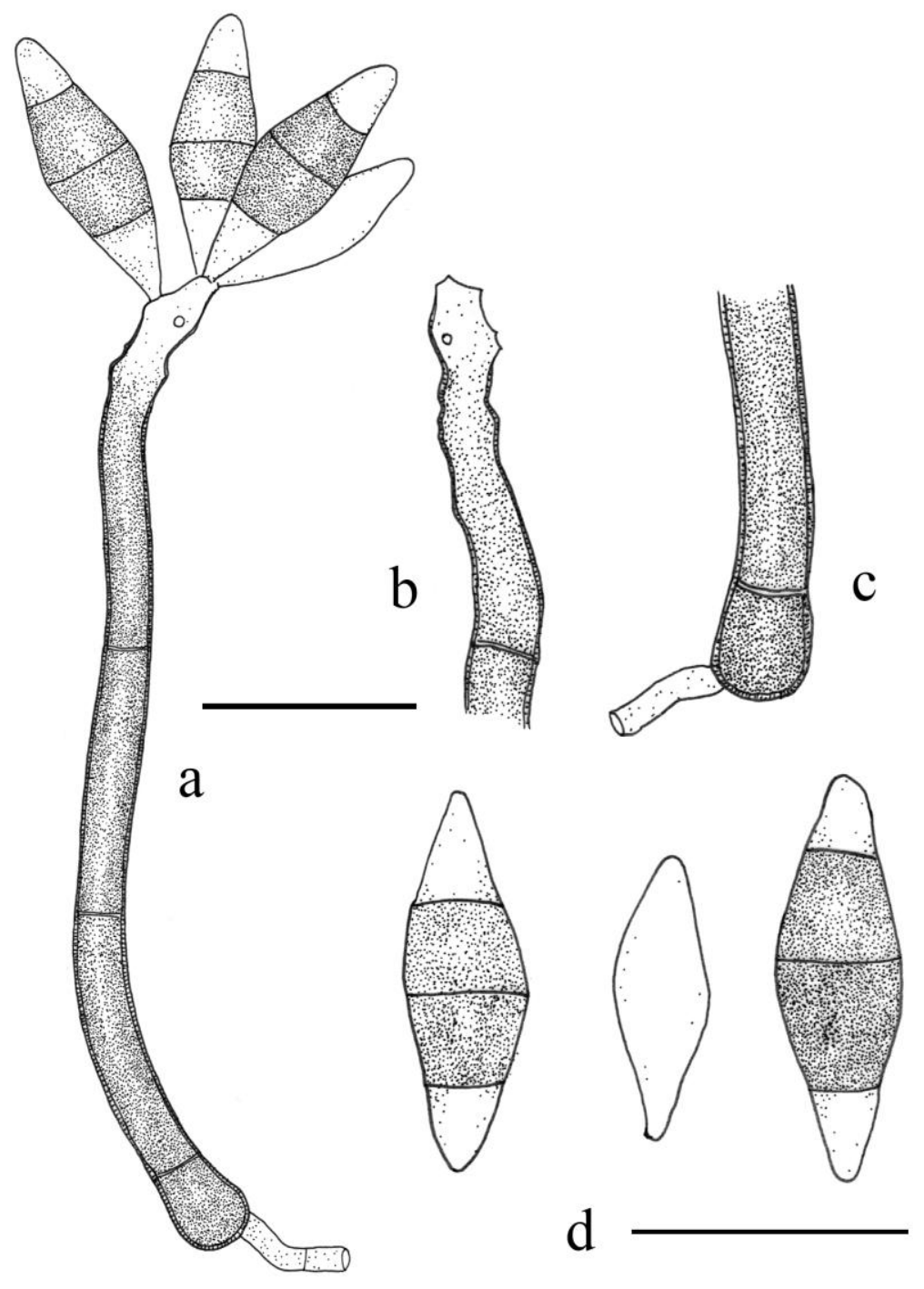

Figure 26 - Minimelanolocus navicularis (a-c redrawn from Crous et al. 2006; d redrawn from Castañeda-Ruiz et al. 2001). a Conidiophore. b Conidiogenous cells. c Base of conidiophore. $\mathrm{d}$ Conidia. Scale bar: $\mathrm{a}-\mathrm{d}=10 \mu \mathrm{m}$. 
Phialophora Medlar, Mycologia 7(4): 202 (1915)

Index Fungorum number: IF9342, Facesoffungi number: FoF 10380, 41 morphological species (Species Fungorum 2021), 20 species with molecular data.

Saprobic on decaying wood or pathogenic or animals, including humans. Mycelium superficial or partly immersed, comprising cylindrical, brown, septate hyphae in rope-like strands, tending to become moniliform, smooth-walled. Sexual morph: Capronia-like. Ascomata perithecioid, arising singly, dispersed, superficial, immersed only at the base when mature, subglobose, black, smooth-walled but with aseptate or 1-multi-septate unbranched, dark brown setae, arising from the upper part, ostiolate. Setae smooth-walled, rounded at the apex and hardly attenuated or tapering to the ends. Ostioles lateral, black, flattened. Peridium thick, composed of multi-layered, hyaline to brown cells of textura angularis. Hamathecium gelatinized, lacking pseudoparaphyses. Asci 8-spored or multispored, bitunicate, obpyriform to broadly clavate, wall apically thickened, J-. Ascospores overlapping, irregularly biseriate, oval to fusiform, muriform, hyaline to yellow-brown or grey, 1-7-trans-septate, constricted at the septa, with or without longitudinial septa, some slightly curved, smooth-walled, with or without guttules, without a gelatinous sheath or appendages. Asexual morph: hyphomycetous. Conidiophores mononematous, macronematous, unbranched, erect, hyaline to brown, straight or flexuous, cylindrical, smooth. Conidiogenous cells enteroblastic, phialidic, terminally or laterally, branched, cylindrical- elongate or occasionally flask-shaped, hyaline to brown, in a globose, gelatinous mass. Collarettes conspicuous, narrowly cylindrical to funnel-shaped or slightly flaring. Conidia acrogenous, obovoidal, clavate, ellipsoidal or fusiform, and adhere in chains, hyaline to sunhyaline, aseptate or 1-septate, sticky, smooth-walled. Conidial secession schizolytic (Medlar 1915, Schol-Schwarz 1970).

Type species - Phialophora verrucosa Medlar, Mycologia 7(4): 203 (1915)

Figs 27, 28

For synonyms see Species Fungorum

Index Fungorum number: IF214996

Type material - not indicated, from a skin lesion of Homo sapiens.

Notes - The black yeast genus Phialophora was introduced with $P$. verrucosa as the type species (Medlar 1915) which is a human skin pathogen causing chromoblastomycosis. The genus is characterized by a melanized thallus and subhyaline, obovoidal, clavate, ellipsoidal or fusiform one-celled, sticky conidia, that adhere in chains or slimy heads, that are produced through subhyaline to lightly pigmented, cylindrical- elongate or occasionally flask-shaped phialides with narrowly cylindrical to funnel-shaped or slightly flaring collarettes in a poorly differentiated conidial apparatus (Medlar 1915, Schol-Schwarz 1970). These species occur commonly as saprobes or plant pathogens on decaying wood (Untereiner \& Naveau 1999, Untereiner et al. 2008, Zhuang et al. 2010, Crous et al. 2012), and have been isolated from soil, water and food (apples, butter, margarine) (Gezuele et al. 1972, Untereiner \& Naveau 1999, Untereiner et al. 2008). Phialophora species also cause chromoblastomycosis, disseminated phaeohyphomycosis and mycetoma or other skin infections of humans (de Hoog et al. 2000a, b, Caretta et al. 2006, Untereiner et al. 2008, AlTawfiq \& Amr 2009, Feng et al. 2012, Morio et al. 2012, Li et al. 2017). Species of the sexual genus Capronia Sacc. are linked to Phialophora and several hyphomycetous asexual morphs and yeast-like synanamorphs in culture (Untereiner \& Naveau 1999, Untereiner et al. 2008, de Hoog et al. 2011, Réblová et al. 2013).

Pleomelogramma Speg., Anal. Mus. nac. B. Aires, Ser. 3 12: 389 (1909)

Index Fungorum number: IF4216, Facesoffungi number: FoF 10381, 2 morphological species (Species Fungorum 2021), molecular data unavailable.

Saprobic on decaying woody plants. Sexual morph: Ascostromata perithecioid, aggregated, dense, superficial, globose, black, smooth-walled, ostiolate. Ostiole central, black, flattened. Peridium multi-layered. Hamathecium lacking paraphyses. Asci 8-spored, bitunicate, broadly obclavate. Ascospores biseriate, fusiform, muriform, hyaline, 5-trans-septate, constricted at the septa, with or without longitudinal septa, slightly curved, smooth-walled, with or without guttules, without a gelatinous sheath or appendages. Asexual morph: Undetermined. 
Type species - Pleomelogramma argentinensis Speg., Anal. Mus. nac. B. Aires, Ser. 3 12: 389 (1909)

Index Fungorum number: IF536551

Notes - Pleomelogramma was established by Spegazzini (1909) to accommodate $P$. argentinensis which was associated with decorticated branches of Eriobotrya japonica. The genus is characterized by perithecioid, aggregated, dense ascostromata and fusiform, muriform ascospores. Petch (1924) introduced the second species P. rugosa from dead branches in Sri Lanka. Currently, two species are accepted in Pleomelogramma but neither sexual morph nor molecular sequences are available. Hence, fresh collections are needed for epitypification and the sequence data are needed to confirm the identification of Pleomelogramma in Herpotrichiellaceae.

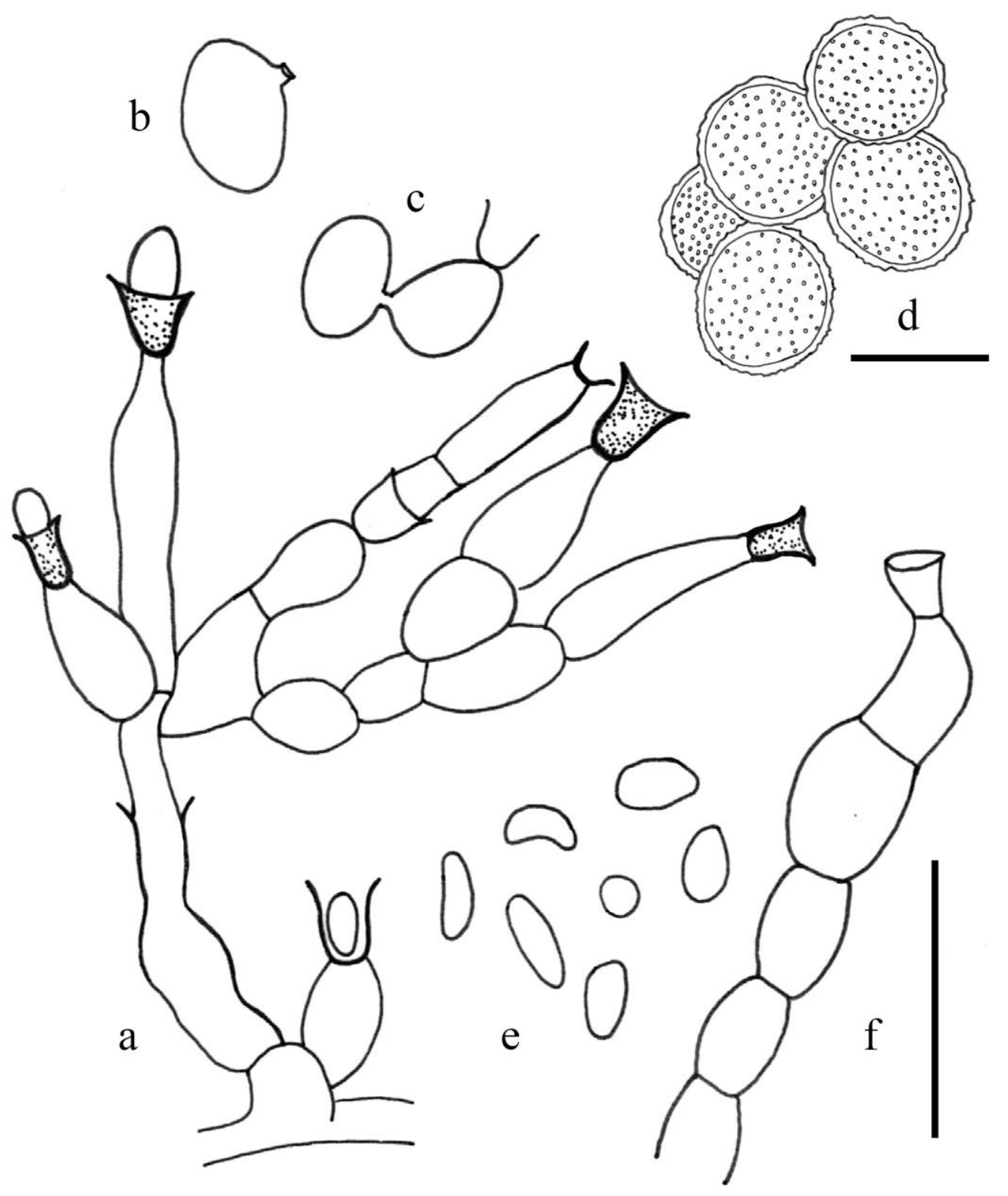

Figure 27 - Phialophora verrucosa (a, b CBS 281.35, c, e dried culture of Conant 204 (FH), d. f type material (FH), redrawn from Schol-Schwarz 1970). a Proliferating conidiophore with conidia. b Chlamydospore with muzzle-like protuberance. c Anastomosis of chlamydospores. d Chlamydospores. e Conidia. f Moniliform hypha with terminal phialide. Scale bars: $a-c, e, f=10$ $\mu \mathrm{m}, \mathrm{d}=5 \mu \mathrm{m}$. 


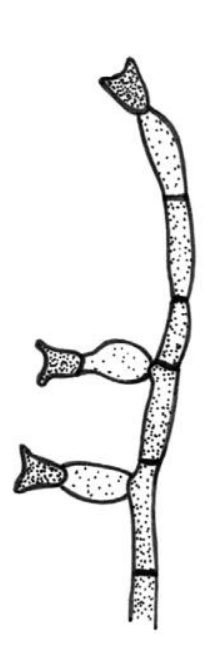

a

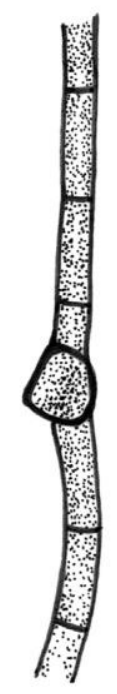

b

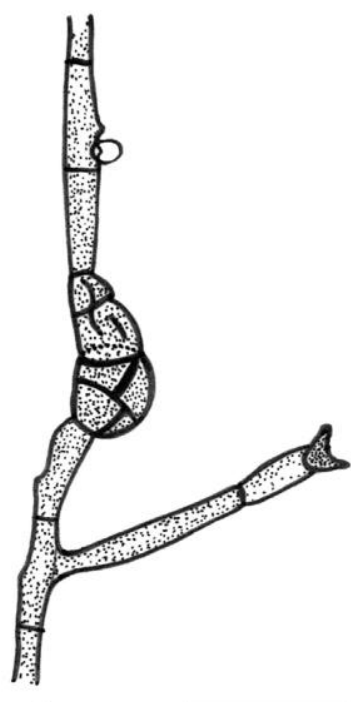

c

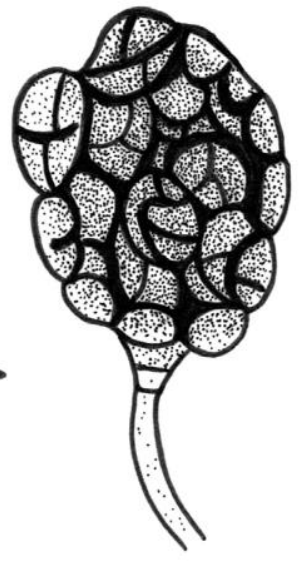

d

Figure 28 - Phialophora verrucosa (redrawn from Ajello \& Runyon 1953). a Conidiophore. b Intercalary development of "perithecial initial". c Early stage of cellular multiplication. d Multicelled terminal "perithecial" initial. Scale bars: $\mathrm{a}-\mathrm{d}=10 \mu \mathrm{m}$.

Rhinocladiella Nannf., Svensk Skogsvårdsförening Tidskr. 3-4: 461 (1934)

Index Fungorum number: IF9720, Facesoffungi number: FoF 10382, 17 morphological species (Species Fungorum 2021), 10 species with molecular data.

Saprobic, pathogenic on a variety of plants, organs of humans. Vegetative hyphae branched, pale olivaceous brown, septate, smooth-walled. Sexual morph: Undetermined. Asexual morph: hyphomycetous. Conidiophores absent or present, usually poorly differentiated from the vegetative hyphae, semimacronematous to macronematous, solitary, erect, branched or unbranched, subcylindrical, hyaline to brown, septate. Conidiogenous cells sympodial, with prominent denticles, terminal, cylindrical, pale olivaceous brown, septate. Conidia obovoid, ellipsoidal, subcylindrical to narrowly clavate, pale olivaceous to brown, aseptate, with an obtuse apex and a truncate base, with an inconspicuous conidial scar, smooth-walled. Chlamydospores absent or present. Yeast-like budding cells integrated, terminal, subcylindrical, pale brown, usually present in culture (de Hoog \& Hermanides-Nijhof 1977).

Type species - Rhinocladiella atrovirens Nannf., Svensk Skogsvårdsförening Tidskr. 3-4: 461 (1934)

Fig. 29

Index Fungorum number: IF257799

Type material - Sweden, on the wood of Pinus sp. (Pinaceae) (Holotype).

Notes - The black yeast-like genus was introduced by Melin \& Nannfeldt (1934) with Rhinocladiella atrovirens Nannf. as the type species. This genus is characterized by differentiated, sympodial conidiophores with a denticulate rachis and elongate, aseptate conidia, sometimes with exophiala-like yeasts (de Hoog \& Hermanides-Nijhof 1977). Species of Rhinocladiella are polyphyletic, and clustered with Exophiala sensu stricto and Capronia sensu stricto (Arzanlou et al. 2008, Pratibha \& Prabhugaonkar 2015). Moreover, Rhinocladiella closely resembles other members of the melanized asexual morphs of Chaetothyriales that have sympodial conidiogenesis, especially the most common etiological agents of chromoblastomycosis, such as the species in Fonsecaea, Cladophialophora and Phialophora (Badali et al. 2010, González et al. 2013, Gomes et al. 2016). 
Rhinocladiella has a rich range of ecological niches. Besides causing chromoblastomycosis, species of Rhinocladiella cause skin or organ infection, viz., $R$. aquaspersa, $R$. basitona (Badali et al. 2010, Cao et al. 2013). Members of Rhinocladiella also occur as saprobes on stems and twigs of a variety of plants, such as $R$. amoena, $R$. coryli and $R$. quercus (Hernandez-Restrepo et al. 2016, Madrid et al. 2016). Currently, members of Rhinocladiella, Exophiala, Cladophialophora and Phialophora have been reported as asexual morphs of Capronia (Untereiner \& Naveau 1999, Hernandez-Restrepo et al. 2016).

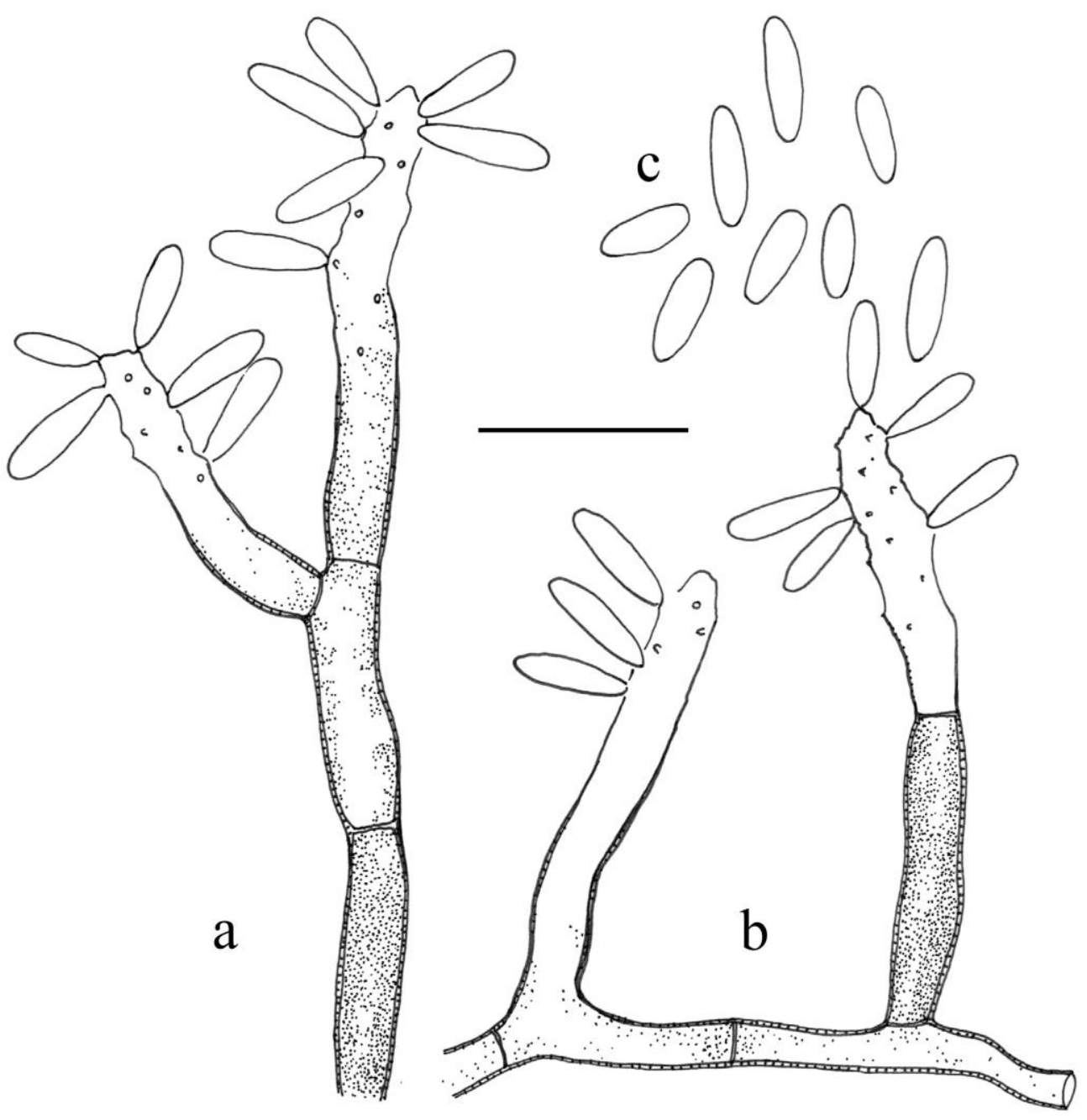

Figure 29 - Rhinocladiella atrovirens (redrawn from Seifert et al. 2011). a, b Conidiophores and conidiogenous cells with conidia. c Conidia. Scale bars: $\mathrm{a}-\mathrm{c}=10 \mu \mathrm{m}$.

Sorocybe Fr., Summa veg. Scand., Sectio Post. (Stockholm): 468 (1849)

Index Fungorum number: IF9958, Facesoffungi number: FoF 10383, 3 morphological species (Species Fungorum 2021), 2 species with molecular data.

Saprobic on the resin of plant hosts. Hyphae of stipe infrequently branched, brown to dark brown, septate. Sexual morph: Undetermined. Asexual morph: Synnemata scattered or gregarious, dark brown to black, often splayed at the base but with a compact cylindrical stipe, and a compact, dry, ellipsoidal conidial head. Conidiophores mononematous or synnematous and arising from dark brown subiculum. Conidiogenous cells terminal or in pairs at the ends of the stipe hyphae, cylindrical with a truncate base. Conidia in sparingly branched acropetal chains, oblong-ellipsoidal, fusiform, brown, aseptate, rarely septate, secession scars available, smooth-walled, sometimes 
adjacent conidia anastomosing, ramoconidia infrequent, usually with just two emerging chains, conidial chains appressed and more or less parallel (Crous et al. 2019a).

Type species - Sorocybe resinae (Fr.) Fr., Summa veg. Scand., Sectio Post. (Stockholm): 468 (1849)

Index Fungorum number: IF119429

Fig. 30

Type material - Not indicated. In resin of Pinus sp. (Pinaceae).

Notes - Sorocybe Fr. was introduced by Fries (1849) and it is characterized by conspicuous synnemata, a less conspicuous mononematous morph, fusiform, brown, aseptate conidia and ramoconidia with two emerging chains (Fries 1849, Crous et al. 2019a). All collections of $S$. resinae are restricted to conifer resin. Pratibha et al. (2005) introduced $S$. indica Gawas et al. with white, terminally olivaceous to median brown synnemata and hyaline [what], but the fusiform, slimy conidia do not fit the genus description as now circumscribed. Seifert et al. (2007) showed the type species of Sorocybe, S. resinae was related to Capronia and allied asexual genera based on LSU analysis, thus, $S$. resinae was suggested to be placed in Herpotrichiellaceae. However, Crous et al. (2019a) and our study indicate that the reference sequences of S. resinae and S. oblongispora are aligned with Verrucariaceae, Verrucariales based on combined ITS and LSU sequences analysis. Therefore, we maintain Sorocybe in Herpotrichiellaceae pending further investigation.

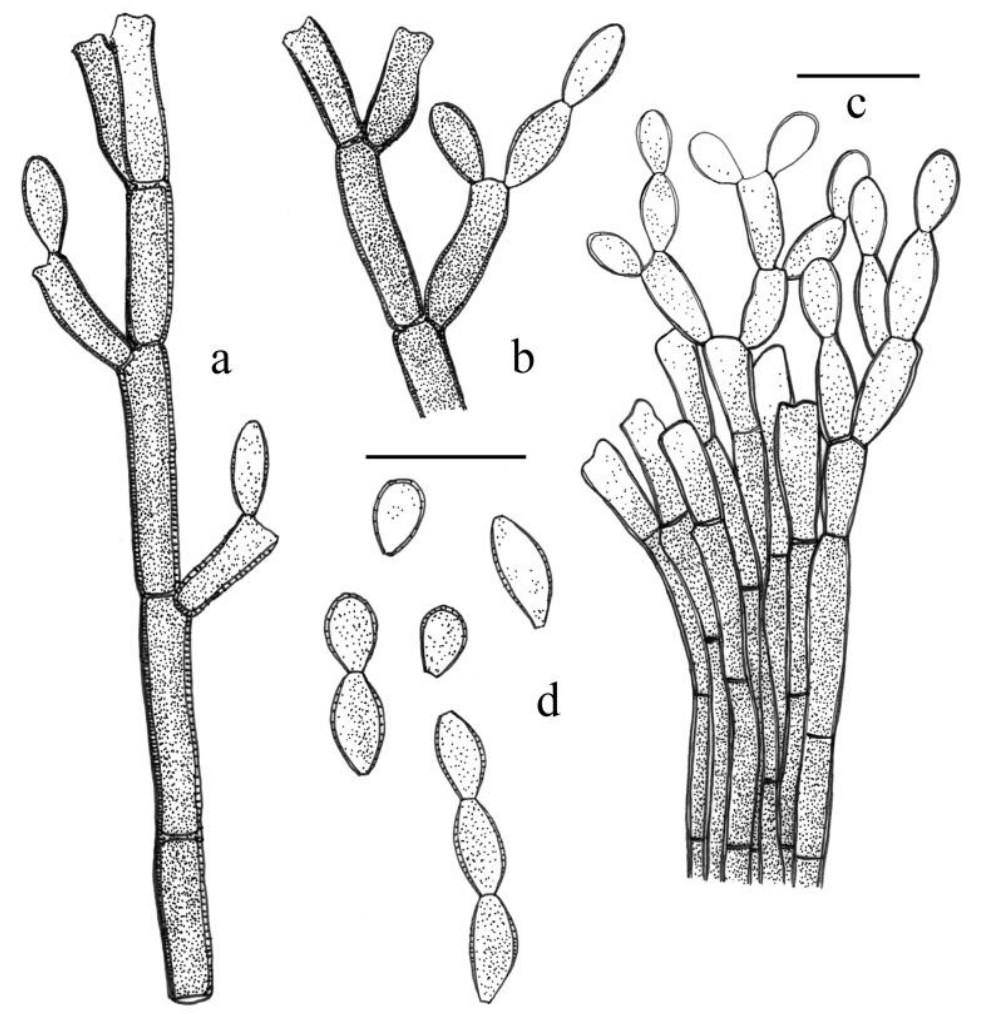

Figure 30 - Sorocybe resinae (redrawn from Seifert et al. 2011). a-c Conidiophores and conidiogenous cells with conidia. $d$ Acropetally developing chains of conidia. Scale bars: $a-d=10$ $\mu \mathrm{m}$.

Thysanorea Arzanlou, W. Gams \& Crous, Stud. Mycol. 58: 80 (2007)

Index Fungorum number: IF504555, Facesoffungi number: FoF 10384, 14 morphological species (Species Fungorum 2021), 7 species with molecular data.

Saprobic on submerged wood or dead woody plant. Mycelium immersed, comprising septate, pale brown, smooth-walled hyphae. Sexual morph: Undetermined. Sexual morph: hyphomycetous. 
Conidiophores micronematous, macronematous, erect, simple or apically branched, sometimes proliferating percurrently in the apex, cylindrical, dark brown, septate, slightly constricted at septa, smooth-walled. Conidiogenous cells sympodial, terminal or intercalary, polyblastic, cylindrical, clavate to doliiform, hyaline towards the apex, brown at the base, with crowded conidiogenous loci inconspicuous to slightly prominent, refractive to somewhat obscure, more or less prominent denticles. Conidia acropleurogenous, oblong, obovoid, cylindrical, broadly fusiform to subpyriform, pale brown, rounded at apex, attenuate and narrowly truncate at base, brown, 0-3septate, constricted at septa, smooth-walled, guttulate. conidial secession schizolytic. Synasexual morph: hyphomycetous. Conidiophores simple, erect, brown, smooth-walled. Conidiogenous cells terminal, discrete, phialidic, subglobose to lageniform, with a balloon- to funnel-shaped collarette, brown, often in clusters at the apex of the conidiophores. Conidia solitary, subglobose to obovate, unicellular, hyaline, guttulate, smooth-walled. (Dong et al. 2018, Wang et al. 2019, HernándezRestrepo et al. 2020).

Type species - Thysanorea papuana (Aptroot) Arzanlou, W. Gams \& Crous, Stud. Mycol. 58: 80 (2007)

三Periconiella papuana Aptroot, Nova Hedwigia 67(3-4): 491 (1998)

Fig. 31

Index Fungorum number: IF504556

Type material - Papua New Guinea, on petiole of leaf, Aptroot 36647 (CBS, holotype).

Notes - Arzanlou et al. (2007) introduced Thysanorea Arzanlou et al. with T. papuana (Aptroot) Arzanlou et al. as the type species. Thysanorea papuana is similar to Periconiella Sacc. species based on the branched conidiophores, but phylogenetically segregates from Periconiella. Thysanorea is characterized by dimorphic conidiophores, denticle-like conidiogenous loci and pale brown, obovoid to pyriform, mostly 3-septate conidia (Arzanlou et al. 2007). Hernández-Restrepo et al. (2020) revised the generic description and included species with phialidic synasexual morphs. Based on the morphological differences and phylogenetic analysis, 12 new combinations from Minimelanolocus R.F. Castañeda \& Heredia fit the new concept of delimitation of Thysanorea, therefore 14 species are accepted in Thysanorea.

Uncispora R.C. Sinclair \& Morgan-Jones, Mycotaxon 8(1): 140 (1979)

Index Fungorum number: IF10352, Facesoffungi number: FoF 10385, 4 morphological species (Species Fungorum 2021), 2 species with molecular data.

Saprobic on dead twigs of various plants in terrestrial habitats. Colonies broadly effuse, hairy, pale brown to brown. Mycelium immersed to superficial, composed of branched, hyaline to pale brown, septate, smooth-walled hyphae. Sexual morph: Undetermined. Asexual morph: hyphomycetous. Conidiophores macronematous, synnematous or - fasciculate, simple or branched, erect, cylindrical, brown, septate, straight or flexuous, smooth-walled, thick-walled. Conidiogenous cells integrated, terminal, determinate, monoblastic, cylindrical, brown, smooth-walled. Conidia solitary, acrogenous, obclavate, hooked towards the apex, truncate at the base, subhyaline to pale brown, septate, straight or curved, smooth-walled or verrucose-walled at maturity (Sinclair \& Morgan-Jones 1979).

Type species - Uncispora harroldiae R.C. Sinclair \& Morgan-Jones [as 'harroldii'], Mycotaxon 8(1): 142 (1979)

Fig. 32

Index Fungorum number: IF325266

Type material - USA, Alabama, on dead twigs of Picea nigra (Du Roi) Link (Pinaceae), 15 May 1978, Harrold (AUA, holotype).

Notes - Sinclair \& Morgan-Jones (1979) introduced Uncispora R.C. Sinclair \& MorganJones with $U$. harroldiae R.C. Sinclair \& Morgan-Jones as the type species. The genus is characterized by macronematous, synnematous or fasciculate, brown conidiophores, and subhyaline to pale brown, obclavate conidia with a hooked apex. Uncispora is similar to Sporidesmium Link (Ellis 1971) in its holoblastic, monoblastic, integrated, non-cicatrized conidiogenous cells and broadly truncate conidia, but differs by its occasionally branched and synnematous conidiophores 
and its unique conidia with curved or hooked terminal cells. Uncispora formed a sister clade with Minimelanolocus rousselianus (Mont.) R.F. Castañeda \& Heredia and Thysanorea papuana (Aptroot) Arzanlou, W. Gams \& Crous and clustered in Herpotrichiellaceae with 73\% ML BS and 1.00 BY PP bootstrap support (Fig. 1).

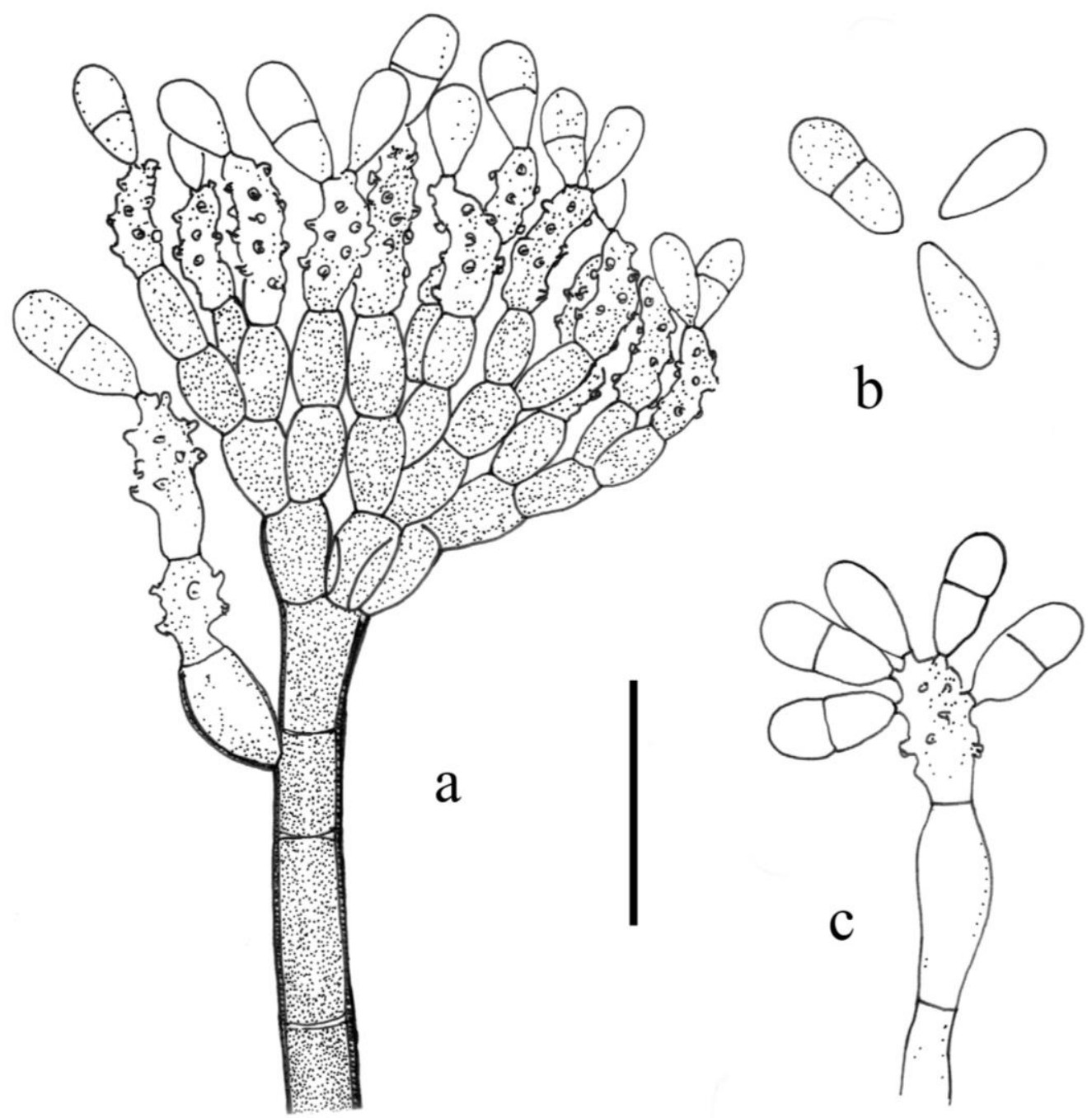

Figure 31 - Thysanorea papuana (CBS 212.96, redrawn from Arzanlou et al. 2007). a, $b$ Conidiophores and conidiogenous cells with conidia. $\mathrm{b}$ Conidia. Scale bars: $\mathrm{a}-\mathrm{c}=10 \mu \mathrm{m}$.

Veronaea Cif. \& Montemart., Atti Ist. bot. Univ. Lab. crittog. Pavia, sér. 5 15: 68 (1957)

Index Fungorum number: IF10387, Facesoffungi number: FoF 10386, 19 morphological species (Species Fungorum 2021), 4 species with molecular data.

Biotrophic or saprobic on various plants, animal dung and soil. Colonies effuse, velvety, pale olivaceous-brown. Hyphae immersed, hyaline to pale olivaceous, darkly pigmented in aerial hyphae, smooth-walled. Sexual morph: Undetermined. Asexual morph: hyphomycetous. Conidiophores erect, straight or flexuose, unbranched or occasionally loosely branched, sometimes geniculate, pale to medium- or olivaceous-brown, smooth-walled. Conidiogenous cells terminally integrated, occasionally intercalary, polyblastic, cylindrical, hyaline to pale brown, rachis with crowded, flat to slightly prominent, faintly pigmented, unthickened scars, smooth-walled. Conidia solitary cylindrical to pyriform, rounded at the apex and truncate at the base, subhyaline to pale brown, 1(-2)-septate, conidial secession schizolytic. Exophiala-type budding cells absent in culture (Arzanlou et al. 2007). 
Type species - Veronaea botryosa Cif. \& Montemart., Atti Ist. bot. Univ. Lab. crittog. Pavia, sér. 5 15: 68 (1957)

Index Fungorum number: IF307734

Fig. 33

Type material - Italy, from olive slag (holotype).

Notes - Ciferri \& Montemartini (1957) established Veronaea Cif. \& Montemart. with $V$. botryosa Cif. \& Montemart. as the type species. The genus is characterized by rachides with straight, slightly geniculate conidiophores, flat, barely prominent, unthickened, slightly darkened conidiogenous cells and cylindrical to pyriform, 1(-2)-septate conidia. Veronaea resembles Rhinocladiella Nannf., but can be distinguished by the absence of exophiala-like budding cells, flat, barely prominent conidiogenous cells and predominantly 1-septate conidia. Phylogenetically, Veronaea botryosa resides in Herpotrichiellaceae (Fig. 1).

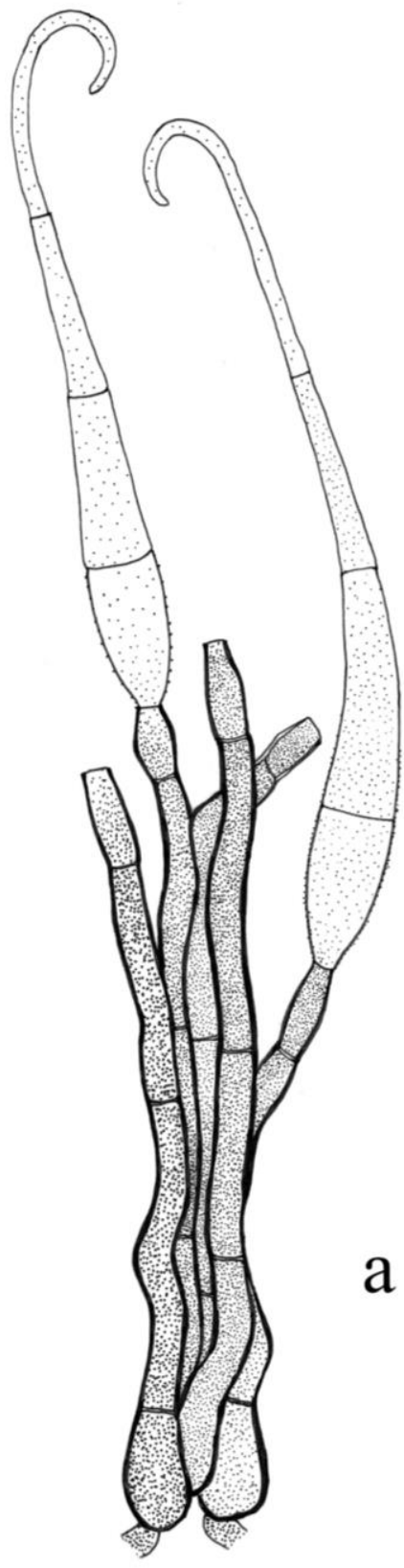

$\mathrm{b}$

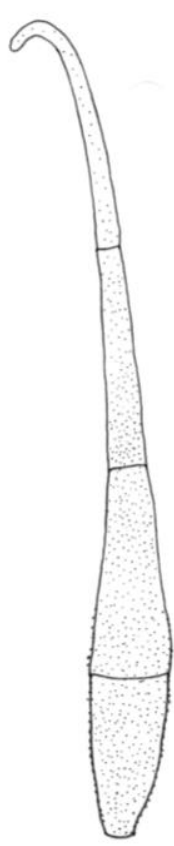

a

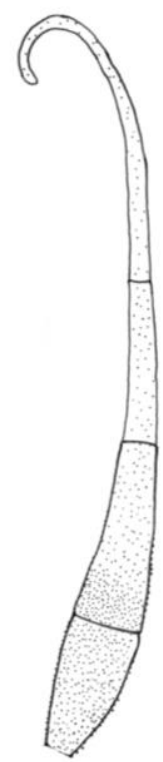

Figure 32 - Uncispora harroldiae (YMF 1.04038, holotype, redrawn from Sinclair \& MorganJones 1979). a Conidiophores and Conidiogenous cells with conidia. b Conidia. Scale bars: a, b = $10 \mu \mathrm{m}$. 

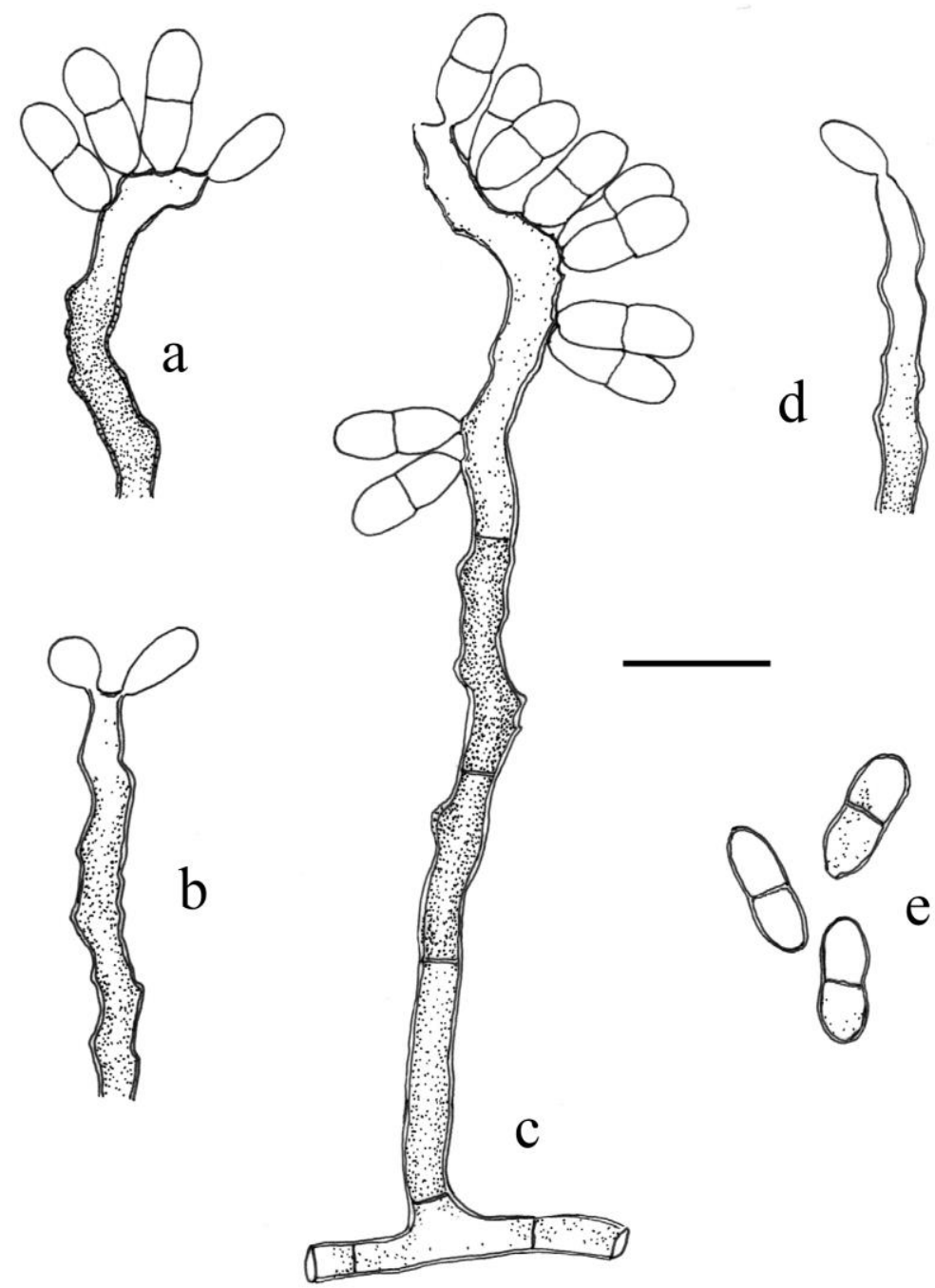

Figure 33 - Veronaea botryosa (redrawn from Seifert et al. 2011). a-d Conidiophores and Conidiogenous cells with conidia. e Conidia. Scale bars: $\mathrm{a}-\mathrm{e}=10 \mu \mathrm{m}$.

\section{Ecological and economic significance of Herpotrichiellaceae}

Herpotrichiellaceae is a species-rich family with a worldwide distribution occupying diverse ecological habitats, such as being ant-associated, epilithic, epiphytic, human and animal pathogens causing infections of the blood, organs and skin, soil inhabiting, environmental and saprobes of plant material (Untereiner et al. 1995, Prenafeta-Boldú et al. 2001, Matos et al. 2002, Ruibal et al. 2008, Sudhadham et al. 2008, de Hoog et al. 2011, Isola et al. 2013, Vicente et al. 2014, Raghupathi et al. 2018, Quan et al. 2020).

Lyrommataceae Lücking, Fl. Neotrop., Monogr. 103: 184 (2008)

Index Fungorum number: IF538320; Facesoffungi number: FoF 10387

Thallus foliicolous, crustose. Photobiont trentepohlioid. Sexual morph: Ascomata perithecioid, globose to shortly barrel-shaped, sessile, setose. Excipulum thin-walled, composed of several layers of dark brown, irregular hyphae. Involucrellum absent. Hamathecium comprising unbranched paraphyses in young ascomata, but in mature ascomata often aparaphysate, I-, KI-. Asci 8-spored, fissitunicate, obclavate to saccate, I-, Kl-. Ascospores hyaline, septate. Asexual morph: Conidiomata pycnidia, sessile, elongate, barrel-shaped to ellipsoid, setose or glabrous. Wall of conidiomata comprising a thin layer of distinctly parallel hyphae, dark brown. Conidiophores filamentous, unbranched, septate. Conidiogeneous cells acropleurogenous, holoblastic, with the 
lateral formation of conidia. Conidia filiform, hyaline, aseptate (Lücking 2008).

Type - Lyromma Bat. \& H. Maia

Notes - Lyrommataceae Lücking, contains a single genus Lyromma Bat. \& H. Maia and has ascomata with antler-shaped appendages and sessile, setose pycnidia with filiform conidia (Lücking 2008, Flakus \& Farkas 2013). Lücking (2008) classified the lichenized Lyrommataceae in Chaetothyriales based on the close relationship among Chaetothyriales, Verrucariales Mattick ex D. Hawksw. \& O.E. Erikss. and Pyrenulales Fink ex D. Hawksw. \& O.E. Erikss. which appear on a clade with the bulk of the lichenized Discomycetes (Ostropales, Lecanorales) as a sister group and distant from the Dothideales (Lutzoni et al. 2001, 2004, Eriksson et al. 2004, Del Prado et al. 2006). However, no sequence data of any species of Lyrommataceae are available, thus we tentatively accept these opinions and retain Lyrommataceae in Chaetothyriales pending further studies.

Lyromma Bat. \& H. Maia, Atas Inst. Micol. Univ. Pernambuco 2: 359 (1965)

Index Fungorum number: IF88008, morphological species (Species Fungorum 2021), molecular data unavailable.

Description - see Lücking (2008).

Type species - Lyromma nectandrae Bat. \& H. Maia, Atas Inst. Micol. Univ. Recife 2: 360 (1965)

Index Fungorum number: IF345286

Fig. 34

Type material - Pernambuco, on leaves of Nectrandra sp. (Lauraceae) (URM 18764, holotype; URM 69375, epitype).
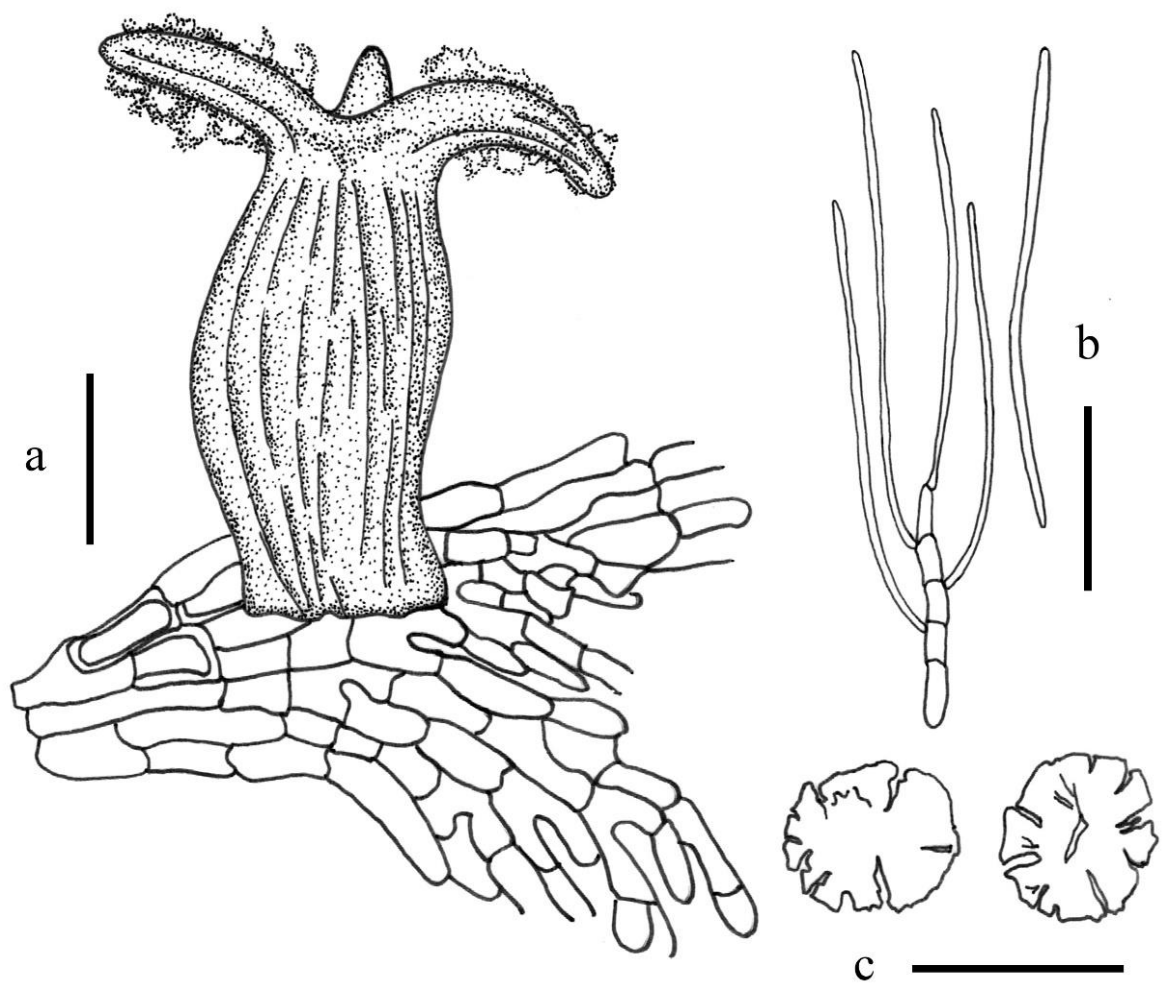

Figure 34 - Lyromma nectandrae (URM 18764, holotype, redrawn from Batista \& Silva Maia 1965). a Pycnidium. b Conidia. $\mathrm{c}$ Base crystals conidia. Scale bars: $\mathrm{a}=50 \mu \mathrm{m}, \mathrm{b}, \mathrm{c}=20 \mu \mathrm{m}$.

Microtheliopsidaceae O.E. Erikss., Op. bot. Soc. bot. Lund 60: 97 (1981)

Index Fungorum number: IF81007; Facesoffungi number: FoF 10388

Thallus foliicolous, crustose. Photobiont trentepohlioid. Sexual morph: Ascomata perithecioid, scattered or aggregated, lens-shaped to conical with rounded to radiantly elongate 
base. Excipulum thin-walled, composed of layers of dark brown, irregular, intricate, wavy hyphae. Involucrellum formed by algal cells surrounded by dark brown hyphae. Hamathecium aparaphysate, J+, KI+. Asci 8-spored, fissitunicate, obclavate, J-, Kl-. Ascospores submuriform hyaline to greyish brown, septate. Asexual morph: Undetermined.

Type-Microtheliopsis Müll. Arg.

Notes - Microtheliopsidaceae O.E. Erikss. was introduced with the type genus Microtheliopsis Müll. Arg. by Eriksson (1981). Microtheliopsidaceae is characterized by perithecioid ascomata without paraphyses, fissitunicate asci, and greyish brown ascospores. Eriksson (1981) considered the Microtheliopsidaceae to be close to Herpotrichiellaceae in Chaetothyriales (Eriksson et al. 2004, Eriksson 2006, Lücking 2008). Currently, the family contains Microtheliopsis, which is foliicolous lichen communities.

Microtheliopsis Müll. Arg., Flora, Regensburg 73: 195 (1890)

Index Fungorum number: IF3200, 4 morphological species (Species Fungorum 2021), molecular data unavailable.

Type species - Microtheliopsis uleana Müll. Arg., Flora, Regensburg 73: 195 (1890)

Index Fungorum number: IF395632; Facesoffungi number: FoF 04616

Thallus crustose, continuous or dispersed into rounded to irregular patches, smooth or rarely thinly setose, ochraceous yellow to yellowish brown or green. Setae formed by single, unbranched, dark brown, septate hyphae. Photobiont cells rectangular, setose, pale zoosporangia and gametangia. Sexual morph: Ascomata $0.12-0.2 \mathrm{~mm}$ diam., perithecioid, scattered or aggregated, lens-shaped to conical, dark brown, smooth-walled, ostiolate. Ostiole indistinct. Excipulum 7-12 $\mu \mathrm{m}$ thick, paraplectenchymatous, inner part multi-layered, composed of narrow, thin-walled and periclinally elongate, almost hyaline cells, outermost part composed of irregular, thin-walled, dark brown cells. Involucrellum 5-10 $\mu \mathrm{m}$ thick, dark brown. Hamathecium lacking paraphyses, gel J+, very faintly bluish, KI+, faintly bluish. Asci $18-34 \times 6-9 \mu \mathrm{m}(\overline{\mathrm{x}}=25 \times 8 \mu \mathrm{m}, \mathrm{n}=10)$, fissitunicate, broadly clavate to saccate, J-, KI-, but lumen I+ yellow and KI+ pale yellow (colour of iodine itself). Ascospores $9-15 \times 2-5 \mu \mathrm{m}(\overline{\mathrm{x}}=12 \times 3.6 \mu \mathrm{m}, \mathrm{n}=10)$ 8-spored, overlapping 2-seriate, ellipsoid to fusiform, tapering towards both ends, pale to dark grayish brown, 3-septate, not constricted or slightly constricted at the septa, thin-walled, without a gelatinous sheath. Asexual morph: Undetermined.

Material examined - Costa Rica, Puntarenas Province, Reserva Biológica Carara, c.15 km SSW of Orotina, Alt. m. $50 \mathrm{~m}, 84^{\circ} 37^{\prime} \mathrm{W}, 9^{\circ} 47^{\prime} \mathrm{N}$, Disturbed primary, c. $40 \mathrm{~m}$ tall forest, along trail near warden's house, on leaves of unidentified plant, foliicolous in undergrowth, 20 November 1988, H. Sipman \& P. Döbbeler (B 60 0178769).

Paracladophialophoraceae Crous, Persoonia 40: 373 (2018)

Index Fungorum number: IF825430; Facesoffungi number: FoF 10389

Pathogenic on leaves in terrestrial habitats. Mycelium comprising branched, pale brown, septate, smooth-walled hyphae. Sexual morph: Undetermined. Asexual morph: hyphomycetous. Conidiophores reduced to conidiogenous cells or macronematous, solitary, erect, grey-brown, straight or curved, septate, apical apparatus tuft-like due to extremely long conidial chains. Conidiogenous cells terminal and lateral, mono- and polyblastic, proliferating sympodially, subcylindrical, pale brown, smooth-walled. Conidia ellipsoid to fusoid-ellipsoid, subcylindrical, aseptate, pale brown, smooth-walled, guttulate, in long branched chains, ramoconidia subcylindrical, septate (Crous et al. 2016).

\section{Type-Paracladophialophora Crous}

Notes - Paracladophialophoraceae Crous was established to accommodate Paracladophialophora Crous with two species isolated from living leaves (Crous et al. 2016, 2018). Based on phylogenetic analyses, Paracladophialophoraceae formed a distinct clade sister to Cyphellophoraceae in Chaetothyriales, while species in Cyphellophoraceae are recognized by solitary conidia arising from phialides and aggregating in a mucoid droplet. 
Paracladophialophora Crous, Persoonia 37: 299 (2016)

Index Fungorum number: IF819058, Facesoffungi number: FoF 10390, 2 morphological species (Species Fungorum 2021), 2 species with molecular data.

Pathogenic on leaves. Mycelium comprising branched, pale brown, septate, smooth-walled hyphae. Sexual morph: Undetermined. Asexual morph: hyphomycetous. Conidiophores macronematous, solitary, erect, grey- brown, straight or curved, septate, apical apparatus tuft-like due to extremely long conidial chains. Conidiogenous cells terminal and lateral, mono- and polyblastic, proliferating sympodially, subcylindrical, pale brown, smooth-walled. Conidia ellipsoid to fusoid-ellipsoid, aseptate, pale brown, smooth-walled, guttulate, in long branched chains, ramoconidia subcylindrical, septate.

Type species - Paracladophialophora carceris Crous \& Roets, Persoonia 37: 299 (2016)

Index Fungorum number: IF819059

Fig. 35

Type material - South Africa, Robben Island, prison courtyard, on leaves of Aloe sp. (Asphodelaceae), 23 May 2015, P.W. Crous (CBS H-22865, holotype; CPC 27596 = CBS 142068, extype).

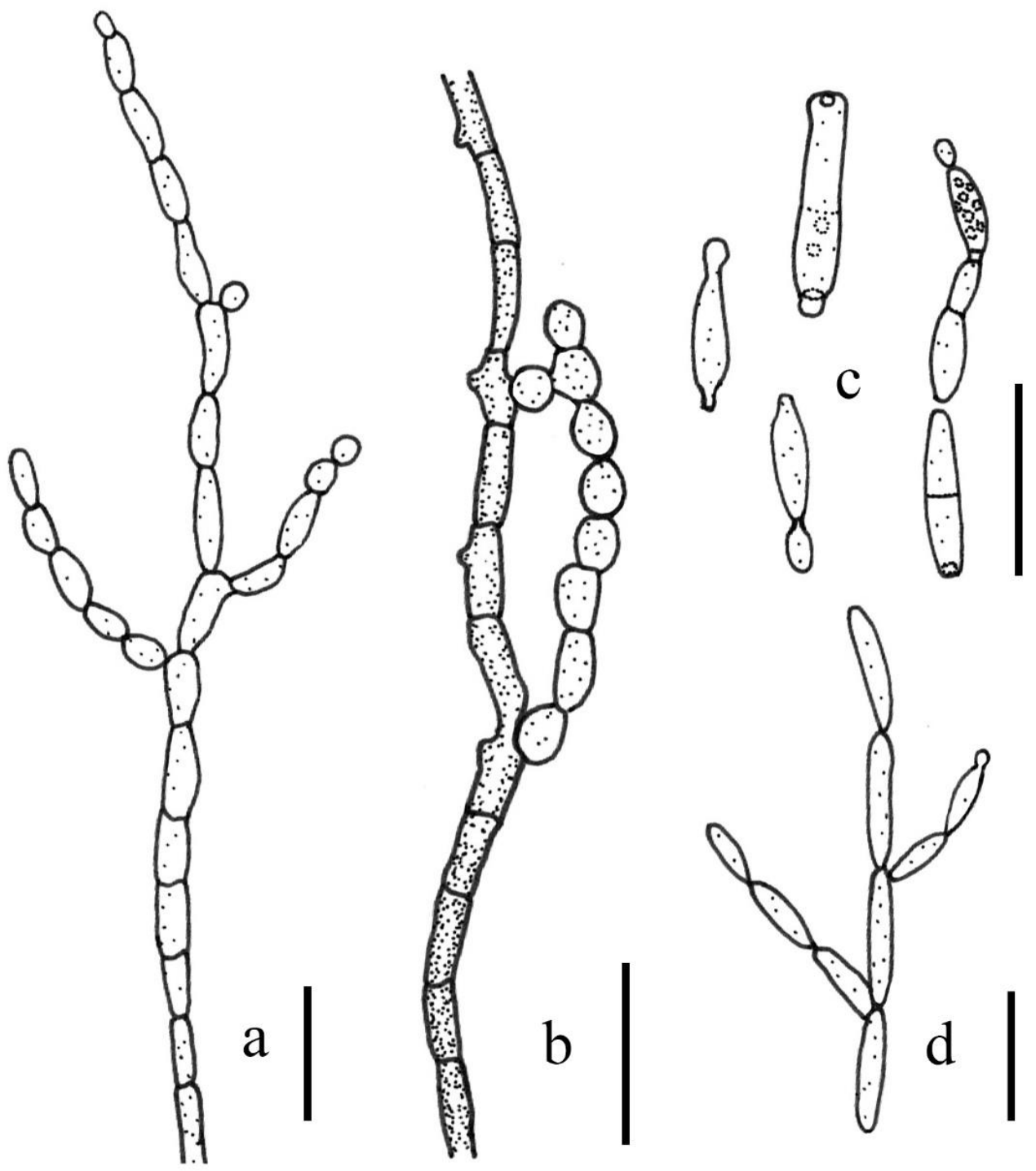

Figure 35 - Paracladophialophora carceris (CBS 142068, ex-type, redrawn from Crous et al. 2016). a, b, d Conidiophores. c Conidia and ramoconidia. Scale bars: $a-d=10 \mu \mathrm{m}$. 
Notes - Paracladophialophora Crous was introduced by Crous et al. (2016) with the yeastlike species $P$. carceris Crous \& Roets, isolated from the living leaves of Aloe sp. (Asphodelaceae). This genus is characterized by mono- and polyblastic, subcylindrical conidiogenous cells and ellipsoid to fusoid-ellipsoid, aseptate conidia in long branched chains (Crous et al. (2016). Paracladophialophora resembles Cladophialophora, because some Cladophialophora species have also been found associated with living plants (Crous et al. 2007, 2013, de Hoog et al. 2007, Badali et al. 2011, Park \& Shin 2011, Feng et al. 2014), while Cladophialophora has flask-shaped or funnelshaped phialides, collarettes occasionally present, and hyaline, subspherical, aseptate phialoconidia. Phylogenetically, Paracladophialophora constitutes a distinct clade in Chaethytiales.

\section{Pyrenotrichaceae Zahlbr., (1926)}

Index Fungorum number: IF92179; Facesoffungi number: FoF 10391

Thallus corticolous or foliicolous, composed of densely arranged, but not conglutinated, appressed filaments, filaments formed by unbranched or falsely branched photobiont threads wrapped in a sheath of fungal hyphae, hyphae branched and anastomosing, formed by elongate, often strongly curved and terminally inflated, pale brownish cells. Photobiont cyanobacterial. Sexual morph: Ascomata perithecioid, sessile or immersed between thallus filaments, globose to pear-shaped with a short neck, glabrous. Ostiole indistinct, with rather long, hyaline periphysoids. Excipulum thin, paraplectenchymatous, composed several layers of narrow to broader, thin-walled to thick-walled and hyaline to strongly pigmented cells. Involucrellum absent. Hamathecium aparaphysate, J+, KI+. Asci fissitunicate, broadly clavate to saccate, J-, KI-, but lumen I+ yellow and KI+ pale yellow. Ascospores 8-spored, transversally septate to muriform, pale to dark grayish brown. Asexual morph: Undetermined.

Type-Pyrenothrix Riddle

Notes - Engler \& Prantl (1926) established Pyrenotrichaceae Zahlbr. to accommodate Pyrenothrix Riddle with two foliicolous species presently accepted (Riddle 1917, Herrera-Campos et al. 2005). Henssen (1964) referred Pyrenothrix to Pleosporales because it has perithecia. Eriksson (1981) contradicted Henssen's placement for this genus and suggested Pyrenothrix was closely related to the sooty molds, in particular Coccodiniaceae, now placed in Chaetothyriales by filamentous thallus and perithecia. Herrera-Campos et al. (2005) proposed including the genus in Chaetothyriales. Molecular sequences for species of Pyrenotrichaceae are lacking, and therefore we place this family in Chaetothyriales, consistent with the opinion of Herrera-Campos et al. (2005), Lücking (2008) and Wijayawardene et al. (2020), pending further study.

Pyrenothrix Riddle, Bot. Gaz. 64: 513 (1917)

= Lichenothrix Henssen, Ber. dt. bot. Ges. 77: 318 (1964)

Index Fungorum number: IF4608, 2 morphological species (Species Fungorum 2021), molecular data unavailable.

Type species - Pyrenothrix nigra Riddle, Bot. Gaz. 64: 513 (1917)

Figu. 36

For synonyms see Species Fungorum

Index Fungorum number: IF153614; Facesoffungi number: FoF 10392

Thallus corticolous or foliicolous, composed of densely arranged, but not conglutinated, appressed filaments, filaments formed by unbranched or falsely branched photobiont threads wrapped in a sheath of fungal hyphae, hyphae branched and anastomosing, formed by elongate, often strongly curved and terminally inflated, pale brownish cells. Photobiont cyanobacterial. Sexual morph: Ascomata 12-15 mm diam., perithecioid, sessile or immersed between thallus filaments, globose to pear-shaped with a short neck, glabrous. Ostiole indistinct, with rather long, hyaline periphysoids. Excipulum 22-35 $\mu \mathrm{m}$ wide, thin, paraplectenchymatous, composed several layers of narrow to broader, thin-walled to thick-walled and hyaline to strongly pigmented cells. Involucrellum absent. Hamathecium aparaphysate (but empty asci resembling paraphyses often present), gel I+ very faintly bluish, KI+ faintly bluish. Asci 40-55 $\times 15-25 \mu \mathrm{m}(\overline{\mathrm{x}}=48 \times 20 \mu \mathrm{m}, \mathrm{n}=$ 10), 8-spored, fissitunicate, broadly clavate to saccate, J-, KI-, but lumen I+ yellow and KI+ pale 
yellow (colour of iodine itself). Ascospores 25-34 $\times 10-12 \mu \mathrm{m}(\overline{\mathrm{x}}=25 \times 8 \mu \mathrm{m}, \mathrm{n}=10)$, uni- or biseriate, broadly fusiform, tapering towards both ends, pale to dark grayish brown, transversally septate to muriform, constricted at the septa, thin-walled, without a gelatinous sheath. Asexual morph: Undetermined.

Material examined - USA, Florida, West Palm Beach, on bark of scrub oaks, December 1897, R. Thaxter (FH00259851, holotype).
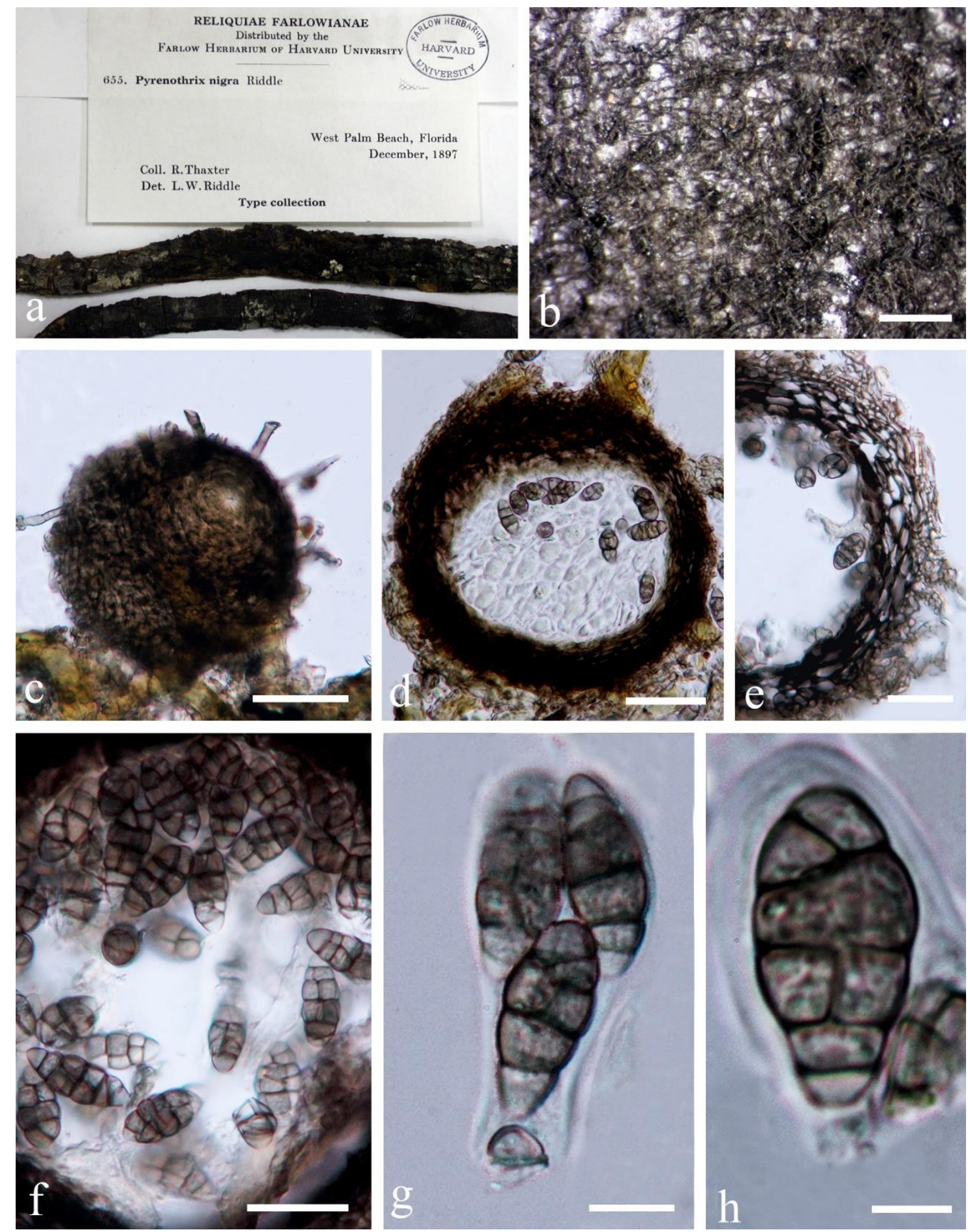

Figure 36 - Pyrenothrix nigra (FH00259851, holotype). a Envelop, collection information and herbarium material of Pyrenothrix nigra. b Appressed filamentous thallus with perithecia. c Squash mount of ascoma. d Vertical section through ascoma. e Vertical section through ascoma wall. f Ascospores. g, h Asci with ascospores. Scale bars: $b=500 \mu \mathrm{m}, \mathrm{c}, \mathrm{d}=50 \mu \mathrm{m}, \mathrm{e}, \mathrm{f}=25 \mu \mathrm{m} \mathrm{g}=10$ $\mu \mathrm{m}, \mathrm{h}=5 \mu \mathrm{m}$. 


\section{Other genera included:}

Neophaeococcomyces Crous \& M.J. Wingf., Persoonia 35: 287 (2015)

Index Fungorum number: IF814935; Facesoffungi number: FoF 10393; 4 morphological species (Species Fungorum 2021), with molecular data.

Saprobic on dead bark of plants in terrestrial habitats. Colonies lacking mycelium but comprising a globular mass of chlamydospore-like cells. Sexual morph: Undetermined. Asexual morph: hyphomycetous. Chlamydospore-like cells globose, hyaline to brown, covered in mucus, aseptate, thin-walled, remaining attached to one another, through younger end cells at the colony margin. Conidia ellipsoid to globose, hyaline, thin-walled, covered in mucus, smooth-walled (Crous et al. 2015a).

Type species - Neophaeococcomyces aloes (Crous \& M.J. Wingf.) Crous \& M.J. Wingf., Persoonia 35: 287 (2015)

$\equiv$ Phaeococcomyces aloes Crous \& M.J. Wingf., Persoonia 31: 237 (2013)

Fig. 37

Index Fungorum number: IF814936, 2 morphological species (Species Fungorum 2021) with molecular data.

Type Material - South Africa, Western Cape Province, Clanwilliam, on dark lesions on dead bark of Aloe dichotoma Masson (Xanthorrhoeaceae), September 2012, M.J. Wingfield (CBS H21441, holotype; CPC 21873 = CBS 136431, ex-type).

Notes - Neophaeococcomyces Crous \& M.J. Wingf. was introduced by Crous et al. (2015a) with the type species $N$. aloes (Crous \& M.J. Wingf.) Crous \& M.J. Wingf. based on phylogenetic analysis and unique morphological characters as compared to Phaeococcomyces de Hoog. The colonies of Neophaeococcomyces have chains of brown, budding cells that frequently remain attached (Moreno-Rico et al. 2014, Crous et al. 2015a).

Trichomeriaceae Chomnunti \& K.D. Hyde, Fungal Diversity 56: 66 (2013)

Index Fungorum number: IF800935; Facesoffungi number: FoF 10394

Epiphytes on living trees or saprobes on honeydew insect excretions. Thallus comprised of mycelium on host surface with septate, brown hyphae. Sexual morph: Ascostromata sessile, sphaerical, brown, uniloculate, ostiolate, surrounded by setae, smooth-walled. Setae brown to dark brown or olivaceous, erect, straight or curved, septate or continuous. Peridium comprising several layers of hyaline, pale brown to brown or olivaceous cells of textura angularis. Asci apparently bitunicate, cylindrical to clavate, with an apical ring. Ascospores 8-spored, overlapping 2-seriate, fusiform, round at ends, hyaline, 2-3-septate, with or without a mucilaginous sheath. Asexual morph: hyphomycetous.

Type - Trichomerium Speg.

Notes - Trichomeriaceae was introduced by Chomnunti et al. (2012b) represented by an epitype of $T$. foliicola Chomnunti \& K.D. Hyde. The family is characterized by sessile, setiferous ascomata, with ostioles, bitunicate asci with an apical ring and 2-3-septate, hyaline ascospores. Recently, several authors revealed that some asexual morph taxa were phylogenetically related to Trichomerium, viz., Arthrocladium, Bradymyces, Knufia, and Lithophila (Tsuneda et al. 2011, Réblová et al. 2013, Hubka et al. 2014, Isola et al. 2015, Nascimento et al. 2016). Most members of these genera inhabit bare rock, soil, air and are even pathogens of humans (Tsuneda et al. 2011, Réblová et al. 2013, Hubka et al. 2014, Isola et al. 2015, Nascimento et al. 2016). The taxonomic position of the non-sporulating taxa is ambiguous and they have been assigned to Trichomeriaceae and Chaetothyriaceae based on sequence similarity (Isola et al. 2015, Nascimento et al. 2016).

Trichomerium Speg., Physis, Rev. Soc. Arg. Cienc. Nat. 4(no. 17): 284 (1918)

Index Fungorum number: IF5560, Facesoffungi number: FoF 10395, 30 morphological species (Species Fungorum 2021), 14 species with molecular data.

Epiphytic on the upper surface of leaves. Hyphae, branched, septate, slightly constricted at the septa, pale brown to dark brown, hyphal networks covering the surface of hosts. Sexual morph: Ascomata superficial, solitary to aggregated, subglobose to globose, brown to dark brown, 
sometimes setose. Setae brown to dark brown or olivaceous, erect, straight or curved, septate or continuous. Peridium two layered, the outer layer of brown to dark brown cells of textura prismatica, the inner layer composed of pale brown to hyaline flattened cells. Hamathecium lacking paraphyses. Asci 8-spored, bitunicate, ellipsoidal to cylindrical, clavate, with a short pedicel, with an apical ring. Ascospores overlapping 2-seriate, hyaline, fusoid, rounded at the ends, 2-3-septate, guttulate, with or without a mucilaginous sheath. Asexual morph: hyphomycetous. Conidiophores reduced to conidiogenous cells, conidia arising directly from hyphae. Conidia solitary, hyaline to pale brown, or grayish, giving rise to 3-4 lateral arms from a central cell. Conidial arms subcylindrical, tapering to the apex, with rounded ends, pale brown to grayish, 2-5-septate, not constricted or slightly constricted, darker at the septa, smooth-walled (Hongsanan et al. 2016).
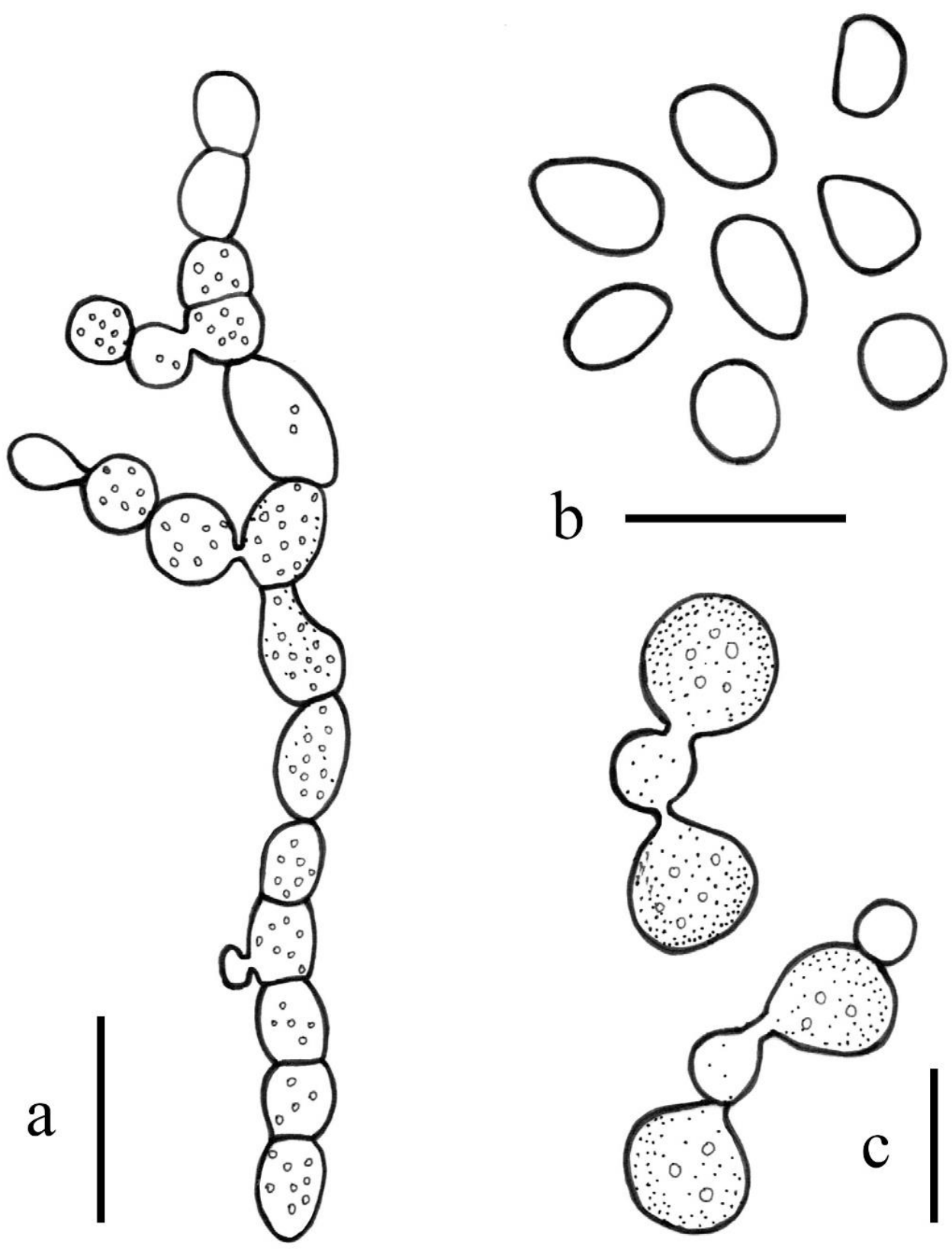

$\mathrm{b}$

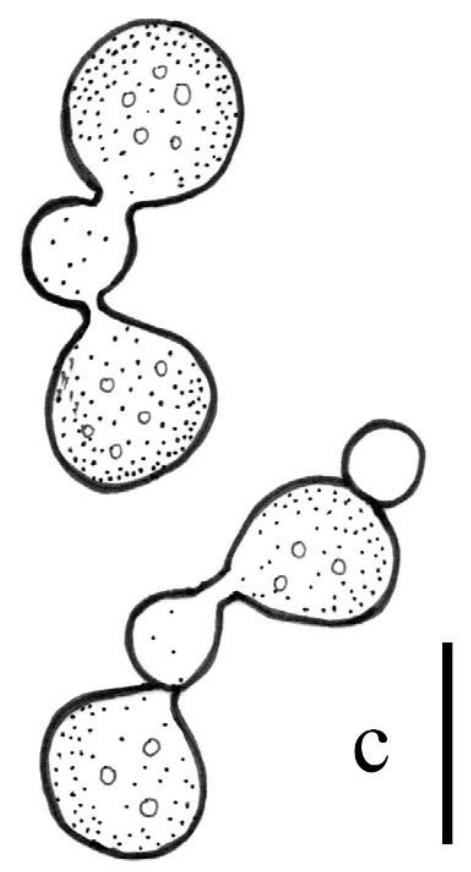

Figure 37 - Neophaeococcomyces aloes (CBS 136431, ex-type. redrawn from Crous et al. 2015a). $\mathrm{a}-\mathrm{c}$ Conidia and chlamydospore-like cells remaining attached to one another. Scale bars: $\mathrm{a}-\mathrm{c}=10$ $\mu \mathrm{m}$.

Type species - Trichomerium coffeicola (Puttemans) Speg. 
Notes - Trichomerium Speg. was introduced by Spegazzini (1918), with its type species T. coffeicola (Puttemans) Speg. However, because of the lack of holotype for T. coffeicola and lack of molecular data, Chomnunti et al. (2012) used T. foliicola as the type species of Trichomerium. The foliar epiphyte genus Trichomerium occurs superficially on living leaves of a variety of plants (Chomnunti et al. 2012b, Hongsanan et al. 2016, Maharachchikumbura et al. 2018). Crous et al. (2015) introduced a new species Trichomerium dioscoreae Crous \& C. Nakash. with tripospermum-like morphs. Subsequently, Hongsanan et al. (2016) introduced the asexual morph of Trichomerium gloeosporum Chomnunti \& K.D. Hyde with tripospermum-like morphs, which was confirmed with on phylogenetic analysis. Yang et al. (2021) reported three sexual morphic species, viz. T. multisetosum, T. xishuangbannaense and T. yunnanense, associated with plant leaves from China based on distinct morphologically characters and phylogenetic analyses of ITS and LSU combined sequences.

Trichomerium coffeicola (Puttemans) Speg., Physis, Rev. Soc. Arg. Cienc. Nat. 4(no. 17): 284 (1918)

三Limacinia coffeicola Puttemans, Bull. Soc. mycol. Fr. 20: 153 (1904)

Fig. 38

For synonyms see Species Fungorum

Index Fungorum number: IF340357; Facesoffungi number: FoF 10396

Epiphytic on the upper surface of leaves. Hyphae, branched, septate, slightly constricted at the septa, pale brown to dark brown, hyphal networks cover the surface of hosts. Sexual morph: Ascomata 70-95 high diam. ( $\overline{\mathrm{x}}=83 \mu \mathrm{m}, \mathrm{n}=5)$, superficial, solitary to aggregated, subglobose to globose, brown to dark brown. Peridium $12-18 \mu \mathrm{m}$ wide $(\overline{\mathrm{x}}=12 \mu \mathrm{m}, \mathrm{n}=10)$, two layered, outer layer of brown to dark brown cells of textura prismatica, inner layer composed of pale brown to hyaline flattened cells. Hamathecium lacking paraphyses. Asci $35-45 \times 10-12 \mu \mathrm{m}(\overline{\mathrm{x}}=40 \times 11 \mu \mathrm{m}$, $\mathrm{n}=10$ ), 8 -spored, bitunicate, ellipsoidal to cylindrical, clavate, with a short pedicel, with an apical ring. Ascospores $8-12 \times 2.5-3.5 \mu \mathrm{m}(\overline{\mathrm{x}}=10 \times 3 \mu \mathrm{m}, \mathrm{n}=10), 2$-seriate, hyaline, fusoid, rounded at the ends, 2-3-septate, guttulate, with a mucilaginous sheath. Asexual morph: Undetermined.

Material examined - Cuba, Habana, on leaves of Eugenia axillaris (Sw.) Willd. (Myrtaceae), 1 February 1922, Reginald Hart. \& Charles H. Ballou (BPI 699599A-C).

\section{Other genera included:}

Arthrocladium Papendorf, Trans. Br. mycol. Soc. 52(3): 483 (1969)

Index Fungorum number: IF7220, Facesoffungi number: FoF 10397, 4 morphological species (Species Fungorum 2021), 4 species with molecular data.

Biotrophic, saprobic, pathogenic on plant tissue, ant domatium and humans. Sexual morph: Undetermined. Asexual morph: hyphomycetous. Hyphae septate, light smoky brown, Conidiophores terminally, distinct, light brown-olivaceous. Conidia solitary, filamentous with proximal articulate spore-body, septate, tapering to the apex, with tail-like extensions, light brownolvaceous, smooth-walled (Papendorf 1969). (1969)

Type species - Arthrocladium caudatum Papendorf, Trans. Br. mycol. Soc. 52(3): 483

Index Fungorum number: IF326486

Fig. 39

Type material - South African, Northern Province, from soil (PRE 43727, holotype).

Notes - Papendorf (1969) introduced Arthrocladium Papendorf to accommodate the type species A. caudatum Papendorf from leaf litter of Acacia in South Africa. The genus is characterized by obsolete or distinct, light brown-olivaceous conidiophores and light brownolivaceous conidia with tail-like extensions. Sequencing of the type strain of Arthrocladium caudatum revealed that the genus is related to Knufia within Trichomeriaceae. Nascimento et al. (2016) introduced three non-sporulating species of Arthrocladium, but the conidia description did not agree with those of Papendorf (1969). They described structures as irregular fragmentation of swollen hypha. Due to their nondescript morphology, Arthrocladium species may have been overlooked in ecological studies. 

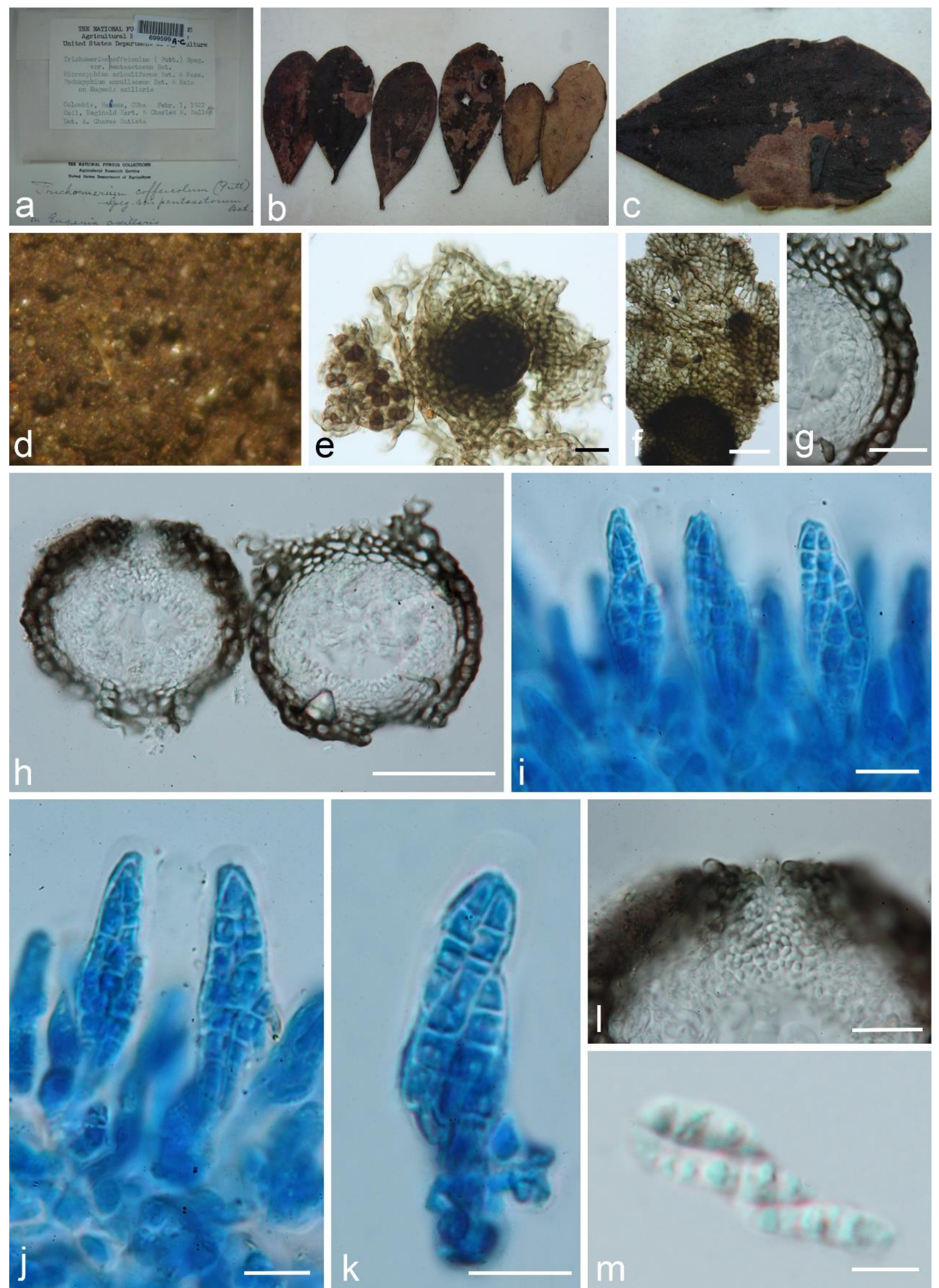

Figure 38 - Trichomerium coffeicola (BPI 699599A-C). a Envelop and collection information of Trichomerium coffeicola. b, c Herbarium material. d Appearance of ascomata superficial on the host. e, f Squash mount of ascoma. g Vertical section through ascoma wall. h Vertical section of ascomata. i-k Asci with ascospores, stained in lactophenol cotton blue. 1 Vertical section through ostiole. $\mathrm{m}$ Ascospores. Scale bars: $\mathrm{e}-\mathrm{g}, \mathrm{l}=20 \mu \mathrm{m}, \mathrm{h}=50 \mu \mathrm{m}, \mathrm{i}-\mathrm{k}=10 \mu \mathrm{m}, \mathrm{m}=5 \mu \mathrm{m}$. 


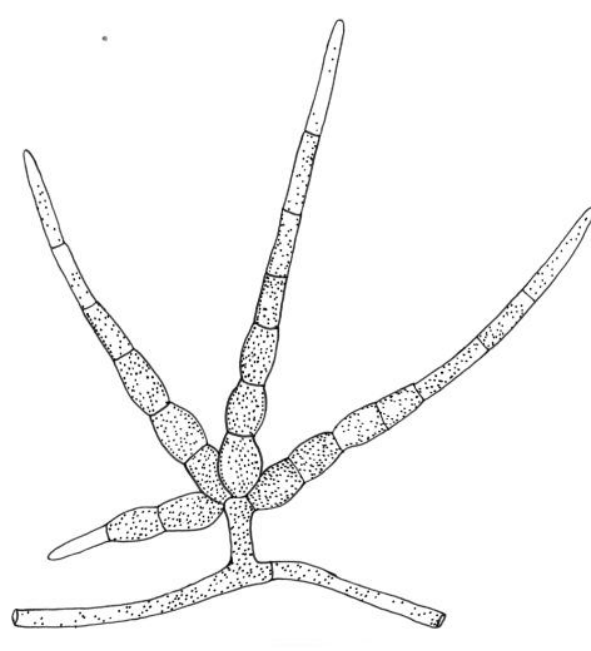

a

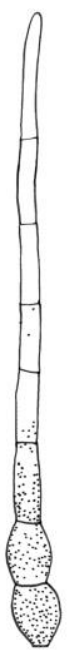

b

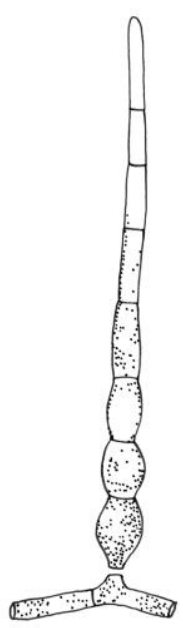

c

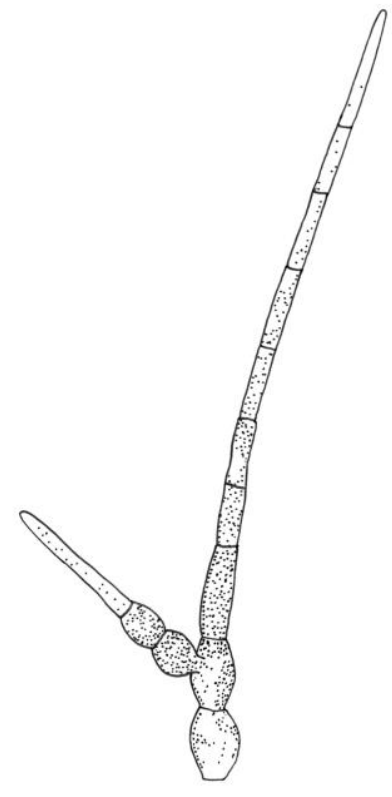

d

Figure 39 - Arthrocladium caudatum (PRE 43727, holotype, redrawn from Papendorf 1969). a, d Conidiophores with single and grouped conidia. b, c Lateral conidia showing stipitate and truncate base and septate basal cell. Scale bars: $a-d=10 \mu \mathrm{m}$.

Bradymyces Hubka, Réblová, Selbmann \& M. Kolařík, Antonie van Leeuwenhoek 106(5): 983 (2014)

Index Fungorum number: IF808780, Facesoffungi number: FoF 10398, 3 morphological species (Species Fungorum 2021), 3 species with molecular data.

Biotrophic, hemibiotrophic or saprobic on leaves and stems of various plants in terrestrial habitats. Sexual morph: Undetermined. Asexual morph: hyphomycetous. Mycelium comprising branched, melanized, cylindrical or moniliform, septate hyphae. Blastic proliferation formed at the ends of moniliform hyphae, terminal cells swollen with umbonate apices and conspicuously larger than the subterminal cells. Bodies uni- or multi-cellular, dark brown, develop in an intercalar and terminal position on the hyphae with longitudinal as well as vertical septa. Endoconidia rare, unicellular, globose or subglobose, in terminal or intercalary cells. Vegetative hyphae may disintegrate into one-celled or multicellular fragments. Uni- or multi-cellular bodies are present in the centre of older colonies, sometimes with dark-brown crusts and excoriations on the surface (Hubka et al. 2014).

Type species - Bradymyces oncorhynchi Hubka, Řehulka, Réblová \& M. Kolařík, Antonie van Leeuwenhoek 106(5): 985 (2014)

Fig. 40

Index Fungorum number: IF808781

Type material - Czech Republic, isolated from a hyperaemic focus near the enlarged spleen of Oncorhynchus mykiss Walbaum (Salmoninae), 2011, J. Řehulka (PRM 861507, holotype; CCF 4369T $=$ CBS 133066T $=$ CCFEE 6134T, ex-type).

Notes - Bradymyces Hubka et al. was introduced by Hubka et al. (2014) to accommodate two species, viz., B. alpinus Hubka et al. and B. oncorhynchi Hubka et al., isolated from a hyperaemic focus near the enlarged spleen of Oncorhynchus mykiss and rocks respectively. The genus is characterized by moniliform hyphae, blastic proliferation, endoconidia, multicellular and muriform bodies, and bodies with dark fragmented incrustations on the surface (Hubka et al. 2014). Bradymyces can be distinguished from the majority of the Trichomeriaceae by morphology. Based on phylogenetic, ecophysiological and morphological data, Bradymyces is presently classified in Trichomeriaceae (Fig. 1). 

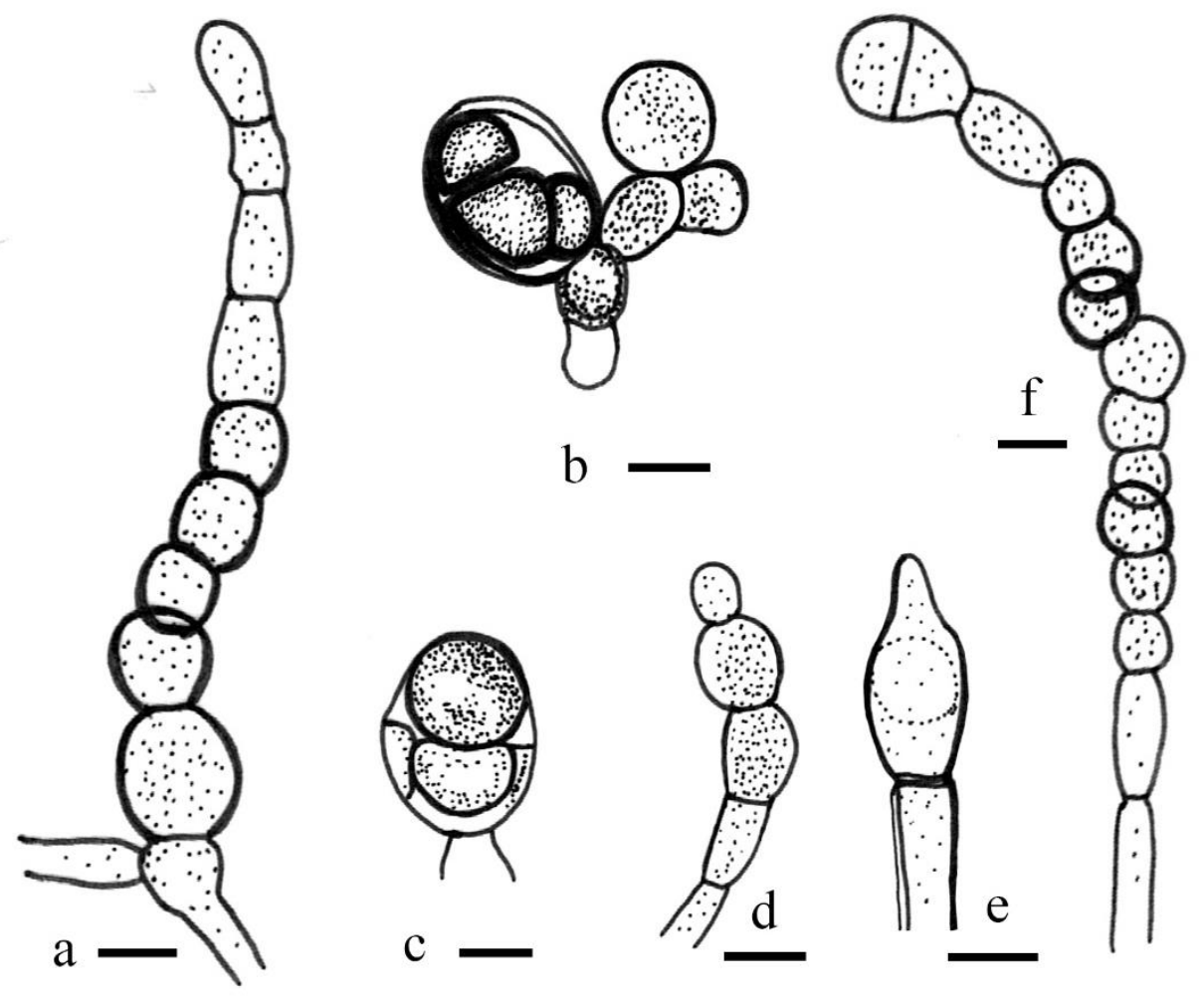

Figure 40 - Bradymyces oncorhynchi (redrawn from Hubka et al. 2015). a, f Moniliform hyphae. b Multicellular bodies. c Endoconidia. d, e Blastic proliferation from terminal cell by yeast like budding. Scale bars: $\mathrm{a}-\mathrm{f}=5 \mu \mathrm{m}$.

Knufia L.J. Hutchison \& Unter., Mycologia 87(6): 903 (1996) [1995]

Index Fungorum number: IF27605, Facesoffungi number: FoF 10399, 19 morphological species (Species Fungorum 2021), 12 species with molecular data.

Pathogenic on humans or saprobic on leaves and insects, lichenicolous, rock-inhabiting in terrestrial habitats. Sexual morph: Undetermined. Asexual morph: hyphomycetous. Colonies in axenic culture black, slow-growing. Hyphae cylindrical to moniliform, subhyaline to brown, septate, smooth-walled. Conidiogenous cells holoblastic, terminal or lateral, produced on undifferentiated hyphae. Conidia obovate to cylindrical, subhyaline to brown, aseptate to multiseptate. Phialides obclavate. Phialoconidia cylindrical to pyriform, hyaline, aseptate.

Type species - Knufia cryptophialidica L.J. Hutchison \& Unter., Mycologia 87(6): 903 (1996) [1995]

Fig. 41

Index Fungorum number: IF434448

Type material - Alberta, isolated from black gall on stems and branches of Populus tremuloides Michx. (Salicaceae) (TRTC 51492, holotype).

Notes - The black-yeast genus Knufia L.J. Hutchison \& Unter. was introduced by Hutchison \& Untereiner (1995) to accommodate $K$. cryptophialidica L.J. Hutchison \& Unter. The diagnostic features of Knufia are that have the black, slow-growing colonies and undifferentiated, holoblastic, conidiogenous cells on the hyphae. Darkly pigmented, enlarged multicellular bodies are reliable characteristics to differentiate species, as well as the phialides (Hutchison \& Untereiner 1995, Tsuneda et al. 2004, 2005, 2011, Sun et al. 2020). Only the ex-type species has phialidic conidia. Knufia peltigerae (Fuckel) Réblová \& Unter. and K. perfecta Mehrabi, Asgari \& Hemmati, are the sexual morph species of this genus (Untereiner et al. 2011, Réblová et al. 2013, Mehrabi et al. 2018) with superficial, dark, setose ascomata, bitunicate, sessile asci and hyaline, septate, ellipsoidal to fusiform ascospores (Untereiner et al. 2011, Mehrabi et al. 2018). Tsuneda \& Currah (2005) suggested discontinuing the characters of phialidic conidia in the genus. Knufia are black- 
yeasts in Trichomeriaceae. Some allied species, are congeneric and have been transferred to Knufia because of their close phylogenetic relationships (Hawksworth et al. 1987, Tsuneda et al. 2011, Réblová et al. 2013, He et al. 2014, Crous et al. 2019b, Sun et al. 2020) shown based on multigenes phylogenetic analyses.

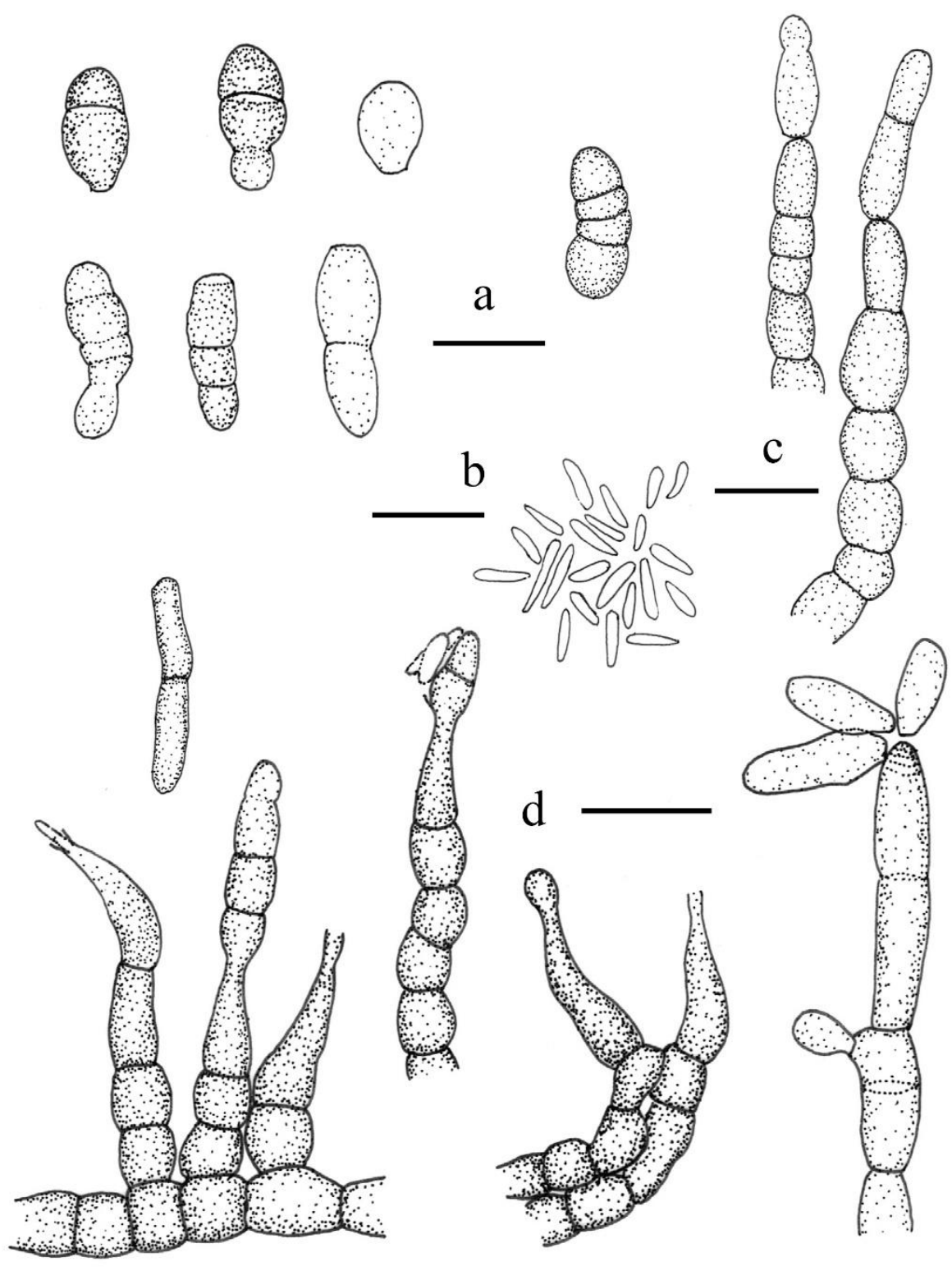

Figure 41 - Knufia cryptophialidica (redrawn from Hutchison et al. 1995). a Conidia. b Phialides and phialoconidia from MEA (DAOM 216555). c Conidiogenous cells on MLA (DAOM 216555). $\mathrm{d}$ Conidiogenous cells on MEA (DAOM 216554). Scale bars: $\mathrm{a}-\mathrm{d}=10 \mu \mathrm{m}$.

Lithohypha Selbmann \& Isola, Fungal Diversity 86(1): 258 (2017)

Index Fungorum number: IF819853, Facesoffungi number: FoF 10400, 3 morphological species (Species Fungorum 2021), 3 species with molecular data.

Isolated from marble stone or ornamental limestone. Sexual morph: Undetermined. Asexual morph: Colonies growing slowly, cauliflower-shaped, dark brown, velvety with irregularly lobate margin from above, black from below. Hyphae branched, pale brown, composed of simple to multiseptate, catenate cells produced by enteroblastic proliferation. Globose cells frequently produced intercalarly, terminarly or laterally, 1-multicellular, sometimes with endoconidia (Isola et al. 2016, Crous et al. 2019b). 
Type species - Lithohypha guttulata Selbmann \& Isola, Fungal Diversity 86(1): 258 (2017)

For synonyms see Species Fungorum

Index Fungorum number: IF819854

Notes - Lithohypha Selbmann \& Isola was introduced by Wijayawardene et al. (2017) to revise the illegitimate and unavailable name Lithophila Selbmann \& Isola. Isola et al. (2016) introduced Lithophila Selbmann \& Isola in Trichomeriaceae, which is a later homonym of Lithophila Sw., a name previously and validly published for a genus of Amaranthaceae. Lithohypha is characterized by slow growing, cauliflower-shaped colonies, branched, irregularly-shaped, simple to multiseptate, catenate hyphal cells and globose, dark cells generally enlarged to form multicellular bodies which probably function as resistance structures. Currently, L. aloicola Crous, L. catenulata L. Su et al. and L. guttulata Selbmann \& Isola (type species) are included in this genus (Wijayawardene et al. 2017, Crous et al. 2019a, Sun et al. 2020). Phylogenetic analysis showed Lithohypha forms a sister group to Strelitziana and is aligned in Trichomeriaceae (Fig. 1).

Neostrelitziana Crous \& M.J. Wingf., Persoonia 34: 187 (2015)

Index Fungorum number: IF812428, Facesoffungi number: FoF 10401, 1 morphological species (Species Fungorum 2021), 1 species with molecular data.

Pathogenic on leaves causing leaf spots. Sexual morph: Undetermined. Asexual morph: Mycelium comprising branched, pale brown, septate, smooth-walled hyphae. Conidiophores reduced to conidiogenous cells. Conidiogenous cells solitary on hyphae, phialidic, subcylindrical, pale brown, smooth, curved. Conidia solitary, subcylindrical to slightly clavate, with a slight taper in the basal third of collarette, pale brown, straight to curved, septate, smooth, granular, base with long, curved, to S-curved collarette, cylindrical, pale brown (adapted from Crous et al. 2015a).

Type species - Neostrelitziana acaciigena Crous \& M.J. Wingf., Persoonia 34: 187 (2015)

Index Fungorum number: IF811417

Type material - Malaysia, Sabah, on leaf spots of Acacia mangium Willd. (Leguminosae), May 2014, M.J. Wingfield (CBS H-22232, holotype; CPC 24873 = CBS 139903, ex-type).

Notes - Neostrelitziana Crous \& M.J. Wingf. was introduced by Crous et al. (2015a) with the type species $N$. acaciigena Crous \& M.J. Wingf. from leaf spots of Acacia mangium. Neostrelitziana acaciigena fits the characters with Strelitziana, while Neostrelitziana acaciigena formed a distinct clade away from Strelitziana (Crous et al. 2015a and Fig. 1). Neostrelitziana acaciigena has curved, to S-shaped collarettes, but Strelitziana has short and straight collarettes. It is therefore a distinct genus.

Strelitziana Arzanlou \& Crous, Fungal Planet 8: [1] (2006)

Index Fungorum number: IF501009, Facesoffungi number: FoF 10402, 8 morphological species (Species Fungorum 2021), 8 species with molecular data.

Pathogenic or saprobic on stems, fruits and leaf spots of various plants. Sexual morph: Undetermined. Asexual morph: hyphomycetous. Conidiophores erect, solitary, arising from aerial and submerged mycelium, subcylindrical, straight to geniculous-sinuous, pale brown. Conidiogenous cells terminal, integrated, phialidic, rejuvenating percurrently, proliferating apically via several short, denticles conspicuous, conidiogenesis rhexolytic. Conidia pale obclavate, long, brown, multi-euseptate, smooth-walled. Microcyclic conidiation present in culture (Arzanlou \& Crous 2006).

Type species - Strelitziana africana Arzanlou \& Crous, Fungal Planet, A Global Initiative to Promote the Study of Fungal Biodiversity 8: [1] (2006)

Fig. 43

Index Fungorum number: IF501010

Type material - South Africa, KwaZulu-Natal, Durban, Botanical Garden near Reunion, on leaves of Strelitzia sp. (Strelitziaceae), 5 February 2005, W. Gams \& H. Glen (CBS-H 19776, holotype; X1039 = CBS 120037, ex-type). 
Notes - Strelitziana africana Arzanlou \& Crous was isolated from leaves of Strelitzia sp. Based on its distinct morphology and phylogenetic analysis, currently eight species are accepted in Strelitziana (Trichomeriaceae) (Arzanlou \& Crous 2006).
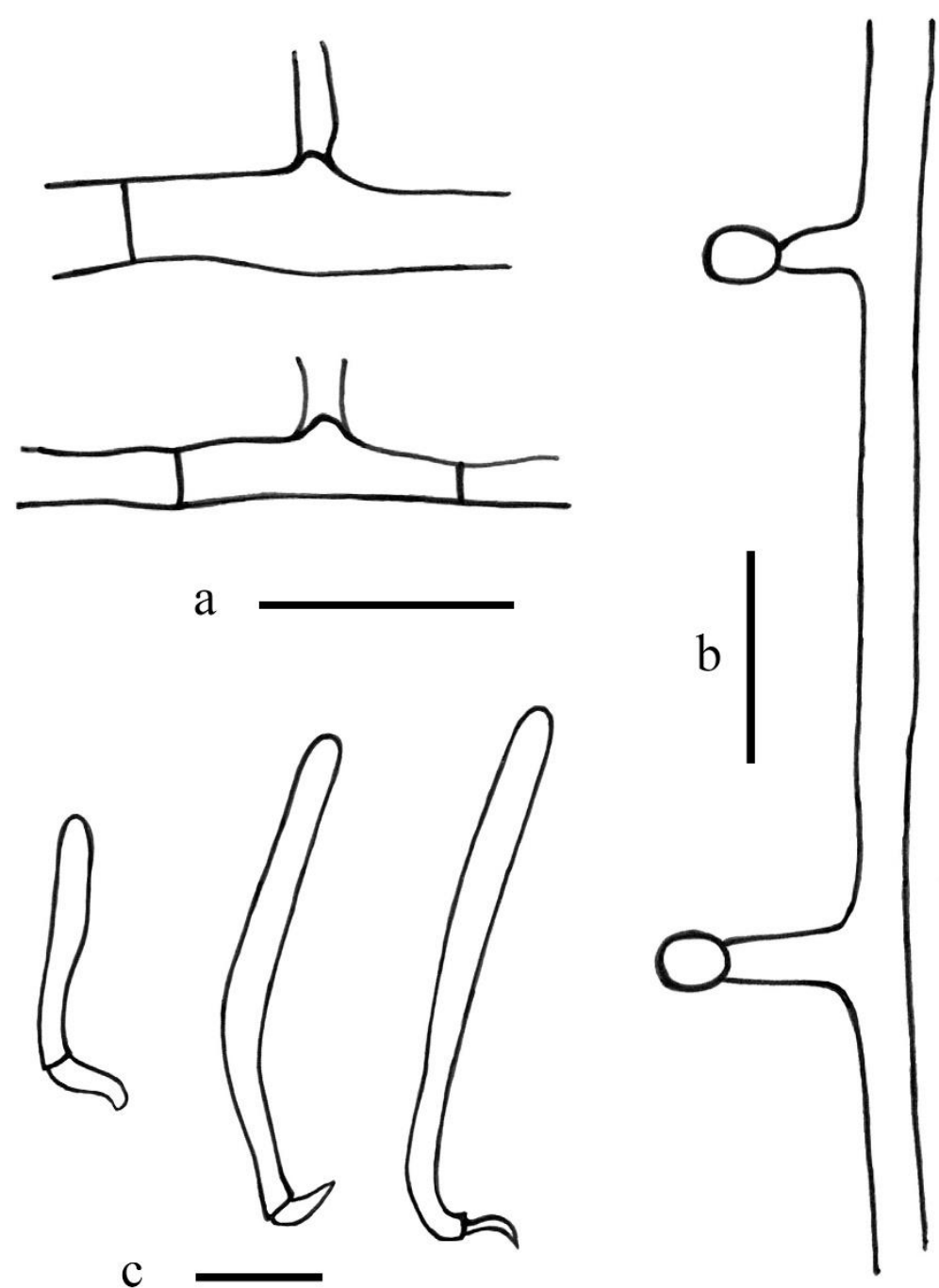

Figure 42 - Neostrelitziana acaciigena (redrawn from Crous et al. 2015a), a, b Conidiogenous cells. c Conidia. Scale bars: $\mathrm{a}-\mathrm{c}=10 \mu \mathrm{m}$.

Chaetothyriales genera incertae sedis

Bacillicladium Hubka, Réblová \& Thureborn, PLoS ONE 11(10): e0163396, 14 (2016)

Index Fungorum number: IF816983, Facesoffungi number: FoF 10403, 2 morphological species with molecular data.

Saprobic on a branch of Clematis vitalbae and bare granite walls in terrestrial habitats. Sexual morph: Undetermined. Mycelium immersed to superficial, composed of branched, pale brown, septate, swollen and constricted at septa in the conidiogenous region, with smooth-walled hyphae, individual cells ellipsoid and clavate to globose in the conidiogenous region. Asexual morph: hyphomycetous. Conidiophores reduced to conidiogenous cells, phialidic, pale brown, with inconspicuous collarette, not flared, smooth-walled. Conidia solitary, acrogenous, ellipsoid, obtuse towards the apex, truncate at the base, pale brown, aseptate, straight, guttulate, smooth-walled, older conidia undergoing microcyclic conidiation. Uni- or multicellular bodies are formed in culture, single or in chains. 
Type - Bacillicladium lobatum Hubka, Réblová \& Thureborn, PLoS ONE 11(10): e0163396, 17 (2016)

Index Fungorum number: IF816984

Type material - Sweden, Stockholm, Kungsträdgårdens metro station, bare granite walls, 15 July 2015, O. Thureborn, S1K1 (PRM 935094, holotype; CCF 5200 = CBS 141179, ex-type).

Notes - Bacillicladium lobatum Hubka et al. was isolated from bare granite walls and has three different growth modes in vitro, dependent on cultivation medium, temperature and colony age. Bacillicladium clematidis Crous \& R.K. Schumach was associated with a branch of Clematis vitalbae and has black yeast-like growth in culture (Réblová et al. 2016, Crous et al. 2019b). Bacillicladium formed a monophyletic clade close to Trichomeriaceae with low bootstrap support. The morphology does not fit any genera in Trichomeriaceae or other families in Chaetothyriales, thus, the placement of Bacillicladium is uncertain.

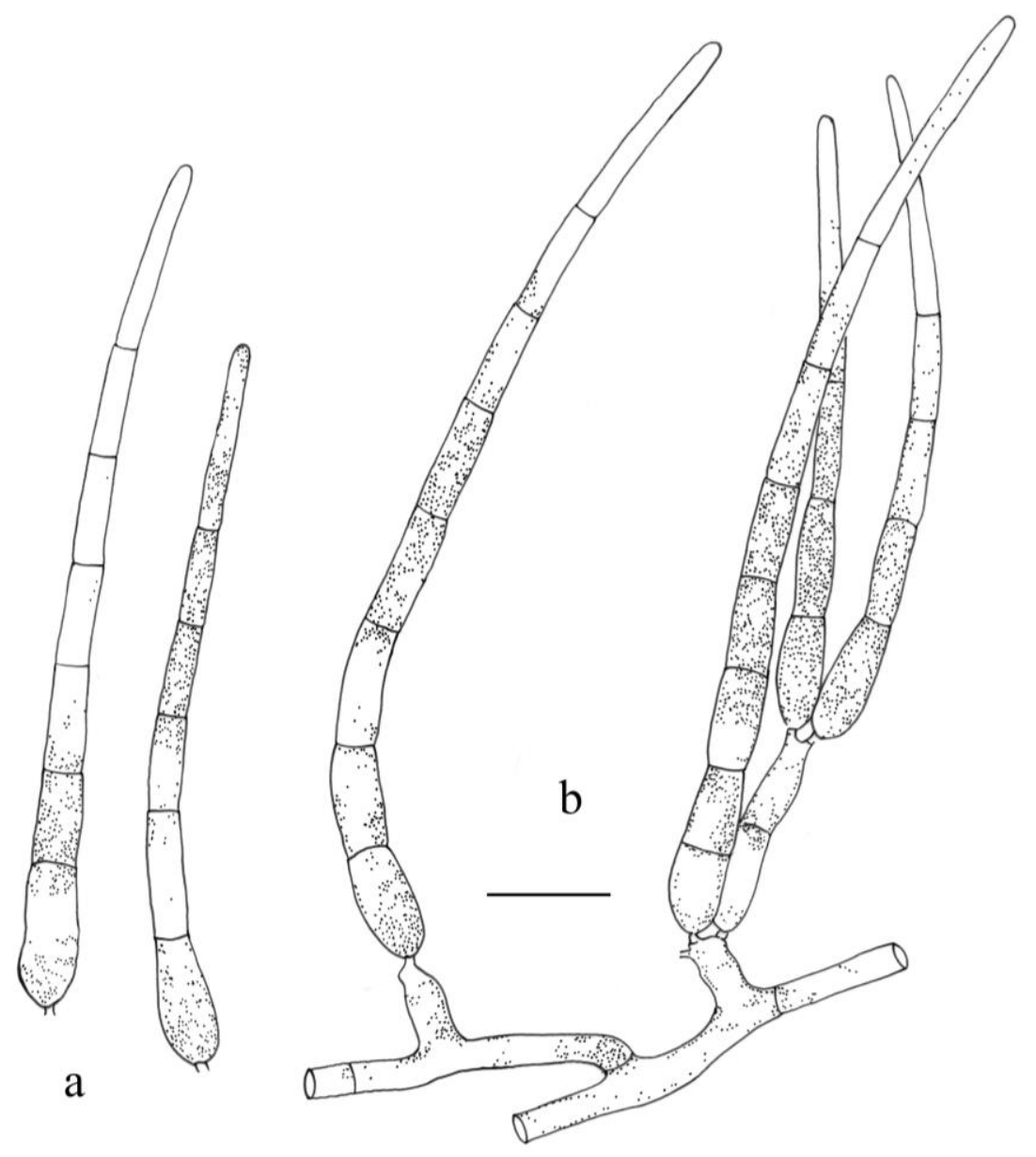

Figure 43 - Strelitziana africana (PRE 43727, holotype, redrawn from Papendorf 1969). a Conidia. $\mathrm{b}$ Conidiogenous cell giving rise to conidia. Scale bars: $\mathrm{a}, \mathrm{b}=10 \mu \mathrm{m}$.

Euceramia Bat. \& Cif., Beih. Sydowia 3: 121 (1962)

Index Fungorum number: IF1915, Facesoffungi number: FoF 10346, 1 morphological species (Species Fungorum 2021), molecular data unavailable.

Type species - Euceramia palmicola Bat. \& Cif.

Epiphytic on leaves in terrestrial habitats. Colonies effuse, superficial. Mycelium composed of superficial, branched, septate, brown to dark brown hyphae. Sexual morph: Ascomata perithecial, superficial, covering the leaf surface with dark mycelium without penetrating host tissues, multi-locular, globose to subglobose, brown to dark brown, membranaceous, pseudo-ostiolate, glabrous, smoothwalled. Ostiole inconspicuous. Wall of ascoma comprising two cell types, externally comprising 
pigmented, dark brown, thick-walled cells of textura globulosa and inner layer thinner, composed of lightly pigmented to hyaline, thin-walled cells of textura angularis. Hamathecium comprising filiform, hyaline, septate, branched paraphyses. Asci 8-spored, unitunicate, sessile. Ascospores irregularly arranged, clavate-fusoid to cylindrical, hyaline, pluriseptate, 4-6-septate, constricted at the septa, smooth-walled, lacking a gelatinous sheath or appendages. Asexual morph: Undetermined (Batista \& Ciferri 1962).

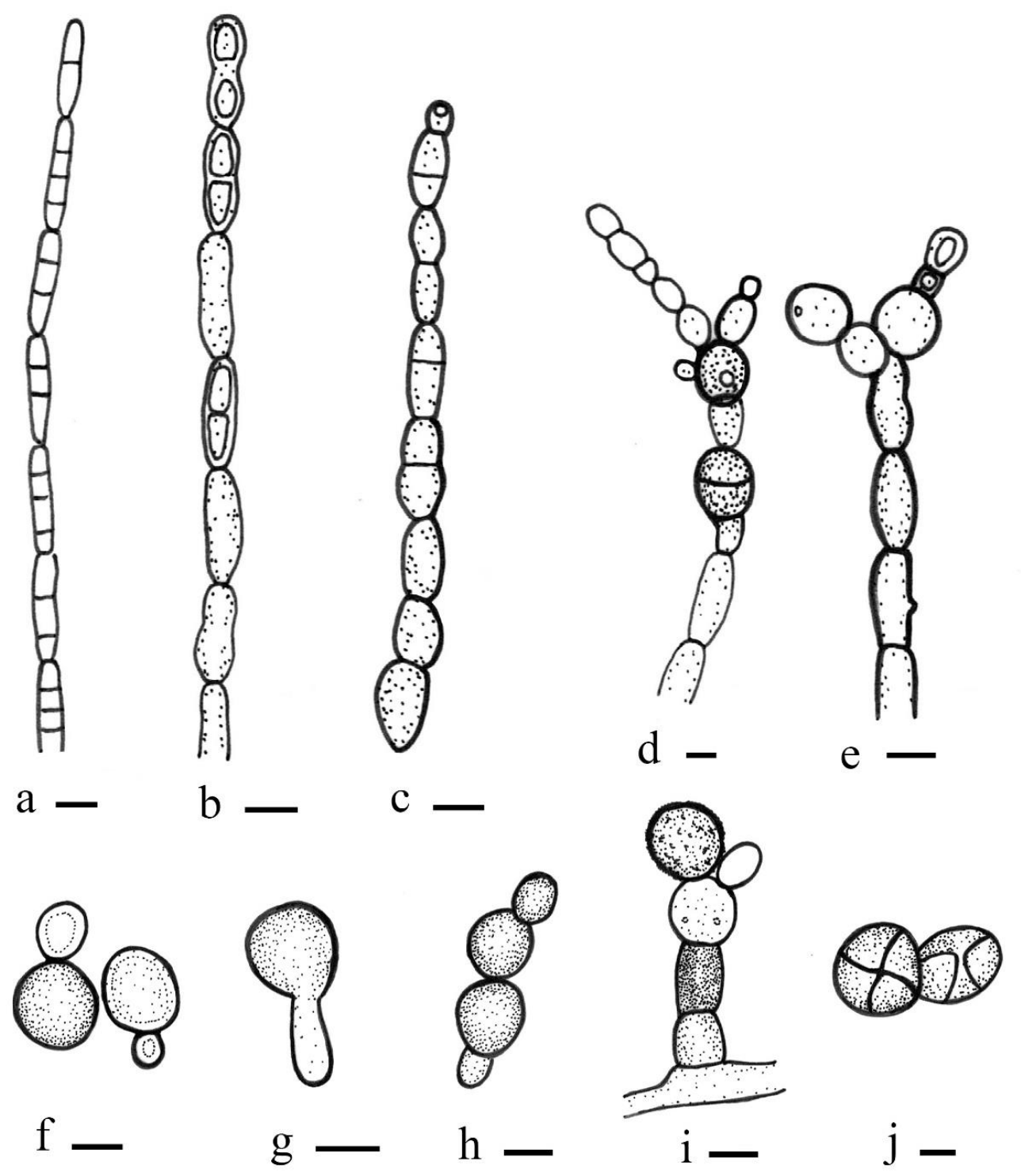

Figure 44 - Bacillicladium lobatum (CBS 141179, ex-type, redrawn from Réblová et al. 2016). a-c Unbranched hyphae. d, e Unbranched or sparsely branched vegetative hyphae from the deeper parts of the colonies. $\mathrm{f}-\mathrm{h}$ Yeast-like stage, budding and forming short chains. i Fungal elements from the inner parts of the colony with incrustations on their surface. $\mathrm{j}$ Multicellular bodies. Scale bars: $\mathrm{a}-\mathrm{j}=5 \mu \mathrm{m}$.

Notes - Euceramia Bat. \& Cif. was introduced to represent the monotypic family Euceramiaceae Bat. \& Cif., with the species E. palmicola Bat. \& Cif. It is characterized by having plurilocular perithecia, filiform paraphyses, unitunicate asci and cylindrical ascospores. Lumbsch \& Huhndorf (2010) and Kirk et al. (2013) listed Euceramia to Chaetothyriaceae. Consistent with their conclusion, Chomnunti et al. (2012a, 2014) referred Euceramia as sooty moulds because of their morphological and ecological similarity which fits the description of Chaetothyriaceae. Considering the unique unitunicate 
asci, Euceramia is not accepted in Chaetothyriaceae. Hence, we place it as Chaetothyriales genera, incertae sedis, pending epitypification or neotypification of fresh collections and DNA sequences.

Euceramia palmicola Bat. \& Cif., Beih. Sydowia 3: 123 (1962)

Fig. 45

Index Fungorum number: IF330710; Facesoffungi number: FoF 10347

Description: see Batista and Ciferri (1962)

Type material - Brazil, on leaves of Cocos nucifera L. (Arecaceae), 1 May 1956, Washington Amorim (Institute of Mycology, University of Recife, Type 4572, holotype).

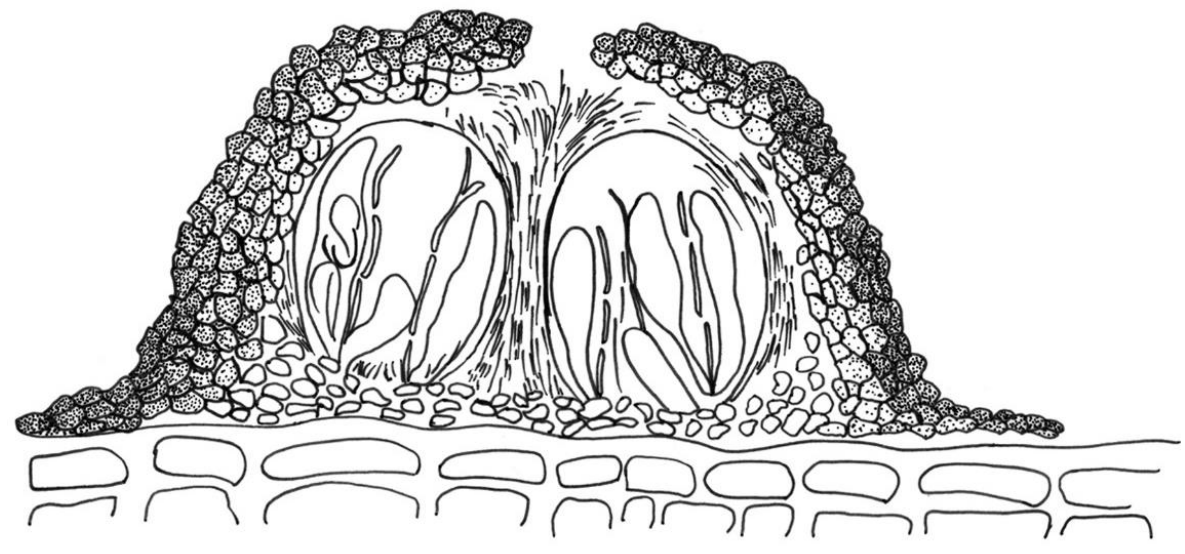

$\mathrm{a}-$
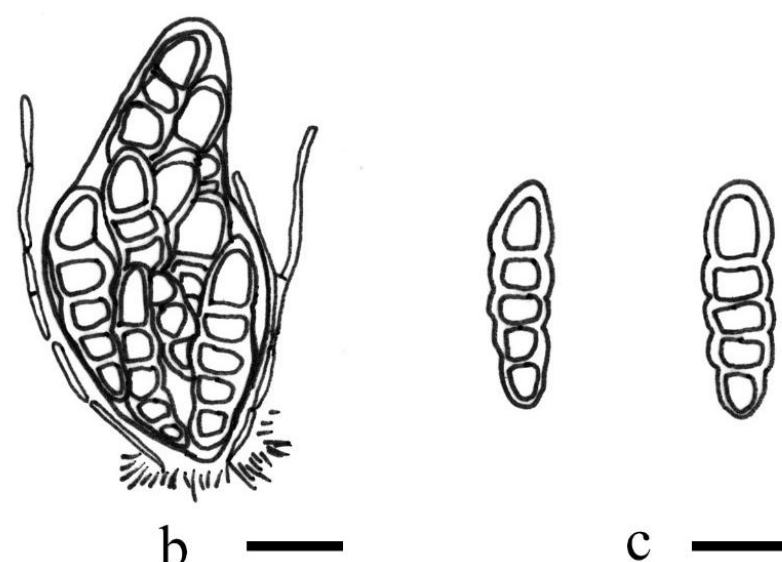

Figure 45 - Euceramia palmicola (Type 4572, holotype, redrawn from Batista \& Ciferri 1962). a Vertical section of ascoma. b Ascus. c Ascospores. Scale bars: $10 \mu \mathrm{m}$.

Lichenodiplis Dyko \& D. Hawksw., Lichenologist 11(1): 51 (1979)

Index Fungorum number: IF8773, Facesoffungi number: FoF 10404, 14 morphological species (Species Fungorum 2021), 1 species with molecular data.

Saprobic on dead twigs of various plants in terrestrial habitats. Sexual morph: Undetermined. Asexual morph: Coelomycetous. Conidiomata pycnidial, scattered, immersed to erumpent, unilocular, globose to subglobose or slightly obpyriform, black, opening by an irregular pore. Conidiomata wall several layers, composed of hyaline to brown paraplectenchymatous cells. Conidiophores reduced to conidiogenous cells. Conidiogenous cells integrated, terminal, determinate, phialidic, simple to strongly branched, lageniform to cylindrical, pale olivaceous brown to brown, smooth-walled. Conidia solitary, acrogenous, ellipsoidal, with truncate base and a persistent marginal frill, subhyaline to pale brown, 1-septate, straight or curved, smooth-walled or verrucose-walled at maturity (Hawksworth \& Dyko 1979).

Type species - Lichenodiplis lecanorae (Vouaux) Dyko \& D. Hawksw., Lichenologist 11(1): $52(1979)$ 
Index Fungorum number: IF316910

Notes - Lichenodiplis Dyko \& D. Hawksw. was originally assigned to Sphaeropsidales Bessey (Hawksworth \& Dyko 1979), an order traditionally used for asexual taxa with pycnidial conidiomata. The lichenicolous genera, Lichenodiplis and Muellerella may be sexual and asexual morphs. Lichenodiplis lecanorae formed a monophyletic clade, sister to Epibryon (Epibryaceae) in Chaetothyriales (Fig. 1). The morphology of Lichenodiplis does not fit with other related families and therefore we place this lichenized coelomycetous genus in Chaetothyriales.

Melanina Grube, Muggia \& de Hoog, Mycol. Progr. 20(7): 921 (2021)

Index Fungorum number: IF838740, 1 morphological species with molecular data.

Description: see Muggia et al. (2021).

Type species - Melanina gundecimermaniae Grube, Muggia \& de Hoog, Mycol. Progr. 20(7): 922 (2021)

Index Fungorum number: IF838767

Notes - Melanina Grube et al. was introduced by Muggia et al. (2021) isolated from epilithic, crust-forming lichens in subalpine habitats. The endolichenic genus is characterized by toruloid hyphae, a yeast-like growth in the central internal part of the colony and pale, pigmented, conidia in chains (Muggia et al. 2021). Melanina is supported as a distinct lineage within the order Chaetothyriales, while the morphological characters cannot fit any family in Chaetothyriales, thus, Muggia et al. (2021) the placed the genus in an uncertain placement in Chaetothyriales based on phylogenetic analysis.

\section{Genera excluded from Chaetothyriales}

Microcallis Syd., Annls mycol. 24(5/6): 337 (1926)

Index Fungorum number: IF3157, Facesoffungi number: FoF 10348, 9 morphological species (Species Fungorum 2021), molecular data unavailable.

Epiphytic on the lower surface of leaves, appearing as black dots scattered, hypophyllous. Mycelium composed of branched-reticulate, septate, olivaceous to blackish-brown hyphae. Sexual morph: Ascomata scattered, developing beneath the mycelial pellicle, globose-depressed, attaching it to the leaf surface, olivaceous-brown, membranous, pseudo-ostiolate. Setae scattered, dark brown to black, erect, obtuse. Wall of ascoma pseudoparenchymatous, composed of textura angularis outside, becoming light brown and flattened in the inner region. Asci 8-spored, bitunicate, clavate to ellipsoid, subsessile or sessile. Ascospores overlapping bi-seriate or multi-seriate, oblong-clavate, hyaline, 1septate, constricted at the septum, thick-walled, smooth-walled, without a mucilaginous sheath. Asexual morph: Undetermined.

Type species - Microcallis phoebes Syd.

Notes - Microcallis Syd. is characterized by globose-depressed ascomata with dark brown to black setae, developing beneath a mycelial pellicle, bitunicate asci, and oblong-clavate, 1-septate ascospores (Sydow 1926, Batista \& Ciferri 1962). It was initially placed in Chaetothyriaceae (Sydow 1926, Hansford 1946). Hansford (1946) proposed that the ascomata are too flat, which may be an inaccurate description initially, but he confirmed the position of Microcallis in Chaetothyriaceae, rather than Micropeltidaceae Clem. \& Shear. Petrak \& Sydow (1934) transferred four species, including the type species $M$. phoebes Syd., M. amadelpha Syd., M. consociata Syd., and M. megalospora Petrak \& Cif. to Chaetothyrina Theiss. (Micropeltidaceae, Microthyriales, Dothideomycetes). Microcallis phoebes shares similar characters with species in Chaetothyrina, hence, we excluded Microcallis from Chaetothyriaceae and assign this genus to Micropeltidaceae.

Microcallis phoebes Syd., Annls mycol. 24(5/6): 338 (1926)

Fig. 46

Index Fungorum number: IF274276; Facesoffungi number: FoF 10349

Epiphytic on the lower surface of leaves, appearing as black dots scattered. Mycelium 2-3.5 $\mu \mathrm{m}$, composed of branched-reticulate, septate, olivaceous to blackish-brown hyphae. Sexual morph: Ascomata $75-180 \times 30-50 \mu \mathrm{m}(\overline{\mathrm{x}}=148 \times 43 \mu \mathrm{m}, \mathrm{n}=10)$, scattered, developing beneath a mycelial 
pellicle, globose-depressed, attaching it to the leaf surface, olivaceous-brown, membranous, pseudoostiolate. Setae 140-250 $\times 2-5 \mu \mathrm{m}$, wider at the base and tapering to the apex, scattered, dark brown to black, erect, obtuse. Wall of ascoma up to $50 \mu \mathrm{m}$ thick, pseudoparenchymatous, composed of cells of textura angularis at the outside, becoming light brown and flattened in the inner region. Hamathecium 1-2.5 $\mu \mathrm{m}$, comprising filiform, hyaline, septate, branched paraphyses. Asci $28-55 \times 12-18 \mu \mathrm{m}(\overline{\mathrm{x}}=42$ $\times 15 \mu \mathrm{m}, \mathrm{n}=10$ ), 8-spored, bitunicate, clavate to ellipsoid, subsessile or sessile. Ascospores $15-22 \times 5$ $7 \mu \mathrm{m}(\overline{\mathrm{x}}=19 \times 6 \mu \mathrm{m}, \mathrm{n}=10)$, overlapping bi-seriate or multi-seriate, oblong-clavate, hyaline, 1-septate, constricted at the septum, thick-walled, smooth-walled, without a mucilaginous sheath. Asexual morph: Undetermined.

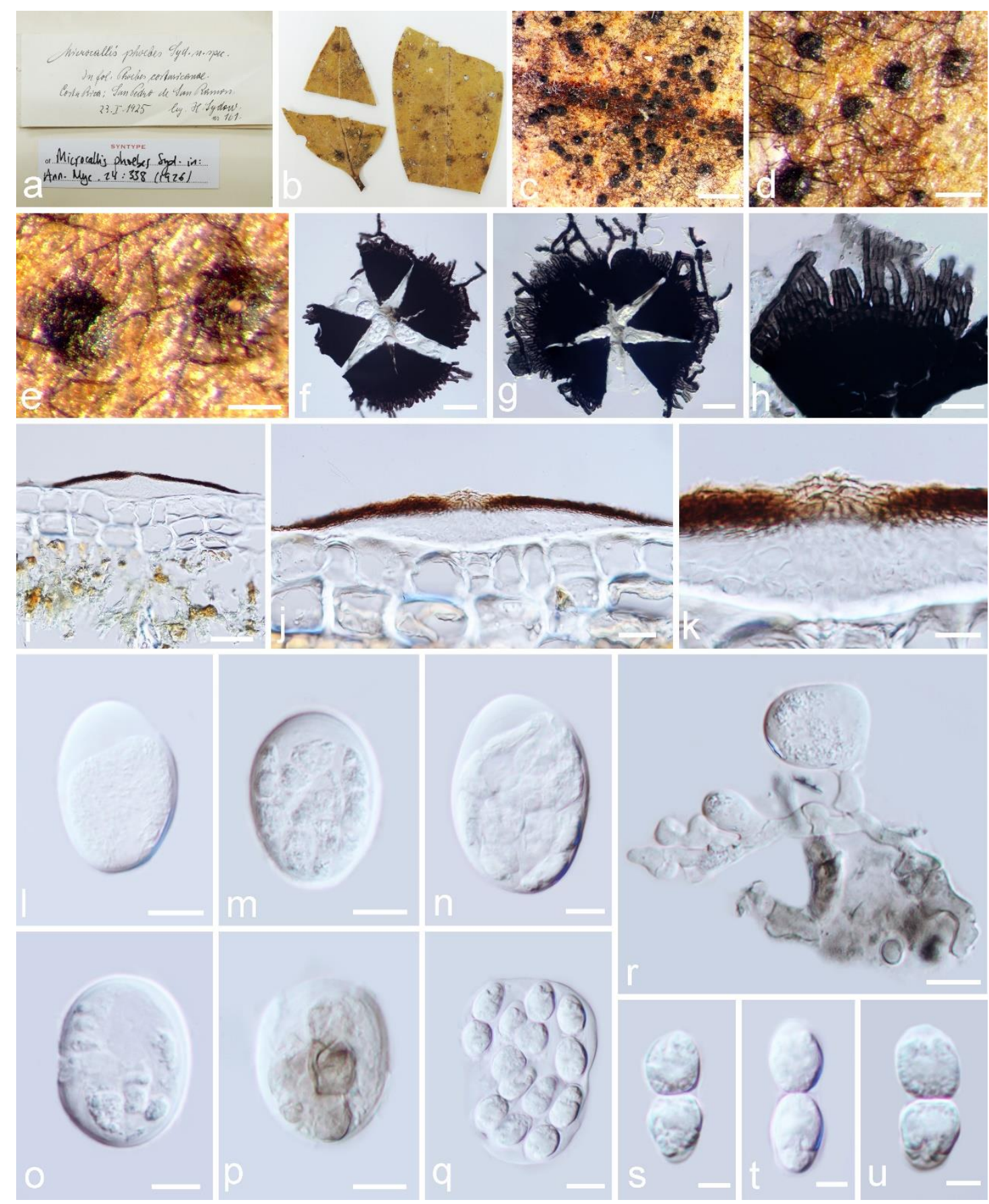

Figure 46 - Microcallis phoebes (E00429570, syntype). a Envelop and collection information of Microcallis phoebes. b Herbarium material. c-e Ascomata on the host surface. $\mathrm{f}-\mathrm{h}$ Squash mount of ascoma. Note upper wall of radiating cells at the margin. $\mathrm{i}-\mathrm{k}$ Vertical section of ascoma. 1-r Asci. 
s-u Ascospores. Scale bars: $\mathrm{c}=1000 \mu \mathrm{m}, \mathrm{d}=200 \mu \mathrm{m}, \mathrm{e}=100 \mu \mathrm{m}, \mathrm{f}, \mathrm{g}, \mathrm{i}=50 \mu \mathrm{m}, \mathrm{h}, \mathrm{j}=20 \mu \mathrm{m}, \mathrm{k}-\mathrm{r}=$ $10 \mu \mathrm{m}, \mathrm{s}-\mathrm{u}=5 \mu \mathrm{m}$.

Material examined - Costa Rica, San Pedro de San Ramon, on leaves of Phoebe sp. (Lauraceae), 23 January 1925, H. Sydow (E00429570, syntype).

Yatesula Syd. \& P. Syd., Annls mycol. 15(3/4): 237 (1917)

Index Fungorum number: IF5858, Facesoffungi number: FoF 10350; 2 morphological species (Species Fungorum 2021), molecular data unavailable.

Saprobic on leaves in terrestrial habitats. Mycelium lacking. Sexual morph: Ascomata superficial, gregarious, or some solitary, slightly raised, circular, black, coriaceous. Wall of ascoma thick at the apex and thin at the base, single layer, comprising pigmented, thick-walled cells. Hamathecium lacking paraphyses. Asci mainly 4-8-spored, bitunicate, fissitunicate, dehiscence not observed, obclavate to cylindrical, with short pedicel, ocular chamber not observed. Ascospores overlapping 2-3-seriate, oblong, fusiform to clavate, hyaline, slightly yellowish-brown, straight or curved, 1-4-septate, constricted at the septa, straight or slightly curved, smooth-walled, with a gelatinous sheath. Asexual morph: Undetermined.

Type species - Yatesula calami Syd. \& P. Syd.

Notes - Yatesula Syd. \& P. Syd. is characterized by circular, coriaceous ascomata with superficial mycelium, bitunicate, obclavate to cylindrical asci and oblong, fusiform to clavate, 1-4septate ascospores with a gelatinous sheath. Yatesula lacks setae and periphyses (Sydow \& Sydow 1917, Pereira-Carvalho et al. 2009). The obclavate to cylindrical asci and fusiform to clavate, hyaline, 1-4-septate ascospores are more typical of Dothideomycetes in Mycosphaerellaceae Lindau. However, the ascomata lack trabeculate pseudoparaphyses (sensu Liew et al. 2000) which excludes Yatesula from this family and order. We, therefore, exclude this genus pending fresh collection and DNA sequence data.

Yatesula calami Syd. \& P. Syd., Annls mycol. 15(3/4): 237 (1917)

Fig. 47

Index Fungorum number: IF248195; Facesoffungi number: FoF 10351

Sapribic on leaves of Calamus sp. in terrestrial habitats. Mycelium lacking. Sexual morph: Ascomata 170-220 $\mu \mathrm{m}$ diam. ( $\mathrm{x}=205 \mu \mathrm{m}, \mathrm{n}=10)$, superficial, gregarious, or some solitary, slightly raised, circular, black, coriaceous. Wall of ascoma 18-25 $\mu \mathrm{m}$ wide, thick at the apex and thin at the base, single layer, comprising pigmented, thick-walled cells. Hamathecium lacking paraphyses. Asci 37-55 $\times 8-15 \mu \mathrm{m}(\overline{\mathrm{x}}=45 \times 9 \mu \mathrm{m}, \mathrm{n}=10)$, mainly 8-spored, bitunicate, fissitunicate, dehiscence not observed, obclavate to cylindrical, with short pedicel, ocular chamber not observed. Ascospores 12-16 $\times 3-5 \mu \mathrm{m}(\overline{\mathrm{x}}=14 \times 4 \mu \mathrm{m}, \mathrm{n}=10)$, overlapping 2-3-seriate, fusiform to clavate, hyaline, straight or curved, 1-4-septate, constricted at the septa, smooth-walled, with a gelatinous sheath. Asexual morph: Undetermined.

Material examined - Philippines, Province of Rizal, Luzon, on leaves of Calamus sp. (Arecaceae), September 1915, H. S. Yates (S F5690, holotype).

\section{Discussion}

In this paper, we have revisited most genera of Chaetothyriales listed in Wijayawardene et al. (2020). Examination of herbarium specimens, morphology and phylogenetic analyses are used to revise and discuss placements of genera and the new classification is listed at the beginning of the results. The outcomes of this work are an updated account of Chaetothyriales and a basis for future work.

Chaetothyriales comprises a rich variety of asexual morphs, with only a few (16) sexual morphs found in the sooty mould families, viz., Chaetothyriaceae, Coccodiniaceae, Trichomeriaceae and lichenized families viz., Microtheliopsidaceae and Pyrenotrichaceae. Asexual genera of Chaetothyriales are dispersed in the monotypic families Cyphellophoraceae, Epibryaceae, Herpotrichiellaceae, Lyrommataceae, Paracladophialophoraceae and Trichomeriaceae, of which only 

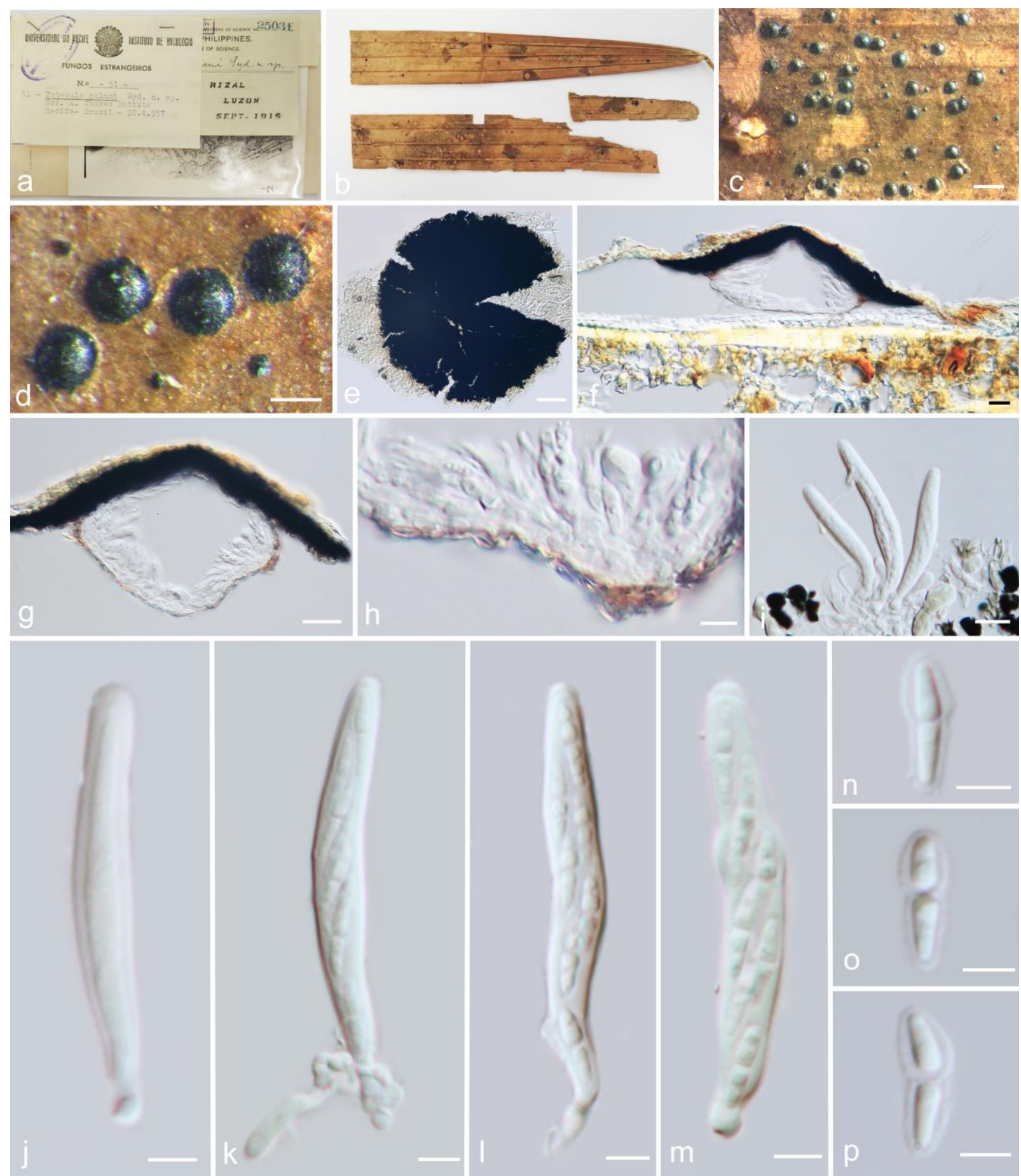

Figure 47 - Yatesula calami (S-F5690, holotype). a Envelop and collection information of Yatesula calami. b Herbarium specimen. c, d Appearance of black ascomata on the host. e Squash mount of ascoma. f, g Section of ascomata. h Vertical section through ascoma wall. i-m Asci with ascospores. $\mathrm{n}-\mathrm{p}$ Ascospores. Scale bars: $\mathrm{c}=500 \mu \mathrm{m}, \mathrm{d}=200 \mu \mathrm{m}, \mathrm{e}=50 \mu \mathrm{m}, \mathrm{f}-\mathrm{g}=20 \mu \mathrm{m}, \mathrm{h}, \mathrm{j}-\mathrm{p}=5 \mu \mathrm{m}, \mathrm{i}=10$ $\mu \mathrm{m}$.

Vonarxia in Chaetothyriaceae and Lyromma in Lyrommataceae are coelomycetous with pycnidial conidiomata with subulate setae. Others are hyphomycetous with a variety of morphological characteristics of asexual conidiogenous structures and mostly filiform or globose conidia. Asexually typified genera in Herpotrichiellaceae are mostly yeast-like species with acrogenous conidia adheringin chains and integrated yeast-like budding cells. Sexual morphs of Chaetothyriales species have dark, globose to subglobose and setose ascomata colonizing the surface of living leaves with mycelium appressed to the plant cuticle without penetrating host tissues. Ascomata of Beelia, 
Ceramothyrium, Ceratocarpia, Chaetothyriomyces, Phaeosaccardinula and Pyrenothrix have a smooth surface, without setae. The hamathecium is aparaphysate or has pseudoparaphyses embedded in a gelatinous matrix, but some species in Chaetothyriales, such as Actinocymbe, Coccodinium and Herpotrichiella have internally ostioles lined with periphyses. von Arx \& Müller (1975) stated that periphyses should be illustrated as an important character to identify species in Chaetothyriaceae. However, as more genera were accepted in Chaetothyriaceae, this seems to have become less important. The asci of Chaethothytiales are bitunicate, broadly clavate, mostly short pedicellate, and contain hyaline, aseptate to multi-septate or muriform ascospores. Therefore, the key characters to identify species in Chaetothyriales are setose ascomata with mycelium appressed to the host tissues, lack of hamathecium, bitunicate, short pedicellate asci, and hyaline, aseptate to multiseptate or muriform ascospores. Black yeast-like, cyphellophora-like, phialophora-like and cladophialophora-like species are also considered as Chaethothyriales but need phylogenetic analyses.

Common genera of sooty moulds occur with sap-feeding insects, such as aphids, whiteflies, soft scales, mealy bugs, leafhoppers and psyllids on the surface of leaves (Barr 1987, Chomnunti et al. 2014). The sooty mould members in Chaetothyriales are fairly harmless saprobes living on honeydew, but reduce plant photosynthesis, therefore, they cannot be considered as a true pathogen. Whether there is obligate symbiosis between the fungi, plants and insects are one of the research questions that need to be answered in future studies. Members of Epibryaceae and Trichomeriaceae are often rock colonizers while Trichomeriaceae are also sooty moulds on plant leaves that appear to grow in extreme environments and may be xerophilic. Xerophilic organisms may have biotechnological potential in enzyme production or bioremediation, while any novel antibiotics will have medical potential (Pickard et al. 1991, Faull et al. 2002, Herath et al. 2012).

The order as a whole is poorly studied and future studies are needed to collect species throughout the order and provide new sequence data to modify the understanding of the group. Quan et al. (2020) published an ecological appraisal of the group. The present study deals with classification and does not add to the ecological account, thus the ecology is not discussed further here. Saxena et al. (2021) indicated that Phialophoronites has similar spore-bearing bodies of Phialophora, with the species P. magnus evolved from Miocene (Neyveli Lignite) which is approximately equal to 25-05 MYA. Quan et al. (2020) included Meliola centellae, Cordyceps agriota, and Colletotrichum agaves-caricis in Sordariomycetes and species in Capnodiales as a calibration point, and concluded that Chaetothyriales evolved 387 MYA (end of Devonian). The order has existed for a very long time and numerous genera and species are likely to have evolved. Speciation events occurred in 201-145 MYA (Jurassic). In future work, the first species Phialophoronites magnus should be included to provide divergency times for Chaetothyriales.

The order Chaetothyriales presently contains ten families, 55 genera and 667 species, although most sexual morphs of Chaetothyriales lack molecular data. Of the 55 genera, almost half (24 genera) comprise only one or two species. This is likely to reflect the lack of collection and studies in the group, since many are tropical genera (Hyde et al. 2020). We do not believe these genera comprise so few species and expect that future studies will increase the numbers of taxa in the genera significantly and reveal new genera and possibly families.

\section{Acknowledgements}

We thank Thailand Science Research and Innovation (TSRI) grant "Macrofungi diversity research from the Lancang-Mekong Watershed and Surrounding areas (grant no. DBG6280009). The Mushroom Research Foundation, Chiang Rai, Thailand is thanked for supporting this research. K.D. Hyde thanks Chiang Mai University for the award of Visiting Professor. Kevin D. Hyde thanks the Chinese Academy of Sciences, project number 2013T2S0030, for the award of Visiting Professorship for Senior International Scientists at Kunming Institute of Botany. Qing Tian and Putarak Chomnunti thank the grant of the Thailand Research Foundation (TRG5780008) for supporting studies on sooty moulds and the National Research Council of Thailand (grant for Dothideomycetes No: 58201020010) for supporting studies on Dothideomycetes. 


\section{References}

Arzanlou M, Crous PW. 2006 - Strelitziana africana M. Arzanlou \& Crous, gen. and sp. nov. Fungal Planet. no. 8. 2 pp.

Aa HA van der, Arx JA von. 1986 - On Vonarxia, Kazulia and other fungi with stauroconidia. Persoonia 13, 127-128.

Aa HA van der, Oorschot CAN van. 1985 - A redescription of some genera with staurospores. Persoonia 12, 415-425.

Ajello L, Padhye AA, Payne M. 1980 - Phaeohyphomycosis in a dog caused by Pseudomicrodochium suttonii sp. nov. Mycotaxon 12, 131-136.

Ali T, Schmuker A, Runge F, Solovyeva I et al. 2016 - Morphology, phylogeny, and taxonomy of Microthlaspi (Brassicaceae: Coluteocarpeae) and related genera. Taxon 65(1), 79-98.

Al-Tawfiq JA, Amr SS. 2009 - Madura leg due to Exophiala jeanselmei successfully treated with surgery and itraconazole therapy. Medical Mycology 47, 648-652.

Ando K, Tubaki K. 1985 - Three new hyphomycetes from Japan: Anthopsis microspora, Scutisporus brunneus, and Titaeella capnophila. Transactions of the Mycological Society of Japan 26, 151-160.

Arnaud, G. 1930 - Les Asterinées. V. Ann. Epiphyt. 16: 235 -302.

Arzanlou M, Groenewald JZ, Fullerton RA, Abeln ECA et al. 2008 - Multiple gene genealogies and phenotypic characters differentiate several novel species of Mycosphaerella and related anamorphs on banana. Persoonia 20, 19-37.

Arzanlou M, Groenewald JZ, Gams W, Braun U et al. 2007 - Phylogenetic and morphotaxonomic revision of Ramichloridium and allied genera. Studies in Mycology 58, 57-93.

Auclair JL. 1963 - Aphid feeding and nutrition. Annual Review of Entomology 8, 439-490.

Ávila A, Groenewald JZ, Trapero A, Crous PW. 2005 - Characterisation and epitypification of Pseudocercospora cladosporioides, the causal organism of Cercospora leaf spot of olives. Mycological Research 109, 881-888.

Badali H, Bonifaz A, Barrón-Tapia T, Vázquez-González D et al. 2010 - Rhinocladiella aquaspersa, proven agent of verrucous skin infection and a novel type of chromoblastomycosis. Medical Mycology 48(5), 696-703.

Badali H, Carvalho VO, Vicente V, Attili-Angelis D et al. 2009 - Cladophialophora saturnica sp. nov., a new opportunistic species of Chaetothyriales revealed using molecular data. Medical Mycology 47, 51-66.

Badali H, Gueidan C, Najafzadeh MJ, Bonifaz A et al. 2008 - Biodiversity of the genus Cladophialophora. Studies in Mycology 61, 175-191.

Badali H, Prenafeta-Boldú FX, Guarro J, Klaassen CH et al. 2011 - Cladophialophora psammophila, a novel species of Chaetothyriales with a potential use in the bioremediation of volatile aromatic hydrocarbons. Fungal Biologyogy 115, 1019-1029.

Barr ME. 1987 - Prodromus to class Loculoascomycetes. University of Massachusetts, Amherst.

Barr ME. 1991 - Notes on and additions to North-American members of the Herpotrichiellaceae. Mycotaxon 41, 419-436.

Barr ME. 1976 - Perspectives in the Ascomycotina. Memoirs of the New York Botanical Garden 28, 1-8.

Barr ME. 1979 - A classification of Loculoascomycetes. Mycologia 71, 935-957.

Batista AC, Ciferri R. 1957 - Morphogenesis and systematics of the fungi of the new order Chaetothyriales. Anais da Sociedade de Biologia de Pernambuco 15, 283 -295.

Batista AC. 1960 - Lembopodia, Yamamotoa e Peresiopsis, novos gêneros de Asterinaceae. Publicações. Instituto de Micologia da Universidade do Recife 291, 1-35.

Batista AC, Ciferri R. 1962 - The Chaetothyriales. Sydowia 3, 1-129.

Batista AC, Ciferri R. 1963 - The sooty-molds of the family Asbolisiaceae. Quaderni. Laboratorio Crittogamico, Istituto Botanico della Università di Pavia 31(7), 229. 
Batista AC, Cavalcante W de A, Peres GP. 1967 - Novas espécies de Microthyriaceae. Atas do Instituto de Micologia da Universidade do Recife 5, 213-224.

Berbee ML. 1996 - Loculoascomycetes origins and evolution of filamentous ascomycete morpholology based on 18A rRNA gene sequence data. Molecular Biology and Evolution 13, $462-470$.

Bigelow H E, Barr ME. 1963 - Contribution to the fungus flora of northeastern North America. III. Rhodora 65, 289-309.

Borelli D. 1980 - Causal agents of chromoblastomycosis (Chromomycetes). Proceedings of the 5th International Conference on Mycoses pp. 335-340.

Bukovská P, Jelínková M, Hršelová H, Sýkorová Z et al. 2010 - Terminal restriction fragment length measurement errors are affected mainly by fragment length, $\mathrm{G}+\mathrm{C}$ nucleotide content and secondary structure melting point. Journal of Microbiological Methods 82, 223-228.

Cai L, Ji KF, Hyde KD. 2006 - Variation between freshwater and terrestrial fungal communities on decaying bamboo culms. Antonie Van Leeuwenhoek 89, 293-301.

Cao F, Zhou J, Xu KX, Zhang MQ et al. 2013 - New cembranoid diterpene from the South China Sea soft coral Sarcophyton sp. Natural Product Communications 8, 1675-1678.

Caretta G, Tosi S, Piontelli E, de Hoog GS. 2006 - Phialophora sessilis, a lithobiont fungus. Mycotaxon 95, 281-284.

Carmichael JW. 1966 - Cerebral mycetoma of trout due to a Phialophora-like fungus. Sabouraudia $5(1), 120-123$.

Castañeda-Ruiz RF, Guarro J, Velásquez-Noa S, Gené J. 2003 - A new species of Minimelanolocus and some hyphomycete records from rain forests in Brazil. Mycotaxon 85, 231-239.

Chen KH, Miadlikowska J, Molnar K, Arnold AE et al. 2015 - Phylogenetic analyses of eurotiomycetous endophytes reveal their close affinities to Chaetothyriales, Eurotiales, and a new order - Phaeomoniellales. Molecular Phylogenetics and Evolution 85, 117-130.

Chomnunti P, Bhat DJ, Jones EBG, Chukeatirote E et al. 2012b - Trichomeriaceae, a new sooty mould family of Chaetothyriales. Fungal Diversity 56, 63-76.

Chomnunti P, Hongsanan S, Aguirre-hudson B, Tian Q et al. 2014 - The sooty moulds. Fungal Diversity 66, 1-36.

Chomnunti P, Koko TW, Chukeatirote E, Cai L et al. 2012a - Phylogeny of Chaetothyriaceae in northern Thailand including three new species. Mycologia 104, 382-395.

Chomnunti P, Schoch CL, Aguirre-Hudson B, Ko TWK et al. 2011 - Capnodiaceae. Fungal Diversity $51,103-134$.

Ciferri R, Montemartini A. 1957 - Sui generi Muchmoria Sacc. e Veronaea n.gen. (Dematiaceae, Didymosporae). Atti dell'Istituto Botanico della Università e Laboratorio Crittogamico di Pavia 15, 67-72.

Cooke MC. 1871 - Handbook of British fungi. Vol 2. MacMillan and Co., London, p 492.

Crous PW, Braun U, Wingfield MJ, et al. 2009 - Phylogeny and taxonomy of obscure genera of microfungi. Persoonia-Molecular Phylogeny and Evolution of Fungi 22, 139-161.

Crous PW, Schroers HJ, Groenewald JZ, Braun U et al. 2006 - Metulocladosporiella gen. nov. for the causal organism of Cladosporium speckle disease of banana. Mycological Research 110, 264-275.

Crous PW, Schubert K, Braun U, de Hoog GS et al. 2007 - Opportunistic, human-pathogenic species in the Herpotrichiellaceae are phenotypically similar to saprobic or phytopathogenic species in the Venturiaceae. Studies in Mycology 58, 185-217.

Crous PW, Schumacher RK, Akulov A, Thangavel R et al. 2019b - New and interesting fungi 2. Fungal Systematics and Evolution 3, 57-134.

Crous PW, Schumacher RK, Wingfield MJ, Lombard L et al. 2015b - Fungal systematics and evolution: FUSE 1. Sydowia -Horn- 67, 81-118.

Crous PW, Wingfield MJ, Guarro J, Cheewangkoon R et al. 2013 - Fungal Planet description sheets: 154-213. Persoonia: Molecular Phylogeny and Evolution of Fungi 31, 188-296. 
Crous PW, Summerell BA, Shivas RG, Burgess TI et al. 2012 - Fungal Planet description sheets: 107-127. Persoonia 28, 138-182.

Crous PW, Wingfield MJ, Le Roux JJ, Richardson DM et al. 2015a - Fungal Planet Description Sheets: 371-399. Persoonia 35, 264-327.

Crous PW, Wingfield MJ, Burgess TI, Hardy GEStJ et al. 2016 - Fungal Planet description sheets: 469-557. Persoonia 37, 218-403.

Crous PW, Wingfield MJ, Burgess TI, Hardy GEStJ et al. 2018 - Fungal Planet description sheets: 716-784. Persoonia 40, 240-393.

Crous PW, Wingfield MJ, Lombard L, Roets F et al. 2019a - Fungal Planet description sheets: 951-1041. Persoonia 43, 223-425.

Darmostuk VV, Khodosovtsev AY. 2019 - Epibryon kondratyukii sp. nov., a new algicolous fungus, and notes on rare lichenicolous fungi collected in Southern Ukraine. Folia Cryptogamica Estonica 56, 109-116.

de Filho JPL, Paiva ÉAS. 2006 - The effects of sooty mold on photosynthesis andmesophyll structure of mahogany (Swieteniamacrophylla King., Meliaceae). Bragantia 65(1), 11-17.

de Hoog GS, Guarro J, Gené J, Figueras MJ. 2000a - Atlas of Clinical Fungi, 2nd ed. Centraalbureau voor Schimmelcultures, Utrecht, Universitat Rovira i Virgili, Reus.

de Hoog GS, Guého E, Masclaux F, Gerrits van den Ende AHG et al. 1995 - Nutritional physiology and taxonomy of human-pathogenic Cladosporium-Xylohypha species. Journal of Medical \& Veterinary Mycology 33, 339-347.

de Hoog GS, Hermanides-Nijhof EJ. 1977 - The black yeasts and allied Hyphomycetes. Studies in Mycology 15, 1-222.

de Hoog GS, Nishikaku AS, Fernández Zeppenfeldt G, Padín-González C et al. 2007 - Molecular analysis and pathogenicity of the Cladophialophora carrionii complex, with the description of a novel species. Studies in Mycology 58, 219-234.

de Hoog GS, Vicente VA, Najafzadeh M, Harrak M et al. 2011 - Waterborne Exophiala species causing disease in cold-blooded animals. Persoonia 27, 46-72.

de Hoog GS, Mayser P, Haase G, Horré R et al. 2000b - A new species, Phialophora europaea, causing superficial infections in humans. Mycoses 43, 409-416.

de Hoog GS, Zalar P, Urzi C, de Leo F et al. 1999 - Relationships of dothideaceous black yeasts and meristematic fungi based on 5.8S and ITS2 rDNA sequence comparison. Studies in Mycology 43, 31-37.

de Vries GA. 1962 - Cyphellophora laciniata nov. gen., nov. sp., and Dactylium fusarioides Fragoso et Ciferri. Mycopathologia et mycologia applicata 16, 47-54.

Decock C, Celgado-Rodriguez G, Buchet S, Seng JM. 2003 - A new species and three new combination in Cyphellophora, with a note on the taxonomic affinities of the genus, and its relation to Kumbhamaya and Pseudomicrodochium. Antonie van Leewenhoek 84, 209-216.

Defossez E, Dubois MP, Mondolot L, Faccio A et al. 2009 - Ant-plants and fungi: a new three-way symbiosis. New Phytologist 1978, 942-949.

Del Prado R, Schmitt I, Kautz S, Palice Z et al. 2006 - Molecular data place Trypetheliaceae in Dothideomycetes. Mycological Research 110, 511-520.

Diederich P. 2010 - Sclerococcum cladoniae, a new lichenicolous hyphomycete on Cladonia from Luxembourg. Bulletin de la Société des naturalistes luxembourgeois 111, 57-59.

Diederich P, Ertz D, Lawrey JD, Sikaroodi M et al. 2013 - Molecular data place the hyphomycetous lichenicolous genus Sclerococcum close to Dactylospora (Eurotiomycetes) and S. parmeliae in Cladophialophora (Chaetothyriales). Fungal Diversity 58, 61-72.

Döbbeler P. 1978 - Moosbewohnende Ascomyceten I. Die pyrenocarpen, den Gametophyten besiedelnden Arten. Mitt Bot München 14, 1- 360.

Döbbeler P. 2016 - Three new ascomycetes on epiphyllous liverworts. Karstenia. 56(1/2), 47-54.

Dong W, Hyde KD, Bhat DJ, Zhang H. 2018 - Introducing Aculeata aquatica gen. et sp. nov., Minimelanolocus thailandensis sp. nov. and Thysanorea aquatica sp. nov. 
(Herpotrichiellaceae, Chaetothyriales) from fresh water in northern Thailand. Mycological Progress 17, 617-629.

Ellis MB. 1971 - Dematiaceous hyphomycetes. Commonwealth Mycological Institute, Kew, England.

Eriksson OE. 1981 - The families of bitunicate ascomycetes. Nordic Journal of Botany 1(6), 800.

Eriksson OE. 1982 - Revision of "Outline of the Ascomycetes". Syst Ascom 1, 1-16.

Eriksson OE. 2006 - Outline of Ascomycota-2006. Myconet 12, 1-82.

Eriksson OE, Baral HO, Currah RS, Hansen K, et al. 2004 - Outline of Ascomycota-2004. Myconet 10(1), 89.

Faull JL, Olejnik I, Ingrouille M, Reynolds D. 2002 - A reassessment of the taxonomy of some tropical sooty moulds. Tropical Mycology 2, 33-40.

Feng P, Lu Q, Najafzadeh MJ, van den Ende AG et al. 2012 - Cyphellophora and its relatives in Phialophora: biodiversity and possible role in human infection. Fungal Diversity 65, 17-45.

Feng P, Lu Q, Najafzadeh MJ, van den Ende AG et al. 2014 - Cyphellophora and its relatives in Phialophora: biodiversity and possible role in human infection. Fungal Diversity 65, 17-45.

Ferrari BC, Zhang C, van Dorst J. 2011 - Recovering greater fungal diversity from pristine and diesel fuel contaminated sub-Antarctic soil through cultivation using both a high and a low nutrient media approach. Frontiers in Microbiology 2, 217.

Fisher EE. 1939 - A study of Australian 'sooty moulds'. Annals of Botany (London) New Series 3, 399-426.

Flakus A, Farkas E. 2013 - A contribution to the taxonomy of Lyromma (Lyrommataceae, lichenized Ascomycota) with a species key. Mycotaxon 124, 127-141.

Fraser L. 1935 - An investigation of the sooty moulds of New South Wales. V. The species of the Chaetothyrieae. Proceedings of the Linnean Society of New South Wales 60, 280-290.

Fries EM. 1849 - Summa vegetabilium Scandinaviae 2, 259-572.

Gams W, Holubová-Jechová V. 1976 - Chloridium and some other dematiaceous hyphomycetes growing on decaying wood. Studies in Mycology 13, 1-99.

Gao L, Ma Y, Zhao W, Wei Z et al. 2015 - Three New Species of Cyphellophora (Chaetothyriales) Associated with Sooty Blotch and Flyspeck. PLoS One 10, e0136857.

Geiser DM, Gueidan C, Miadlikowska J, Lutzoni F et al. 2006 - Eurotiomycetes: Eurotiomycetidae and Chaetothyriomycetidae. Mycologia 98, 1054-1065.

Gezuele E, Mackinnon JE, Conti-Diaz IA. 1972 - The frequent isolation of Phialophora verrucosa and Fonsecaea pedrosoi from natural sources. Sabouraudia 10, 266-273.

Gleason ML, Batzer JC, Sun GY, Zhang R et al. 2011 - A new view of sooty blotch and flyspeck. Plant Disease 95, 368-383.

Gomes RR, Vicente VA, Azevedo CMd, Salgado CG et al. 2016 - Molecular epidemiology of agents of human chromoblastomycosis in Brazil with the description of two novel species. PLOS Neglected Tropical Diseases 10(11), e0005102.

González GM, Rojas OC, González JG, Kang Y et al. 2013 - Chromoblastomycosis caused by Rhinocladiella aquaspersa. Medical mycology case reports 2, 148-51.

Gueidan C, Aptroot A, da Silva Cáceres ME, Badali H et al. 2014 - A reappraisal of orders and families within the subclass Chaetothyriomycetidae (Eurotiomycetes, Ascomycota). Mycological Progress 13, 1027-1039.

Gueidan C, Villaseñor CR, de Hoog GS, Gorbushina WA et al. 2008 - A rock-inhabiting ancestor for mutualistic and pathogen-rich fungal lineages. Studies in Mycology 61, 111-119.

Haase G, Sonntag L, Melzer-Krick B, De Hoog GS. 1999 - Phylogenetic inference by SSU-gene analysis of members of the Herpotrichiellaceae with special reference to human pathogenic species. Studies in Mycology 43, 80-97.

Halıcı MG, Akata I, Kocakaya M. 2010 - New records of lichenized and lichenicolous fungi from Turkey. Mycotaxon 114, 311-314.

Hall TA. 1999 - BioEdit: a user-friendly biological sequence alignmenteditor and analysis program for Windows 95/98/NT. Nucleic Acids Symposium Series 95-98. 
Hansford CG. 1946 - The foliicolous ascomycetes, their parasites and associated fungi. Mycological Papers 15, 1-240.

Harrington TC, Mcnew DL. 2003 - Phylogenetic analysis places the Phialophora-like anamorph genus Cladophora in the Helotiales. Mycotaxon 87, 141-151.

Hawksworth DL, Kirk PM, Sutton BC, Pegler DN. 1995 - Ainsworth and Bisby's Dictionary of the Fungi, $8^{\text {th }}$ edn. CAB International, Wallingford, U.K.

Hawksworth DL, Eriksson O. 1987 - Notes on ascomycete systematics. Nos 225-463. Systema Ascomycetum 6, 111-165.

Hawksworth DL, Dyko BJ. 1979 - Lichenodiplis and Vouauxiomyces: two new genera of lichenicolous Coelomycetes. The Lichenologist 11(1), 51-61.

He F, Lin B, Sun JZ, Liu XZ. 2013 - Knufia aspidiotus sp. nov., a new black yeast from scale insects. Phytotaxa 153(1), 39-50.

Hawksworth DL, Dyko BJ. 1979 - Lichenodiplis and Vouauxiomyces: two new genera of lichenicolous coelomycetes. Lichenologist 11: 51-61.

Henssen A. 1964 - Was ist Pyrenothrix nigra? Ber Deutsch Bot Gesell 77, 317-322.

Herath K, Jayasuriya H, Zink DL, Sigmund J et al. 2012 - Isolation, structure elucidation, and antibacterial activity of methiosetin, a tetramic acid from a tropical sooty mold (Capnodium sp.). Journal of Natural Products 75(3), 420-424.

Hernández-Restrepo M, Castañeda-Ruiz RF, Gené J, Guarro J et al. 2013 - Microfungi from Portugal: Minimelanolocus manifestus sp. nov. and Vermiculariopsiella pediculata comb. nov. Mycotaxon 122(1), 135-143.

Hernandez-Restrepo M, Schumacher RK, Wingfield MJ, Ahmad I et al. 2016 - Fungal systematics and evolution: FUSE 2.

Hernández-Restrepo M, Giraldo A, van Doorn R, Wingfield MJ et al. 2020 - The Genera of FungiG6: Arthrographis, Kramasamuha, Melnikomyces, Thysanorea, and Verruconis. Fungal Systematics and Evolution 6, 1-24.

Herrera-Campos MDLA, Huhndorf S, Lücking R. 2005 - The foliicolous lichen flora of Mexico IV: a new, foliicolous species of Pyrenothrix (Chaetothyriales: Pyrenothrichaceae). Mycologia 97, 356-61.

Hofmann TA, Piepenbring M. 2006 - New records and host plants of fly-speck fungi from Panama. Fungal Diversity 22, 55-70.

Hongsanan S, Hyde KD, Bahkali AH, Camporesi E et al. 2015 - Fungal Biodiversity Profiles 1120. Cryptogamie, Mycologie 36, 355-380.

Hongsanan S, Tian Q, Hyde KD, Hu DM. 2016 - The asexual morph of Trichomerium gloeosporum. Mycosphere 7, 1473-1479.

Hubka V, Réblová M, Řehulka J, Selbmann L et al. 2014 - Bradymyces gen. nov. (Chaetothyriales, Trichomeriaceae), a new ascomycete genus accommodating poorly differentiated melanized fungi. Antonie van Leeuwenhoek 106, 979-992.

Hubka V, Réblová M, Řehulka J, Selbmann L et al. 2014 - Bradymyces gen. nov. (Chaetothyriales, Trichomeriaceae), a new ascomycete genus accommodating poorly differentiated melanized fungi, B. oncorhynchi sp. nov. and B. alpinus sp. nov. Antonie van Leeuwenhoek 106(5), 979-992.

Huelsenbeck JP, Ronqvist F. 2001 - MrBAYES: Bayesian inference of phylogeny. Bioinformatics 17, 754-755.

Hughes SJ. 1976 - Sooty moulds. Mycologia 68(4), 693-820.

Hughes SJ. 1983 - New Zealand fungi. 32. Janetia capnophila sp. nov. and some allies. New Zealand Journal of Botany 21(2), 177-182.

Hutchison LJ, Untereiner WA, Hiratsuka Y. 1995 - Knufia cryptophialidica gen. et sp. nov., a dematiaceous hyphomycete isolated from black galls of trembling aspen (Populus tremuloides). Mycologia 87(6), 902-908.

Hyde KD, Jones EBG, Liu JK, Ariyawansa HA et al. 2013 - Families of Dothideomycetes. Fungal Diversity 63, 1-313. 
Hyde KD, McKenzie EHC, KoKo TW. 2011 - Towards incorporating anamorphic fungi in a natural classification - checklist and notes for 2010. Mycosphere 2, 1-88.

Isola D, Selbmann L, de Hoog GS, Fenice M et al. 2013 - Isolation and screening of black fungi as degraders of volatile aromatic hydrocarbons. Mycopathologia, 175(5-6), 369-379.

Isola D, Zucconi L, Onofri S, Caneva G et al. 2016 - Extremotolerant rock inhabiting black fungi from Italian monumental sites. Fungal Diversity 76, 75-96.

Iwatsu T. 1984 - A new species of Cladosporium from Japan. Mycotaxon 20, 521-533.

Katoh K, Standley DM. 2013 - MAFFT multiple sequence alignment software version 7: improvements in performance and usability. Molecular Biology and Evolution 30, 772-780 (outlines version 7).

Kirk PM, Cannon PF, Minter DW, Staplers JA. 2008 - Dictionary of the fungi, 10th edn. CABI Bioscience, UK.

Klaubauf S., Tharreau D., Fournier E., Groenewald J.Z et al. 2014 - Resolving the polyphyletic nature of Pyricularia (Pyriculariaceae). Studies in Mycology 79, 85-120.

Koo S, Klompas M, Marty FM. 2010 - Fonsecaea monophora cerebral phaeohyphomycosis: case report of successful surgical excision and voriconazole treatment and review. Medical Mycology 48, 769-74.

Laemmlen FF. 2011 - Sooty mold. integrated pest management for home gardeners and landscape professionals. Pest notes, University of California. Agriculture and Natural Resources, U.S.A., from http://www.ipm.ucdavis.edu/PDF/PESTNOTES/pnsootymold.pdf (Retrieved on November 12, 2012)

Lastoria C, Cascina A, Bini F, Di Matteo A et al. 2009 - Pulmonary Cladophialophora boppii infection in a lung transplant recipient: case report and literature review. The Journal of Heart and Lung Transplantation 28, 635-637.

Li HY, Sun GY, Batzer JC, Crous PW et al. 2011 - Scleroramularia gen. nov. associated with sooty blotch and flyspeck of apple and pawpaw from the Northern Hemisphere. Fungal Diversity 46, 53-66.

Li J, Jeewon R, Phookamsak R, Bhat DJ et al. 2018 - Marinophialophora garethjonesii gen. et sp. nov.: a new hyphomycete associated with Halocyphina from marine habitats in Thailand. Phytotaxa 345(1), 1-12.

Li YM, HaixiaWu, Cheng H, Hyde KD. 2011 - Morphological studies in Doithideomycetes: Elsinoë (Elsinoaceae), Butleria and three excluded genera. 115, 507-520.

Liew ECY, Aptroot A, Hyde KD. 2000 - Phylogenetic significance of the pseudoparaphyses in Loculoascomycete taxonomy. Molecular Phylogenetics and Evolution 16, 392-402.

Little AEF, Currie CR. 2007 - Symbiotic complexity: discovery of a fifth symbiont in the attine ant-microbe symbiosis. Biology Letters 3, 501-504.

Liu JK, Hyde KD, Gareth EBG, Ariyawansa HA et al. 2015 - Fungal Diversityity notes 1-110: Taxonomic and phylogenetic contributions to fungal species. Fungal Diversity 72, 1-197.

Liu JK, Hyde KD, Jeewon R, Phillips AJL et al. 2017 - Ranking higher taxa using divergence times: a case study in Dothideomycetes. Fungal Diversityity 84, 75-99.

Liu JK, Phookamsak R, Jones EBG, Zhang Y et al. 2011 - Astrosphaeriella is polyphyletic, with species in Fissuroma gen. nov., and Neoastrosphaeriella gen. nov. Fungal Diversity 51, 135154.

Liu YJ, Hall BD. 2004 - Body plan evolution of ascomycetes, as inferred from an RNA polymerase II phylogeny. Proceedings of the National Academy of Sciences USA 101, 4507-4512.

Liu XY, Udayanga D, Luo ZL, Chen LJ et al. 2015 - Backbone tree for Chaetothyriales with four new species of Minimelanolocus from aquatic habitats, Fungal Biology 119(11), 1046-1062.

Lopez M, Robinson S, Cooley A, Prichard M et al. 2007 - Molecular identification of Phialophora oxyspora as the cause of mycetoma in a horse. Journal of the American Veterinary Medical Association 230, 84-88.

Lücking R. 2008 - Foliicolous Lichenized Fungi. Flora Neotropica Monograph 103, 1- 866.

Lumbsch HT, Huhndorf SM. 2007 - Outline of ascomycota-2007. Myconet 13, 1-58. 
Lumbsch HT, Huhndorf SM. 2010 - Outline of ascomycota - 2009. Fieldiana Life and Earth Sciences 1, 1-60.

Lumbsch HT, Schmitt I, Lindemuth R, Miller A et al. 2005 - Performance of four ribosomal DNA regions to infer higher-level phylogenetic relationships of inoperculate euascomycetes (Leotiomycota). Molecular Phylogenetics and Evolution 34, 512-524.

Luttrell ES. 1973 - Loculoascomycetes. In The fungi, an advanced treatise. Vol. 4A. Edited by G. C. Ainsworth, F. K. Sparrow, and A. S. Sussman. Academic Press, New York and London. pp. 135-219.

Lutzoni F, Kauff F, Cox CJ, McLaughlin D et al. 2004 - Assembling the fungal tree of life: progress, classification, and evolution of subcellular traits. American Journal of Botany 91, 1446-1480.

Lutzoni F, Pagel M, Reeb V. 2001 - Major fungal lineages are derived from lichen symbiotic ancestors. Nature 41, 937-940.

Ma J, Ma LG, Zhang YD, Castañeda-Ruíz RF et al. 2011b - Pseudospiropes linderae sp. nov. and notes on Minimelanolocus (both anamorphic Strossmayeria) new to China. Nova Hedwigia 93(3-4), 465-473.

Ma J, Zhang YD, Ma LG, Zhang XG. 2011a - Two new Minimelanolocus species from southern China. Mycotaxon 117, 131-135.

Ma YR, Xia JW, Gao JM, Li XY et al. 2015 - Atrokylindriopsis, a new genus of hyphomycetes from Hainan, China, with relationship to Chaetothyriales. Mycological Progress 14, 77.

Maciá-Vicente JG, Glynou K, Piepenbring M. 2016 - A new species of Exophiala associated with roots. Mycological Progress 15, 18.

Madrid H, Hernández-Restrepo M, Gené J, Cano J et al. 2016 - New and interesting chaetothyrialean fungi from Spain. Mycological progress 15, 1179-1201.

Maharachchikumbura SSN, Haituk S, Pakdeeniti P, Al-Sadi AM et al. 2018 - Phaeosaccardinula coffeicola and Trichomerium chiangmaiensis, two new species of Chaetothyriales (Eurotiomycetes) from Thailand. Mycosphere 9, 769-778.

Marchisio VF, Fontana A, Mosca AML. 1977 - Anthopsis deltoidea, a new genus and species of Dematiaceae from soil. Canadian Journal of Botany 55(2), 115-117.

Massalongo AB. 1860 - Esame comparativo di alcune genere di licheni. Atti dell'Istituto Veneto Scienze. 5, 313-337.

Matos T, de Hoog GS, de Boer AG, De Crom I et al. 2002 - High prevalence of the neurotrope Exophiala dermatididis and related oligotrophic black yeasts in sauna facilities. Mycoses 45, 373-377.

Mayer VE, Volgmayr H. 2009 - Mycelial carton galleries of Azteca brevis (Formicidae) as a multispecies network. Proceedings of the Royal Society B: Biological Sciences 276, 3265-3273.

McGinnis MR, Lemon SM, Walker DH, de Hoog GS et al. 1999 - Fatal cerebritis caused by a new species of Cladophialophora. Studies in Mycology 43, 166-171.

Medlar EM. 1915 - A new fungus, Phialophora verrucosa, pathogenic for man. Mycologia 7(4), 200-203.

Mehrabi M, Asgari B, Hemmati R. 2018 - Knufia perfecta, a new black yeast from Iran, and a key to Knufia species. Nova Hedwigia 106(3-4), 519-534.

Melin E, Nannfeldt JA. 1934 - Researches into the blueing of ground woodpulp. Svenska Skogsvårdsföreningens Tidskrift 3-4, 397-616.

Mendoza L, Karuppayil SM, Szaniszlo PJ. 1993 - Calcium regulates in vitro dimorphism in chromoblastomycotic fungi. Mycoses 36, 157-164.

Miadlikowska J, Lutzoni F. 2004 - Phylogenetic classification of peltigeralean fungi (Peltigerales, Ascomycota) based on ribosomal RNA small and large subunits. American Journal of Botany 91, 449-464.

Miller AN, Huhndorf SM. 2004 - A natural classification of Lasiosphaeria based on nuclear LSU rDNA sequences. Mycological Research 108, 26-34. 
Miller AN, Huhndorf SM. 2005 - Multi-gene phylogenies indicate ascomal wall morphology is a better predictor of phylogenetic relationships than ascospore morphology in the Sordariales (Ascomycota, Fungi). Molecular Phylogenetics and Evolution 35, 60-75.

Mitchell DM, Fitz-Henley M, Horner-Bryce J. 1990 - A case of disseminated haeohyphomycosis caused by Cladosporium devriesii. The West Indian Medical Journal 39, 118-123.

Moreno-Rico O, Groenewald JZ, Crous PW. 2014 - Foliicolous fungi from Arctostaphylos pungens in Mexico. IMA Fungus 5, 7-15.

Morio F, Le Berre JY, Garcia-Hermoso D, Najafzadeh MJ et al. 2012 - Phaeohyphomycosis due to Exophiala xenobiotica as a cause of fungal arthritis in an HIV-infected patient. Medical Mycology 50, 513-517.

Moussa TA, Gerrits van den Ende BH, Al Zahrani HS, Kadasa NM et al. 2017 - The genus Anthopsis and its phylogenetic position in Chaetothyriales. Mycoses 60(4), 254-259.

Muggia L, Fleischhacker A, Kopun T, Grube M. 2016 - Extremotolerant fungi from alpine rock lichens and their phylogenetic relationships. Fungal Diversity 76, 119-142.

Muggia L, Quan Y, Gueidan C, Al-Hatmi AMS et al. 2020 - Ancestral Chaetothyriales with two novel lineages of lichen-associated fungi. Fungal Diversity (in press).

Müller E, Petrini O, Fisher PJ, Samuels GJ et al. 1987 - Taxonomy and anamorphs of the Herpotrichiellaceae with notes on generic synonomy. Transactions of the British Mycological Society 88, 63-74.

Muller E, von Arx JA 1962 - Die Galtungen der didymosporen Pyrenomyceten. Beitrage zur Kryptogamenflora der Schweiz 11, 1-922.

Muller E, Pehini O, Fisher PJ, Samuels GJ et al. 1987 - Taxonomy and anamorphs of the Herpotrichiellaceae with notes on generic synonymy. Transactions of the British Mycological Society $88,63-74$.

Munk A. 1957 - Danish pyrenomyctes. Dansk Botanisk Arkiv Udgivet af Dansk Botanisk Forening $17,1-491$.

Munk A. 1953 - The system of the Pyrenomycetes. Dansk Botanisk Arkiv Udgivet af Dansk Botanisk Forening 15(2), 1-163.

Nag Raj TR. 1977 - Ypsilonia, Acanthotheciella, and Kazulia gen. nov. Canadian Journal of Botany 55, 1599-1622.

Najafzadeh MJ, Badali H, Illnait-Zaragozi MT, de Hoog GS et al. 2010b - In vitro activities of eight antifungal drugs against 55 clinical isolates of Fonsecaea. Antimicrob Agents Chemother 54, 1636-1638.

Najafzadeh MJ, Dolatabadi S, Saradeghi Keisari M, Naseri A et al. 2013 - Detection and identification of opportunistic Exophiala species using the rolling circle amplification of ribosomal internal transcribed spacers. Journal of Microbiological Methods 94, 338-342.

Najafzadeh MJ, Gueidan C, Badali H, Gerrits van den Ende AHG et al. 2009 - Genetic diversity and species delimitation in the opportunistic genus Fonsecaea. Medical Mycology 47, 17-25.

Najafzadeh MJ, Sun J, Vicente VA, Gerrits van den Ende AHG et al. 2010a - Fonsecaea nubica, a new species of agent of human chromoblastomycosis revealed using molecular data. Medical Mycology 48, 800-806.

Najafzadeh MJ, Vicente VA, Sun J, Meis JF et al. 2011 - Fonsecaea multimorphosa sp. nov, a new species of Chaetothyriales isolated from a feline cerebral abscess. Fungal Biologyogy 115, 1066-1076.

Nascimento MMF, Selbmann L, Sharifynia S, Al-Hatmi AM et al. 2016 - Arthrocladium, an unexpected human opportunist in Trichomeriaceae (Chaetothyriales). Fungal Biology 120, 207-218.

Nelson S. 2008 - Sooty molds. Plant Disease 52, 1-6.

Nepel M, Voglmayr H, Schönenberger J, Mayer VE. 2014 - High diversity and low specificity of Chaetothyrialean fungi in carton galleries in a Neotropical ant-plant association. PLoS ONE 9(11), e112756. 
Nylander JAA. 2004 - MrModeltest 2.0. Program distributed by the author. Evolutionary Biology Centre, Uppsala University.

Papendorf MC. 1969 - New South African soil fungi. Transactions of the British Mycological Society 52(3), 483-489.

Park MJ, Shin HD. 2011 - Cladophialophora pucciniophila, a new hyphomycete parasitizing a rust fungus. Mycotaxon 116, 449-456.

Pereira-Carvalho RC, Dornelo-Silva D, Inácio CA, Dianese JC. 2009 - Chaetothyriomyes: a new genus in family Chaetothyriaceae. Mycotaxon 107, 483-488.

Perfect JR, Schell WA.1996 - The new fungal opportunists are coming. Clinical Infectious Diseases 22(Suppl 2), 8112-8118.

Petch T. 1924 - Xylariaceae Zeylanicae. Annals of the Royal Botanic Gardens Peradeniya. 8, 119166.

Petrak F. 1929 - Mykologische Notizen. X. Annales Mycologici 27(5-6), 324-410.

Petrak F. 1953 - Cyclopeltis n. gen., eine neue Gattung der Polystomellaceen. Sydowia 7(5-6), 370-374.

Petrak F. 1914 - Beiträge zur Pilzflora von Mähren und Österr. -Schlesien. Annales Mycologici 12(5), 471-479.

Petrak F, Sydow H. 1934 - Kritisch-systematisch Originaluntersuchungen über Pyrenomyzeten, Sphaeropsideen und Melanconieen. V. Annales Mycologici 32 (1-2), 1-35.

Phookamsak R, Hyde KD, Jeewon R, Bhat DJ et al. 2019 - Fungal Diversityity notes 929-1035: taxonomic and phylogenetic contributions on genera and species of fungi. Fungal diversity 95(1), 1-273.

Pickard A, Kadima T, Carmichael R. 1991 - Chloroperoxidase-aperoxidase with potential. Journal of Industrial Microbiology and Biotechnology 7, 235-242.

Pohlad BR, Reynolds DR. 1974 - Treubiomyces rediscovered. Mycologia 66, 521-524.

Pratibha J, Prabhugaonkar A. 2015 - New record of Thysanorea papuana from India. Mycosphere 6, 480-485.

Pratibha SJ, Gawas P, Hyde KD, Bhat DJ. 2005 - Chalara indica sp. nov. and Sorocybe indicus sp. nov. from India. Cryptogamie Mycologie 26(2), 97-103.

Prenafeta-Boldú FX, Luykx D, Vervoort J, de Bont JA. 2001 - Fungi growing on volatile aromatic hydrocarbons as sole carbon and energy source. In: Proc 5th Int Symp Environm Biotechnol, Kyoto, 253-256.

Prenafeta-Boldú FX, Summerbell R, de Hoog GS. 2006 - Fungi growing on aromatic hydrocarbons: biotechnology's unexpected encounter with biohazard? FEMS Microbiol Reviews 30, 109-130.

Quan Y, Muggia L, Moreno LF, Wang M et al. 2020 - A re-evaluation of the Chaetothyriales using criteria of comparative biology. Fungal Diversity 103, 47-85.

Raghupathi PK, Zupančič J, Brejnrod AD, Jacquiod S et al. 2018 - Microbial diversity and putative opportunistic pathogens in dishwasher biofilm communities. Applied and Environmental Microbiology 84(5), e02755-02717.

Rannala B, Yang Z. 1996 - Probability distribution of molecular evolutionary trees: a new method of phylogenetic inference. Journal of Molecular Evolution 43, 304-311.

Rashmi M, Kushveer JS, Sarma VV. 2019 - A worldwide list of endophytic fungi with notes on ecology and diversity. Mycosphere 10, 798-1079

Réblová M, Hubka V, Thureborn O, Lundberg J et al. 2016 - From the tunnels into the treetops: new lineages of black yeasts from biofilm in the Stockholm metro system and their relatives among ant-associated fungi in the Chaetothyriales. PLOS ONE 11, e0163396.

Réblová M, Untereiner WA, Réblová K. 2013 - Novel evolutionary lineages revealed in the Chaetothyriales (Fungi) based on multigene phylogenetic analyses and comparison of ITS secondary structure. PLoS ONE 8(5), e63547. 
Reeb V, Lutzoni F, Roux C. 2004 - Multilocus phylogenetic circumscription of the lichen-forming fungi family Acarosporaceae and its position within the Ascomycota. Molecular Phylogenetics and Evolution 32, 1036-1060.

Reynolds DR. 1983 - Foliicolous ascomycetee 5: The capnodiaceous clypeate genus Treubiomyces. Mycotaxon 17, 349-360.

Reynolds DR. 1971 - The sooty mould ascomycete genus Limacinula, Mycologia 63, 1173-1209.

Reynolds DR. 1999 - Capnodium citri: the sooty mold fungi comprising the taxon concept. Mycopathologia 148, 141-147.

Riddle FW. 1917 - Pyrenothrix nigra, gen. et sp. nov. Botanical Gazette Crawfordsville. 64(6), 513-515.

Rolland L. 1896 - Aliquot fungi novi vel critici Galliae praecipue meridionalis. Bulletin de la Société Mycologique de France 12, 1-10.

Ruibal C, Gueidan C, Selbmann L, Gorbushina AA et al. 2009 - Phylogeny of rock-inhabiting fungi related to Dothideomycetes. Studies in Mycology 64, 123-133.

Ruibal C, Platas G, Bills GF. 2005 - Isolation and characterization of melanised fungi from limestone formations in Mallorca. Mycological Progress 4, 23-38.

Ruibal C, Platas G, Bills GF. 2008 - High diversity and morphological convergence among melanised fungi from rock formations in the Central Mountain System of Spain. Persoonia 21, 93-110.

Samuels G, Muller E. 1978 - Life-history studies of Brazilian ascomycetes. 3. Melanomma radicans sp. nov. and its Apiosphaeria anamorph. Trematosphaeria perrumpens sp. nov. and Berlesiella fungicola sp. nov. and its Ramichloridium anamorph. Sydowia 31, 142-156.

Santos SAP, Santos C, Silva S, Pinto G et al. 2013 - The effect of sooty mold on fluorescence and gas exchange proper- ties of olive tree. Turkish Journal of Biology 37, 620-628.

Schoch CL, Crous PW, Groenewald JZ, Boehm EWA et al. 2009 - A class-wide phylogenetic assessment of Dothideomycetes. Studies in Mycology 64, 1-15.

Schoch CL, Shoemaker RA, Seifert KA, Hambleton S et al. 2006 - A multigene phylogeny of the Dothideomycetes using four nuclear loci. Mycologia 98, 1041-1052.

Seifert KA, Hughes SJ, Boulay H, Louis-Seize G. 2007 - Taxonomy, nomenclature and phylogeny of three cladosporium-like hyphomycetes, Sorocybe resinae, Seifertia azaleae and the Hormoconis anamorph of Amorphotheca resinae. Studies in Mycology 58, 235-245.

Silvestro D, Michalak I. 2011 - raxmlGUI: a graphical frontend for RAxML. Organisms Diversity \& Evolution 12, 335-337.

Sinclair RC, Morgan-Jones G. 1979 - Notes on hyphomycetes. XXVI. Uncispora harroldii gen. et sp.nov. Mycotaxon 8(1), 140-143.

Sivanesan A. 1984 - The bitunicate ascomycetes and their anamorphs. J. Cramer, Vaduz southern China. Mycotaxon 117(1), 131-135.

Spatafora JW, Mitchell TG, Vilgalys R. 1995 - Analysis of genes coding for small subunit rRNA sequences in studying phylogenetics of Dematiaceous fungal pathogens. Journal of Clinical Microbiology 33, 1322-1326.

Spegazzini C. 1888 - Pugillus II. Anales de la Sociedad Cientifica Argentina 26, 5-74.

Spegazzini, C. 1909 - Mycetes Argentinenses. Series IV. Anales del Museo Nacional de Historia Natural de Buenos Aires 3(12), 257-458.

Spegazzini, C. 1918 - Notas micológicas. Physis Revista de la Sociedad Argentina de Ciencias Naturales 4(17), 281-295.

Staiger B. 2002 - Die Flechtenfamilie Graphidaceae. Studien in Richtung einer natürlicheren Gliederung. Bibliotheca Lichenologica, 85, J. Cramer, Berlin, Stuttgart. 526.

Stamatakis A, Hoover P, Rougemont J. 2008 - A rapid bootstrap algorithm for the RAxML Web Servers. Systematic Biology 57, 758-771.

Stenroos S, Laukka T, Huhtinen S, Döbbeler P et al. 2010 - Multiple origins of symbioses between ascomycetes and bryophytes suggested by a five-gene phylogeny. Cladistics 26, 281-300. 
Sterflinger K, de Hoog GS, Haase G. 1999 - Phylogeny and ecology of meristematic ascomycetes. Studies in Mycology 43, 5-22.

Stevens FL. 1925 - Hawaiian Fungi. Bernice P. Bishop Museum Bulletin 19, 1-189.

Sudhadham M, Dorrestein GM, Prakitsin S, Chaiyarat R et al. 2008 - The neurotropic black yeast Exophiala dermatitidis has a possible origin in the tropical rain forest. Studies in Mycology 61, 145-155.

Sun JZ, Liu XZ, McKenzie EH, Jeewon R et al. 2019 - Fungicolous fungi: terminology, diversity, distribution, evolution, and species checklist. Fungal Diversity 95(1), 337-430.

Sun W, Su L, Yang S, Sun J et al. 2020 - Unveiling the Hidden Diversity of Rock-Inhabiting Fungi: Chaetothyriales from China. Journal of Fungi 6(4, no. 187), 1-37.

Surash S, Tyagi A, de Hoog GS, Zeng JS et al. 2005 - Cerebral haeohyphomycosis caused by Fonsecaea monophora. Medical Mycology 43, 465-472.

Sutton BC, Campbell CK, Goldschmied-Reouven A. 1991 - Pseudomicrodochium fusarioides sp. nov., isolated from human bronchial fluid. Mycopathologia 114, 159-161.

Sydow H, Sydow P. 1917 - Novae fungorum species-XV. Annales Mycologici 15, 143-148.

Sydow H. 1926 - Fungi in intinere costaricensi collecti, pars secunda. Annales Mycologici 24(5-6), 283-426.

Takei H, Goodman JC, Powell SZ. 2007 - Cerebral phaeohyphomycosis caused by Cladophialophora bantiana and Fonsecaea monophora: report of three cases. Clinical Neuropathology 26, 21-27.

Tamura K, Stecher G, Peterson D, Filipski A et al. 2013 - MEGA6: Molecular evolutionary genetics analysis version 6.0. Molecular Biology and Evolution 30, 2725-2729.

Tennakoon DS, Thambugala KM, Jeewon R, Hongsanan S et al. 2019 - Additions to Chaetothyriaceae (Chaetothyriales): Longihyalospora gen. nov. and Ceramothyrium longivolcaniforme, a new host record from decaying leaves of Ficus ampelas. MycoKeys 61, 91-109.

Theissen F, Sydow H. 1917 - Die Gattung Parodiella. Annales Mycologici 15(1), 125-142.

Theissen FSJ. 1913 - Die Gattung Asterina. Abhandlungen der Zoologisch-Botanischen Gesellschaft in Wien 7, 1-130.

Thompson JD, Gibson TJ, Plewniak F, Jeanmougin F et al. 1997 - The CLUSTAL_X windows interface: flexible strategies for multiple sequence alignment aided by quality analysis tools. Nucleic Acids Res 25(24), 4876.

Tian Q, Chomnunti P, Bhat JD, Alias SA et al. 2014 - Towards a natural classification of Dothideomycetes 5: The genera Ascostratum, Chaetoscutula, Ceratocarpia, Cystocoleus, and Colensoniella (Dothideomycetes incertae sedis). Phytotaxa. 176(1), 42-54.

Tian Q, Doilom M, Luo ZL, Chomnunti P et al. 2016 - Introducing Melanoctona tectonae gen. et sp. nov. and Minimelanolocus yunnanensis sp. nov. (Herpotrichiellaceae, Chaetothyriales). Cryptogamie, Mycologie 37, 477-492.

Tintelnot K, von Hunnius P, de Hoog GS, Polak-Wyss A et al. 1995 - Systemic mycosis caused by a new Cladophialophora species. Medical Mycology 33, 349-354.

Trejos A. 1954 - Cladosporium carrionii n. sp. and the problem of cladosporia isolated from chromoblastomycosis. Revista de Biologia Tropical 2, 75-112.

Tsuneda A, Hambleton S, Currah RS. 2011 - The anamorph genus Knufia and its phylogenetically allied species in Coniosporium, Sarcinomyces, and Phaeococcomyces. Botany 89, 523-536.

Tsuneda A, Currah RS. 2004 - Knufia endospora, a new dematiaceous hyphomycete from trembling aspen. Reports of the Tottori Mycological Institute 42, 1-9.

Tsuneda A, Currah RS. 2005 - Pleomorphic conidiogenesis among strains of Knufia cryptophialidica. Canadian Journal of Botany-revue Canadienne De Botanique 83(5), 510 517.

Tsuneda A, Hambleton S, Currah RS. 2011 - The anamorph genus Knufia and its phylogenetically allied species in Coniosporium, Sarcinomyces, and Phaeococcomyces. Botany 89(8), 523536. 
U'Ren JM, Lutzoni F, Miadlkowska J, Arnold AE. 2010 - Community analysis reveals close affinities between endophytic and endolichenic fungi in mosses and lichens. Microbial Ecology 60, 340-353.

Ulloa M, Hanlin RT. 2000 - Illustrated dictionary of mycology. American Phytopathological Society Press, St Paul, Minnesota, 2000, 448.

Untereiner WA, Angus A, Réblová M, Orr MJ 2008 - Systematics of the Phialophora verrucosa complex: new insights from analyses of $\beta$-tubulin, large subunit nuclear rDNA and ITS sequences. This paper is one of a selection of papers published in the Special Issue on Systematics Research. Botany 86, 742-750.

Untereiner WA, Straus NA, Malloch D. 1995 - A molecular-morphotaxonomic approach to the systematics of the Herpotrichiellaceae and allied black yeasts. Mycological Research 99, 897-913.

Untereiner WA 2000 - Capronia and its anamorphs: exploring the value of morphological and molecular characters in the systematics of the Herpotrichellaceae. Studies in Mycology 45, 141-149.

Untereiner WA. 1997 - Taxonomy of selected members of the ascomycete genus Capronia with notes on anamorph-teleomorph connection. Mycologia 89, 120-131.

Untereiner WA, Gueidan C, Orr MJ, Diederich P. 2011 - The phylogenetic position of the lichenicolous ascomycete Capronia peltigerae. Fungal Diversity 49, 225-233.

Untereiner WA, Naveau FA. 1999 - Molecular systematics of the Herpotrichiellaceae with an assessment of the phylogenetic positions of Exophiala dermatitidis and Phialophora americana. Mycologia 91, 67-83.

van Oorschot CA, de Hoog GS, Schüler G. 1982 - A new species of Anthopsis. Antonie Van Leeuwenhoek 48, 61-65.

Verma RK, Kamal. 1987 - Studies on foliicolous ascomycotina-III. Some interesting bitunicati. Indian Phytopathology 40, 410-413.

Vicente VA, Attili-Angelis D, Pie MR, Queiroz-Telles F et al. 2008 - Environmental isolation of black yeast-like fungi involved in human infection. Studies in Mycology 61, 137-144.

Vicente VA, Najafzadeh MJ, Sun J, Gomes RR et al. 2014 - Environmental siblings of black agents of human chromoblastomycosis. Fungal Diversityity 65, 47-63.

von Arx JA, Müller E. 1975 - A re-evaluation of the bitunicate ascomycetes with keys to families and genera. Studies in Mycology 9, 1-159.

von Höhnel FXR. 1910 - Fragmente zur Mykologie: X. Mitteilung (Nr. 468 bis 526). Sitzungsberichte der Kaiserlichen Akademie der Wissenschaften Math. -naturw. Klasse Abt. I, 119, 393-473.

von Höhnel FXR. 1911 - Fragmente zur Mykologie XIII (713): Über Leptosphaeria maculans (Desm.) und Sphaeria lingam Tode. Sitzungsberichte der Kaiserlichen Akademie der Wissenschaften in Wien. (Mathematisch-naturwissenschaftliche Klasse (Abteilung I) 120, 458-463.

von Höhnel FXR. 1918a - Mycologische Fragmente, 272. Über die Hysteriaceen. AnnMycol 16, $145-154$.

von Höhnel FXR. 1918b - Fragmente zur Mykologie. Sitzungsberichten der Kais erliche Akademie der Wissenschaften in WienMathematische-Naturwissenschaftliche Klasse, Abt. 1(127), 329-393.

von Höhnel, FXR. 1909 - Fragmente zur Mykologie: VIII. Mitteilung (Nr. 354 bis 406). Sitzungsberichte der Kaiserlichen Akademie der Wissenschaften. Wien. Mathematisch naturwissenschaftliche Classe. Abteilung 1. 118, 1157-1246.

Vu D, Groenewald M, de Vries M, Gehrmann T et al. 2019 - Large-scale generation and analysis of filamentous fungal DNA barcodes boosts coverage for kingdom fungi and reveals thresholds for fungal species and higher taxon delimitation. Studies in Mycology 92, 135154. 
Wang GN, Yu XD, Dong W, Bhat DJ et al. 2019 - Freshwater hyphomycetes in Eurotiomycetes: a new species of Minimelanolocus and a new collection of Thysanorea papuana (Herpotrichiellaceae). Mycological Progress 18, 511-522.

Wen YM, Rajendran RK, Lin YF, Kirschner R et al. 2016 - Onychomycosis associated with Exophiala oligosperma in Taiwan. Mycopathologia 181(1), 83-88.

Wijayawardene DNN, McKenzie EHC, Hyde KD. 2012 - Towards incorporating anamorphic fungi in a natural classification-checklist and notes for 2011. Mycosphere 3(2), 157-228.

Wijayawardene NN, Crous PW, Kirk PM, Hawksworth DL et al. 2014 - Naming and outline of Dothideomycetes-2014. Fungal Diversity 69, 1-55.

Wijayawardene NN, Hyde KD, Khalil Tawfeeq Al-Ani L, Tedersoo L et al. 2020 - Outline of fungus and fungi-like taxa. Mycosphere 11(1), 1060-1456.

Wijayawardene NN, Hyde KD, Lumbsch HT, Liu JK et al. 2018 - Outline of Ascomycota: 2017. Fungal Diversity 88, 167-263.

Wijayawardene NN, Hyde KD, Rajeshkumar KC, Hawksworth DL et al. 2017 - Notes for generaAscomycota. Fungal Diversity 86, 1-594.

Winka K, Eriksson OE, Bång Å. 1998 - Molecular evidence for recognizing the Chaetothyriales. Mycologia 90, 822-830.

Winter G. 1885 - Pilze-Ascomyceten. In GL Rabenhorst's Kryptogamen-Flora von Deutschland, Oesterreich und der Schweiz 1, 65-528.

Wu WP, Sutton BC. 1995 - Fumagopsis complexa sp. nov., a species with complicated conidial morphology. Mycological Research 99, 1450-1452.

Xi L, Sun J, Lu C, Liu H et al. 2009 - Molecular diversity of Fonsecaea (Chaetothyriales) causing chromoblastomycosis in southern China. Medical Mycology 47, 27-33.

Xia JW, Ma LG, Ruíz RFC, Zhang XG. 2014 - Minimelanolocus bicolorata sp. nov., Paradendryphiopsis elegans sp. nov. and Corynesporella bannaense sp. nov. from southern China. Mycoscience 55(4), 299-307.

Yang H, Chomnumti P, Aryawansa H, Wu H. 2014 - The Genus Phaeosaccardinula (Chaetothyriales) from Yunnan China, introducing two new apecies. Chiang Mai Journal of Science 41, 873-884.

Yang H, Hyde KD, Karunarathna SC, Deng C et al. 2018 - New species of Camptophora and Cyphellophora from China, and first report of sexual morphs for these genera. Phytotaxa 343(2), 149-159.

Yang H, Maharachchikumbura SSN, Deng C, Liu JK. 2021 - Three novel sooty moulds species of Trichomerium from Yunnan, China. Phytotaxa 518(4), 271-280.

Zakharova K, Tesei D, Marzban G, Dijksterhuis J et al. 2013 - Microcolonial Fungi on rocks: a life in constant drought? Mycopathologia 175, 537-547.

Zeng XY, Wen TC, Chomnunti PU, Liu JK et al. 2016 - Ceramothyrium longivolcaniforme sp. nov., a new species of Chaetothyriaceae from northern Thailand. Phytotaxa 267, 51-60.

Zhang K, Fu HB, Zhang XG. 2009 - Taxonomic studies of Minimelanolocus from Yunnan, China. Mycotaxon 109(1), 95-101.

Zhang Y, Crous PW, Schoch CL, Hyde KD. 2012 - Pleosporales. Fungal Diversity 53, 1-221.

Zhang YD, Ma J, Ma LG, Zhang XG. 2010 - A new species of Minimelanolocus from Fujian, China. Mycotaxon 114, 373-376.

Zhaxybayeva O, Gogarten JP. 2002 - Bootstrap, Bayesian probability and maximum likelihood mapping: exploring new tools for comparative genome analyses. BMC Genomics 3(1), 4.

Zhuang JL, Zhu MQ, Zhang R, Yin H et al. 2010 - Phialophora sessilis, a species causing flyspeck signs on bamboo in China. Mycotaxon 113, 405-413. 